JULIA RUIZ DI GIOVANNI

\title{
Cadernos do Outro Mundo: o Fórum Social Mundial em Porto Alegre
}

[VERSÃO CORRIGIDA]

De acordo:

Fernanda Arêas Peixoto

Tese apresentada à Faculdade de Filosofia, Letras e Ciências Humanas da Universidade de São Paulo para obtenção do título de doutora em Antropologia Social.

Orientadora: Profa. Dra. Fernanda Arêas Peixoto. 


\section{Agradecimentos}

À Fundação de Amparo à Pesquisa do Estado de São Paulo pelo apoio que tornou viável a pesquisa e elaboração da tese. À/ao parecerista que acompanhou o desenvolvimento do trabalho muito obrigada pelas sugestões e incentivo.

Ao Programa de Pós-Graduação em Antropologia Social - USP.

À Professora Fernanda Peixoto, orientadora excepcional, que me encorajou a formular, a partir de memórias e inquietações, o projeto de pesquisa que resultou neste trabalho. Obrigada pela confiança, sobretudo, pela amizade, por sua paixão pela troca intelectual, pelo olhar minucioso e generosidade de grande mestre artesã.

Às/aos colegas do Coletivo ASA - Artes, Saberes e Antropologia, é incalculável a importância deste lugar de parceria na construção desta tese e no meu percurso pessoal. Considero um privilégio ter a companhia de vocês, vamos buscando juntos nosso próprio jeito de ser antropólogas/os. A Julia Goyatá e Lorena Avellar, agradecimentos especiais pela leitura antecipada dos capítulos e comentários.

Às/aos colegas do Hybris - Grupo de Estudo e Pesquisa sobre Relações de Poder, Conflitos e Socialidades, grande companhia no atrevimento de pensar a política, a quem pude apresentar os primeiros esboços da tese: muito obrigada pelas sugestões e provocações.

Às professoras Maria Filomena Gregori e Ana Cláudia Marques por sua presença no exame de qualificação e pela contribuição indispensável ao desenvolvimento do projeto.

Às pessoas que este trabalho me permitiu encontrar: obrigada, Hélio Menezes. E àquelas que tive a oportunidade de re-encontrar. A todas aquelas que tinham um "causo" de Fórum para me oferecer. A Alessandra Ceregatti, Ana Paula de Carli, Ana Paula Stock, Fernando Costa, Leandro Anton, Adriano Marcello Santos, Rodrigo Nunes e outros amigos de Porto Alegre - essa tese só existe por causa da nossa conversa, que já dura mais de dez anos. Muitas pessoas importantes na história deste trabalho não pude, de fato, reencontrar: quem sabe tenhamos agora um bom pretexto para retomar a conversa.

À Olivia Gonçalves Janequine, minha comparsa, que fez a revisão dos capítulos.

A Geraldo e Maria Lúcia, por tudo, sempre.

Ao André Mesquita, com quem sigo a viagem pra valer. 


\section{Resumo}

Di Giovanni, Julia Ruiz. Cadernos do Outro Mundo: o Fórum Social Mundial em Porto Alegre. Tese (Doutorado) - Faculdade de Filosofia, Letras e Ciências Humanas, Universidade de São Paulo, São Paulo, 2013.

A presente tese é uma reflexão etnográfica sobre o processo de constituição do Fórum Social Mundial (FSM) como experiência política particular, vinculada à realização de encontros internacionais anuais na cidade de Porto Alegre (RS, Brasil) entre 2001 e 2005, no contexto mais amplo de protestos, encontros e debates associados ao ciclo contestatório dos movimentos antiglobalização ou alter mundialistas. Partindo da análise de textos produzidos a respeito do FSM, de documentos de registro da dinâmica organizativa e de memórias institucionais e pessoais de participação neste processo, este trabalho elabora algumas sínteses a respeito da relação entre a forma de práticas e discursos e os modos de produção dos sentidos das experiências políticas contemporâneas. A tese contribui para reforçar as análises qualitativas e críticas a respeito do fenômeno complexo do Fórum Social Mundial, através de uma perspectiva antropológica que tem como base exercício etnográfico de atenção e descrição dos usos particulares de categorias generalizantes tais como estratégia, metodologia e memória. Voltada para a dimensão processual e expressiva dos modos de fazer e modos de dizer coletivos, este trabalho busca destacar densidade de significados e a historicidade das linguagens da ação política, a partir de inspirações teóricas retiradas das análises das práticas cotidianas, que permitem aproximações entre as antropologias da arte e dos rituais às da política e do conflito.

Palavras-chave: Movimentos Sociais, Antropologia da Política, Fórum Social Mundial 


\begin{abstract}
Di Giovanni, Julia Ruiz. Other World Notebooks: the World Social Forum in Porto Alegre. Thesis (PhD) - Faculty of Philosophy, Letters and Human Sciences, University of São Paulo, São Paulo, 2013.

This thesis is an ethnographic reflection on the process o constitution of th World Social Forum (WSF) a particular political experience, strongly linked to the annual meetings that took place in Porto Alegre (RS, Brasil) between 2001 and 2005, in the context of protests, encounters and debates associated to the contention cycle of the anti or alter globalization movement. Taking as a starting point the analysis of texts written a about the WSF, documents that register its organizational dynamics and both personal and institutional memories of this process, this work develops a few synthesis about the relation between the form os practices and discourses and the production of meaning in contemporary politics experiences. The thesis is a contribution to the qualitative and critical analysis of the complex phenomenon of the World Social Forum, through an

anthropological perspective built on the ethnographic exercise of attention and description of their particular uses of broad categories strategy, methodology and memory. Focused on the processual and expressive dimension of the ways of doing and ways of saying, this work makes an effort to highlight the density of meaning and historicity of the languages of political action, having as a reference the analysis of daily life practices, which allow us to bring together the anthropologies of art and ritual and those of politics and conflict.
\end{abstract}

Keywords: Social Movements, Anthropology of Politics, World Social Forum. 


\section{Sumário}

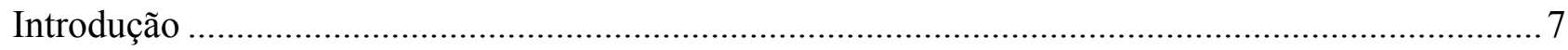

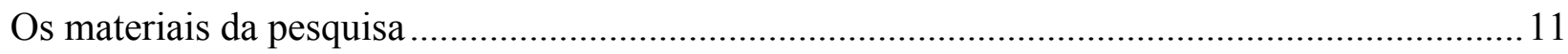

Itinerário teórico

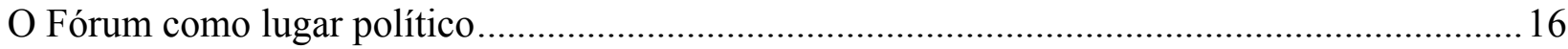

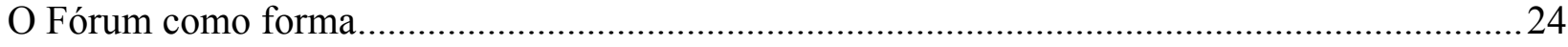

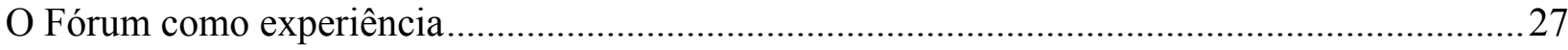

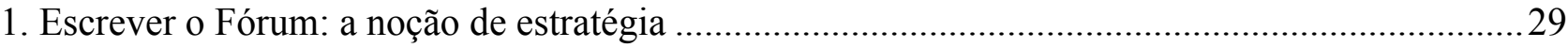

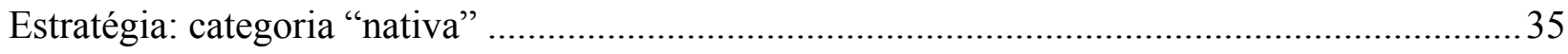

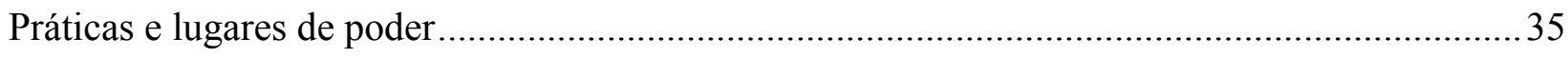

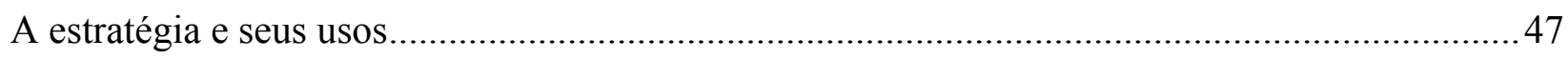

2. Metodologia e arquitetura do espaço Fórum ........................................................................5

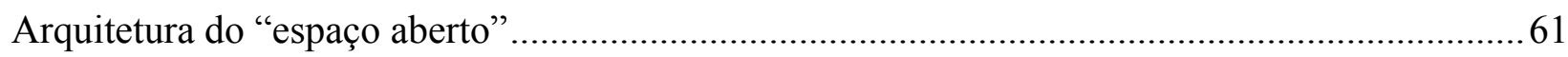

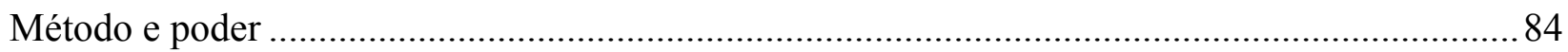

3. As formas da memória no Fórum Social Mundial ...................................................................95

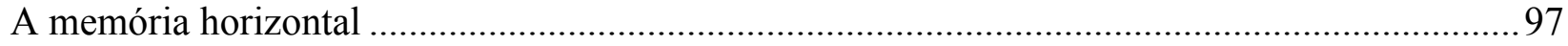

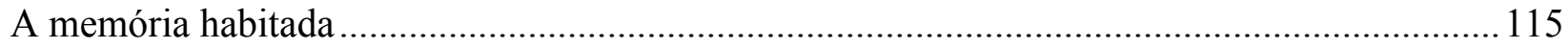

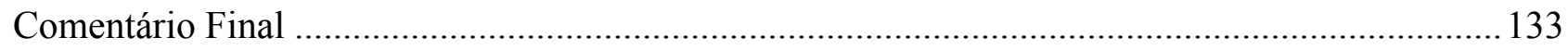

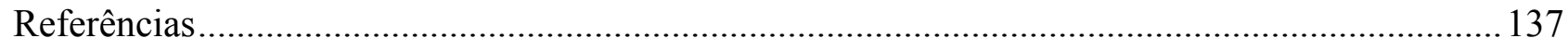

Anexo A: Carta de Princípios do Fórum Social Mundial ........................................................ 147

Anexo B: Temário e esquemas metodológicos do FSM entre 2001 a 2005 ................................ 150

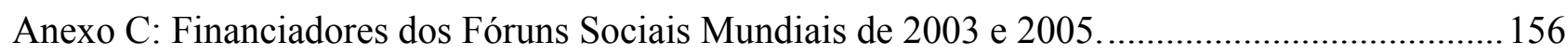

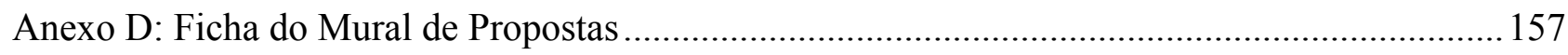

Anexo E: Números do FSM entre 2011 e 2005 .............................................................................. 158 


\section{Introdução}

As condições da possibilidade da história real são, ao mesmo tempo, as condições de seu conhecimento

Reinhardt Koselleck ${ }^{1}$

Escrever sobre o Fórum Social Mundial e fazê-lo no contexto das exigências e responsabilidades implicadas na pesquisa acadêmica em geral e, especificamente, em uma tese de doutorado, não é um desdobramento natural de meu envolvimento militante nesta experiência política. Tendo participado de todas as edições mundiais do FSM entre 2001 e 2005, além de encontros preparatórios e de edições nacionais e regionais (Fóruns Sociais Brasileiro e Argentino, Fórum Social das Américas e do Fórum Social Europeu), escolhi, no mestrado, não me deter em uma reflexão a esse respeito, dedicando-me a estudar protestos de rua que uma abordagem focada nas práticas e táticas - no próprio fluxo conflituoso da performance do protesto - permitia tratar como um universo de ação em larga medida estranho ao contexto dos Fóruns (Di Giovanni, 2012). Enquanto no mestrado o movimento da pesquisa perseguia, na transitoriedade da ação de rua, o caráter criativo e indócil da experiência política, construir um percurso de análise sobre o FSM exigia olhar de frente seus aspectos menos estimulantes, dedicar à litania das racionalidades, institucionalidades e ordenamentos que conferem forma e permanência ao Fórum Social Mundial a mesma atenção entusiasmada que as poéticas astutas do protesto facilmente capturavam. Conduzir a reflexão antropológica para dentro desse contexto foi, assim, um caminho de desnaturalização.

Ouvi falar do Fórum Social Mundial pela primeira vez em meados de 2001, em uma das reuniões de um grupo de discussão sobre movimentos sociais e leituras marxistas organizado por um professor de filosofia da Fundação Armando Álvares Penteado, onde cursava o segundo ano do bacharelado em Rádio e Televisão. Fui a Porto Alegre em 2001, a convite de um jornalista, membro da ATTAC - rede internacional de origem francesa que realiza campanhas pelo controle cidadão das transações financeiras internacionais - que participara de uma das reuniões do grupo apresentando as linhas gerais daquilo que deveria ser um grande encontro internacional de esquerda, reunindo os intelectuais e representantes de organizações e movimentos protagonistas das notícias que acompanhávamos e discutíamos com grande interesse, sobre manifestações anti-neoliberais nos cinco continentes. Embora mal reconhecesse os nomes da lista de palestrantes famosos confirmados, concordei que se tratava de um encontro de extrema importância, e me dispus a buscar aí um envolvimento político que jamais experimentara antes. Assim, a origem da minha trajetória

\footnotetext{
${ }^{1}$ Koselleck, 2011, p. 308.
} 
como ativista teve lugar em algum ponto da mesma trama de relações, estruturas operacionais, políticas, semânticas e afetivas que começavam a dar forma ao próprio Fórum.

Viajei à capital gaúcha pela primeira vez em janeiro de 2001, um mês antes do evento, acompanhando como voluntária a transferência do escritório da organização geral do Fórum do prédio da Ação Educativa na Rua General Jardim, em São Paulo, para um conjunto de salas com ar condicionado localizada no Centro de Eventos da Pontifícia Universidade Católica do Rio Grande do Sul (PUCRS). Uma de minhas tarefas era alimentar a seção "Biblioteca das Alternativas" do site do Fórum $^{2}$ com os textos apresentados durante as atividades do FSM por representantes e intelectuais, ou textos que estes mesmos convidados indicassem como referência para os temas de debate daquela primeira edição ${ }^{3}$. No entanto, o trabalho ia muito além do acompanhamento do site. Entre os voluntários brasileiros e estrangeiros que trabalharam no escritório, as incumbências eram repartidas segundo critérios variáveis, fundados no grau de confiança que os funcionários e membros do Comitê Organizador recém constituído depositassem em nós, em nossa agilidade na solução de problemas, na fluência em diferentes idiomas e na desenvoltura com que éramos capazes de dar informações e decifrar demandas através dos telefones que tocavam ininterruptamente.

Tendo visto muito pouco do que acontecia fora dos escritórios da PUCRS, regressei a São Paulo e passei a fazer parte do pequeno núcleo paulistano da ATTAC, de que participavam também membros da organização do Fórum. No mesmo ano, depois de, através da rede, ter tomado parte dos protestos contra o G8 em Gênova, Italia (Di Giovanni, 2012), estive envolvida na preparação do segundo Fórum Social Mundial. Incentivada pelos companheiros da ATTAC, passei a participar ativamente das reuniões itinerantes de preparação do Acampamento Intercontinental de Juventude, de que participava um público ativista muito diferente do que conhecera no ano anterior. Havia ali sobretudo uma forte identificação àquilo que chamávamos de uma "nova geração política", independente da faixa etária e para além da noção de "juventude", ligada à sensibilidade e às formas organizativas que os protestos antiglobalização tinham tornado visíveis (Nunes, 2005, p. 288; Di Giovanni, 2002; 2003). Voltei a Porto Alegre em janeiro de 2002 por conta própria, para colaborar com as discussões gerais do Acampamento e com a organização de uma série de pequenos encontros que recebeu o nome de Laboratório Intergalactika (Baba, 2003; Nunes, 2005). No mesmo ano, meses após o segundo FSM, passei a trabalhar na Sempreviva Organização Feminista (SOF), organização que então sediava a coordenação em nível nacional e latino-americano da Marcha Mundial das Mulheres (MMM) - um movimento feminista internacional. Foi como militante da Marcha Mundial das Mulheres que participei dos Fóruns Sociais Mundiais de 2003 a 2005. Nestes

\footnotetext{
${ }^{2}$ Ver http://www.forumsocialmundial.com.br.

${ }^{3}$ Ver anexo B: temas do FSM entre 2001 e 2005.
} 
três anos, trabalhei na realização de atividades incluídas na programação pela própria MMM e outros movimentos aliados, na articulação de encontros e oficinas realizados em Porto Alegre durante os eventos do FSM, acompanhando as reuniões preparatórias gerais do Fórum e da Assembleia Mundial de Movimentos Sociais, e assumindo tarefas de representação e apoio junto a instâncias organizativas do FSM, entre elas o Comitê Organizador Brasileiro de 2005 e algumas reuniões do Conselho Internacional.

Além de corresponder ao percurso de envolvimento pessoal com o Fórum, o período de 2001 a 2005, pode ser descrito como um ciclo inaugural do FSM, marcado por alguns aspectos organizativos determinantes. Em primeiro lugar, é o período em que o Fórum se caracteriza por encontros mundiais anuais, ao mesmo tempo em que se multiplicam "fóruns sociais" em escala regional ou local. Em segundo lugar, durante estes anos, a realização dos encontros mundiais permanece vinculada à cidade de Porto Alegre. Embora a edição de 2004 tenha sido realizada em Mumbai, na Índia, o FSM volta à capital gaúcha em 2005, já marcado por mudanças e questionamento, ligados em particular à questão da periodicidade dos eventos mundiais e aos temas da "mundialização" e da necessidade de "enraizamento" do FSM. Mais tarde, tais questões passam a orientar a opção dos organizadores pela alternância entre eventos globais unificados e rodadas de Fóruns temáticos e regionais espalhados pelo mundo. Após 2005, além de os eventos mundiais passarem a ser bienais, intercalados com atividades descentralizadas, sua localização passa a ser rotativa, embora vinculada a cidades do "Sul" geopolítico: Belém do Pará, no Brasil, ; Bamako, no Mali; e Dacar, no Senegal. Este primeiro ciclo do FSM, seu período de formação coincidente com a época de minha própria formação como militante, define um assim recorte temporal (2001- 2005) e geográfico (a cidade de Porto Alegre) ao objeto da tese. Esta coincidência entre o momento de constituição do Fórum e o ciclo de meu engajamento como ativista, tem implicações do ponto de vista metodológico e teórico. Se podemos afirmar que o fato de ter tomado parte no FSM neste período oferece as vantagens de uma perspectiva de observação situada dentro do processo analisado, é preciso afirmar também que essa participação observante não garante a priori a qualidade e a condição crítica da análise. Encontrar um lugar de pesquisadora é o primeiro problema do trabalho.

A seleção de materiais na farta literatura publicada e no enorme volume de documentos sobre o Fórum disponíveis na Internet - relatórios de atividades, textos analíticos, documentação de reuniões e debates, boletins informativos, notas de imprensa, relatos, e-mails - é um desafio adicional que se impõem imediatamente à pesquisa. Além de um grande fluxo de materiais sobre o Fórum produzidos e circulados entre 2001 e 2005, a produção continua após esse intervalo, multiplicando ilimitadamente as fontes disponíveis. Mais do que possibilitar a coleta de materiais e 
informações (encontráveis online em grande quantidade e variedade), as novas viagens a Porto Alegre, bem como a participação na décima primeira edição mundial do evento em Dacar, Senegal, em 2011, empreendidas como viagens a campo e possibilitando reencontros com os espaços e pessoas conhecidos durante o período de envolvimento com o Fórum, foram um recurso fundamental para que se pudesse constituir um novo ponto de vista sobre as experiências vividas e formular questões sobre o próprio caráter abundante, excessivo e em grande medida repetitivo da fontes encontradas nos meios virtuais e bibliográficos. Nestas viagens, sobretudo, o próprio tempo que separa os momentos do engajamento imediato e os da pesquisa torna-se sensível: as transformações materiais e imateriais com que somos confrontados (no espaço urbano, nas redes de relações humanas, nos discursos ou nas fisionomias) transformam também nossos modos de olhar e construir análises.

Percorrendo as notas da primeira viagem realizada a Porto Alegre durante o projeto, em janeiro de 2010, encontro, por exemplo, a seguinte anotação de uma conversa com um dos arquitetos envolvidos no planejamento do Acampamento da Juventude e, em 2005, um dos responsáveis pelo desenho de distribuição das atividades do Fórum na cidade: "Vir ao FSM já teve um sentido de peregrinação". A ideia é familiar à minha memória de militante, provavelmente reforçada pela expressão atribuída ao jornal Le Monde Diplomatique (e difundida com certo tom pejorativo na imprensa brasileira), que define a cidade de Porto Alegre dos tempos do Fórum, até 2004 sob o governo do Partido dos Trabalhadores, como a "Meca" da esquerda internacional. Em diálogo com esta imagem, uma passagem de Clifford Geertz em Obras e Vidas (2002, p.22 ), anotada no caderno durante a mesma viagem, afirma que também a etnografia pode ter um caráter de peregrinação, mas é, além disso, uma forma de cartografia.

Em outro ponto do caderno de campo, refletindo sobre estas figuras, me pergunto: participei então do FSM até 2005 como peregrina e agora volto como antropóloga para realizar uma espécie de cartografia? Hoje a tese que concluo inclui cartografias: em vários momentos aborda mapas das edições do Fórum em Porto Alegre, como marcas (reais ou imaginadas) da experiência nos participantes e na cidade, ou como documentos gráficos de relações silenciosas de sentido e de poder. Mas também a experiência militante, a do FSM em particular, tem seus momentos de cartografia: fazer política é também produzir mapeamentos. Lembro claramente que a admiração por alguns ativistas muito presentes no período da minha entrada como militante no Fórum Social Mundial, entre 2001 e 2005, era inspirada pela habilidade que essas pessoas tinham de traçar amplos mapas mentais, bastante detalhados, referenciando segundo origens, filiações ideológicas, relações de aliança, propósitos políticos ou "estilo", a vasta diversidade de movimentos, grupos, organizações, coletivos e personalidades que compunham o dito movimento antiglobalização. Os 
documentos de metodologia e os temários complexos de cada uma das edições do FSM podem ser lidos em si mesmos como instrumentos de mapeamento e de navegação no universo de assuntos, consensos e impasses políticos em um determinado momento histórico. Não parece exagerado afirmar que também os militantes, meus companheiros e "nativos", são, nesse sentido, colegas cartógrafos: produtores de espacialidades, de mapas do mundo em que vivem e de outros mundos sonhados.

Ambos os sentidos atribuídos por Geertz à atividade do etnógrafo, assimiláveis a uma descrição da experiência militante do FSM, parecem aqui colaborar mais com a aproximação entre as posições de observador e participante do que com a exigência que as separa. Isso não significa que os dois pontos de vista sejam coincidentes, indica apenas que essa proximidade deve ser tratada com o devido respeito. Se, como etnógrafa, pretendo produzir mapas do Fórum Social Mundial, será necessário antes dedicar um olhar atento aos mapas - mentais, gráficos ou afetivos - que outros sujeitos em campo parecem produzir continuamente. E se empreender uma etnografia é também uma forma de peregrinação - um itinerário de engajamento - a etnógrafa no Fórum Social Mundial também caminha sobre as pegadas de muitos outros peregrinos, inclusive sobre marcas antigas de suas própria passagem.

Os procedimentos da cartografia e da peregrinação dizem respeito à relação entre formas de engajamento (político) e a produção de conhecimento, tema subjacente dos exercícios de análise que busco desenvolver sobre o Fórum Social Mundial. As aproximações que tais imagens sugerem reforçam, sobretudo, a compreensão de que a produção de conhecimentos não poderá aqui ser entendida como privilégio do pesquisador: a própria escolha dos materiais a serem tratados nesta tese - em sua maioria discursos de natureza analítica - indicam que o problema do exercícios de interpretação que me arrisco a desenvolver não é desbravar um território ermo, mas habitar um campo intelectual já bastante populoso. Neste sentido, a perspectiva da pesquisadora não pode definir-se apenas pela autoridade etnográfica de quem “esteve lá”: tantos estiveram lá, como escrever então algo novo e relevante sobre um "lugar comum"? A pesquisa, assim, é a proposta de uma nova viagem que, mesmo percorrendo um itinerário antigo, busca a formulação de perguntas diferentes (não necessariamente maiores ou melhores) daquelas que a viagem militante permitia formular.

\section{Os materiais da pesquisa}

Um volume impressionante de discursos sobre o Fórum Social Mundial, cuja proliferação nos meios eletrônicos é praticamente diária, foi produzido de 2001 a 2005 e continua sendo aumentado a cada ano, em um circuito que envolve desde os informes internos às organizações 
integrantes do processo até declarações e análises difundidas em nível internacional por intelectuais de grande visibilidade, como José Saramago ou Immanuel Wallerstein. A viabilidade desta pesquisa teve como desafio fundamental uma série de escolhas com relação à análise deste material, posto sempre em diálogo com as experiências de participação que ampliam exponencialmente as possibilidades de leitura dos diferentes argumentos. Não se trata de esgotar a análise desta produção, mas de oferecer um percurso possível de leituras, pautadas pelo interesse em problematizar algumas categorias empregadas para qualificar a singularidade da experiência política no FSM, buscando entender assim as transformações do sentidos da ação coletiva nesse contexto.

Como busquei esclarecer, esta pesquisa compreende uma confrontação sistemática com a tarefa de fazer de uma experiência militante, da qual há alguns anos tomei distância, um campo etnográfico. Como escrever sobre o Fórum Social Mundial de que fui e possivelmente ainda sou parte? Levando em conta o desafio, o primeiro movimento da pesquisa procurou conjugar justamente os dois verbos centrais desta pergunta: escrever e fazer parte. A matéria textual não apenas é o corpo mais visível do Fórum, mas tem um papel fundamental em sua definição como lugar político, como forma e como experiência. Assim, o maior volume do material de análise é fundamentalmente composto de textos. O conjunto inicial de fontes primárias é composto por documentos hoje disponíveis no website ${ }^{4}$ criado pela secretaria do FSM, mantida em São Paulo até 2012. Este conjunto inclui documentos aprovados no âmbito do Conselho Internacional - entre eles a Carta de Princípios do FSM -, documentos sobre regras e funcionamento, informes de reuniões e balanços internos, e uma série de documentos ditos metodológicos, referidos às edições anuais do Fórum Social Mundial, em que se definem os temas do encontro, a tipologia das atividades a serem inscritas pelas organizações participantes, os mecanismos de agrupamento e as condições de realização destas atividades. Os documentos registram mudanças ao longo dos anos, com a complexificação dos temas e estruturas de inscrição e a relação complexa entre as premissas da Carta de Princípios e as tensões de sua tradução em um método organizativo que crescentemente constitui o Fórum Social Mundial e define seus limites.

$\mathrm{O}$ exame dessa primeira seleção de fontes obriga à mobilização de um conjunto mais amplo de referências. Além dos documentos internos, os discursos que escrevem o Fórum e são um modo fundamental pelo qual pessoas e coletivos fazem parte dele têm também como formas privilegiadas as análises e balanços. Em torno dos processos de realização dos primeiros eventos do FSM em Porto Alegre, gravita um conjunto de textos e artigos heterogêneos, elaborados por ativistas, representantes e intelectuais envolvidos nos encontros do Fórum Social Mundial. Ainda que muitas

\footnotetext{
${ }^{4}$ Ver em http:// www.forumsocialmundial.org.
} 
vezes tenham como assunto mais evidente os eventos anuais, estes documentos são sempre referidos ao Fórum como um processo de caráter internacional e permanente, fornecendo muitas indicações sobre os modos de construção de uma totalidade que ultrapassa os eventos individuais e lhes confere sentidos comuns. As fontes analisadas incluem análises e balanços produzidos entre 2001 e 2005, muitos deles disponíveis na seção Biblioteca das Alternativas do site oficial do Fórum Social Mundial, a mesma que ajudei a alimentar como voluntária em 2001, sob a rubrica "Balanços dos eventos globais do Fórum Social Mundial”, distribuídos em páginas dedicadas a cada ano 5 . Também foram incluídos entre as fontes alguns textos de balanço posteriores a 2005, encontrados na mesma fonte, cujos conteúdos oferecem elementos adicionais para a análise de processos e noções consolidados no primeiro ciclo de formação do Fórum. Publicados em sites independentes da organização do FSM e em várias coletâneas de artigos, estes textos não oficiais são de fundamental importância para a apreensão dos sentidos e tensões que permeiam os documentos produzidos pelas instâncias organizativas.

A análise de iniciativas de memória e arquivamento relacionadas ao Fórum Social Mundial abarca ainda outros tipos de documentos, como mapas e fotografias, além de algumas entrevistas e muitas conversas realizadas com antigos participantes em Porto Alegre e São Paulo durante o período da pesquisa. A investigação de formas institucionais e pessoais de registro e arquivamento sobre o FSM nos colocou diante de projetos incompletos, coleções que em grande parte foram dispersas ou jamais chegaram a se constituir, o que demandou um tipo de abordagem independente da disponibilidade de acervos. Como veremos no terceiro capítulo, o sentido da memória extrapola as práticas de arquivamento: há muito mais memórias do Fórum, que possuem dimensão imaterial, que estão contidas explicita ou implicitamente na experiência cotidiana, nas ações e discursos, nas marcas deixadas pela realização do Fórum em alguns espaços urbanos de Porto Alegre. Não sendo possível uma descrição sistemática do conteúdo de acervos disponíveis e organizados, a ideia é refletir a partir das narrativas sobre coisas lembradas e esquecidas, em que as constelações da memória são mobilizadas e reinventadas quase sempre no calor de acontecimentos presentes.

\section{Itinerário teórico}

A literatura existente sobre o Fórum Social Mundial é marcadamente uma literatura militante. Como veremos no primeiro capítulo, a produção de análises sobre o FSM participa da sua produção enquanto experiência, articula seu sentido de unidade e define sua especificidade política.

\footnotetext{
${ }^{5}$ A expressão "eventos globais" é usado para diferenciar os encontros mundiais das edições regionais (por exemplo: Fórum Social Europeu ou Fórum Social das Américas) e temáticas (por exemplo: Fórum Mundial da Educação ou Fórum Social das Migrações), que se multiplicaram ao longo destes anos e são consideradas parte do "processo FSM".
} 
Uma imersão nesta literatura engajada, tomada como fonte fundamental da pesquisa, foi indispensável para entender mais a fundo os modos de articulação desta linguagem, tarefa indispensável da pesquisa. Ao mesmo tempo, o desafio de encontrar um lugar de pesquisadora passou necessariamente pela identificação de uma bibliografia analítica específica com que dialogar. São raros os textos em que encontramos um esforço interpretativo crítico à carga de autocelebração contida nos documentos oficiais. Faltam descrições dos eventos e trabalhos que se detenham na problematização das características atribuídas ao Fórum por seus organizadores e divulgadores mais entusiastas. Trabalhos como os Janet Conway, Thomas Ponniah, Boaventura de Souza Santos e José Correia Leite, que articulam abordagens muito diferentes entre si, têm em comum o fato de dificilmente levarem adiante questionamentos sobre a natureza dos próprios discursos produzidos sobre o Fórum: tendem a tomar como ponto de partida afirmações que mereceriam ser expostas à problematização, à luz do próprio envolvimento dos dos autores na experiência do FSM.

$\mathrm{Na}$ literatura específica, os autores que inspiraram nossa abordagem são aqueles que, também engajados politicamente no processo, parecem ter buscado o caminho de desnaturalizar afirmações e conceitos estruturantes dos discursos que produzem o Fórum enquanto tal: "espaço", "horizontalidade”, “diálogo", entre outros. Merecem ser mencionados, entre os trabalhos realizados no Brasil, a dissertação de Diego Araújo Azzi (2008), publicada recentemente pela Hucitec, e o trabalho de Odaci L. Coradini (2009). Entre as publicações no exterior, o número cinco da Revista Ephemera: Theory and Politics in Organization (2009), dedicado ao FSM, organizado por Böhm, Reyes e Sullivan, reúne algumas das leituras que se mostraram mais frutíferas na elaboração deste trabalho, entes as quais se destacam as reflexões de April Biccum, Steffen Böhm, Colin Wright e Rodrigo Nunes. O que estas análises têm em comum, embora diferentes entre si do ponto de vista dos temas específicos tratados e das abordagens escolhidas, é o esforço de seus autores em confrontar as expectativas e perspectivas conceituais que os levaram engajar-se na construção política do Fórum - assumindo papéis organizativos, promovendo iniciativas, mas também produzindo análises sobre ele - e a experiência direta de sua participação. A insistência dos autores em incorporar as contradições desta experiência ao trabalho analítico, sem minimiza-las, parece-me uma virtude fundamental.

Referências teóricas mais gerais mostraram-se também relevantes no percurso de "retorno" ao Fórum Social Mundial, não para oferecer modelos, mas para inspirar sobretudo questionamentos e interpretações. Em primeiro lugar, as reflexões de Michel de Certeau (1980) sobre as noções de tática e estratégia em $A$ Invenção do Cotidiano e sobre a ação política articulada como linguagem em La Prise de Parole (1968), foram importantes na formulação do projeto de pesquisa e 
acompanharam o desenvolvimento da tese. No plano de observação proposto por De Certeau, a política é uma dimensão da experiência em que ação, enunciação, sentido e memória encontram-se sempre fundidos. Trabalhando ao mesmo tempo com a análise de práticas e discursos, emprego neste trabalho uma expressão frequente de De Certeau, "modo de fazer", de modo a tentar abranger tanto a ação quanto as formas de linguagem, os "modos de dizer", e colocá-las em um mesmo nível de complexidade simbólica, para assim buscar compreender seu papel na constituição do Fórum Social Mundial como lugar político, como forma e como experiência.

Também o trabalho de Michael Herzfeld, sobre a complexidade das ideologias do Estado, Cultural Intimacy (1997), forneceu inspiração teórica para nossa abordagem do Fórum Social Mundial, em que pretendemos observar momentos em que relações de poder são articuladas também como linguagens de poder. É a analogia com a propriedade da linguagem reconhecida por Jakobson como "função poética" que permite a Herzfeld revelar a mobilidade de significados e intenções implicadas em uma forma política ou ideológica aparentemente estática, ou tornar visível que a espontaneidade e originalidade da ação política passam pelo domínio de códigos de poder surpreendentemente estáveis (Herzfeld, 1997, p. 41).

A "função poética" da ação social e política, como o "modo" que De Certeau identifica nas artes do fazer quotidiano, é uma formulação teórica que busca enfocar a articulação entre regras e seus usos, entre grandes sistemas explicativos e pequenas práticas quotidianas, entre estruturas e ação desdobrada no tempo. Estratégia, metodologia e memória, como motivos condutores em uma obra musical ou literária, são noções associadas a modos de fazer e modos de dizer que se repetem, fórmulas que indicam a presença de uma estrutura de sentidos subjacente aos discursos e práticas. Ao mesmo tempo, cada vez que aparecem, misturadas aos interesses, pontos de vista e expectativas de diferentes sujeitos em situações particulares, trazem significados novos: observando-as, podemos perceber como as fórmulas aparentemente coerentes dos discursos militante têm sua integridade posta em risco quanto mais são empregadas. Graças aos usos cotidianos, conflitantes e disparatados, as estruturas de sentido estão sempre sujeitas a rupturas, contradições e distorções.

Os termos que servem de eixo para cada um dos capítulos - estratégia, metodologia e memória - cumpriram um papel fundamental na busca de uma aproximação livre e crítica, mas que de alguma forma fizesse justiça à experiência de engajamento em que todos os conhecimentos (meus e de outros) sobre o campo, apesar da passagem do tempo, estão enraizados. Cada capítulo toma como assunto uma palavra que é ao mesmo tempo conceito analítico - termo que faz parte de um sistema de conhecimento - e uma categoria em uso na experiência política dos Fóruns: são temas generalizantes, guias formais para a análise, mas também noções "procedentes do mundo da vida" (Koselleck, 2011, p. 307), feitas de particularidades e transformações. Podemos dizer que 
estes termos nos oferecem chaves para decifrar relações e situações concretas justamente porque, como propõe Reinhardt Koselleck, outra das inspirações importantes desse trabalho, "são constitutivas ao mesmo tempo da história e de seu conhecimento" (1979, p. 308).

Como já sugeri, a distância que possibilita a construção de um olhar analítico distinto do olhar de dentro é, antes de mais nada, uma distância temporal. A relação entre como se vive o tempo da história e como se produz seu conhecimento torna-se um problema que atravessa escolhas metodológicas e inspirações teóricas da tese e uma questão subjacente aos três capítulos analíticos que a compõem. Estratégia, metodologia e memória, tal como se apresentam, marcadas por seus usos contingentes no contexto do FSM, são noções entrelaçadas à dimensão do tempo: dão a ver e produzem relações entre passado, presente e futuro.

\section{O Fórum como lugar político}

Os discursos sobre aquilo que o Fórum deve ser e para que serve são o material do primeiro capítulo da tese, articulam-se em torno a uma proposição estratégica: construir o FSM como lugar de poder e saber e como lugar político particular no contexto de um "movimento global" mais amplo, colocando novos atores em destaque no debate anti ou alter-globalização. Como propõe Koselleck, a análise racional que encontramos em textos programáticos e analíticos faz parte da constituição de horizontes de expectativas (2011, p. 310): em sua natureza estratégica, a tarefa de "escrever o Fórum", é um trabalho de antecipação do futuro. Os discursos que tomamos como material fundamental do primeiro capítulo, em particular aqueles produzidos entre 2000 e 2002, falam do Fórum no futuro: não se referem a experiências realizadas e conhecidas, mas ao domínio do "ainda não", daquilo que se espera, deseja, ou teme que ele seja.

Por volta do ano 2000, o cenário político internacional estava marcado pela presença insistente de manifestantes contrários à ordem mundial neoliberal que se consolidara após o fim dos acordos de Bretton Woods. À articulação de campanhas através de redes internacionais, como as campanhas contra a implementação da Área de Livre Comércio das Américas (ALCA) e o Acordo Multilateral de Investimentos, somavam-se protestos de rua cada vez mais espetaculares. As jornadas de protesto contra a Organização Mundial do Comércio (OMC) realizadas em Seattle, Estados Unidos, em novembro de 1999, foram reconhecidas como "a mais importante manifestação que a sociedade norteamericana conheceu desde os anos de manifestações contra a guerra do Vietnã" (Seoane e Taddei, 2001, p. 113). Em 2000, uma multitudinária manifestação contra a reunião anual do Fundo Monetário Internacional (FMI) e o Banco Mundial em Praga, na República Tcheca, conquista as manchetes de jornais em todo o mundo. 
Onde quer que autoridades se reunissem para falar de globalização, os manifestantes “antiglobalização" apareciam exibindo bandeiras e faixas, desafiando nuvens de gás lacrimogênio, gritando palavras de ordem, atirando pedras, deitando-se ou dançando no meio da rua (Di Giovanni, 2012). Graças a esses protestos, um imaginário político particular começou a ganhar corpo: a própria a ideia da inevitabilidade das formas da economia global era contestada por formas de organização percebidas como "novas", não tradicionais, que produziam um quadro de ação distinto das agendas de partidos e os sindicatos, convencionalmente inscritas no contexto particular do Estado-nação. Emergia um "movimento global" que tinha a escala planetária como base, "simultaneamente demandando e produzindo uma esfera política transnacional para seus discursos e práticas” (Nunes, 2005, p. 279).

"Estamos vencendo" - dizia uma pichação em um muro durante os protestos de Seattle, difundida por uma fotografia: uma rede de ativismo decentralizada e sem nome exibia nas ruas vitalidade, disposição em driblar forças policiais e habilidade de roubar a cena em um "mundo globalizado", confrontando as autoridades da ordem mundial. Como seguir vencendo era o problema. Como encontrar formulações coletivas sobre o significado político dessas vitórias? Como capitalizar as energias das dezenas de milhares de manifestantes que saiam às ruas contra as corporações transnacionais, a Organização Mundial do Comércio ou o Fundo Monetário Internacional? Como dar o próximo passo na crescente confrontação que a força daquelas manifestações finalmente permitia imaginar? Diante destas questões, começa a ser concebido um outro tipo de evento: não voltado para o protesto, mas para a reflexão, um encontro de intelectuais e movimentos de todo o planeta que oferecesse oportunidade de elaboração, no plano das ideias e conceitos, da rebeldia antiglobalização que se tornara visível nos protestos de rua.

O Fórum Social Mundial foi concebido neste espírito, como um evento simultâneo e antagônico à realização anual do Fórum Econômico Mundial em Davos, Suíça. ${ }^{6}$ Tratava-se assim de uma espécie de contra evento, como os protestos de Seattle e Praga. No entanto, a iniciativa do encontro partia da avaliação de que os protestos eram insuficientes do ponto de vista político, falhando em comunicar a um imaginado público global a existência de proposições alternativas ao neoliberalismo. "Manifestar-se contra", até então, parecia um modo efetivo de expor as injustiças do sistema mundial capitalista, mas, segundo Teivo Teivanem, "ainda que vários grupos participantes tenham afirmações programáticas para futuros alternativos, a forma como esses eventos foram encenados não foi muito favorável a chamar a atenção pública para esses futuros”.

\footnotetext{
6 Encontro anual que reúne os principais líderes empresarais, polítcos, intelectuais, "empreendedores sociais" e jornalistas para discutir as agendas da economia global, cuja base organizacional é uma fundação suíça financiada por mais de mil empresas de alcance transnacional.
} 
Parecia o momento propício para transpor o limite do "anti" e desenhar para o movimento global um horizonte construtivo: não se trata apenas de afirmar que "o mundo não é uma mercadoria", era preciso sintetizar positivamente o sentimento de agitação social em torno de uma proposição - “um outro mundo é possível".

No contexto de um suposto consenso sobre a necessidade da passagem a um momento mais propositivo na história deste "movimento global", localiza-se a narrativa mais difundida sobre a origem do Fórum Social Mundial (FSM). A ideia original do evento e a definição de suas principais características teriam sido fruto de uma conversa entre Oded Grajew, coordenador do CIVES (Associação Brasileira de Empresários pela Cidadania), Francisco Whitaker, da Comissão Brasileira de Justiça e Paz (CBJP) - órgão vinculado à Congregação Nacional de Bispos do Brasil (CNBB), voltado a temas de justiça social e desenvolvimento - e Bernard Cassen, diretor do jornal Le Monde Diplomatique e presidente da já mencionada rede ATTAC. Durante um encontro dos três em Paris, em fevereiro de 2000, imagina-se um evento anti-neoliberal a ser realizado em um país do "Sul Global". Tendo em mente uma contraposição ao Fórum Econômico Mundial de Davos, onde a globalização era tema de debates "a serviço do capital”, propunha-se um outro encontro "de dimensão mundial e com a participação de todas as organizações que vinham se articulando nos processos de massa, voltado para o social - o Fórum Social Mundial” (Whitaker, 2004). O Fórum Social deveria ser realizado nas mesmas datas do Fórum Econômico, para que reforçasse assim a oposição simbólica e midiática entre os dois eventos (Teivanen, 2009).

Segundo o relato de Whitaker, teria partido de Bernard Cassen a ideia de sediá-lo e Porto Alegre, capital de um estado "que vem se tornando conhecido por suas experiências democráticas e de luta contra o neoliberalismo" (Whitaker, 2004). A perspectiva de Porto Alegre como uma cidade de esquerda e anti-neoliberal vinha da notoriedade das experiências implementadas na cidade pelos governos do Partido dos Trabalhadores (PT), que se manteve na prefeitura por 16 anos, entre 1988 e 2004. Entre as iniciativas mais conhecidas, o programa de Orçamento Participativo - sistema de conselhos eleitos e assembleias abertas para a definição de prioridades e monitoramento da aplicação de parte do orçamento municipal - ganhara fama internacional como um mecanismo inovador de democratização, participação popular e transparência. Em 1998, Olívio Dutra, primeiro prefeito petista de Porto Alegre, elegera-se governador do Estado do Rio Grande do Sul (19992002), de modo que um evento na cidade poderia buscar o apoio não apenas da prefeitura, mas do governo estadual.

O núcleo de organizações brasileiras dispostas a assumir a iniciativa forma-se não em Porto Alegre, mas em São Paulo, através de um acordo de cooperação entre a representação nacional da ATTAC, a Associação Brasileira de ONGs (ABONG), as ONGs Ibase (Instituto Brasileiro de 
Análises Sócio Econômicas) e CIVES, a Rede Social de Justiça e Direitos Humanos, a Comissão Brasileira de Justiça e Paz da CNBB, a Central Única dos Trabalhadores (CUT) e o Movimento dos Trabalhadores Sem Terra (MST) - entidades que constituem a partir deste momento o Comitê Organizador Brasileiro do Fórum Social Mundial. Uma comitiva destas entidades viaja a Porto Alegre para uma exitosa consulta ao Governador Olívio Dutra e ao então prefeito Raul Pont (19972000) sobre as possibilidades de apoio ao evento, propondo como princípio a condição de independência da coordenação política da iniciativa, a ser conduzida não pelo Estado, mas pelas entidades da sociedade civil (Whitaker, 2004).

Desde o primeiro evento FSM, realizado com apoio massivo da Prefeitura e do Estado e a cooperação de redes de ONGs e agências internacionais de financiamento, a responsabilidade das decisões políticas e logísticas passam pelo Comitê Organizador. Além de criar condições materiais para a realização dos Fóruns, o Comitê torna-se o centro mobilizador da enorme rede de organizações, de natureza tão variada quanto possível, interessadas em produzir um evento de oposição ao Fórum Econômico Mundial, a propor e realizar atividades nas cidade de Porto Alegre, durante quatro ou cinco dias coincidentes com a realização do Fórum de Davos. Desde o início, foram convocados a participar do encontro todos os coletivos, de qualquer parte do mundo, que manifestassem oposição ao neoliberalismo e fossem capazes de enviar representantes à capital gaúcha e garantir o desenvolvimento de atividades com recursos próprios no âmbito de um vasto programa comum.

Na primeira edição do Fórum, o público de 20 mil pessoas já supera as expectativas dos organizadores: esperava-se inicialmente algo em torno de cinco mil pessoas. Em 2005, quando o Fórum, já em seu quinto ano de existência, foi realizado pela quarta vez em Porto Alegre, 155 mil participantes foram cadastrados, sendo 35 mil integrantes do Acampamento da Juventude e 6.823 comunicadores. Neste que foi o último ano em que foi realizado em Porto Alegre, o evento reuniu cerca de 6.872 organizações de 151 países e 2.500 atividades diferentes: segundo estimativas da Brigada Militar, 500 mil pessoas circularam pela área destinada às atividades do Fórum, (FSM, 2005).

Odaci L. Coradini discute a participação no FSM a partir de um estudo baseado em entrevistas e na aplicação de questionários, promovida pelo IBASE (2005), no último ano de realização do Fórum em Porto Alegre (Coradini, 2009). Os limites da investigação frente à magnitude e à complexidade do evento, são destacados de saída pelo autor, que registra ainda os riscos do celebracionismo que ronda o estudo desde o trabalho de coleta de informações. Para Coradini, parece forçada toda identificação de um denominador comum - orientação política que unifique o amplo leque de organizadores e público - para além de uma oposição generalizada à 
globalização (cuja definição varia muito). É a partir de distinções internas ao grupo de promotores do Fórum que o autor concebe as linhas gerais de mapeamento dos participantes do Fórum:

alguns polos destacam-se, quanto às modalidades de organização e de princípios de legitimação [...] guardadas as proporções, são basicamente esses mesmos polos que dividem e opõem o conjunto de participantes, embora evidentemente com pesos diversos (Coradini, 2009, p.224).

Segundo estes critérios de polarização relativos a padrões de organização e de legitimação, Coradini identifica na composição do Fórum Social Mundial as presenças de organizações sindicais "de esquerda" (aspas do autor); ONGs de âmbito local e nacional também à "esquerda"; dos ditos movimentos sociais, aqui definidos pela referência ao MST, como aglutinações de outras organizações menores e locais, mobilizadas em nome da população "pobre" (aspas do autor) ou fora do mercado de trabalho; organizações "com base no recorte de gênero"; associações de empresários em torno do tema da cidadania (é o caso do CIVES); organizações estudantis; e organizações diretamente vinculadas à Igreja Católica (Coradini, 2009, p. 225-226). Em um polo quase residual, o autor agrega as organizações de muito peso na promoção do FSM, mas sem maior inserção no Brasil, como seria o caso da ATTAC.

Atravessado por esses e outros conteúdos de "identidade" e polaridades, o Comitê Organizador foi responsável, pelo menos nos primeiros anos do Fórum, pela realização, de forma concertada, de um núcleo de atividades de debate e apresentação de visões políticas que oferecesse uma espécie diagnóstico geral do mundo e das alternativas práticas ou teóricas gestadas em oposição à ordem neoliberal da globalização. Na preparação do FSM 2001, as organizações internacionais que desempenhavam papel de mobilização e apoio político à realização do evento foram incluídas em uma instância provisória chamada de Comitê Internacional Consultivo. Em grande medida, a realização de debates de maior destaque, assim como a participação de intelectuais e lideranças políticas de reconhecimento internacional, dependia das redes de contato e relações diretas dos membros do Comitê e das organizações que eles representavam. Ao Comitê Organizador, inicialmente de forma autônoma e mais tarde através de consultas formais às organizações participantes, cabia a formulação de um conjunto de temas ou "eixos", em torno dos quais todos os participantes deveriam propor suas atividades.

Como aponta Nunes (2005), todos os atores brasileiros envolvidos no lançamento do Fórum Social Mundial tinham relações de longa duração com o Partido dos Trabalhadores (PT). O maior partido de esquerda da América Latina fora desde o final dos anos 1970, um dos mais importantes "guarda-chuvas" da política brasileira: “especialmente no caso da CUT e o MST, mais do que 
simplesmente 'relacionados', foram talhados na mesma madeira, vieram do mesmo caldo de cultura de que nasceu o PT no início dos anos 1980" (Nunes, 2005, p. 280). A presença do partido no Fórum não pode ser tratada, como afirma o autor, como algum tipo de "infiltração": mais do que como um fator de interferência externa, essa presença é uma contingência da política nacional e local. Não se trata de um ator oculto manipulando as decisões sobre temas e convidados, mas um fator fundamental do cenário político em que tais decisões têm lugar:

a linha condutora comum entre os atores relacionados ao PT - o governo do Estado e alguns membros do Comitê Organizador - não eram ordens emanadas de algum ponto, mas um entendimento compartilhado sobre quais outros atores deveriam ser incluídos e qual deveria ser a cara do Fórum (Nunes, 2005, p. 281).

O contexto das atividades da sociedade civil relacionadas a eventos oficiais promovidos pelas próprias instituições internacionais, em particular no âmbito do sistema das Nações Unidas, é outro dos elementos importantes desse cenário. A formação de um primeiro Comitê Internacional de Apoio ao Fórum é marcada por essa contingência: ele é constituído oficialmente na ocasião das atividades da sociedade civil paralelas às sessões especiais da Assembleia Geral das Nações Unidas sobre o desenvolvimento social, a chamada "Copenhagen +5 ", em Genebra, Suíssa, de que participa uma comitiva do Comitê Organizador acompanhada pelo então vice-governador do rio Grande do Sul, Miguel Rosseto (Whitaker, 2004, p. 2; Azzi, 2007, p. 112). Também importantes na articulação de organizações e redes internacionais - européias, em particular - em torno da realização do primeiro Fórum teriam sido as reuniões paralelas ao Fórum Econômico Mundial de Davos, onde circulavam propostas de consolidação de uma estrutura de colaboração, reflexão e articulação política permanente entre as organizações e redes envolvidas em ações nacionais e internacionais contra as políticas neoliberais (Whitaker, 2004, p. 1-2; Tarrow, 2005, p. 130).

Como afirma Sidney Tarrow, "encontros paralelos" da sociedade civil, organizados para coincidir com reuniões internacionais oficiais, eram comuns nos anos 1980 e 1990: 
na medida em que a Guerra Fria arrefece e a prática de realização de cúpulas internacionais oficiais cresce geometricamente, as ONGs e movimentos sociais começaram a voltar sua atenção para a decisões tomadas durante essas reuniões, organizando encontros paralelos $\left(2005\right.$, p. 129) ${ }^{7}$.

Ao final da década de 1990, tendem a se intensificar "contra-cúpulas", também simultâneas aos eventos oficiais, mas mais abertamente questionadoras da legitimidade das instituições internacionais e claramente ligadas a práticas de confronto, tanto dentro dos espaços oficiais abertos à participação disciplinada da sociedade, quanto em manifestações conflitivas do lado de fora desses espaços: Seattle, em 1999, representaria o auge desta tendência ao acirramento das confrontações.

Tarrow define o surgimento do Fórum Social Mundial como uma fusão oportuna entre o modelo da "cúpula paralela", mais comum para as organizações dos países da Europa e dos Estados Unidos, e os encuentros internacionais que já faziam parte da cultura de ONGs e diferentes movimentos sociais na América Latina. Comum no movimento estudantil e entre as organizações feministas do continente, por exemplo, a prática do encontro internacional também ganhara novo significado na década de 1990, com a realização, em 1996, do primeiro Encuentro Intergalactico Contra el Neoliberalismo y por la Humanidad, em Chiapas, no México. Trata-se da região que o levante do Exército Zapatista de Libertação Nacional tornara "um importante locus de inspiração e intercâmbio político" (Nunes, 2005, p. 278), onde que os grupos e redes dos países do norte, que começavam a mobilizar-se para boicotar as corporações transnacionais e bater de frente com as instituições financeiras internacionais, encontravam-se com o imaginário das lutas populares latinoamericanas renovado pela poética do discurso zapatista.

As reuniões paralelas, contra-cúpulas e encuentros eram formas familiares e referências para os brasileiros que tiveram a iniciativa de promover o primeiro Fórum e para os governos que se interessaram em apoiá-la (Tarrow, 2005, p. 130). Eram formas que expressavam concepções sobre a política por vezes contraditórias. Por um lado, um evento internacional anti-neoliberal não poderia, naquele momento, ser concebido sem incorporar a linguagem organizativa e as expectativas que

\footnotetext{
${ }^{7}$ No caso das conferências do sistema ONU, por exemplo, essa movimentação adquire uma dimensão fundamental durante os anos 1990, na medida em que as próprias conferências tornam-se regulares e passam a ser consideradas parte de um sistema global de "governança", constituindo um espaço de construção de acordos e objetivos comuns entre estados. Segundo Constanza Tabbush (2005), a regularidade e a visibilidade crescente destas conferências as tornava atraentes para a organizações e movimentos interessados em influenciar os debates sobre políticas internacionais em temas como direitos humanos, meio ambiente, desenvolvimento sustentável, direitos das mulheres, racismo e novas tecnologias. Ao mesmo tempo, a presença da sociedade era importante para aumentar a legitimidade das próprias organizações internacionais e dos governos envolvidos nas negociações nesses espaços. Este interesse significou, por exemplo, que o apoio financeiro às ONGs crescesse significativamente entre os anos 1995 e 2000, período de ascensão do dito movimento antiglobalização mas também de proliferação das conferências globais das Nações Unidas sobre os temas mencionados: "uma das características da conferências globais dos anos 1990 foi o encorajamento sem precedentes da participação da organizações do sociedade civil” (Tabbush, 2005, p. 6).
} 
marcavam a ascensão de um movimento nas ruas, protagonizado por ativistas jovens: a crítica às formas organizativas hierárquicas vistas como típicas de uma esquerda composta fundamentalmente por partidos políticos e sindicatos; as estruturas ditas horizontais e descentralizadas de tomada de decisão; a organização em rede de grupos política e ideologicamente autônomos e a resistência à institucionalização. Como veremos no Capítulo I, a produção de análises e balanços concomitante à realização dos primeiros Fóruns Sociais Mundiais é fortemente marcada por um discurso de valorização disso que se apresentava na época como uma "nova forma de fazer política". Como síntese dessa forma "nova", surge para definir o caráter do FSM a noção de "espaço aberto", ou "espaço de diálogo", opostas ao sentido programático ou de dirigismo que pareciam estar contidos na noção de "movimento".

Por outro lado, a concepção do Fórum como "espaço", é também fundada em mecanismos racionalizados de controle e hierarquização - tais como a criação de uma Carta de Princípios, a concentração das decisões e gestão de conflitos políticos nas mãos de um Comitê Organizador e a consolidação de um emaranhado crescente de regras de participação - que tornavam o evento viável do ponto de vista das relações institucionais, interessante para os investimentos do Estado e das Agências de Cooperação Internacional ${ }^{8}$. Cada evento sucessivo expande a variedade de grupos participantes (e o número de participantes individuais), mas traz também um grau mais elevado de institucionalização (Tarrow, 2005, p. 131), bem como a consolidação de práticas não raro semelhantes a formas ditas "velhas", mecanismos de direcionamento e acumulação de poder conhecidos das ONGs, bem como da esquerda partidária e sindical. Através do Fórum, espaço de menos confronto, mais estruturado e favorável do que os protesto de rua a gerar imagens amigáveis através da imprensa internacional, "muitos grupos e organizações que nos anos anteriores tiveram um papel secundário puderam vir à frente outra vez e dar seu toque particular à alter-globalização" (Nunes, 2005a, p. 305). Esse "vir a frente", em grande medida, toma a forma de discursos cujo assunto é o próprio Fórum Social Mundial, discursos que constroem o Fórum como sinônimo de um novo horizonte de ação política.

De maneira geral, esse Fórum imaginado e escrito como locus da política do futuro, combina ao contexto de práticas organizativas do universo institucional de relações entre organizações sociais e Estado - que caracterizam tanto o contexto das "cúpulas" internacionais paralelas quanto o quadro nacional de atuação das organizações brasileiras que assumem responsabilidades pela realização dos eventos - à linguagem da auto-organização, da radicalização democrática e da reflexividade, fortalecida durante o ciclo de protestos do final dos anos 1990.

\footnotetext{
${ }^{8}$ Ver no anexo $\mathrm{C}$ a tabela de financiadores.
} 


\section{O Fórum como forma}

Após a realização do primeiro encontro em 2001, a estrutura organizativa formada pelo Comitê Organizador Brasileiro e seu escritório/secretaria sediado em São Paulo, começa a se expandir. É criado Conselho Internacional composto por dezenas de organizações e movimentos, tomados como representativos de lutas anti-neoliberais, que passa a responder pela direção política do Fórum Social Mundial. O Conselho Internacional, do ponto de vista de sua composição e do seu lugar no processo de tomada de decisões, incorporava e ampliava o Comitê Internacional Consultivo criado para apoiar a realização do primeiro evento. Em sua nova forma, o Conselho Internacional torna-se uma espécie de âmbito permanente do FSM e referência internacional a que passa a se remeter o Comitê Organizador Brasileiro. O documento "Entenda a estrutura do Fórum Social Mundial", divulgado em dezembro de 2002, informa:

As questões políticas gerais, a discussão sobre os rumos do FSM e as metodologias dos eventos anuais são debatidas e encaminhadas no âmbito do Conselho Internacional, composto por cerca de 130 organizações, movimentos e redes cuja ação tenha abrangência internacional ou representatividade reconhecida (Fórum Social Mundial, 2002b).

É o Conselho Internacional que aprova, neste momento, a Carta de Princípios (Anexo A), documento que passa a representar a totalidade do Fórum Social Mundial como um processo colaborativo e torna-se uma referência constante de todas as decisões e procedimentos internos daí em diante. Os conteúdos da Carta, organizados em 14 pontos - sínteses formuladas em um contexto particular - foram construídas, em sua primeira versão, pelo conjunto de organizações brasileiras que compunha até a conclusão do primeiro evento, a única instância organizativa reconhecida, capaz de emitir discursos em nome do Fórum Social e definir suas regras. O emprego do termo "metodologias" no documento que define as atribuições do Conselho é importante: a linguagem do método será, daí em diante, o principal registro da atuação desta instância Internacional, enquanto o poder do Comitê Organizador permanece ligado ao âmbito da infra-estrutura.

A aprovação da Carta pode ser considerada o primeiro momento em que o FSM é tratado como uma forma política específica. Mais do que estabelecer propósitos, trata-se de princípios de um modelo organizativo ainda bastante indefinido: a Carta é uma matriz de representações políticas a que devem corresponder algumas determinações formais. Muitos pontos estipulados na Carta tratam de uma série de "questões de ordem": a definição do tipo de atividades a ser realizadas no quadro FSM, definido como lugar de debates, reflexões e circulação de propostas concebidas como alternativas "a um processo de globalização comandado pelas corporações transnacionais, pelos governos e instituições transnacionais a serviço de seus interesses"; a prevenção de disputas 
internas de poder sintetizadas na definição do Fórum como "espaço aberto" às diversidades; e o estímulo ao reconhecimento mútuo e construção de iniciativas comuns entre as "entidades e movimentos" que dele participam (Carta de Princípios, 2001).

Em outros documentos oficiais, como o "Guia de Princípios para a realização de eventos FSM" (2008), está presente um esforço semelhante de definir o Fórum tendo como referência uma série de procedimentos: ele é sintetizado politicamente como uma espécie de manual prático, algo determinado por uma ordem de instruções e tarefas, mais do que por fórmulas ideológicas (essas quando aparecem, tendem ao minimalismo $)^{9}$. As concepções do FSM como forma e como método, fundadas na mesma perspectiva, ganham importância nos primeiros anos de sua existência e continuam em operação depois de 2005, ao ponto de resultar no Guia mencionado acima, criado em 2008 como complemento à Carta de Princípios. O sociólogo Boaventura de Souza Santos incorpora essa abordagem ao dar o título de "Manual de Uso" a sua análise do Fórum publicada em 2005 (Santos, 2005).

Os discursos em que o Fórum Social é definido como um forma metodológica, objeto do segundo capítulo da tese, dialogam com a centralidade que as formas práticas adquirem no contexto do movimento antiglobalização, assumindo, mais do que as formulações de demandas ou objetivos, o papel de dar sentido à organização política. Como destaquei anteriormente, a análise de sentidos políticos neste contexto demanda um trabalho de descrição etnográfica das formas da ação, uma vez que nos discursos dos próprios militantes, o coração do que Janet Conway chama de ethos antiglobalização (2008, p. 3), algo de que o FSM é herdeiro, é inseparável de modelos práticos de organização, comunicação, confrontação e tomada de decisões. Mesmo os ideais e conceitos mais abstratos - como "criatividade", "resistência" e "rede" - chegam a ser definidos, nesta perspectiva

\footnotetext{
${ }^{9}$ Como acontece em um dos verbetes do inventário lúdico "Astúcias e técnicas das lutas anti-capitalistas", de Morjane Baba (um pseudônimo), publicado na França em 2003, um Fórum Social pode ser descrito como uma rotina: "Imensa feira da contestação, com estandes e barracas de lanche, bem como uma grande concentração de camisetas com a efígie de Che e venda aos gritos de jornais raros com títulos de outros tempos. Parte-se dali frequentemente com os bolsos cheios de panfletos - os mais longos são os melhores - os cadernos cheios de notas sobre múltiplos assuntos e a caderneta de endereços cheia de novos amigos ao redor do globo. Nos Fóruns Sociais se encontram reunidos sindicatos, associações, ONGs, partidos, mas também indivíduos e grupos informais. Todos apresentam suas atividades e participam dos debates e oficinas. Aí encontramos diferentes tipos de lugares de reunião, diferentes tipos de uso da palavra [prise de parole] (conferências, debates, discussões mais horizontais, reuniões políticas), um acampamento ou aldeia, espaços auto-gestionados, espaços mais oficiais, hotéis de luxo tomados de militantes. Um Fórum Social Mundial acontece todos os anos (os três primeiros aconteceram e Porto Alegre, o de 2004 acontecerá na Índia), ao qual se somam fóruns sociais continentais, regionais, temáticos, da minha cidade, do meu bairro" (Baba, 2003, p. 104-105). Em tom ingênuo e irônico, Morjane Baba define o Fórum descrevendo o que se faz "dentro" dele, como uma sequência de procedimentos.
} 
pragmática, como formas utilitárias: "ferramentas"10 que não apenas servem como meios subordinados a um fim, mas podem ser empunhadas como símbolos de identidade, constituindo a uma linguagem de diferenciação entre grupos (Di Giovanni, 2012).

O Fórum Social Mundial, pode ser entendido como uma forma utilitária pela qual se pretende diferenciá-lo politicamente de experiências organizativas anteriores e contemporâneas. O segundo capítulo desta tese, ao mesmo tempo em que busca apresentar a evolução de uma morfologia do Fórum, busca construir uma distância com relação aos enunciados que restringem a análise da "forma" ao registro utilitário. No contexto dos estudos recentes sobre os movimentos sociais, Daniel Cefaï, no extenso trabalho "Pourquoi se mobilise-t-on?" (2009), faz considerações a serem levadas em conta antes de tomar o utilitarismo das definições militantes ao pé da letra: o que são "ferramentas"? A metáfora da caixa de ferramentas, carregada de suposições de função e eficiência, segundo Cefaï, empregada com frequência nos movimentos, é incorporada em larga medida pelas análises baseadas em teorias da ação racional, da gestão de recursos, repertórios e estruturas de oportunidade. Ela é problemática, afirma o autor, porque silencia o fato de que um modo de ação, uma prática, mais do que um instrumento, é um operador de uma gramática política: define certos modos de visibilidade, de espacialidade e temporalidade (Cefaï, 2007, p. 254). Além de investigar que relações uma "ferramenta" é capaz de produzir, é preciso perguntar pelas relações e ordens em que se inscrevem sua criação e seus usos.

No Capítulo 2 veremos como, no caso Fórum Social Mundial, sua realização enquanto "metodologia", independente de qualquer valor de eficácia, é o que define sua unidade política enquanto processo e define o pertencimento de certos atores a uma mesma totalidade política: o processo-Fórum. É preciso portanto, levar à sério a proposição do Fórum-como-método, levar adiante sua descrição como forma utilitária, mas duvidar das relações aparentemente simples entre "recursos" e "oportunidades" que aparecem para explicar, por exemplo, todo o universo de decisões e escolhas que determinam como, quando, onde e com quem um Fórum Social acontece. Sob a rubrica da forma e, mais especificamente, da metodologia, são definidos os temas a serem tratados durante os eventos, as modalidades de inscrição de participantes, a tipologia das atividades, os critérios para sua inscrição na programação do encontro e a distribuição da programação no tempo e no espaço. Fazer parte do Fórum Social Mundial significa adotar uma série de procedimentos, neste sentido, adotar um método que abrange, em sua escala mais ampla, as noções abstratas de respeito à

\footnotetext{
${ }^{10}$ No livreto "Caja de Herramientas", publicado em Buenos Aires por um coletivo de ativistas formado a partir de atividade realizadas no contexto do segundo Fórum Social Mundial, tais conceitos são apresentados como peças de uma caixa de ferramentas: "Pensamos que su productividad será mayor em tanto que sean tomados simplemente como recursos (herramientas) que podrán luego ser utilizados y recreados libremente por aquellos que se sientan llamados a hacerlo", afirma o texto de apresentação do Colectivo Intergalactika para sua Caja de Herramientas para la Militancia Anticapitalista (Intergalactika, 2003, p. 4).
} 
diversidade e disposição colaborativa, mas também, em escala reduzida, uma série de regras práticas que começam com o ato de inscrição. A metodologia, também chamada de "arquitetura" do Fórum, não é uma ferramenta neutra: ela estabelece classes de participação que correspondem a critérios de legitimidade e representação. O sentidos políticos do Fórum Social Mundial tendem a se desdobrar em regras ditas metodológicas, regras que dão forma a esta experiência política.

\section{O Fórum como experiência}

Não por acaso a memória é o tema do último capítulo desta tese. Se muitas vezes a memória está identificada à ideia de acúmulo (de dados, documentos, resultados), ela remete também ao que ficou faltando, lacunas e frustrações, que dizem tanto sobre uma experiência política quanto a coleção de coisas que possam ser dispostas em catálogos ou somadas ao "saldo positivo" de um balanço. No universo denso das coisas vividas há muito do que escapa ao esforço de racionalização, contido nas análises que se escreve sobre o Fórum, e do que não obedece a regras de uso que pretendem definir seu sentido. Uma incalculável parte das atividades realizadas em Porto Alegre durante os dias dos Fóruns, bem como as pessoas que ali circulam, não passam pelo processo formal de inscrição ou programação, nem são lembradas em informes e balanços. As proporções de cada um dos eventos ultrapassam e muito as capacidades explicativas de seus participantes e organizadores. Em uma reunião de balanço após a edição de 2002, quando o Fórum ainda não atingira nem a metade dos números de participação a que chegaria em 2005, alguém já afirmava sua dificuldade em dar conta daquela experiência: "o Fórum ultrapassou a escala humana".

$\mathrm{Na}$ dimensão da memória, assunto do último capítulo da tese, buscamos recuperar a escala humana no exercício de pensar o Fórum Social Mundial tal como ele se inscreve no passado, incorporado a objetos, registros de acontecimentos, elaborações e vestígios que possam ser lembrados e articulados. Esta perspectiva é particularmente importante para evitar que o Fórum seja reduzido a um modelo esquemático - como relação histórica de causa e efeito ou como uma espécie de estrutura funcional vazia, a ser preenchida por "conteúdos". A indagação sobre como o Fórum inscreve-se nas experiências individual e coletiva é uma questão fundamental para que se possa descrevê-lo e analisá-lo como fenômeno da ordem da cultura.

Tratar o FSM como fenômeno da cultura não é equivalente a afirmar, sem maiores consequências, que o Fórum Social Mundial define-se como uma "nova cultura política" (Gribowsky, 2006). Aqui, pelo menos, a noção de "cultura política" não parece corresponder em nada à noção antropológica de cultura: ela é antes a ideia de "cultura" como um conjunto suficientemente restrito de recursos, uma reedição da metáfora da "caixa de ferramentas". Neste sentido, aparentemente, um objeto se torna "cultural" na medida em que cabe em uma caixa, 
separado de seus usos improváveis e sobretudo considerado independente das relações que lhe dão sentido: perde seu sentido político. É necessária alguma vigilância para que o destaque dado à dimensão cultural no contexto de movimentos sociais não termine recebendo o papel inglório de simplesmente designar uma desvinculação entre a ação social e seus efeitos de poder ou simplesmente sua falência em termos utilitários. O "cultural" tornar-se-ia assim uma espécie de vazio cognitivo, habitado por coisas efervescentes e aparentemente intratáveis em termos da teoria social, aprisionadas no mistério das vivências do corpo, que nunca se misturam com o pensamento analítico e as decisões de natureza estratégica. Sobre os acontecimentos de maio de 1968 na França, Michel de Certeau formula perguntas ainda atuais: a que serve dizer que uma ação considerada politicamente ineficaz é uma "revolução cultural”? A que serve, quando parece impossível descrever "resultados", enumerar os "aspectos culturais" de um processo como quem inventaria ferramentas antigas, bonitas e fora de uso? (1968, p.42). A dimensão cultural no sentido antropológico é uma perspectiva de imbricação fundamental entre práticas, poder e produção de sentido como constitutiva do social.

Nossa reflexão final, sobre um Fórum que já é passado - mesmo que ainda exista como lugar e como forma - busca trazer ao primeiro plano uma série de resíduos de uma experiência vivida e que esta tese, de certa forma, permitirá compartilhar. Curiosamente, aqui, o passado não é feito de uma coleção de objetos desbotados: ele é vivo, habitado pelo sentido pleno do Fórum Social Mundial como o lugar onde é preciso estar agora. Um sentido político, sem dúvida, carregado pela intensidade física e intelectualmente sensível do momento em que se deseja e pode mudar o mundo - o momento em que nos percebemos participantes ativos de sua transformação. 


\section{Escrever o Fórum: a noção de estratégia}

um poder é a preliminar deste saber, e não apenas seu efeito ou atributo. Ele possibilita suas características e as comanda. Ele se produz aí.

Michel de Certeau ${ }^{11}$

O Fórum Social Mundial não apenas é um tipo de evento ou uma série de encontros localizados e intermitentes, mas envolve uma atividade contínua, em que pessoas e grupos se encontram permanentemente engajados. A jornalista Naomi Klein registra uma imagem ao final do primeiro encontro realizado em Porto Alegre, em 2001:

Um fato talvez não incomum no encerramento de um encontro assim me pareceu digno de nota: um casal no avião, que estava nos assentos da fileira ao lado da minha, ainda usava seus crachás do Fórum. Era como se eles quisessem permanecer naquele mundo sonhado, ainda que imperfeito, por um tempo um pouco mais longo, antes de se separarem nas conexões para Newark, Paris, Cidade do México, engolidos por um enxame de apressados homens de negócios, sacolas Gucci dos free-shops e notícias da CNN sobre as cotações das bolsas de valores (Klein, 2002, p. 269).

Talvez não seja realmente um fato incomum. Acredito ter visto cenas semelhantes na época de minha participação nos encontros. Também não é improvável que outros participantes tenham conservado seus antigos crachás, por mais de dez anos, entre outras lembranças de militância ou no meio desses papéis que se guarda teimosamente em uma gaveta sem saber ao certo o porquê de sua importância. Muitas palavras frequentes nos dias dos eventos - como "entidades", "convergência", "articulação", "espaço", "sistematização", "aglutinação" - certamente continuam a ser usadas fora dele. Por um lado, o Fórum Social Mundial é feito de convergências temporárias, por outro, consiste em um emaranhado de relações, formas semânticas e pertencimentos que sobrevivem após as cerimônias e marchas de encerramento. Da mesma maneira, para além da presença nos eventos, muitos participantes e organizadores, desde 2001, veem e enunciam o Fórum Social Mundial como lócus permanente de sua atividade política. Para usar a imagem que nos oferece Klein, alguns participantes demoram a tirar seus crachás, outros não parecem interessados em fazê-lo jamais.

É difícil encontrar análises que definam o FSM como um "ator político". Como veremos a seguir, evita-se fazê-lo parecer demasiado monolítico e busca-se distingui-lo do estilo dos partidos políticos e movimentos. Entretanto, é comum que os mesmos autores que enfatizam seu caráter

\footnotetext{
${ }^{11}$ De Certeau, 1980, p. 60.
} 
múltiplo e polifônico escrevam sobre ele como um verdadeiro sujeito, dotado de corpo, alma e vontade - "o Fórum opta", "o Fórum precisa" (Teivanen, 2009, p. 94). Embora constituído por diferentes atores e modos de engajamento, não necessariamente coerentes entre si, e ainda que a literatura enfatize insistentemente sua natureza plural, esse sentido de unidade do Fórum nunca desaparece por completo. Este modo objetivado de se referir ao FSM, que o separa dos sujeitos que lhe dão vida, parece fundamental para que pessoas e coletivos possam experimentá-lo e falar dele como algo que faz sentido em suas ações e discursos.

Após a realização do primeiro encontro em 2001, é constituído um Conselho Internacional do Fórum Social Mundial, composto por dezenas de organizações e movimentos sociais, tidos como representativos de lutas anti-neoliberais. São as mesmas organizações que aderem à convocatória do primeiro Fórum e que, de alguma forma, declaram-se dispostas a dedicar uma parcela de seus recursos humanos, econômicos e políticos para consolidar algum tipo de rede de colaborações em torno do evento e de seu lema - "Outro mundo é possível”. Incluídas no Conselho estão as oito organizações brasileiras integrantes do Comitê Organizador, responsáveis pela convocação do FSM e pela viabilização do primeiro evento em Porto Alegre. Com uma composição fixa, mas passível de expansão, e legitimado por princípios de representatividade temática e geográfica, o Conselho Internacional aparece como lugar legítimo das reflexões e decisões consideradas "políticas" e "estratégicas" que devem conferir sentido à colaboração entre as organizações ali reunidas. É o Conselho Internacional que aprova, naquele momento, a Carta de Princípios, documento que define o Fórum Social Mundial como processo colaborativo e passa a orientar seus procedimentos daí em diante. Segundo o texto da Carta,

O Fórum Social Mundial de Porto Alegre foi um evento localizado no tempo e no espaço. A partir de agora, na certeza proclamada em Porto Alegre de que "um outro mundo é possível", ele se torna um processo permanente de busca e construção de alternativas, que não se reduz aos eventos em que se apoie (Carta de Princípios, 2001).

Enquanto instância de tomada de decisões, o Conselho recém-formado também distingue seu funcionamento permanente dos "eventos em que se apoie". As discussões e decisões do Conselho devem balizar as escolhas práticas implicadas na preparação de eventos futuros, mas fica claro que o caráter político e reflexivo de suas atividades referem-se a algo maior. Ao mesmo tempo em que definem fronteiras e orientam procedimentos, a Carta de Princípios e a vigência do Conselho afirmam uma unidade do Fórum Social Mundial que ultrapassa o sentido do evento anual. Assim, a disposição para a continuidade dos engajamentos produzidos no primeiro encontro tornase condição necessária de integração “a ser respeitada por tod@s que queiram participar desse 
processo e organizar novas edições do Fórum Social Mundial” (Idem). A noção de "processo permanente", estabelecida na Carta, torna-se um princípio sobreposto às unidades de sua realização como evento anual (FSM 2001, FSM 2002, 2003 e assim por diante). É nesse sentido, antes de qualquer outro, que se torna possível (e desejável, segundo os organizadores) referir-se ao "Fórum" no singular, e não aos Fóruns tomados como eventos particulares.

É digno de atenção que seja um objeto textual - a Carta - a referência permanente da "unidade de diversos" que o Fórum Social Mundial busca estabelecer. A Carta de Princípios consolida-se ao longo do tempo como o símbolo máximo da pretendida coerência interna do Fórum e de sua permanência temporal, bandeira à qual se atribui precedência sobre quaisquer conflitos e sobre a mobilização intermitente dos fóruns-eventos. De fato, a palavra escrita - publicada na Internet ou em papel, como material oficial, artigos de opinião e/ou artigos acadêmicos, informes em pequenas publicações de organizações envolvidas - ocupa espaço fundamental na constituição e definição do Fórum Social Mundial. Segundo Peter Waterman, o Fórum tem algo de um "santuário da palavra escrita e falada", não apenas pelo papel fundamental que a produção e circulação de textos desempenham para manter o processo vivo fora da ocorrência dos grandes encontros, mas também porque os acontecimentos mais valorizados nesses encontros são sempre alguns minutos de um orador ao microfone, diante de um público que pode variar de cinco a cinco mil pessoas, em painéis ou conferências eventualmente transcritas e postas em circulação sob forma textual (Waterman, 2009).

A palavra é a forma privilegiada também na seção "Memória do FSM" do site oficial. Aí mais uma vez é a palavra escrita que ganha protagonismo. Essa memória parece quase inteiramente feita de transcrições de discursos proferidos durante os eventos, boletins informativos enviados aos participantes durante sua preparação e, principalmente, de análises e balanços: textos descritivos, programáticos e críticos, produzidos por autores intelectual e politicamente mobilizados por diferentes experiências de participação no Fórum Social Mundial. Michael Albert escreve, em seu balanço do FSM de 2002: "Foi exaustivo, sem fronteiras, sem pontos finais". Possivelmente em resposta à mesma sensação, compartilhada por muitos participantes ${ }^{12}$, o que está em jogo nesse corpo de textos analíticos é introduzir pontuação, ênfases e cadência na polifonia aberta e exaustiva dos grandes eventos. Os textos interpretam fatos e discursos, associam ideias, constroem perspectivas de análise, julgam, classificam, nomeiam impasses.

\footnotetext{
${ }^{12}$ No ano seguinte, na apresentação de sua coletânea de artigos e entrevistas, Isabel Loureiro, Maria Elisa Cevasco e José Corrêa Leite expressam a sensação comum: “Acabado o Fórum Social Mundial de 2002 em Porto Alegre, os organizadores deste livro, certamente refletindo um sentimento comum a muitos, tiveram que enfrentar sua incapacidade de fazer um balanço coerente da experiência vivida naqueles cinco dias. Conversando com uns e outros na esperança de construir uma visão de conjunto minimamente sistematizada, encontravam como resposta dúvidas e complexidades" (Cevasco, Leite e Loureiro, 2002, p. 9).
} 
Uma imensa variedade de textos desse tipo acompanha a realização dos eventos do FSM, publicados com o intuito explícito de intervir nos amplos debates que os encontros alentam, ao mesmo tempo em que tratam de propor o Fórum como um nicho central de formação de opiniões, de propagação e síntese de argumentos. Produzir análises e fazer balanços, qualquer que seja o alcance, é parte daquilo que Boaventura de Souza Santos chamou de "movimento utópico e epistemológico" do próprio Fórum (Santos, 2005, p. 15). Tais avaliações têm por autores intelectuais conhecidos apenas no universo do FSM ou além dele, ou ainda aqueles que não aparecem em bibliografias, existindo por meio de designações coletivas ou permanecendo voluntariamente anônimos. Como militante da Marcha Mundial das Mulheres, eu mesma contribuí com essa produção textual, além de ter colaborado com a elaboração de documentos coletivos, publiquei dois textos assinados sobre o Fórum Social Mundial: um artigo para um dossiê da Revista de Estudos Feministas, e, mais tarde, o artigo "Después de Mumbai", publicado na coletânea Mumbai - Foro Social Mundial 2004, organizada pela ativista e escritora catalã Esther Vivas.

Tendo em comum o fato de terem sido concebidos por seus produtores como formas de intervenção, esses textos escritos, transmitidos e lidos em silêncio ou em voz alta, são também responsáveis por dar vida a um "processo fórum" - expressão muito comum entre organizadores e participantes, que designa tudo aquilo que o FSM se torna quando deixa de ser apenas um evento. A ideia de processo é produzida, em grande medida, graças a essa circulação de textos, e é indispensável para que o Fórum seja percebido como algo contínuo: uma unidade dinâmica, permanente e em evolução, por oposição à ideia do encontro esporádico, pontual.

É possível dizer que, do ponto de vista do engajamento dos autores e da noção processual que os orienta, escrever para o Fórum e escrever o Fórum são movimentos quase indistintos, que produzem sua existência social e cultural. As categorias pelas quais os textos de análise enunciam as experiências coletivas são inseparáveis da constituição do Fórum Social como acontecimento político e histórico. Assim, o "Fórum processo" compreende uma densa formação de enunciados, modos de narrativa e descrição, espacializações, temporalizações e segmentações políticosemânticas. Desse ponto de vista, os enunciados de análise e balanço são acontecimentos discursivos, produzindo efeitos na história que os precede e que virá depois. Como sugere Foucault, trata-se de acontecimentos ao mesmo tempo presos ao gesto transitório da escrita ou da fala e abertos à uma persistência complexa no campo da memória (Foucault, 1969, p. 41).

Tomar textos de análise e balanço como um conjunto de fontes primárias foi a forma que encontrei de transpor a sensação de opacidade e esgotamento que me provocou o interminável fluxo de discursos produzidos em torno do Fórum Social Mundial, fortemente carregados de repetições, sensação esta que esteve na raiz da minha resistência inicial a desenvolver um projeto de pesquisa 
sobre o tema. Este esforço tomou, justamente, a direção de um exercício de descrição e problematização de algumas das fórmulas mais recorrentes, lugares comuns produzidos nesse campo discursivo (magnético e minado). A partir destes documentos e discursos, mais do que construir um mapeamento de atores e instâncias institucionais do FSM - com seus mecanismos de negociação, redes de relações e conflitos internos - interessa-me observar como essas formulações, em suas recorrências, constituem uma prática ou "modo de fazer". Tomo emprestada a expressão de De Certeau, em $A$ Invenção do Cotidiano (1980), para destacar a complexidade dessa produção textual que se dá no âmbito do processo FSM: ao mesmo tempo um modo de fazer parte do Fórum e de fazê-lo existir enquanto experiência política particular. Trata-se, assim, de interpelar o dito "movimento epistemológico" do Fórum Social Mundial desde o ponto de vista das práticas que o constituem, a começar pelas práticas discursivas: as formas contidas nos textos escritos sobre o Fórum que fazem parte do que ele é, assim como o olhar de um colecionador faz parte das peças que compõem a sua coleção.

Entre os artigos reunidos em publicações a que tive acesso, e levando em conta sua ampla variedade de tons e temáticas, é raríssimo encontrar análises que soem distanciadas de seu objeto ou que não sejam tocadas, ainda que sutilmente, por alguma urgência militante. Por exemplo, em 2005, a Ephemera, revista independente sobre "teoria em política e organização" apoiada pela escola de Administração e Negócios da Universidade de Londres, dedica um número aos Fóruns Sociais. No editorial, os organizadores, Böhm, Sullivan e Reyes, chegam a descrever o engajamento dos textos que apresentam ao público como inseparáveis da própria natureza de seu objeto político: “uma vez que a política desse movimento objetiva a transformação da vida enquanto tal, as contribuições[...] não são meras representações: ao contrário, são intervenções ontológicas em um projeto político da transformação radical do ser" (Böhn; Sullivan; Reyes, 2005, p. 99). Vemos como o texto define o FSM como uma "referência magnética para a cultura política crítica" da década passada, algo da natureza do "fato social total", que se constituiu como uma rede de relações e ideias, mas também, é importante acrescentar, uma constelação de dimensão prática, feita de modos de dizer e maneiras de fazer $^{13}$.

Os textos cuja análise é o ponto de partida desta tese foram produzidos em nome de organizações e representantes integrantes do Conselho, envolvidos diretamente nas tarefas organizativas e processos decisórios do FSM: colaboradores permanentes ou eventuais do Comitê Organizador e comissões do Conselho Internacional, alguns deles ligados a coletivos,

\footnotetext{
${ }^{13}$ Como propõe Michel De Certeau, discursos e práticas, nesse caso, não apenas são inseparáveis, mas podem ser analisados de uma perspectiva semelhante: "Como na literatura diferenciamos 'estilos' ou maneiras de escrever, podemos distinguir 'maneiras de fazer' - de andar, de ler, de produzir, de falar, etc" (1980, p. 51).
} 
representantes de movimentos e organizações, e outras pessoas mobilizadas em função de um envolvimento político mais personalizado. Entre os autores, há também os militantes e intelectuais não envolvidos nas tarefas organizativas do "processo-fórum", muitas vezes participantes e organizadores de iniciativas inscritas nos eventos, interessados nas temáticas de debate internas ao Conselho, entendidas como parte de uma reflexão mais ampla sobre questões políticas de grande alcance $^{14}$.

Tal produção textual percorre um leque de questões que está então na ordem do dia: os impasses contemporâneos da democracia, a crise e a possível recomposição das formas de organização política, os novos desafios do internacionalismo de esquerda, o embate ainda pendente pelo reconhecimento de subjetividades políticas marcadas pela diferença - mulheres, negros, indígenas, jovens, homossexuais e transgêneros. Debates particularmente animados são travados em torno do potencial criativo e conflitivo de uma geração política dita "nova", que dá corpo aos protestos anti-globalização, pronta a recolocar em questão os discursos, modos de ação e organização consolidados pelas gerações anteriores (Di Giovanni, 2003). Evidentemente, os textos produzidos em torno do Fórum Social Mundial em seus primeiros anos de existência também integram um debate sobre as respostas e estratégias necessárias para romper a hegemonia política e ideológica do neoliberalismo. Trata-se, ao mesmo tempo, de um momento de ampliação e transformação do espaço de combate ao mito do fim da história. A mobilização dos recentes exemplos de organização e ação torna-se indispensável aos intelectuais que buscam apoiar experiências sociais alternativas ao modelo de acumulação capitalista organizado em escala global, consolidado nos anos 90, com protagonismo das corporações internacionais e grande grupos investidores (Seoane e Taddei, 2000; Aguiton, 2002; Bensaid, 2003; Leite, 2003)

Para explorar esse universo textual que cerca os anos de criação e constituição do Fórum Social Mundial, heterogêneo nos formatos, temas e estilos, procurei inicialmente destacar termos recorrentes e entender como alguns deles são usados pelos autores. Tal procedimento torna bastante evidente que, em se tratando da vida política brasileira e latino-americana, estamos ainda em cheio no campo daquilo que Evelina Dagnino (2004) chama de "deslizamentos semânticos" que marcam a criação e ampliação de espaços públicos de embate político nos anos 80: um intenso trânsito de significados que atravessa as noções de democracia, participação e sociedade civil. Empregados à exaustão naquele período, esses e outros termos são incorporados ao vocabulário do Fórum Social Mundial, trazendo consigo uma densa carga de contradições.

\footnotetext{
${ }^{14}$ É necessário esclarecer que tratei apenas de textos de acesso público, cuja produção e circulação se misturam com as discussões estabelecidas na preparação dos Fóruns e com sua repercussão. O leitor não encontrará aqui referências a nenhum documento "secreto".
} 
Nosso foco aqui recai sobre zonas de tensão semelhantes àquelas descritas por Dagnino no contexto da disputa político-semântica envolvida na construção de formas de participação da dita sociedade civil, ao redor das ideias de expansão da cidadania e do aprofundamento da democracia. Neste processo, segundo a autora, as organizações, movimentos sociais e militantes, apostando no potencial democratizante de sua participação nas instâncias decisórias e no surgimento de formas novas de relação com o Estado, viram-se enredados no emaranhado jargão que haviam ajudado a constituir. Uma trama perversa, dirá Dagnino, porque a mesma fluidez de significados que permite estabelecer um vocabulário "comum" entre campos antes separados e interesses distintos, termina por tornar opaca a dimensão da ação, tornando menos visíveis projetos e intenções políticas e obscurecendo divergências.

\section{Estratégia: categoria "nativa"}

As primeiras leituras e contatos retomados com antigos participantes e organizadores foram marcados pela recorrência com que a noção de estratégia era empregada, mobilizada particularmente quando se queria atribuir ao FSM o caráter de um processo, um sentido de continuidade e permanência. Entre os modos de dizer e fazer que participam do Fórum, os discursos da estratégia, não necessariamente coerentes entre si, são inseparáveis da constituição do FSM como uma totalidade - processual, espacial ou temporal.

Estamos diante de um conceito complexo, quase nunca problematizado pelas análises a respeito do Fórum e empregado em contextos distintos com sentidos diversos, servindo para amarrar séries de questões, validando ou condenando procedimentos, fundando desavenças ou alianças. Evidentemente não estamos falando de um conceito nascido ontem, nem no interior do Fórum Social Mundial: ele possui uma longa história, povoado de significados sempre mutáveis.

Tão difundida quanto difícil de definir, a noção de estratégia acabou por se tornar o primeiro fio condutor do percurso desta tese em função de sua relação com uma série de problemas centrais para o desenvolvimento da pesquisa. Antes de mais nada, a mobilidade de significados que ela abarca permite manter em foco uma tensão metodológica de fundo: minha posição como pesquisadora é inseparável de relações políticas e afetivas resultantes de uma atuação como ativista ao longo dos primeiros cinco anos do Fórum Social Mundial que tanto os companheiros de militância quanto os colegas pesquisadores sabem ser também “estratégicas". A noção de estratégia coloca em movimento ambos os lados dessa relação: não é apenas uma figura comum do discurso militante, mas também uma categoria fundamental das teorias da política que informam as referências acadêmicas da pesquisa, é um conceito que nunca deixa de oscilar entre categoria nativa e operador teórico. Um olhar atento a essa oscilação revela como definições políticas no campo do 
FSM têm sido construídas igualmente por acadêmicos e militantes, cujas formulações se contaminam mutuamente, todo o tempo.

Esta contaminação é, ao mesmo tempo, uma característica do objeto de investigação e uma perspectiva de análise: a escolha dos materiais faz colidir o gesto analítico próprio do pesquisador com outros enunciados analíticos, sejam eles teóricos ou militantes. Se proponho uma reflexão sobre a estratégia como "categoria nativa", uso as aspas apenas para indicar que, neste caso, o caráter "nativo" é irremediavelmente um lugar a ser ocupado ora por ativistas imersos na experiência política, ora por analistas supostamente distanciados dela. As categorias da observação encontram-se postas em campo, sujeitas aos mesmos usos políticos, estéticos e afetivos que articulam as formas observadas: convidam, em ambos sentidos, a um exercício de estranhamento.

Longe de pretender uma defesa formal da observação participante, a opção de partir de uma categoria de mão-dupla serve aqui para mostrar um aspecto fundamental dos tais modos de fazer no Fórum Social Mundial. Nesse sentido, Jeffrey Juris (2007), ativista e pesquisador dos movimentos antiglobalização, sustenta que a produção e circulação de análises entre estes militantes não apenas é intensa desde a metade da década de noventa, como constitui em si uma forma importante de seu ativismo e organização. Por um ângulo diferente, este aspecto de circulação multidirecional de análises é destacado por Boaventura de Souza Santos, já no contexto específico do FSM. O autor atribui caráter de inovação epistemológica às práticas políticas que o Fórum supostamente inaugura, que teriam sido criadas em um "diálogo crítico com o modo tipicamente vertical da produção de conhecimentos" associado à "face colonial da modernidade" (Santos, 2005). Como reitera Janet Conway (2008), esta leitura leva a uma caracterização do FSM como práxis baseada na busca de uma epistemologia - um modo de conhecer e analisar o mundo - autônomo em relação ao pensamento eurocêntrico em que estariam fundadas as formas "neoliberais" de pensamento e ordenamento político-econômico.

Embora provenientes de caminhos analíticos muito diferentes, as formulações destes autores reforçam a percepção de que a produção de enunciados ostensivamente reflexivos a respeito das formas de fazer política, é a prática mais amplamente reconhecida como característica do FSM, e um dos modos mais visíveis pelos quais uma pessoa ou coletivo pode fazer parte dele.

A noção de estratégia é então fundamental para observarmos o Fórum da perspectiva dessa produção contínua e muito prolífica de discursos reflexivos, de onde retiramos os materiais desta análise. Como já sugerimos, trata-se de uma categoria abertamente vinculada ao universo discursivo e performático das análises e balanços. Está ligada, nessa medida, aos modos de fazer próprios das elaborações generalizantes e teorizantes; às falas de autoridade que tomam a forma de conferências, entrevistas à imprensa e intervenções de especialistas em seminários; à escrita e à palavra dos 
intérpretes do FSM, lideranças, intelectuais e acadêmicos. Ela também aparece com esse mesmo tom generalizante nos textos reconhecidos como "oficiais" do Fórum, tais como a Carta de Princípios (Fórum Social Mundial, 2001), informes e outros documentos internos.

Ainda que se possa afirmar, como espero demonstrar no Capítulo II, que o uso da noção de estratégia tenha perdido terreno diante da proliferação de outros termos, hoje mais facilmente reconhecidos como próprios ao jargão do Fórum Social Mundial, não há razões para acreditar que ela não esteja mais lá. Gustave Massiah (2011), um dos porta-vozes da ATTAC francesa e membro do Conselho Internacional, retoma recentemente o assunto, buscando descrever o "movimento altermundialista" como um processo de natureza fundamentalmente estratégica, de que o FSM seria um produto, uma expressão avançada e uma forma prática definitiva. Segundo ele, a definição deste movimento não se refere a um bloco ideológico homogêneo, mas a uma "posição no debate estratégico que abrange posicionamentos e avaliações diferentes sobre as oportunidades e as alianças" (Massiah, 2011, p. 94).

Também na definição de Massiah, a estratégia refere-se fundamentalmente a uma relação entre o conhecimento do mundo - dos "elementos de contexto" ou dos acontecimentos que constituem o "agora" - e a ação política compreendida como algo contínuo, que se projeta no futuro. Essa relação se traduz, segundo o autor, na constituição de questões e temas de debate, na multiplicidade de propostas e projetos apresentados durante os encontros e também, é importante destacar, nas expectativas dos "altermundialistas" com relação ao próprio Fórum Social Mundial e seu papel em um processo linear de transformações históricas (Massiah, 2011, p. 95).

$\mathrm{Na}$ base de grande parte das análises produzidas sobre o FSM, o sentido da estratégia está ainda ligado a um esforço de leitura histórica, de interpretação deste a partir de suas relações com o passado e com o futuro. Nesse sentido, são também cronosofias, elaborações de um conhecimento temporal, no sentido descrito por François Hartog: "misto de profecia e periodização", que buscam apreender as relações entre passado e futuro, dominá-las, compreendê-las e fazer previsões (2008, p.22). Muitas destas análises descrevem a origem do Fórum Social Mundial partindo de uma reconstrução cronológica dos movimentos de protesto que remonta ao início da década de noventa ou mesmo às primeiras décadas o século XX, em uma sequência genealógica de fatos manifestações, levantes, greves, marcos de crises políticas e econômicas (Aguiton, 2002; Leite, 2003; Seoane e Taddei, 2001; Bensaid, 2003; Wallerstein, 2004; Nunes, 2005). Não faltam na história imagens de um desenvolvimento progressivo e linear, como a que encontramos no relato de Diego Azzi sobre um exercício realizado durante o FSM 2007, em Nairobi, Kênia: 
realizou-se uma oficina na qual era pedido a cada um dos participantes de diversos países que desenhassem um gráfico da evolução das lutas globais e nacionais, de 1994 a 2007. Ao se compartilhar os resultados, observou-se uma impressionante recorrência de curvas das lutas globais, sendo bastante ascendentes de 1994 a 2001, estáveis de 2002 a 2003 e fortemente declinantes de 2004 a 2007 (Azzi, 2007, p. 163).

Uma curva imaginada atinge seu ápice em 2001, uma espécie de clímax de vitalidade dos protestos antiglobalização das instituições multilaterais e corporações internacionais (Di Giovanni, 2012). Neste momento, percebido como auge da ascensão de um novo movimento internacional, fruto da interação sem precedentes entre movimentos de natureza e origem geográfica muito diversa, é que diferentes autores localizam a origem do Fórum Social Mundial. A descrição deste tipo de sequência temporal costuma aparecer como preâmbulo nas análises e balanços: as cronologias, situando o FSM em uma relação entre passado e futuro, entre o espaço das experiências e o horizonte das expectativas (Koselleck, 1979), parecem inseparáveis daquilo que reconhecemos como reflexão estratégica.

Também no registro das elaborações de caráter temporal, que deixam ver o empenho de participantes e organizadores em escrever uma história de acontecimentos e ideias, a estratégia é uma categoria que atravessa os anos em que o Fórum forma-se como unidade processual e institucional. Sob a rubrica da reflexão estratégica encontramos conexões entre a consolidação de certas práticas - formas de organização de encontros e de debates, circulação de propostas, expressão de acordos e divergências - e a construção das chaves explicativas e reflexivas que estruturam um universo discursivo. Ainda que em muitos documentos o termo estratégia esteja ausente, em particular nos documentos de preparação e informes, essas conexões de caráter estratégico aparecem no uso de outras palavras, na constituição de um vocabulário e de uma voz própria do FSM.

\section{Práticas e lugares de poder}

É corrente encontrar a palavra estratégia como categoria fundamental da análise política. Ao lado da noção de tática, seus usos remontam à história das revoluções burguesas, e proliferam quanto mais as formas da guerra tornam-se objeto de estudo, definindo um paradigma de compreensão das relações políticas ou econômicas. O conceito teria sido difundido entre militares pela obra de Karl von Clausewitz (1780-1831), autor que, segundo Che Guevara, Lenin gostava de citar pela clareza de suas ideias, ainda que se tratasse da "análise de um burguês" (Guevara, 1962). De fato, é no período posterior à Revolução Russa que o conceito militar de estratégia passa a figurar em manuais e programas políticos como categoria específica, relativa à luta revolucionária 
pela tomada do poder (Harnecker, 2005). Na segunda metade do século XX, o tom insurgente da estratégia, embora reforçado nos contextos de luta armada na América Latina, parece ter se diluído na medida em que usos particulares do termo proliferam pelos mais diferentes campos da organização social e da ação coletiva. Dos sindicatos às ONGs, passando por sua apropriação concomitante pelo mundo empresarial e pelo marketing publicitário, a noção de estratégia permanece associada às funções de eficácia e acúmulo, preservando, em sua dispersão semântica, o antigo nexo bélico da conquista de objetivos.

Embora muito empregada pelos participantes, organizadores e palestrantes para descrever e justificar o encontro de Porto Alegre, a estratégia não é incluída no texto da Carta de Princípios elaborada após o primeiro evento do Fórum Social Mundial em 2001. Apenas anos mais tarde, criase uma Comissão de Estratégia(s) do Conselho Internacional do FSM que, passando por várias transformações em sua composição e propósitos, segue em operação até os dias de hoje. O documento "Regras de Funcionamento do Conselho Internacional do FSM", aprovado na reunião do Conselho Internacional de junho de 2003, em Miami, formaliza o funcionamento dessa e de outras comissões ${ }^{15}$. Na descrição do trabalho da comissão, o termo aparece no plural: trata-se agora de uma "Comissão de estratégias" cuja tarefa é:

aprofundar as análises das estratégias, das iniciativas e ações dos agentes do neoliberalismo, bem como das iniciativas dos que se contrapõem à dominação neoliberal (movimento mundial anti ou alter mundialista), visando a facilitar o debate de estratégias de resistência e construção de um outro mundo possível (Regras de Funcionamento do Conselho Internacional do FSM, 2003).

A "construção de um outro mundo possível", formulação que aspira à unanimidade ao incorporar os termos do exitoso lema do Fórum, ocupa o lugar do objetivo a ser conquistado. Ao mesmo tempo, essa é a única passagem neste documento a apontar um "lado de fora" do próprio processo Fórum e a indicar uma luta a ser travada entre o "conjunto de iniciativas dos que se contrapõem à dominação neoliberal" e os "agentes do neoliberalismo"- além daquela que descreve as tarefas de comunicação como "construção de sistemas de informação do processo FSM para além de sua esfera" - a apontar um "lado de fora" do próprio processo Fórum e a indicar uma luta a ser travada entre o "conjunto de iniciativas dos que se contrapõem à dominação neoliberal" e os "agentes do neoliberalismo". A referência às "correlações de força" ou à "tomada do poder", no entanto, parece ter sido evitada. O movimento circular da construção é notável: a tarefa é

\footnotetext{
${ }^{15}$ As comissões mencionadas pelo documento são: Estratégias, Conteúdos, Metodologia, Expansão, Comunicação e Finanças.
} 
aprofundar uma análise das estratégias para facilitar o debate sobre estratégias. Examinada segundo o sentido que lhe atribuíram Clausewitz ou Lenin, a sutileza da definição parece beirar o absurdo.

Se a noção de estratégia é tão sutil nesses documentos, por que identificá-la como um termo chave na concepção do Fórum? Certamente a importância da noção não é dada por sua coerência conceitual nem sua genealogia nos leva a algum tipo de essência estável original ${ }^{16}$. Ela nos interessa porque, sujeita a diferentes usos, costuma aparecer e desaparecer sempre em função da ideia de que o FSM constitui uma totalidade. Cada uso diferente da noção, e mesmo seu desaparecimento, tem a ver com modos distintos pelos quais se entende e experimenta esse sentido de unidade política. Por exemplo, a nomeação de uma Comissão de Estratégias pode ser entendida, antes de mais nada, como um gesto de afirmação da unidade: afirma-se que o FSM deve ser dotado de um sentido estratégico, deve ter uma "visão do todo" (Escobar, 2009, p. 398). Ainda que um objetivo comum não se apresente como um dado ou condição para a realização dos encontros, a criação da comissão após a realização dos dois primeiros Fóruns em Porto Alegre parece validar a busca de um sentido comum como tarefa coletiva.

A palavra estratégia pode também ser evitada, para permitir uma enunciação diferente da unidade do Fórum como processo. Ainda que a tarefa de construir um sentido comum esteja posta na mesa, a definição de uma estratégia ou "visão do todo" no singular não é considerada uma condição do espaço comum. A estratégia concebida como uma perspectiva única, que ordena entendimentos e ações, pode até ser considerada uma ameaça: “Aqui, noções de lutas prioritárias e secundárias, alimentadas por entendimentos monolíticos da globalização neoliberal, não ajudam”, afirma Gina Vargas, "Neste espaço não há lutas ou identidades homogêneas a ser 'representadas"” [...] “mas múltiplas visões, experiências e estratégias”(2009, p. 188). Apesar das ressalvas, é importante notar que esse discurso pluralista sobre o Fórum é também um modo de produzir um "aqui”, recortando-o contra o fundo das experiências políticas ditas anteriores. Independente da adoção de um "ponto de vista único", da designação de uma demanda comum ou um objetivo a ser conquistado, vemos delinear-se uma estratégia em sentido semelhante ao que descreve Michel de Certeau:

Chamo de estratégia o cálculo ou a manipulação das relações de força que se torna possível a partir do momento em que um sujeito de querer e de poder (uma empresa, um exército, uma cidade, uma instituição científica) é isolado. Ela postula um lugar suscetível a ser circunscrito com próprio (...). (1980, p. 59).

\footnotetext{
${ }^{16}$ Como explica Foucault: "por trás das coisas há 'qualquer outra coisa': de forma alguma seu segredo essencial e sem data, mas o segredo de que elas são sem essência, ou que sua essência foi construída peça por peça a partir de figuras estrangeiras a ela" (Foucault, 1971, p. 148).
} 
Antes de estar referida a algum objetivo, segundo o autor, a estratégia é o gesto que postula um lugar "próprio", esse "aqui" separado do resto do mundo, a partir do qual é possível gerir e manipular relações com alvos e ameaças "externos": inimigos, concorrentes e colaboradores ocasionais, públicos, objetos e objetivos. A estratégia nesse sentido está também presente na elaboração de "lugares teóricos": de sistemas e discursos totalizantes, como no gesto característico da modernidade científica, política ou militar (De Certeau, 1980, p. 59).

Assim, é possível pensar a noção de estratégia não exclusivamente como relação entre a ação e um objetivo a ser conquistado, mas, fundamentalmente, como fórmula pela qual efeitos de totalização são produzidos na experiência individual e coletiva. A possibilidade de que um conjunto de eventos ou mesmo um processo colaborativo entre diferentes sujeitos possa ganhar um nome próprio - Fórum Social Mundial - é impensável sem o mesmo gesto que circunscreve um espaço político. Neste sentido, mesmo riscada do dicionário, a estratégia segue operando em um Fórum que está a constituir-se como um sujeito com espaço "próprio" de onde projetar visões, mensagens, análises, imagens, propostas, campanhas, acusações e conspirações. Ainda que definido como forma "diferente de todos os modelos da organização política moderna" (Santos, 2009, p. 192), o Fórum é enunciado como um lugar de saber, querer e poder, onde se espera manipular relações de força, assim como "as estratégias militares ou científicas sempre foram inauguradas graças à constituição de campos 'próprios' (cidades autônomas, instituições 'neutras' ou 'independentes', laboratórios de pesquisa 'desinteressados', etc.)" (De Certeau,1980, p. 60).

Curiosamente, como já mencionamos, a Carta de Princípios - difícil imaginar um objeto mais explicitamente instituinte de um querer e poder próprios do que uma Carta de Princípios indica que o FSM "não se constitui em instância de poder, a ser disputado pelos participantes de seus encontros" (2001). Como mencionei anteriormente, o FSM, desde seu início, evita publicar declarações ou assumir decisões. Essa interdição é parte do pacto de sua fundação e um elemento considerado central da Carta de Princípios, percebida como a própria alma do Fórum. Isso serviria para garantir que "os participantes encontrem uns aos outros, em vez de competirem por hegemonia sobre o fórum" (Conway, 2008, p. 1).

Como na imensa maioria das definições oferecidas nos documentos oficiais, na primeira linha do texto da Carta, encontramos uma outra qualificação: "o Fórum Social Mundial é um espaço aberto" (Carta de Princípios, 2001). Como ressalta Janet Conway (2008), a ideia de "espaço" remete diretamente a esse caráter não deliberativo, desprovido das habituais demarcações de lugares de poder. Segundo a análise de Gina Vargas, o FSM “não chega a conclusões ou produz declarações públicas, porque isso comprometeria a variedade de diferentes redes, organizações e movimentos que participam, e que se sentiriam obrigados, de alguma maneira a aceitar uma posição única”. Não 
havendo um querer único a ser definido, o Fórum estaria livre de se tornar um campo de poderes em que o estabelecimento de declarações e propostas "necessariamente monolíticas" significaria a dominação de um grupo sobre os demais (Vargas, 2009). Se a forma evasiva da definição das tarefas da Comissão de Estratégias parece querer escapar da definição de um objetivo, o gesto estratégico da Carta de Princípios trata de desfazer o lugar de poder que, segundo a definição de De Certeau, deveria constituir.

Segundo vários analistas e comentadores, essa evitação de um discurso direto que possa pretender direcionar a ação de seus participantes e explicitar fronteiras internas ou externas é a própria marca do Fórum Social Mundial. Por exemplo, Antonio Negri e Michael Hardt que, em prefácio ao trabalho de compilação dos documentos e debates do FSM 2002 realizado por Thomas Ponniah e William Fisher, explicam:

não é questão de definir um ponto de unidade ou, pior ainda, de identidade, mas simplesmente encontrar o que há de comum em nossas diferenças e expandir o que é comum enquanto nossas diferenças proliferam [...]Cada diferença é um projeto organizacional, (Hardt e Negri, 2003, p. xviii).

Os termos empregados deixam claro: o que se propõe não é uma estratégia como gesto de unificação e circunscrição, mas, ao contrário, como marca de um projeto de proliferação da (e pela) diferença.

Boaventura de Souza Santos, na passagem sobre "Estratégia e ação política" de seu Manual de Uso do FSM, por sua vez, atribui a novidade do Fórum ao mesmo "minimalismo" da Carta de Princípios:

acesso quase incondicional (só estão excluídos os movimentos ou grupos que advogam a violência); ausência de votações ou deliberações no Fórum enquanto tal; ausência de uma entidade representativa [...]. É quase semelhante a uma tábula rasa onde têm lugar todas as formas de luta contra o neoliberalismo [...] aqueles que optam pela auto-exclusão sentem dificuldade em definir com rigor aquilo que os está a excluir (SANTOS, 2005, p. 89-90).

Trata-se de um gesto de unificação pelo avesso, espécie de discurso negativo da estratégia em que os objetivos são evitados e o lugar de poder comum é submetido a uma força permanente de dispersão. Na lógica do espaço aberto, as exclusões, quando acontecem, segundo Santos, são "autoexclusões", resultado da falta de adesão de parte de sujeitos autônomos e não de efeitos de um poder próprio ao FSM. Essa seria então a inovação política e epistemológica do processo Fórum: uma inversão de sinais que pretende prevenir que esse processo seja definido por quaisquer categorias ou objetivos demasiado claras. A forma de um "espaço aberto" pode assim reger-se 
inteiramente pelos critérios de sua própria reprodução como forma ou como método. O papel das instâncias organizativas também é descrito por Francisco Whitaker como alheio a relações de poder: "na opção pelo Fórum-como-espaço, esse tipo de organização não deve dirigir aqueles movimentos e organizações [participantes], mas apenas endossar e apoiar a criação de mais espaços Fórum" (2009, p. 93).

A inovação do espaço aberto consiste em manter o "lugar de poder" continuamente esvaziado e o lugar de querer permanentemente aberto a uma pluralidade ilimitada de desejos. A essa tarefa política proposta como não estratégica, "de baixa intensidade" e supostamente livre da tradicional epistemologia linear de esquerda, Boaventura de Souza Santos dá o nome de tradução: a produção de inteligibilidade entre experiências presentes e futuras, de todas as partes do mundo, que não deve jamais destruir a identidade daquilo que é traduzido (Santos 2009, p. 384-386). Nessa Babel alternativa, em vez de serem punidos, pela audácia de seu projeto comum, a nunca mais serem capazes falar a mesma língua, os homens podem se entregar ao eterno exercício de linguagens comuns cada vez mais complexas, já que não há nenhum edifício a projetar e a construir. Cabe observar que o segundo slogan do FSM, "contra o pensamento único", - empregado para atacar a forma impositiva do chamado pensamento neoliberal, cuja fórmula, atribuída a Margaret Tatcher, é "Não há alternativa" - parece, desde a instituição da Carta de Princípios, estar voltado para o interior do Fórum. O slogan funciona para prevenir a emergência de qualquer "receita ou um agente específico" e para garantir a proliferação de "múltiplos atores sociais contribuindo com suas formas de resistência e construindo a democracia com justiça social e equidade" (Vargas, 2009).

Chega a parecer contraditório ser o Fórum Social Mundial convocado com base naquilo que, apelando a uma terminologia não tão inovadora, chamaríamos de "tomada de posição". Afinal, ele é concebido com seu título como um evento simultâneo e antagônico à realização anual do Fórum Econômico Mundial em Davos, Suíça, como uma espécie de contra-evento, como os protestos de Seattle, Praga ou Gênova, realizados em oposição às reuniões oficiais da Organização Mundial do Comércio, do Fundo Monetário Internacional e do G8 (Di Giovanni, 2012). É no calor dessas manifestações "antiglobalização" que se dá o primeiro Fórum Social Mundial, entre 25 e 30 de janeiro de 2001, na cidade de Porto Alegre, como um primeiro encontro anti-neoliberal mundial. Um ritual, que depois torna-se periódico de integração, fortalecimento e renovação de correntes políticas, mas também um ritual pelo qual é marcado o posicionamento contrário às elites transnacionais hegemônicas.

"Pobre parece toda palavra para dar conta dessa fabulosa Babel onde, contrariando a parábola bíblica, a tumultuosa diversidade de movimentos, sensibilidades e idiomas compartilhou 
ideais e ações", diriam José Seoane e Emilio Taddei ${ }^{17}$, em texto publicado no mesmo ano de 2001, onde descrevem e comentam os debates, de cunho diagnóstico e programático, transcorridos no encontro, tendo como ponto de partida a denúncia da financeirização, da mercantilização, da desregulação e da concentração de poder e riqueza percebidos como estruturantes da globalização capitalista. Os organismos internacionais, frente aos quais se davam ainda manifestações massivas de "um movimento global de movimentos", são identificados, também no contexto do Fórum, como mecanismos chave de uma estrutura política mundial regida pelos interesses de grandes grupos financeiros e pelas corporações transnacionais (Seoane e Taddei, 2001, p. 122).

Durante os "intensos, exaustivos e vibrantes" dias do Fórum Social Mundial, nos termos dos mesmos autores, altas temperaturas, espaços apinhados e ruidosos, e grandes doses de euforia coletiva inspiram profusa adjetivação, conferindo formas tangíveis às oposições políticas abstratas e produzindo oposições sensíveis entre "A primavera social de Porto Alegre" e o "seleto e mediatizado" parlamento dos capitalistas, funcionários e "gurus globalizadores", que se reúnem simultaneamente no inverno de Davos, amparados por um monumental esquema de repressão às manifestações contrárias. O sentido "anti Davos" chega a ser posto em cena em 2001, através de um dramático confronto via satélite, acompanhado pela torcida local através de telões, que opôs por duas horas uma delegação calculadamente heterogênea de onze representantes do povo reunido na capital gaúcha a quatro senhores brancos de meia idade vestidos em impecáveis ternos de tons sóbrios, alinhados em nome do Fórum de Davos (Seoane e Taddei, 2001, p.106). No entanto, não poderia este episódio ser considerado contrário à Carta de Princípios (adotada meses mais tarde), por conferir a algumas figuras a posição interdita de "falar em nome do Fórum"? É como se diante da nova forma de fazer política que o FSM traz consigo, em sua defesa das diferenças, tomar posição seja pouco (ou seja muito).

As exuberantes poéticas da oposição a Davos são compensadas, nas análises e balanços do Fórum daquele ano, pela defesa enfática de que, apesar do farto jogo de oposições, trata-se definitivamente de mais do que uma mera imagem especular do Fórum Econômico. Nas vozes dos analistas, o Fórum de Porto Alegre é celebrado principalmente como um avanço com relação às grandes manifestações de rua que marcaram o momento político do final da década de 1990 e os primeiros anos do século XXI, quando parecia bastar um uníssono "sou contra!". Ignácio Ramonet, diretor do Le Monde Diplomatique - veículo importante de difusão de balanços e análises do e sobre , FSM - afirma que se trata de um encontro

\footnotetext{
${ }^{17}$ Cientistas sociais argentinos, envolvidos no FSM, durante os anos de sua realização em Porto Alegre, como representantes do Conselho Latino Americano de Ciências Sociais (CLACSO) .
} 
não para protestar, como em Seattle, Washington, Praga e outros lugares, contra as injustiças, as desigualdades e os desastres que os excessos do neoliberalismo provocam pelo mundo, um pouco em toda parte. Mas sim para tentar, em uma espírito positivo e construtivo dessa vez, propor um quadro teórico e prático que permita conceber uma mundialização de novo tipo e afirmar que um outro mundo menos desumano e mais solidário é possível (RAMONET, 2001).

Na visão de Taddei e Seoane, já mencionados:

Essas propostas que ganharam visibilidade no Fórum não falam apenas da consolidação e legitimidade do movimento anti-globalização neoliberal como uma caixa de ressonância do protesto, mas também como uma experiência de fixar novos horizontes e um programa concreto e realista de transformações econômicas e sociais (Seoane e Taddei, 2001, p. 122).

No mesmo sentido, o documento Histórico do Processo FSM, datado de 2 de outubro de 2007, não assinado e disponível no site oficial do escritório/secretaria do Fórum Social Mundial, descreve-o como um espaço internacional para a reflexão e organização "de todos os que se contrapõem à globalização neoliberal e estão construindo alternativas para favorecer o desenvolvimento humano e buscar a superação da dominação dos mercados em cada país e nas relações internacionais" (Fórum Social Mundial, 2007, grifo meu).

Se, entre 1999 e 2001, as manifestações às portas das reuniões das instituições internacionais davam a cara dos dissensos políticos "antiglobalização", o Fórum Social Mundial, dali em diante, torna-se o grande palco, não apenas dos que estavam contra, mas também e fundamentalmente dos que estão trabalhando na formulação de alternativas à dita hegemonia neoliberal. Sob o lema "Um outro mundo é possível", define-se uma forma distinta de visibilidade política. Se o termo "antiglobalização" associou-se à imagem dos protestos de rua marcados pelos confrontos entre polícia e manifestantes, ao Fórum Social Mundial adere mais facilmente o rótulo, de origem francófona, "altermundialista"18. A diferença é importante, embora Teivo Teivanen (2005), cientista político finlandês e um dos membro fundadores do Conselho Internacional, tenha razão em advertir que de "anti” a "alter" não está necessariamente implicada uma escala fixa de radicalidades ou esquerdismos.

\footnotetext{
${ }^{18}$ L. Coradini argumenta a inadequação da expressão "altermundialista". Segundo o autor, a aplicabilidade da noção no contexto de um evento realizado no Brasil é limitada pelo dado contundente de que, entre os participantes do FSM 2005, apenas lideranças cuja atividade se dá em nível prioritariamente internacional estariam familiarizadas com essa noção ou identificadas a ela. Emprego o "altermundialismo" aqui, no entanto, evocando a desconfortável oposição entre esta noção e a de "movimento anti-globalização", muito sensível nas duas primeiras edições do FSM e também expressa como distinção entre o "povo de Seattle" e o "povo de porto alegre".
} 
Embora práticas de protesto façam parte dos encontros da esquerda global em Porto Alegre desde suas primeiras edições ${ }^{19}$, a convocatória para o Fórum centrada em expectativas (e pretensões) de amadurecimento intelectual, formulação de críticas e propostas, cujas formas eram debates, reuniões, "oficinas" ${ }^{20}$ ou seminários, e não práticas da ação de rua associadas a atitudes de negação e de denúncia. O "espírito" de Seattle tinha a marca inquietante da rebeldia e da ação direta, mas o espírito de Porto Alegre, nas palavras de Ramonet, surge como algo mais "construtivo". Taddei e Seoane o descrevem como um ponto "de chegada e de partida", na passagem de um movimento de resistência a um novo estágio afirmativo (2001, p. 123).

A narrativa evolutiva da passagem dos protestos ao espaço de debates sobre alternativas que o Fórum deve representar contribui para reforçar as definições do documento de fundação e tem consequências para as formas de participação. Nas jornadas de protesto, um conjunto expressivo era composto pelos conteúdos das diversas táticas de ação: danças, palavras de ordem, discursos moderados e coquetéis molotov eram inevitavelmente somados, contaminando todo resultado ou mensagem final. Isso parecia aceitável, ainda que com algumas ressalvas, quando se tratava de um de fazer denúncias e expressar inconformidades (Di Giovanni, 2012). No FSM, espera-se que o conjunto e suas partes não se confundam. Janet Conway afirma essa separação como algo indispensável à própria inteligibilidade do FSM:

Em qualquer discussão analítica sobre o FSM, é crucial manter uma distinção entre o Forum Social Mundial e seus constituintes - movimentos sociais e redes. Eles agem dentro e para além do FSM mas também constituem o FSM como evento e como espaço. O FSM é ao mesmo tempo mais e diferente da soma desses movimentos; e os movimentos são mais e diferentes do que a soma de suas práticas vis-a-vis o FSM. O FSM e seus movimentos constituintes tem todos suas próprias praxes particulares em evolução (Conway, 2008).

Essa disposição, a que a autora faz questão de aderir, está contida na Carta de Princípios. Segundo essa lógica, ainda que façam parte do repertório de grupos participantes, práticas como manifestos, ações diretas, declarações, tomadas de posição, programas políticos ou confrontos com a polícia, não são se confundem com o processo Fórum, não dizem respeito a sua forma, mas

\footnotetext{
${ }^{19}$ Expressões de protesto e ação direta fazem parte dos Fóruns Sociais Mundiais desde seu início. Em 2001, durante o primeiro FSM e Porto Alegre, um grupo de jovens apontados como punks e anarquistas, contrariando as orientações da organização, tentou ocupar uma loja McDonald's no dia da abertura do evento. Mais tarde, ativistas da Via Campesina, entre os quais o líder antiglobalização francês José Bové, invadiram campos da transnacional de insumos agrícolas Monsanto para protestar contra os produtos transgênicos "em defesa da pequena agricultura" (AGÊNCIA FOLHA, 26.01.2001). No entanto, aspectos de institucionalização e hierarquia aparecem de forma muito mais pronunciada no Fórum Social Mundial do que nas manifestações de rua. Chegaram a ocorrer, também desde os primeiros anos, protestos dirigidos às próprias contradições internas do Fórum Social Mundial (Di Giovanni, 2002, "Entrevista". In: Cevasco; Leite; Loureiro, 2002).

${ }^{20}$ As oficinas costumam designar reuniões menores e participativas, entendidas frequentemente como escape ao formato da audiência passiva encontrado em palestras e conferências. Voltaremos a esses termos no segundo capítulo.
} 
apenas aos sujeitos autônomos que ali se reúnem. Da mesma maneira que confere autonomia a suas "partes", o Fórum em si se autonomiza, passando a ser tratado, na análise de Conway como nos debates do Conselho Internacional, como um sujeito por conta própria, sobre quem ninguém parece ter poder.

\section{A estratégia e seus usos}

Ainda que a noção de estratégia seja central nas práticas discursivas que constroem o FSM como espaço e como processo, como vimos, o seu sentido de definição de um lugar de poder tornase pouco visível, na medida em que a constituição explícita de qualquer espaço passível de disputa é interdita no FSM. Define-se que todo espaço deve permanecer aberto, embora o espaço aberto do FSM seja reconhecidamente um espaço regulado: regulado de modo explícito por uma Carta de Princípios e em função de procedimentos político-administrativos; e regulado de forma implícita por atribuições de valor e hierarquias. A existência dessas formas de regulação, visíveis e ocultas, está intimamente ligada ao sentido (pro)positivo que lhes é atribuído, à percepção difundida por diversas análises e balanços de que ele representa um "avanço" com relação às práticas de protesto e oposição ao neoliberalismo em geral ou ao Fórum de Davos, especificamente, que o antecederam o FSM e que seriam por ele requalificadas.

A forma Fórum Social confere assim um recorte particular aos problemas da heterogeneidade organizativa, ideológica, geracional e geográfica que atravessam as práticas características do movimento anti-globalização (Azzi, 2007; Di Giovanni, 2012). O motivo mais evidente que o Fórum Social Mundial toma emprestado dos protestos antiglobalização é a "unidade na diversidade". No contexto dos protestos de rua, no entanto, este não é um princípio abstrato, mas a forma concreta da ação, uma tática: prática coletiva imediata que possibilita, embora não garanta, que deslocamentos comuns - o cerco a uma reunião do Fundo Monetário Internacional ou do G8, por exemplo - sejam compostos por inumeráveis movimentações e fórmulas gestuais (Di Giovanni, 2012).

No caso do Fórum Social Mundial, a convergência dos diferentes perde seu caráter tático e ganha sentido abstrato: sua matéria não é mais a força dos corpos na rua, mas o universo de princípios e regulamentos que colocam o "espaço aberto" em operação. A diversidade é assumida como um dado e tão naturalizado que, como sugere Santos (2005), do ponto de vista de sua lógica interna, fica difícil entender o que se está a excluir. Na medida em que o Fórum de Porto Alegre é amplamente entendido como um momento distinto do contexto de protesto, falar em "unidade dos diversos" não é apenas uma reiteração, mas uma transformação significativa do que este mote representa. Como já notou Rodrigo Nunes, a inovação tática que caracterizou os protestos ditos 
antiglobalização, conhecida como "swarming" - ou "de enxame" - em que a multiplicidade de iniciativas autônomas toma a forma de uma ação unificada, exigia um alvo singularizado e de alguma maneira pré-determinado. O autor afirma:

$\mathrm{Na}$ ausência de um [alvo] que esteja dado externamente, tal como uma reunião de cúpula que, por alguns dias, pode fisicamente assumir a posição de um inimigo comum - a questão simplesmente se abre de novo: como pode uma constelação muito diversa de forças sociais determiná-lo? (Nunes, 2009, p. 5).

A diversidade como princípio, "enquanto é efetiva em uma situação de swarming, tem pouca utilidade na definição de objetivos" (Idem). É em nome deste princípio que a definição de objetivos torna-se, no FSM, uma prerrogativa de seus participantes autônomos, ao mesmo tempo em que se torna proibida para o "Fórum enquanto Fórum". Todos podemos tomar decisões coletivas, mas fica vedada a possibilidade de que tomemos decisões coletivas todos juntos. Segundo a Carta de fundação:

@ s participantes não devem ser chamad@s a tomar decisões, por voto ou aclamação, enquanto conjunto dos participantes do Fórum, sobre declarações ou propostas de ação que@s engajem a tod@s ou a sua maioria e que se proponham a ser tomadas de posição do Fórum enquanto Fórum (Carta de Princípios do FSM, 2001).

$\mathrm{Na}$ história do Fórum Social Mundial busca-se, ao menos internamente, eliminar o problema - tão velho quanto desagradável - de que também fala Nunes: "toda determinação, toda declaração do tipo 'essa é nossa posição', 'isso é o que temos que fazer agora', reduz os termos do debate e, portanto, (pelo menos em princípio) exclui as pessoas que pensam diferente" (op. cit.). Concebe-se o FSM como uma espécie de área de preservação das diferenças e de sua proliferação, um espaço a salvo da disputa de poder, ao mesmo tempo em que a operação desse espaço exige decisões e exclusões. A própria Carta de Princípios21, na medida em que previne a possibilidade de que alguém convoque uma tomada de posição em nome do FSM, tacitamente desmascara "a ingenuidade, talvez insidiosa, de se presumir que um espaço aberto é um espaço sem luta, desprovido de política e de poder" (Biccum, 2005, p. 127).

A esse descompasso entre a presumida "abertura" a priori do Fórum e a evidência das cisões que ele mesmo produz, April Biccum dá o nome de "ambivalência do espaço aberto". A descrição

\footnotetext{
${ }^{21}$ Importante notar que a Carta é um documento continuamente reativado ao longo das edições do Fórum. A partir do FSM 2004, em Mumbai, a adesão formal à Carta de Princípios é integrada ao mecanismo de inscrição dos participantes e entidades: só se pode completar o processo via Internet tendo aceito explicitamente as condições da Carta.
} 
da autora sobre o Fórum de 2004, em Mumbai, certamente soará familiar a quem tenha participado das edições do Fórum em Porto Alegre:

Enquanto de um lado havia um desconcertante e maravilhoso leque de diversidade cultural, comunicação intercultural, interação e intercâmbio apesar das barreiras de idioma (recebi numerosos beijos e abraços de mulheres e meninas) e liberdade de expressão para quase qualquer tema político conhecido, havia uma desconcertante estratificação de riqueza e prestígio, manifestada particularmente em termos das acomodações (hotéis de cinco estrelas para alguns participantes, acampamentos do lado de fora dos locais para outros) - eu e minha colega tivemos a sorte de ser hospedadas por amigos (Biccum, 2005, p.123).

Por um lado, aberto e horizontal, por outro, fechado e estratificado; ao mesmo tempo "problematicamente hierárquico" e "politicamente produtivo em sua espontaneidade" (Biccum, 2005, p. 122), o dito novo modo de fazer política do Fórum Social Mundial convive com sua sombra. Essa ambivalência atravessa a produção textual que estamos analisando na forma de debates contínuos sobre a natureza do Fórum, cercados de mal dissimuladas ansiedades: movimento ou espaço? Ator ou arena (Teivanen, 2004)? Estrutura organizativa ou processo?

A "cultura política" do FSM, o espaço imaginado como uma ampla mesa dedicada ao diálogo e ao congraçamento, é sabidamente assombrada pelos demônios do aparelhamento, cooptação, dirigismo, do controle, da manipulação e do autoritarismo. A respeito dessas forças misteriosas, Francisco Whitaker constrói a seguinte ilustração:

Mas efetivamente tudo se passa como se debaixo da mesa sobre a qual se desenham as ideias para a organização do Fórum Social Mundial, ou se apóiam os cotovelos para ouvir com atenção outras ideias que vão sendo propostas, estivesse escondido um enorme polvo. Alimentado pelas práticas do "velho mundo", seus longo e fortes tentáculos reaparecem continuamente de todos os lados da mesa, tentando puxar para baixo tudo que se tenta criar de novo (Whitaker, 2005, p. 24).

A narrativa prossegue advertindo sobre as astúcias desse monstro sem rosto ou nome, que busca impedir que cresçam e prosperem as criações dos arquitetos-ouvintes do Fórum e faze-los sucumbir às práticas que o autor qualifica como "velhas", mas que na cena estão escondidas, presentes, e não ultrapassadas.

A passagem poderia ilustrar com eloquência a tensão do gesto estratégico "em um mundo enfeitiçado pelos poderes invisíveis do Outro" (De Certeau, 1980, p. 59). Mas o Outro, na parábola de Whitaker, não é no entanto um inimigo externo, é uma presença (misteriosa, talvez porque não se queira dar nomes aos polvos) que atua dentro do espaço criativo comum. Escondido embaixo da mesa, o avesso do espírito diplomático do próprio Fórum surge na figura de uma ardilosa força 
tentacular, sobrevivente do "velho mundo" em que a ação política emancipatória era obrigada a navegar os mares do conflito, da violência e das relações de dominação.

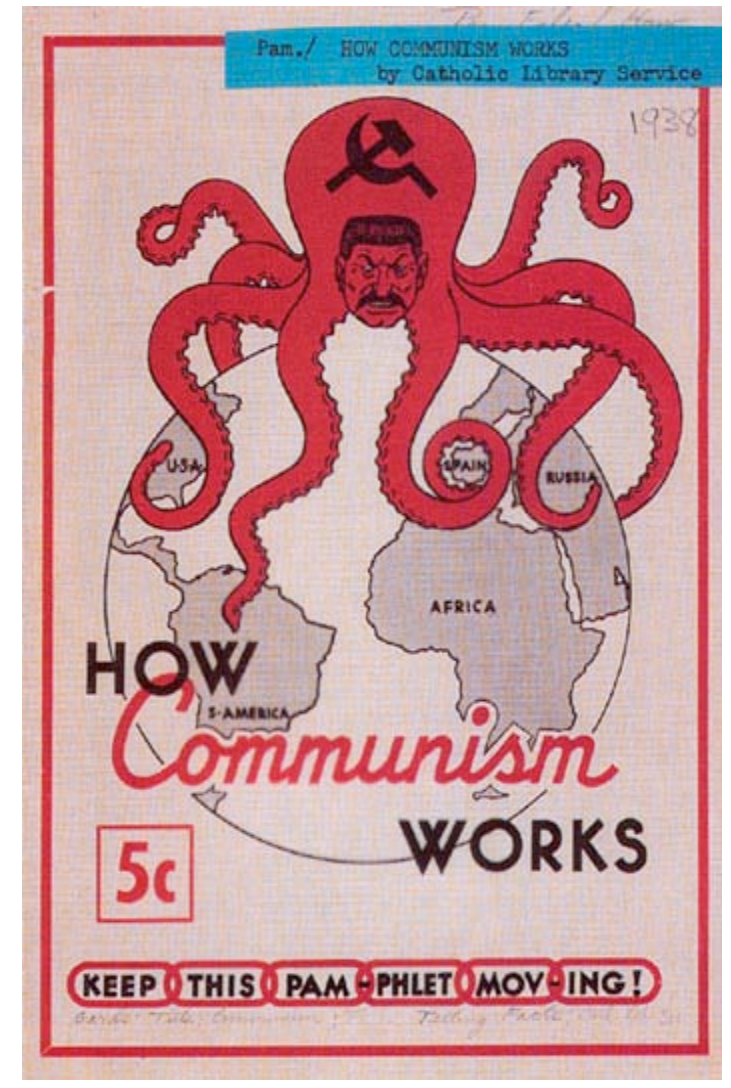

Figura 1.1

O polvo, imagem escolhida por $\mathrm{F}$. Whitaker para representar as ameaças ao bom funcionamento do método FSM, é um importante tropo da cartografia e da charge política pelo menos desde a segunda metade do século XIX. Surgindo para ilustrar as tensões crescentes entre estados que levariam a eclosão da I Guerra Mundial, o animal se torna emblema do mal que se alastra no espaço: "sua cabeça feia está no centro de uma inteligência maléfica que manipula seus apêndices obscenos", explica o cartógrafo Frank Jacobs. O "emblema" que vemos aqui em um panfleto anticomunista estadunidense de 1938, segundo Jacobs, "é em si mesmo ideologicamente neutro, uma arma de aluguel para qualquer lado da disputa"(Jacobs, 2011).

O Conselho Internacional tem muito em comum com a mesa descrita por Whitaker. Ele é por excelência o espaço das discussões internas, definido por seu "papel protagonista na orientação das diretrizes políticas e na definição dos rumos estraégicos do FSM" (CI - Caráter, responsabilidades, composição e funcionamento, 2001). Desde sua criação, fica estabelecido que assim como o processo que deve facilitar, o Conselho Internacional "não se constituiu em instância de poder e nele não haverá mecanismos de disputa de representação" (Idem). Não é desejável, segundo essa regra, encontrar em uma de suas reuniões alguma pretensão de representação, poderes 
e disputa: deliberação sobre qualquer tema só pode ser concebida a partir do consenso ${ }^{22}$, o que enfatiza o caráter reflexivo e diplomático do tipo de envolvimento político exigido de seus membros, assim como dos participantes do Fórum em geral. Também acerca do conselho, há tensões e mistérios não resolvidos. Uma piada incluída na transcrição do debate "O Futuro do Fórum Social Mundial", realizado durante o Fórum de 2005, fala também de um fantasma. Facilitador do debate, o já citado sociólogo Teivo Teivanem, membro do Conselho Internacional, convida os demais membros presentes a responder à uma pergunta:

Alguém quer responder a isso, eu posso responder, não, eu quero responder. É como alguém disse, que estar no Conselho Internacional [risos] ... estar no Conselho Internacional é como estar no Comitê Central sem saber quem é o Stalin! [risos] (Caracol Intergalactika, 2005, p. 162).

Os membros do conselho parecem reconhecer uma força que governa suas atividades, mas que não se revela ou toma forma de um ator particular. Qualquer de seus membros pode eventualmente ser o tirano que ninguém é capaz de identificar. Michael Albert, que participa de uma reunião do Conselho na categoria de observador, também se vê incapaz de localizar a fonte de decisões importantes:

E não é que as pessoas na mesa não quisessem uma abordagem mais democrática e participativa. Esse desejo foi expressado várias vezes. Mas depois de algum tempo na reunião, tornou-se óbvio que apesar da estatura e dos desejos dos membros, as pessoas no Conselho e na mesa não eram o locus real do poder no FSM. (...) Quem decide se vamos ter um evento com a presença de Lula e qual será seu tamanho? E Sobre Castro, ou Chavez? Haverá exclusões? Com base em quê? E os Zapatistas? (...) Qual conteúdo será parte dos eventos centrais e qual conteúdo vai ficar na periferia? Quem vai ter a passagem paga e quem não vai? (...) Qual vai ser a acomodação entre a defesa de uma reforma do sistema capitalista e a defesa de um sistema inteiramente novo? (Albert, 2006, p. 364).

A realização dos eventos e das própria reuniões do Conselho estão evidentemente apoiadas em uma série de decisões práticas e políticas que mobilizam estruturas organizativas diversas. Recursos são alocados, espaços e tempos são distribuídos entre participantes segundo critérios que não podem ser descritos como igualitários. Onde está esse poder de organizar o próprio Fórum, se não está visível na operação do Conselho? Parece por um momento que Michael Albert concordaria com Whitaker sobre haver algo se movendo embaixo da mesa. Mas não se trata, como sugere a cena do polvo, da infiltração de uma força externa, que desfaz as invenções do Conselho. É a

\footnotetext{
${ }^{22} \mathrm{O}$ documento "Esclarecimento dobre os princípios que orientam a organização do Fórum Social Mundial" (2002) destaca o sexto ponto da Carta, segundo o qual "o fórum não se constitui em instância de poder" para esclarecer "o caráter não deliberativo.
} 
própria vida política do Conselho Internacional, ou do processo Fórum como um todo, que parece estar apoiada em um duplo, um universo paralelo onde certamente há algo a ser deliberado e há poderes para fazê-lo, e poderes, quem sabe, a ser disputados.

Como lembra Steffen Böhm (2005), importantes decisões organizacionais são tomadas pelo Conselho Internacional e pelos vários comitês organizativos em nome dos participantes, havendo portanto uma forma política representativa, que envolve poderes e hierarquias, em plena operação. O "problema", argumenta o autor:

é que essa representação frequentemente não é reconhecida ou problematizada nem por aqueles que estão tomando as decisões nem pelos participantes frequentemente reivindicando-se "horizontais" - que veem o FSM como um espaço totalmente aberto [...] Não, não é um espaço completamente aberto. O FSM é em certa medida um espaço fechado no sentido de que há pessoas tomando decisões sobre a forma como as coisas são conduzidas: quem financia o Fórum? Quem constrói os espaços necessários? Quem fornece a comida e de que maneira ela será produzida? Que palestrantes serão convidados? O que será publicado no web site? Onde o próximo FSM vai acontecer? Que tecnologia será utilizada? Esses são talvez temas organizativos mundanos, mas são intensamente políticos ao mesmo tempo [...] (Böhm, 2005, p. 143).

Sendo ostensivamente aberto em termos de seus princípios, o Fórum é fechado no que tange os processos decisórios mais corriqueiros. Essa segunda dimensão, no entanto, não se torna facilmente objeto de problematização. As experiências relatadas por Michael Albert (2006) e April Biccum (2005, p. 122) também falam de uma bifurcação das dinâmicas políticas no FSM: há uma separação entre a concepção anti-estratégica e horizontalista do Fórum (depositada na Carta de princípios, desenvolvida em diferentes abordagens teóricas e celebrada nas reuniões do Conselho Internacional) e os processos de negociação/decisão que definem com quem, quando, onde e como seus eventos anuais e suas instâncias permanentes se realizam. A defesa veemente das diferenças internas, da pluralidade e da horizontalidade, recorrente na produção textual que analisamos, tornase, à revelia das boas intenções de seus autores, um mecanismo de encobrimento das lógicas particulares que informam essas escolhas e das relações - de poder, certamente - que se estabelecem entre participantes e organizadores.

Além de articular análises e balanços, cercada de ansiedades e constrangimentos, a questão da estratégia no Fórum Social Mundial aparece também imbricada no campo de disputas pouco visível, mas não pouco importante, que envolve as decisões ditas operacionais ou relativas ao seu funcionamento. Aproveitando mais uma metáfora sugerida por F. Whitaker: sendo o fórum-espaço uma "praça", é necessário que haja pessoas e instituições que desempenhem a tarefa de "organizar o uso da praça sem interferir no que está sendo discutido dentro dela” (Whitaker, 2009, p. 93). Parece, 
afinal, que há, fora da praça ou embaixo da mesa, um trabalho a ser feito. A separação entre regras de uso e o sentido político do processo, é tomada por Whitaker como fundamento do FSM, assim como a separação entre o "Fórum em si" e as ações de seus participantes. A disposição estratégica que devemos notar não se dá, ao menos em princípio, como cercamento da praça ou exclusividade da mesa, e sim como modo de estabelecer uma certa ordem sobre os usos que se pode fazer delas. Como aponta April Biccum: "o que se torna importante, e aquilo que precisamos ter em mente com vigilância é, não apenas que existe um espaço, mas como e para quê o espaço para mobilização e resistência é usado" (Biccum, 2005, p. 127) ${ }^{23}$.

O problema dos usos do espaço permite lançar luz sobre o universo das escolhas de caráter “operacional" que, em um plano político aparentemente paralelo ao discurso da horizontalidade, confere à nova forma de fazer política associada ao FSM sua margem de manobra. Trata-se dos objetivos e lugares de poder articulados fundamentalmente pelas práticas de organizadores: membros das instâncias de decisão menos visíveis, comissões, comitês e funcionários vinculados à realização dos eventos. É aqui que aparece a hierarquização de temas e participantes, a distribuição de recursos e a distribuição das atividades no espaço, que culmina na transformação da própria noção de estratégia na noção de metodologia.

Por metodologia entende-se as definições que dão forma aos eventos e ao processo-fórum: ela compreende as regras e tipologias que definem a participação de entidades, a inscrição de diferentes categorias de atividades, os tópicos de discussão e o modo como os resultados dessas atividades são postos em circulação. No plano das disposições metodológicas são construídos os desenhos estruturais que se repetem e transformam para criar vínculos entre a realização pontual dos eventos no tempo e no espaço e a sobrevivência do FSM enquanto "processo de reflexão estratégica coletiva" (FSM, Comissão de Metodologia, 2001). Não parece casual que no mesmo momento em que se constitui a Comissão de Estratégias, seja criada a Comissão de Metodologia do Conselho Internacional, responsável por propor a formulação dos temas estruturantes e o desenho conceitual das atividades do Fórum. Dada a centralidade da incumbência, esta comissão torna-se permanente, constituindo um dos pontos de articulação mais importantes do processo FSM e sendo tema de alguns dos debates mais acalorados que tive oportunidade de acompanhar. Apesar da composição da Comissão não ser fixa, alguns participantes, todos representantes de entidades membros do CI, permanecem ativos desde o início. Trata-se de fato de uma comissão em que as entidades envolvidas na fundação do Fórum no Brasil tiveram papel proeminente.

\footnotetext{
${ }^{23}$ Tradução minha, ênfase em itálico do texto original.
} 
Ao longo do primeiros cinco anos de realização do FSM, a metodologia, também chamada nos documentos de "arquitetura do processo Fórum", é uma dimensão crucial de sua produção como totalidade política. Ela define muitos dos critérios cuja lógica pode parecer escondida a observadores da movimentação mais ruidosa de atores e mensagens na praça do FSM. No próximo capítulo, voltaremos à metodologia, buscando entender as operações em jogo nesse universo.

É possível encontrar ainda outros usos da noção de estratégia quando se trata de definir sujeitos e dinâmicas de poder no interior do "espaço Fórum". Ela se faz presente nas falas que não têm registro e na forma como as pessoas discutem e descrevem a complexidade das relações de aliança entre as entidades participantes. Como me explicou, em 2011, um militante a quem perguntei sobre as relações de seu movimento com outros movimentos e organizações ativas no FSM, a estratégia pode ser entendida "como uma cebola, por camadas". Segundo ele, as alianças mais densas e importantes constituem o seu núcleo, em que algo precioso é compartilhado. Neste nível, a estratégia figura ao lado de outras, como noções derivadas de aliança estratégica e de confiança, exercendo papel importante na definição de diferentes densidades de relação política, associadas a diferentes graus de afinidade entre grupos e indivíduos participantes.

Essa outra poética da estratégia que encontramos no registro de tais relações, embora atravesse toda a preparação de atividades e desdobramentos dos Fóruns, expressa-se em modos de dizer muito diferentes da linguagem estabelecida pela metodologia e, muitas vezes, parece alheia às categorias analíticas que os textos de balanço e interpretação dos rumos do Fórum trabalham para construir. A julgar pela experiência de participação no Fórum como ativista, no campo particular das alianças em torno da Assembléia dos Movimentos Sociais ${ }^{24}$, é possível afirmar que muitos coletivos e indivíduos que tomam parte dos Fóruns Sociais ocorridos em Porto Alegre, e participam de suas instâncias organizativas não veem a ênfase na horizontalidade ou na construção de uma arquitetura metodológica como condição indispensável para que o Fórum seja uma unidade ou um processo. A realização deste processo, para muitos militantes de movimentos sociais, é impensável se não se levar em conta que os coletivos, organizações e movimentos participam dele tendo em vista prioridades particulares, derivadas de dinâmicas que antecedem e ultrapassam os limites do Fórum Social Mundial. Na perspectiva daquilo que porta-vozes de algumas entidades chamariam de “dinâmica real dos movimentos e lutas sociais" (Egireun e Nicholson, 2004, p. 94), a estratégia não se confunde com a metodologia, mas dela se afasta na medida em que aponta sempre para necessidades, objetivos e confrontos que extrapolam a arquitetura interna do processo Fórum e sua reprodução. Essa contradição entre a consolidação de uma lógica interna do FSM e a estratégia

\footnotetext{
${ }^{24}$ O papel da Assembleia dos Movimentos Sociais e as tensões produzidas por essa iniciativa no interior do FSM são detalhados do trabalho de Diego Azzi (2007).
} 
tomada como razão e ação dos movimentos sociais em um mundo exterior a ele chega a converterse em um "peso", como afirmam Paul Nicholson, então coordenador da Vía Campesina europeia, e o sindicalista basco Josu Egireun, em um balanço publicado após a realização da quarta edição do Fórum, em Mumbai:

Atualmente, o critério de realização anual dos fóruns, onde estão constituídos, resulta em uma carga insuportável para os movimentos sociais (justo quando o papel dos mesmos é facilitar seu desenvolvimento) e só pode satisfazer aqueles que vivem de, por, e para os fóruns (Egireun e Nicholson, 2004, p. 97).

O atrito entre uma estratégia entendida como relação que precede a constituição do Fórum e a estratégia interna, que atribui primazia ao florescimento da diversidade ou à consolidação do Fórum-como-método, acirra-se ao longo dos anos de Porto Alegre e não parece ter desaparecido com o espaçamento da periodicidade e a rotação dos locais de realização dos eventos - mudanças metodológicas implementadas após 2005. Durante o FSM realizado em 2011, em Dacar, José Miguel Mederos, membro do Conselho Internacional em representação do Comitê que reúne as organizações cubanas participantes do Fórum, atualiza este conflito em um artigo dirigido à Comissão de Metodologia:

As reiteradamente cambiantes formulações e estruturas metodológicas que se vem aplicando ao processo fórum e seus momentos de encontro estiveram cheias de críticas e insatisfações por parte daqueles que são protagonistas diretos das lutas sociais. Ainda que seja justo reconhecer aí acertos e desacertos, segundo seu grau de desenvolvimento, suas necessidades de luta e suas possibilidade de resistência, enfrentamento e capacidades de construir alternativas, para alguns o estado atual de desenvolvimento do processo resulta suficiente; para outros, cujas exigências são maiores, não (Mederos, 2011, p. 2)

Para Mederos, a metodologia não pode operar senão como ferramenta, em função de objetivos definidos por exigências "maiores". Trata-se de uma estratégia concebida nos termos da luta de classes e da permanente batalha contra as reconfigurações do sistema capitalista, cujos recortes precisam responder "aos tempos que se vive" (Idem). Diferente da centralidade que lhes é atribuída em outras análises, as soluções de caráter metodológico são percebidas aqui como superficiais, alheias aos domínios da estratégia, a um só tempo mais íntimos e mais abrangentes: "como tentar curar uma afecção profunda com aplicações cutâneas, quando sua origem está na estrutura óssea" (Idem).

O "quê" é afinal a estratégia, ou "qual" é a estratégia do FSM, deixam de ser perguntas relevantes, já que toda a densidade da noção que discutimos aqui, indica que seu sentido depende de um “como". Os usos de um espaço ou de uma noção são tão ou mais importantes politicamente 
quanto os princípios de sua fundação. O mesmo vale para a o problema da construção do sentido unitário do FSM. A constituição da unidade política do Fórum não é dada por uma forma homogênea e abrangente da análise política que orienta as ações coletivas e lhes confere sentido comum, à maneira do que poderíamos conceber como um "Espírito de Porto Alegre". Tampouco trata-se de uma unidade estabelecida sobre tabula rasa, em que se dissipam quaisquer relações de poder "velhas" em favor de um mundo político "novo" em que estaríamos prontos a começar do zero. Finalmente, não seria possível entender essa unidade se dela não participassem as diferentes densidades das relações de aliança. Na medida em que compreende todas essas suas formas particulares e as tensões e contaminações existentes entre seus diferentes usos, é que a estratégia participa da constituição do Fórum Social Mundial como uma unidade processual e espacial, na qual é possível engajar-se e reconhecer uma certa experiência política.

É preciso dizer ainda que os lugares de poder e os sentidos da política produzidos nesses usos não são redutíveis ao resultado mecânico de uma negociação, ou, para usar o vocabulário militante, não são o simples reflexo de uma economia de "correlação de forças" ou disputa de poder simples entre formas concorrentes. Do ponto de vista da complexidade de "maneiras de dizer" e “modos de fazer", os usos da estratégia são, como vimos, profundamente contraditórios, mas ao mesmo tempo permeáveis uns aos outros. Ainda que seja tentador separar em times opostos os que usam um mesmo termo com um ou outro sentido, para assim poder discutir os resultados do jogo, procurei mostrar como os discursos do FSM considerado como um sujeito, as críticas e apologias dos acadêmicos engajados, a linguagem das alianças e os arranjos operacionais definidos pelos organizadores, entre outros saberes-fazeres, não são domínios independentes.

Levando em conta o conjunto vivo dos diferentes usos da noção de estratégia no contexto do FSM - tarefa a que se dedicou este capítulo - é possível dizer que, além de um conceito, ela é a marca de um gênero de enunciação. Sendo recusada como categoria de uma política "velha" e impositiva, mantida na distância segura do horizonte, como estação futura de um caminho em que não vale a pena se apressar, ou remetida estritamente ao plano das ações autônomas das entidades que não se deve confundir com o FSM em seu conjunto - a estratégia é um modo de falar sobre o saber e o poder, de indicar com maior ou menor discrição a presença de sujeitos de poder.

No contexto do Fórum Social Mundial, a estratégia é também um sinal de perigo, que apresenta um problema bastante complexo: como se fala do poder neste "outro mundo"? Como se fala do poder em um mundo onde a enunciação de objetivos, prioridades ou identidades é considerada uma ameaça, onde a enunciação de um sujeito unitário ou a constituição de um locus de poder lançaria todos no abismo das disputas, a mercê de monstros arcaicos, colocando tudo a perder? Para ampliar a compreensão desta questão, será necessário voltar, a seguir, a algumas 
transformações notáveis da estratégia e dos dilemas que ela designa no interior do processo FSM: vamos analisar como se constitui o projeto ambicioso de uma instância de regulação ou facilitação considerada independente de sujeitos de poder, em um capítulo cujo motivo condutor será a noção de metologia. 


\section{Metodologia e arquitetura do espaço Fórum}

Como um espaço comum a todos, ele não fala, ou melhor, ele fala muito através de sua própria existência.

Francisco Whitaker ${ }^{25}$

No capítulo anterior, perguntamos pelos critérios que orientam decisões operacionais sem as quais o processo político não existiria, mas que são pouco visíveis em um espaço que se quer horizontal e não deliberativo. A metodologia é a rubrica sob a qual se inscrevem estilos de organização e práticas diretamente ligadas a essa dimensão operacional. Nos documentos de metodologia e nos desenhos que esses documentos definem para a programação dos eventos é que o Fórum de fato constitui um "outro mundo", regido por lógicas, saberes e poderes particulares. No campo das análises e balanços, a metodologia também é um tema privilegiado, objeto de contínuas teorizações. Esse termo diz respeito, em primeiro lugar, à definição da forma dos eventos do FSM, adquirindo também expressão importante nas formas como a programação dos eventos ocupa e transforma o espaço da cidade de Porto Alegre. A noção de metodologia é, portanto, incontornável para continuar explorando as práticas pelas quais a experiência política do Fórum Social Mundial adquire sentido.

É possível acompanhar como a metodologia do Fórum se transforma e adquire importância ao longo dos anos através da análise de uma seleção de documentos do processo Fórum, associados ao trabalho do Conselho Internacional do Comitê Organizador Brasileiro e de comissões criadas para o cumprimento de tarefas específicas, além alguns gráficos e fotografias produzidos a propósito da realização das diferentes edições do FSM em Porto Alegre. Esperamos mostrar como as formas da programação e de sua instalação no espaço expressam concepções particulares sobre a ação política, fundamentais para que se possa descrever e analisar a experiência do FSM.

Nos documentos oficiais do Fórum Social Mundial, define-se a metodologia como "critérios para a programação" dos eventos (FSM, 2002). O termo aparece também associado a uma "arquitetura" do Fórum: desenho estrutural que estabelece o vínculo entre a forma ocasional dos eventos, sua realização pontual no tempo e no espaço, e a sobrevivência do FSM enquanto "processo de reflexão estratégica coletiva" (FSM, Comissão de Metodologia, 2001). José Correia Leite, representante da ATTAC no Cômite Organizador Brasileiro, atribui ao FSM 2004, realizado em Mumbai, o mérito de ter consolidado consensos sobre o método que confere ao Fórum o caráter

\footnotetext{
${ }^{25}$ Whitaker, 2009, p. 84.
} 
de espaço aberto estabelecido pela Carta de Princípios: "as regras do jogo, embora estranhas a certas culturas políticas, são cada vez menos questionadas" (Leite, 2004).

Assim, a metodologia do Fórum é entendida como um conjunto de regras e padrões de procedimento que pretende organizar o espaço político de forma "horizontal", "como uma praça pública que não tem dono" [...] "aqueles que sobem nas árvores não podem controlar de cima as ações dos que estão na praça" (Whitaker, 2009, p. 83). Mas, com argumentamos no capítulo anterior, mesmo o espaço definido como aberto, horizontal e não deliberativo, tem seus limites e normas de funcionamento - "Entrar nesse espaço implica a aceitação de sua Carta [de Princípios]." (Vargas, 2009, p. 187).

Publicamente responsáveis pelo traçado dessa arquitetura do evento são os membros da Comissão de Metodologia do Conselho Internacional do FSM, sempre em negociação com o conjunto do Conselho e com o Comitê Organizador Brasileiro. O produto final da atividade dos organizadores que se inscreve sob a rubrica da metodologia tem aspecto bastante formal: são listas de temas e categorias de atividades, como as que vemos no Anexo II, cuja ordem pouco ou nada revela sobre debates, eventuais conflitos ou modos de tomada de decisão implicados em sua elaboração. A programação, que deriva da combinação entre este trabalho dos organizadores na formulação de categorias e o mecanismo de inscrição de atividades pelos participantes, é, no entanto, um problema político de primeira grandeza.

Progressivamente, a partir de 2002, é na metodologia que os organizadores depositam boa parte das intenções de tornar o Fórum Social Mundial algo mais do que a mera soma de eventos espalhados no tempo e no espaço. Os padrões de montagem da programação, constituídos ao longo dos anos, são tidos como dimensão fundamental da relação entre os eventos e a preservação da integridade do Fórum como processo. Descartada a ideia de que o FSM se unifica em torno de um único programa de ação e pensamento à maneira de uma Internacional do século XXI, é principalmente sob o signo do método que ele será promovido a uma totalidade. Na metodologia é que se pretende que princípios de fundação sejam traduzidos em práticas, por participantes e organizadores.

Um documento de 2008, aprovado pelo Conselho Internacional em Copenhagen, explicita questões que começam a ficar claras para os organizadores já em 2003, quando o deslocamento do FSM para a Índia exigiu que as concepções de evento e processo se adaptassem a circunstâncias profundamente diferentes das encontradas em Porto Alegre nos anos anteriores: 
Dado que o FSM não é uma organização ou uma instituição com poderes e mecanismos de monitorização, investigação ou sanções, o desafio é: como difundir e aprofundar o processo FSM de uma maneira que não distorça a Carta de Princípios e mantenha os princípios básicos que o produziram? (FSM, 2008).

Este documento mostra-se um guia abrangente: vai de protocolos de colaboração entre organizadores e autoridades governamentais à relação entre o uso de equipamentos de ar condicionado e o aquecimento global. É apresentado como desdobramento e complemento dos princípios de fundação e, na terminologia cuidadosa do "espaço aberto", oferece indicações práticas, tratando do estabelecimento de controles e demarcações que permitem definir os contornos do FSM como tal.

Neste guia de 2008, entre as diretrizes para a realização de eventos FSM complementares à Carta de Princípios, define-se que os organizadores devem dotar o Fórum de métodos, para que este se realize como um "espaço físico e virtual de interconectividade horizontal de movimentos". Organizadores em qualquer lugar do mundo devem seguir as sugestões do documento, entendidas como condição para que cada evento que queira chamar-se Fórum Social seja vinculado histórica e intelectualmente ao processo-Fórum ${ }^{26}$. Na medida em que edições do Fórum multiplicaram-se pelo mundo e diversificaram-se as condições políticas, sociais e culturais de sua realização, a preocupação dos organizadores foi que um certo método seja fosse preservado. Para expressar a ideia de algo que mantém uma unidade, aplicando-se a diferentes objetos em diferentes circunstâncias, o documento de 2008 utiliza um termo mercadológico, ao qual voltaremos mais adiante: o FSM é uma "marca".

Outro elemento notável na centralidade da metodologia no FSM é a importância que o conceito ganha para alguns de seus intérpretes mais conhecidos, para quem a definição do Fórum como um espaço aberto é indissociável da constituição de sua metodologia. Entendido como uma "nova forma de fazer política", o Fórum Social Mundial é descrito em trabalhos como os de Leite (2003), Souza Santos (2005), Whitaker (2005) e Conway (2008), menos como um objeto e mais como um modo de fazer: um método original e singular que se distingue dos fenômenos políticos que o antecederam. A seguir, buscaremos analisar em que consiste este método e indagar em que sentido essas formas metodológicas vieram a ser consideradas a "verdadeira alma" do FSM.

\footnotetext{
${ }^{26}$ Em artigo recente, dirigido ao Conselho Internacional, Francisco Whitaker refere-se ao documento, sugerindo que sua aprovação teria tornado algo obsoleto o trabalho da Comissão de Metodologia, que "já quase não tem muito a dizer" (Whitaker, 2012).
} 


\section{Arquitetura do "espaço aberto"}

Levando a sério a centralidade da metodologia para organizadores e comentadores do Fórum Social Mundial, estamos de acordo com a proposição corrente de que ele não se define apenas a partir de ideias abstratas ou orientações ideológicas, mas é feito de uma série de mecanismos práticos, sem os quais os encontros periódicos e o engajamento permanente que produz não seriam possíveis. Como vimos nos documentos de fundação (posteriores à primeira edição de 2001), o FSM é definido como um espaço para a apresentação de propostas e perspectivas; a identificação de pontos de convergência entre organizações e redes; e o livre debate de orientações, campanhas e ações. Como expressa a Carta de Princípios, considerado como "espaço", e não como movimento, organização, grupo ou instituição, o Fórum Social Mundial não pode endossar deliberações, ações, expressões de posicionamento ou compromisso político que venham a ter lugar em seu interior. Isto equivale a dizer que, em tese, ninguém está autorizado a promover suas posições e propostas em nome do Fórum.

Já indicamos, no capítulo anterior, algumas contradições importantes dessa concepção: se o Fórum não constitui uma plataforma política comum, nem uma instância de deliberação, como são tomadas as decisões práticas através das quais esse "espaço aberto" é posto em funcionamento e toma a forma de eventos com centenas de milhares de pessoas? As decisões ditas operacionais nesse processo podem ser separadas de posicionamentos, compromissos ou da expressão de conteúdos políticos particulares? Buscamos aqui um ponto de vista para a observação de como funciona o "espaço" e em que ele consiste; uma perspectiva possível, não obrigatória ou definitiva. Para tanto, é necessário olhar mais de perto as regras e procedimentos implicados na realização dos eventos anuais - a metodologia - para analisar sua relação com a constituição do Fórum Social Mundial como totalidade processual, conforme colocamos em discussão no primeiro capítulo.

Em uma visita ao site oficial do Fórum (www.forumsocialmundial.org), ao percorrer as seções referentes aos encontros que aconteceram em Porto Alegre, notamos que, para além dos enunciados gerais organizados em torno da oposição ao neoliberalismo e da referência permanente à Carta de Princípios, a maior parte dos documentos ali arquivados para fins de registro e publicização do Fórum são os chamados "documentos de metodologia": textos que apresentam e justificam as normas, categorias e processos pelos quais coletivos e indivíduos inscrevem suas presenças no processo-Fórum. Se acessamos, no mesmo site, a seção "programação", o que vemos são documentos descritivos do mesmo tipo.

Segundo o documento divulgado pela comissão de metodologia do Conselho Internacional durante a preparação do encontro de 2003, "o sonho, a vontade e a emoção que dão vida ao Fórum" emergem através de uma estrutura de programação adequada, que seja capaz de "centrar" os 
trabalhos nas perspectivas e propostas do processo (FSM Comissão de Metodologia, 2002). Portanto, Entende-se que o espaço do Fórum Social Mundial precisa ser dotado de uma arquitetura própria aos propósitos descritos em sua Carta de Princípios: a reflexão, a disseminação dos resultados dessa reflexão, a formulação de propostas, a troca livre de experiências e a articulação para ações eficazes (FSM, 2001).

Desde a primeira edição, há diferentes modalidades de inscrição, geralmente associadas ao pagamento de alguma quantia de dinheiro, salvo nos casos em que a organização do Fórum decidisse subsidiar a participação de um movimento notoriamente popular ou de grupos considerados representativos de um segmento social desfavorecido. A inscrição de entidades, formaliza a participação de coletivos, grupos, instituições, associações e movimentos sem criar nenhuma tipologia interna de distinção: uma ONG, uma grande central sindical, um coletivo de artistas ou uma associação de bairro entram igualmente nessa categoria.

Nos primeiros anos do Fórum Social Mundial, este registro dava direito à inscrição de alguns delegados, indivíduos que participam do fórum como associados ou representantes de algum tipo de coletivo. As inscrições de delegados ou indivíduos (os últimos apenas a partir de 2002) garantiam, mediante o comparecimento no local anunciado nos dias anteriores e durante a realização do Fórum, o recebimento de um kit de participação, geralmente composto por uma bolsa de pano, um programa impresso contendo as indicações de horário e local de todas as atividades inscritas e um crachá de participante, que, segundo a determinação dos organizadores, poderia definir prioridades de acesso aos locais de atividade, pelo menos aos mais concorridos. As diferenciações de cor e formato dos crachás que nos primeiros anos diferenciavam participantes comuns, delegados, organizadores e convidados, tenderam também a desaparecer ao longo do tempo $^{27}$. A categoria delegados foi logo suprimida, igualando-se as formas de identificação da participação individual de qualquer tipo ${ }^{28}$, mas a distinção entre indivíduos e entidades permanece uma das regras de uso mais importante da metodologia do Fórum (Sen, 2009:175). Como me explicou uma antiga funcionária da Secretaria Executiva criada para cumprir as decisões do Comitê Organizador e operar a coordenação do Fórum, o encontro é concebido desde sua origem como um

\footnotetext{
27 Finalmente, as inscrições para veículos de imprensa e jornalistas permaneceram sempre diferenciadas, sendo realizadas através de um mecanismo próprio via Internet e de crachás de identificação distintos dos demais.

${ }^{28} \mathrm{O}$ primeiro Fórum não previa originalmente inscrições individuais. A procura de inscrições avulsas foi tão grande que não pode ser ignorada. Em 2001, as inscrições individuais foram realizadas por um grupo local mobilizado pela preparação do evento, que reunia representantes de organizações locais, estaduais e pessoas intensamente engajadas neste processo ainda que sem vínculo com alguma organização: o Comitê Gaúcho do FSM, que mediante o pagamento de uma quantia simbólica distribuiu crachás individuais com autorização do Comitê Organizador. Progressivamente, os participantes não formalmente vinculados a nenhum coletivo, bem como a receita gerada pelas cobrança de pequenas taxas individuais de participação foram incorporados às categorias de um processo centralizado de inscrições.
} 
espaço "da sociedade civil organizada": dedicado fundamentalmente a pessoas que já se encontram mobilizadas e agrupadas em associações, instituições, coletivos e movimentos de algum tipo.

Embora as participações individuais tenham sido incorporadas ao sistema de inscrições, até o presente, apenas entidades podem propor atividades nos encontros. Um indivíduo não "representa" ninguém, e portanto seu espaço de ação e sua voz no Fórum Social Mundial são limitados. Já as entidades são representadas na forma-Fórum como um estado social de engajamento e compromisso com processos coletivos, consideradas participantes legítimas, iguais em direitos e deveres, ainda que profundamente diversas quanto a formas de organização, capacidade de mobilização, acesso a recursos ou institucionalização. Entidades que formam parte de instâncias permanentes, como o Conselho Internacional (CI) e os Comitês Organizadores, também precisam se inscrever em cada evento, declarando sua adesão à Carta de Princípios.

Uma vez inscritas, as entidades são convocadas, anualmente, a propor atividades de debate, exposição e análise de propostas ou posicionamentos políticos; exibir questões e resultados de seus trabalhos e lutas particulares; fazer denúncias, expressar opiniões e apresentar soluções; relatar experiências, discutir formas de organização e muito mais. Todas as atividades inscritas (cujo número chega à casa dos milhares) devem ser então agrupadas e alocadas no espaço e no tempo de um evento de poucos dias - tarefa de extrema complexidade logística e política cuja execução fíca a cargo do membros do Comitê Organizador e dos funcionários do escritório do FSM. O resultado público e mais palpável deste trabalho são os cadernos de programação, folhetos contendo tabelas de locais, horários e temas, acompanhados de textos de orientação, traduzidos em diferentes idiomas para serem entregues aos participantes no início de cada evento. A partir de 2002, a secretaria do Fórum implementa um sistema de banco de dados simples, combinado a uma nova versão, mais extensa, dos formulários de inscrição das atividades a serem preenchidos pelo público participante através da internet. As ferramentas de organização de dados tornaram-se fundamentais no processamento de um volume cada vez maior de informação gerado pelas inscrições, mas, ao contrário do que podem fazer crer alguns documentos de metodologia, isso jamais significou a automatização do extenuante exercício de combinação e recombinação, sempre negociada individual ou coletivamente, que resulta na alocação final das atividades no espaço.

No momento seguinte à inscrição, em um processo intenso de comunicação entre representantes de organizações, membros do CI e CO e do escritório, os planos para as atividades se transformam e se desdobram, podendo ganhar proporções espetaculares (por exemplo, transmissão ao vivo por internet e TV, com tradução simultânea, em um ginásio para milhares de pessoas) ou ares de reunião privada (logo de manhã cedo, em uma sala discreta de um edifício comum). Formalmente, as possibilidades de combinação são ilimitadas. Iniciativas de proponentes distintos 
podem fundir-se para tornar visíveis relações de aliança. Redes de organizações, cujas perspectivas disputam consensos sobre certo tema, podiam deliberadamente propor atividades separadas, ainda que em formatos muito similares, para deixar claras suas distintas abordagens. Outras atividades, de naturezas a princípio muito distintas, podem revelar sua afinidade ao serem inscritas em um mesmo eixo temático, ou figurar no programa sob um mesmo título guarda-chuva, em horários separados, de modo a evitar expor cisões internas a um setor, coalizão ou movimento.

O desenho mais geral da arquitetura de um Fórum Social passa, desde sua primeira edição, pela definição de temas. Sendo um objetivo central promover a reflexão e o debate entre participantes, a primeira demarcação, vista como indispensável, é a formulação sintética dos assuntos a serem debatidos, relacionados à recusa de uma "globalização neoliberal" e à construção de alternativas a esta ordem nos mais diferentes aspectos da vida social, tal como estabelece a Carta de Princípios. Ao longo dos cinco primeiros anos de sua realização, os temas comuns formulados para o Fórum Social Mundial aumentaram em número e sua formulação tendeu a se tornar mais complexa, como podemos observar no temário incluído no Anexo B.

Em 2001, foram formulados pelo Comitê Organizador quatro eixos temáticos, considerados conceitualmente estruturantes dos diagnósticos do mundo atual, das possibilidades de um mundo diferente e dos meios para alcançar esta passagem histórica: "A Produção de Riquezas e a Reprodução Social”; "O acesso às Riquezas e a Sustentabilidade”; “A Afirmação da Sociedade Civil e dos Espaços Públicos"; "Poder Político e Ética na Nova Sociedade". As fórmulas são, em certa medida, didáticas e explicativas do mote "um outro mundo é possível”. Trata-se de indicar aos participantes deste evento inédito, a um almejado público externo e aos antagonistas identificados ao Fórum Econômico Mundial em Davos, a que veio a iniciativa do encontro. Indica-se que falar em outro mundo passa por certas palavras-chave e projeta-se um sentido de unidade no gesto de "enfrentar" alguns debates: sobre os modos de produção e de reprodução social; sobre questões de acesso a bens; sobre uma democracia que não se reduza ao Estado (afinal, partidos políticos e governos não participam do Fórum) e ainda sobre a moralidade, a espiritualidade e a natureza das relações de poder.

Estas fórmulas são definidas como eixos, sugerindo uma mecânica de rotação das iniciativas espontâneas dos participantes em torno de indicações temáticas propostas pelo Comitê. Cada eixo parecia poder exercer de maneira independente sua força centrípeta: em torno de cada um deles organizaram-se quatro conferências (dezesseis no total) e foram inscritas centenas de oficinas, sob responsabilidade das entidades participantes, para as quais a estrutura organizativa do FSM oferecia, essencialmente, uma sala e a divulgação no programa oficial de atividades. Entre as atividades previstas pelos organizadores, não estão diretamente associadas a esses eixos nem as 
atividades ditas culturais (apresentações artísticas de qualquer tipo), nem os testemunhos: palestras proferidas por intelectuais e militantes conhecidos internacionalmente sobre suas trajetórias, temas de atuação e questões globais.

A primeira modalidade que compõe a programação do Fórum são as atividades promovidas pelo Comitê Organizador (em anos posteriores, através de comissões e grupos de trabalho do Conselho Internacional), classificadas segundo diferentes funções, níveis de importância e expectativas de público. São conferências, painéis de debate ou testemunhos, que geralmente envolvem convidados nacionais e internacionais de grande notoriedade. Em particular, na primeira edição, o elenco de convidados, indicados como responsáveis pelo "aprofundamento" da reflexão, é das formas pelas quais se afirma a orientação política e o tom de contraposição ao Fórum de Davos. Até 2005 pelo menos, ainda era comum o interesse do público e da imprensa nessa escalação: “quem vai falar no Fórum deste ano?" Personagens famosos, como José Saramago, Eduardo Galeano, Augusto Boal ou Noam Chomsky, emprestaram frequentemente sua imagem pública, assim como suas análises e discursos, contribuindo para a publicização do Fórum Social, graças à grande escala de circulação de entrevistas e textos a respeito de sua participação no evento. De sua parte, as organizações e movimentos inscritos no Fórum eram convidados a propor oficinas, a segunda grande modalidade de evento a compor a programação do Fórum. São atividades concebidas como mais participativas, iniciativas de articulação entre entidades (a metodologia inclusive lhes reservava inicialmente o direito de realizar atividades não públicas), de tema mais específico e dedicadas a públicos menores.

Para o Fórum de 2002, várias mudanças foram introduzidas nessa metodologia. Descrevendo o Fórum como um processo de reflexão coletiva, o documento "Metodologia Programação do Fórum Social Mundial 2002" (2001) registra propostas encaminhadas pela comissão com vistas a responder "a questões que envolvem grandes desafios globais valorizando a diversidade e as múltiplas possibilidades de se construir um mundo melhor". Em geral, procura-se diversificar os formatos possíveis das atividades e sugerir certas funções a serem cumpridas por cada formato. Explicita-se que as conferências devem girar em torno da apresentação e construção de consensos sobre plataformas comuns das redes de movimentos e organizações da sociedade civil, articuladas para além do Fórum. Entre categorias de inscrição de atividade possíveis, "conferências especiais" foram criadas para apresentar resultados de encontros precedentes sobre temas circunscritos: são mencionados, no documento, a Declaração do Fórum Mundial de Soberania 
Alimentar, ocorrido em Havana ${ }^{29}$ e o Fórum Mundial da Educação ${ }^{30,}$ realizado em Porto Alegre. Já os seminários são dedicados ao "aprofundamento em torno de temáticas específicas", prioritariamente entre organizações integrantes do Conselho Internacional (Metodologia Programação do Fórum Social Mundial, 2001). Em grande medida, os temas destes seminários expressavam debates internos ao Conselho. O conteúdo destes debates foi cuidadosamente documentado, em colaboração com as instâncias organizativas do FSM, pelo trabalho de Thomas Ponniah e Willian Fisher (Fisher e Ponniah, 2003).

Em 2003, a proposta dos eixos temáticos é mantida: cada eixo é concebido como catalisador de preocupações, propostas e estratégias que já são desenvolvidas pelas organizações participantes do processo FSM. Os quatro temas originais se transformam em cinco, notavelmente incluído o assunto "Mídia, cultura e contra hegemonia": algo que busca demonstrar uma posição de maior centralidade do universo das manifestações culturais e artísticas (que apareciam como um mundo à parte na programação dos anos anteriores) e prover "espaço político" aos empreendimentos jornalísticos alternativos a que o Fórum deve a maior parte de sua projeção.

Neste terceiro encontro realizado em Porto Alegre, a concepção da metodologia procura incorporar também críticas que já começam a se fazer mais audíveis. No ano anterior, por exemplo, uma sala do Centro de Eventos da PUCRS destinada aos palestrantes convidados - equipada com ar condicionado e abastecida com copinhos de água mineral - fora ocupada por um grupo de ativistas, em um protesto festivo cujo lema era "somos todos VIP" e que visava "libertar" a água de suas embalagens plásticas (Di Giovanni, 2002, entrevista. In: Cevasco, Leite, Loureiro, 2002). A PUCRS, onde se concentravam quase todas as atividades dos Fóruns anteriores, era um espaço privado e considerado "elitista" por sua associação evidente a uma instituição de ensino também privada, algo que desagradava, em particular, o movimento estudantil gaúcho, mobilizado em nome da educação pública de qualidade e muito ativo na mobilização local para o FSM.

A partir de 2002, os organizadores começam a levar a sério a possibilidade de deslocamento de alguns polos de concentração de público na direção da Orla do Rio Guaíba, mais próxima ao centro da cidade, através do alto investimento em instalações temporárias de grande visibilidade. Esse deslocamento resulta de diferentes pressões para que o Fórum se espraie por Porto Alegre. Organizações e movimentos locais, cientes do impacto político e econômico do evento, demandam acesso mais fácil para a população de Porto Alegre, enquanto membros do Comitê Organizador e do

\footnotetext{
${ }^{29}$ Fórum realizado em Havana, Cuba, de 3 a 7 de setembro de 2001, cuja declaração final tornou-se uma referência importante para as campanhas conduzidas por organizações internacionais articuladas em torno do tema da Soberania Alimentar, termo introduzido pela Via Campesina Internacional nas ações de pressão sobre as políticas da FAO Organização das Nações Unidas para Agricultura e Alimentação.

${ }^{30}$ Encontro Internacional sobre Educação promovido em Porto Alegre nos dias anteriores ao FSM, impulsionado pelo Instituto Paulo Freire, organização brasileira que passa a integrar ao Comitê Organizador do FSM em 2005.
} 
CI consideram que a saída dos espaços da PUCRS tornaria o fórum mais popular e mais presente no espaço urbano.

A vitalidade política que a experiência do Acampamento Intercontinental da Juventude (AIJ) demonstrara em 2002, é também estímulo fundamental para esse deslocamento. Instalado em um parque público na mesma área da Orla, o Acampamento tinha sido um centro ruidoso e efervescente do Fórum fora da PUCRS: ali os debates e encontros se davam sem necessidade de paredes, cadeiras, equipamentos de som ou ar condicionado. Os acontecimentos do AIJ haviam sido apenas parcialmente incluídos no programa oficial, funcionando com um sistema independente de inscrições (Di Giovanni, 2002), recusando as regras que privilegiaram as "entidades" e restringiam ou desestimulavam a atuação dos indivíduos, e assumindo a participação das juventudes partidárias atuantes no movimento estudantil. Em 2002, o Acampamento é também a grande estrela da cobertura midiática do Fórum. O contraste entre a organicidade caótica da vida no acampamento e a estética acadêmico-empresarial do Centro de Eventos da Pontifícia Universidade Católica começa a deixar evidentes as contradições internas do FSM, na medida em que todos os procedimentos da organização são confrontados com o questionamento: “é este o outro mundo possível?”.

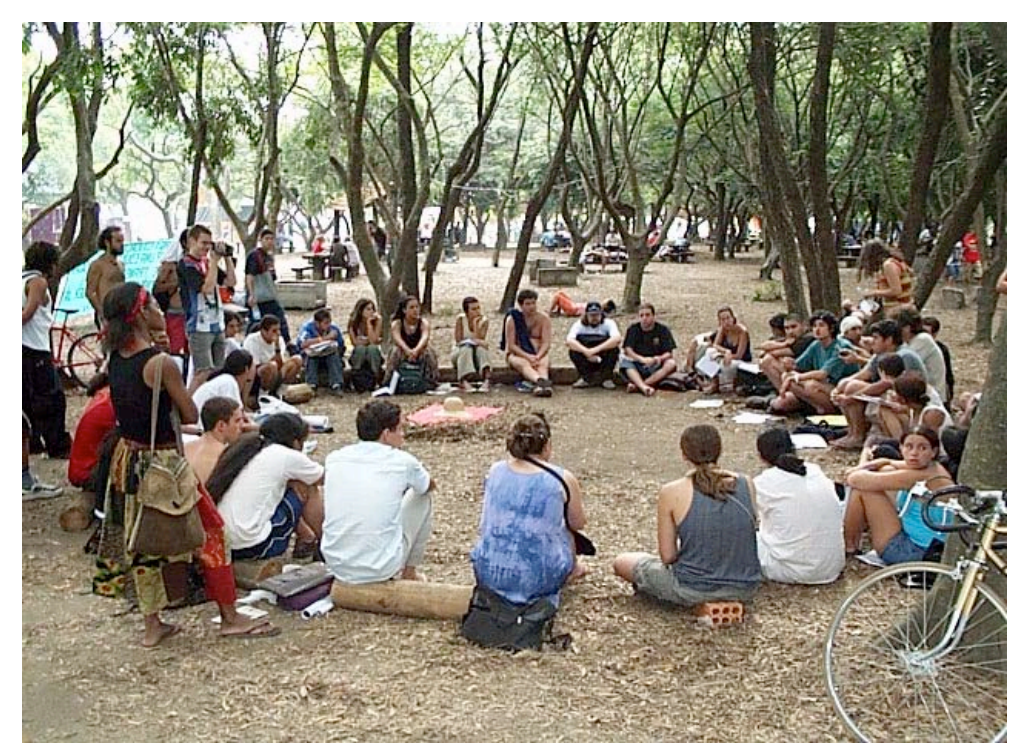

Figura 2.1

Reunião no Parque Harmonia - Acampamento da Juventude, 2002.

Fonte: http://www.wcams.com.br/fsm-poa_2002.htm 


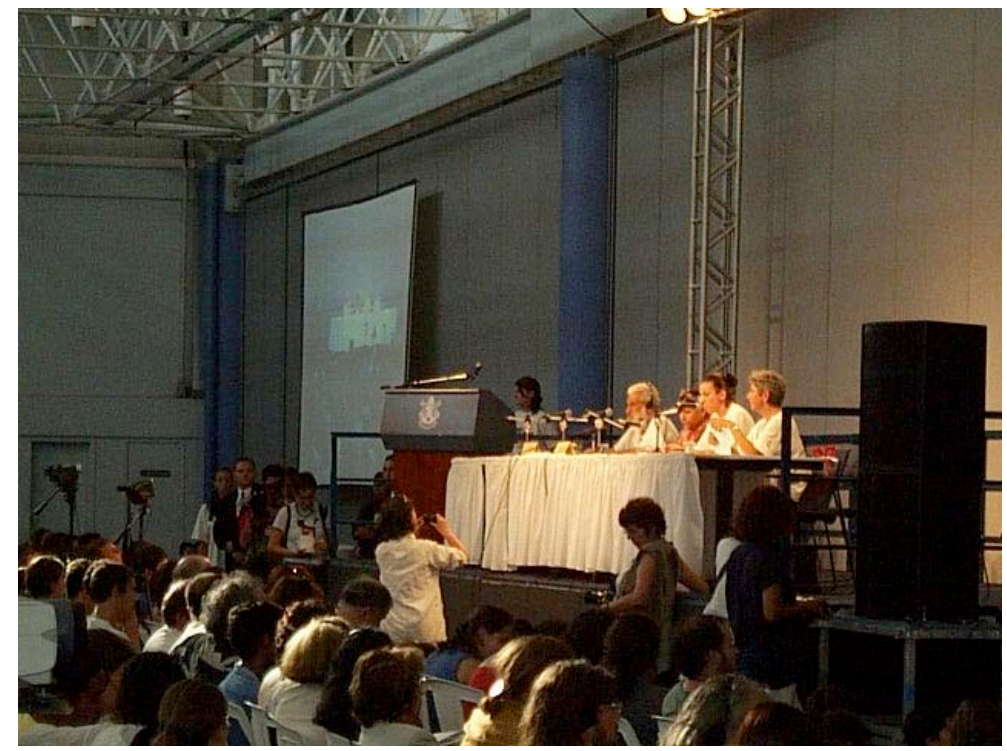

Figura 2.2

Atividade durante no Centro de Eventosda PUC-RS, FSM2002.

Fonte:http://www.wcams.com.br/fsmpoa_2002.hm

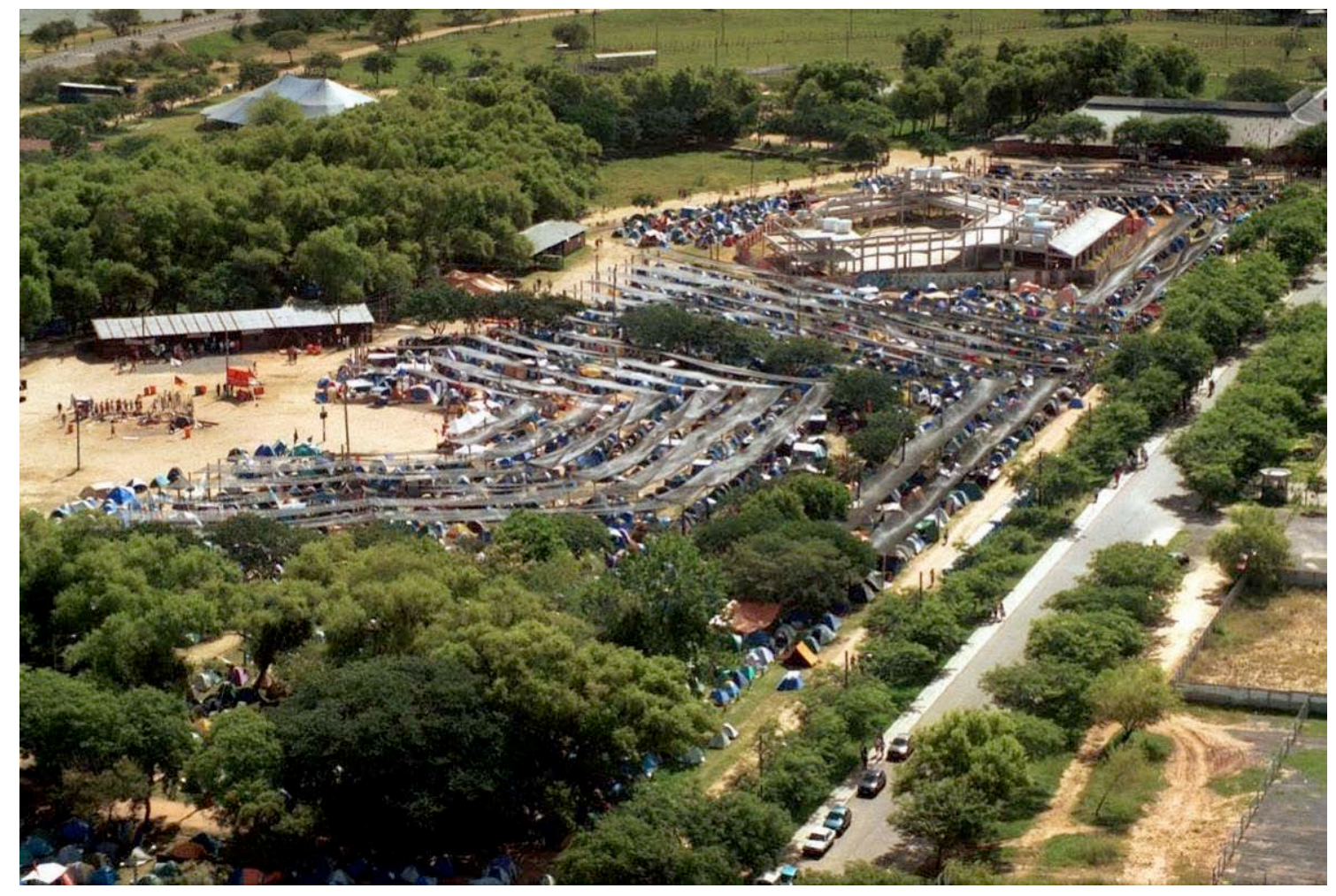

Figura 2.3

Acampamento Intercontinental da Juventude - Cidade Carlo Giuliani, 2002.

Fotografia: Leandro Anton.

Essa interpelação é vista como importante para o amadurecimento do "espírito de Porto Alegre" e o Comitê Organizador Brasileiro, referendado pelo Conselho Internacional, decide 
responder de forma concreta: entende-se que o evento deve buscar realizar o espaço político aberto que a Carta de Princípios anuncia, estendendo-se no espaço urbano e abrindo-se para a cidade. Na perspectiva de Gina Vargas, “os conhecidos desequilíbrios do Fórum são também matéria-prima para as mais ousadas propostas" (Vargas, 2009, p. 189). Descentralizar as atividades foi uma decisão custosa, que demandou da organização um esforço adicional de captação de recursos e gerou maior dependência das relações com agências de cooperação internacional, uma vez que o sólido apoio do Estado do Rio Grande do Sul à infraestrutura do evento estava, em grande medida, vinculado a um convênio com o Centro de Eventos da PUCRS. Até então, os gastos tinham sido mais previsíveis e menores do que o que demandava a construção de estruturas temporárias e a locação de equipamentos dispersos pela cidade. Considerou-se que era necessário assumir os riscos e parte da necessidade financeira foi coberta com apoio maior de empresas estatais, possibilidade que se abria já no contexto da vitória de Luiz Inácio Lula da Silva - que participara do Fórum em 2001 e 2002 - na eleição para a presidência da República. Enormes tendas brancas de lona são erguidas próximas ao parque Harmonia e, graças à locação de palcos, cadeiras e poderosa parafernália acústica, o auditório da Usina do Gasômetro e alguns dos armazéns do Cais do Porto são incluídos no evento.

Diante da série de impasses e questionamentos que emergiram nas duas primeiras edições, ainda segundo Vargas, "a característica mais marcante do FSM 3, em relação às anteriores, foi sua auto-reflexão" (2009, p. 189). Embora pouca ou nenhuma insatisfação com as estruturas organizativas transpareça nos documentos do Conselho Internacional, paralelas às críticas da concentração espacial, as novidades do FSM 2003 também buscavam responder ao acúmulo de questionamentos a respeito da própria estrutura decisória do processo-Fórum. Já em 2001, Naomi Klein, afirmara categoricamente que "a estrutura organizacional do fórum foi tão opaca que era quase impossível imaginar como as decisões eram tomadas ou encontrar formas de questionar essas decisões" (Klein, 2001). Não se tratava de uma crítica isolada. Após o evento de 2003, Peter Waterman vê na implantação da nova disposição espacial a mesma falta de transparência e representatividade do CI e do Comitê Organizador, sugerindo que o espaço aberto do Fórum não esteja tão distante assim da "velha política" de partidos e parlamentos quanto se quer anunciar (Waterman, 2008, p. 110). 
O Fórum de Porto Alegre é uma ágora onde há algumas grandes tendas de circo grandes, bem posicionadas e bem publicizadas, cercadas por uma miríade de outras de tamanhos diferentes (hoje cerca de 1.700 no total - o que significa 300 a 400 eventos por dia), propostas por movimentos sociais, agências internacionais, organizações políticas, instituições acadêmicas e até indivíduos. Os eventos Suburbanos/Periféricos competem por visibilidade, por locais, por tradutores/equipamento e frequentemente se sobrepõem ou reproduzem uns aos outros, e - ainda que certamente contribuam com o pluralismo do Fórum - têm impacto inevitavelmente menor. Mais uma vez, não obstante a decisão de que o Fórum não é um corpo formador de políticas permita pluralismo e criatividade, o resultado é inevitavelmente, a dominação pelo programa oficial - que foi concebido sem discussão notável para além dos comitês governantes (Waterman, 2008, p. 110).

As tendas de circo a que Waterman se refere são as grandes estruturas temporárias armadas para abrigar atividades da programação do FSM 2003. A imagem abaixo ilustra a disposição dessas estruturas no espaço. No desenho, feito por integrantes do Comitê do Acampamento da Juventude, vemos as instalações criadas para acomodar alguns eixos de atividade na região da Orla do Rio Guaíba, ao lado do Acampamento.

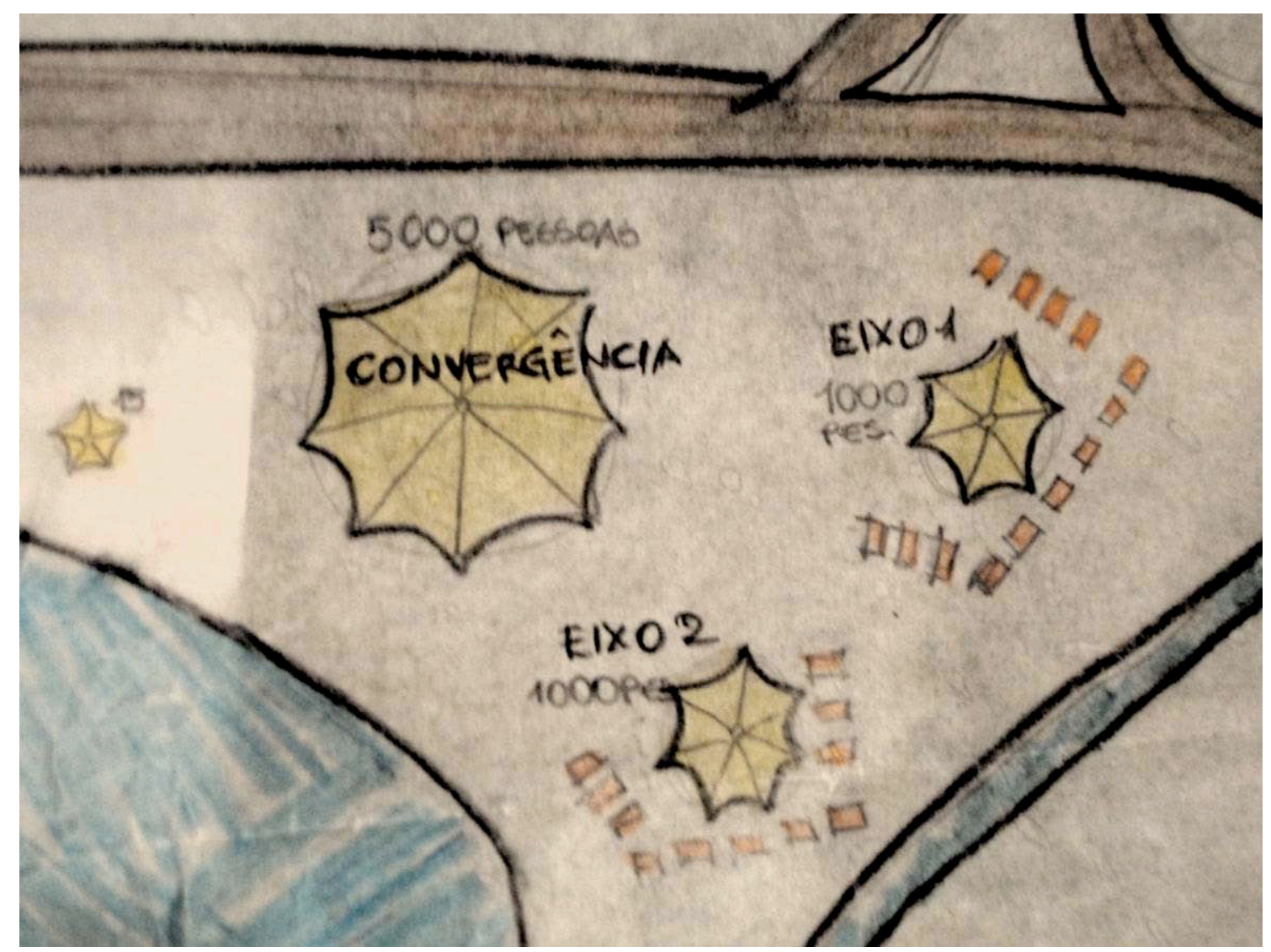

Figura 2.4

Detalhe de mapa de planejamento do Território Social Mundial - FSM 2005 (2004): localização e capacidade de tendas (“de circo") à margem do Rio Guaíba. Fonte: CasaTierra, fotografia da autora. 
Como sugere o comentário de Waterman, apesar do grande esforço em promover um movimento de horizontalização pela distribuição de atividades pela cidade, o novo desenho também termina por trazer a céu aberto relações centro/periferia implícitas na programação do Fórum que talvez fossem menos visíveis no espaço racionalizado e homogêneo dos corredores da PUCRS. A crítica de Waterman refere-se, assim, não ao princípio abstrato do espaço político aberto, mas aos claros impasses produzidos na medida em que o Fórum se torna definitivamente um megaevento, e que as contradições de sua realização no tempo e no espaço urbano tomam também proporções maiores.

Iniciativas de seminários, conferências e encontros, cujo número crescera espantosamente após as duas primeiras edições do Fórum, competem pelos "melhores" espaços de atividade, disputados por sua capacidade de público, equipamentos disponíveis, por sua localização na cidade e por outros critérios de acessibilidade e visibilidade, variáveis segundo interesses e afinidades particulares. Proporcionalmente ao número de páginas do caderno de programação - "quase tão grosso quanto o jornal de domingo", segundo Tadzio Mueller (2005) -, crescem as montanhas de panfletos e cartazes de divulgação das atividades programadas que as entidades participantes deixam para trás após o evento, a cargo do serviço público de limpeza da cidade.

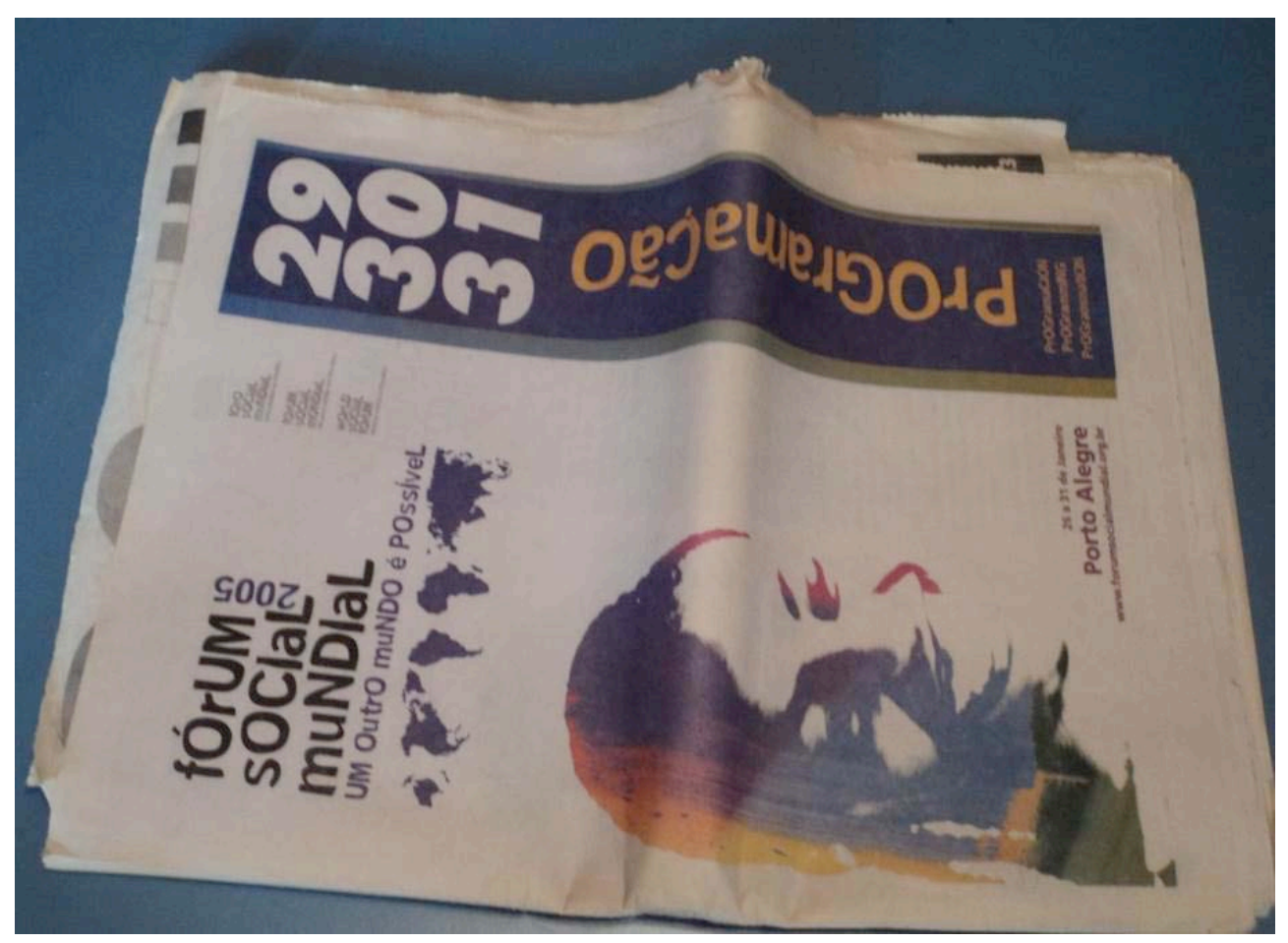

Figura 2.5

Um dos quatro volumes do caderno de programação do Fórum Social Mundial de 2005

(2012). Fonte: CasaTierra 
Essas tensões identificadas por alguns analistas como típicas de uma "febre de crescimento", certamente não passavam despercebidas aos participantes, por sua vez responsáveis pelo sucesso ou fracasso das iniciativas de suas respectivas organizações no marco da programação geral. Quando o Fórum, já em 2002, atinge cinquenta mil participantes, ainda que a euforia dos encontros e o engajamento genuíno nos processos que ali convergiam pudessem minimizar todos os desconfortos, a concorrência por recursos, projeção e público produz conflitos, além de desgaste físico e desânimo.

Inseparáveis dos desgastes afetivos e materiais, as críticas à falta de clareza nos critérios de hierarquização das atividades, à dispersão, à repetição, à falta de comunicação entre iniciativas e à ausência de registros ou estruturas de comunicação entre as atividades propostas pelos participantes também passam a ser mais claramente incorporadas pela organização na preparação para o Fórum de 2003. Ao mesmo tempo, há pressão das entidades participantes pela inclusão de suas fórmulações específicas de temas de trabalho como eixos "oficiais" do Fórum Social Mundial.

Essas pressões parecem fortalecer o entendimento de que uma arquitetura das atividades realizadas pelos organizadores do Fórum devia prever e dar conta de uma multiplicidade crescente de demandas, em particular aquelas oriundas das próprias redes, coalizões e organizações integrantes do CI (que também passa lentamente por um processo de expansão). No âmbito do CI, durante a preparação do FSM 2003 e após sua realização, o interesse no desenho metodológico cresce, intensificam-se consultas informais e debates internos à Comissão de Metodologia e ao Comitê Organizador Brasileiro em torno desse desenho.

Assim, a metodologia se consolida como o terreno de negociação e solução de conflitos, em que são debatidas e incorporadas demandas e pressões dos participantes. A incorporação progressiva de demandas converte-se, inicialmente, em um aumento da variedade de tipos de atividades propostas pelas instâncias organizativas do Fórum. Em 2003, por exemplo, além das conferências, painéis e testemunhos, aparecem as mesas de diálogo e controvérsia, dedicadas a explicitar divergências de posição existentes entre os membros do Conselho Internacional e particularmente a criar um canal de debate (aproximação ou confronto) nas destes com partidos, governos e com a esfera das Conferências da ONU. Ao mesmo tempo, os eixos temáticos se multiplicam e se desdobram em sub-eixos, cujas atividades maiores também permaneciam sob a responsabilidade financeira e organizativa do Comitê Organizador e do Conselho Internacional.

Ao mesmo tempo, procura-se expandir o campo para a visibilidade das oficinas, seminários e conferências não determinados pelo Comitê Organizador Brasileiro e pelo Conselho Internacional, que deixam de ser apenas oficinas e ganham em 2003, o nome abrangente de atividades autogestionadas, passando a concorrer também pelos espaços de maior público, antes reservados 
apenas às iniciativas de responsabilidade do núcleo organizador. O conceito de atividades autogestionadas busca enfatizar a autonomia das organizações participantes na proposição e produção de atividades e ao mesmo tempo, marcar a separação dessas iniciativas com relação à voz "oficial” do Fórum. O FSM ofereceria espaço, mas não responderia pelos conteúdos autogestionados: os convidados, as mensagens e ações expressas em cada atividade dizem respeito a seus organizadores e proponentes particulares. Assim, a metodologia não se propõe a ser um instrumento de coordenação da expressão coletiva do Fórum, mas uma ferramenta que garanta a manutenção de diferenças. Contida já nas definições de funcionamento do Conselho Internacional, a ideia forte na ampliação da presença das atividades autogestionadas no programa é a de reforçar "o caráter de espaço aberto que respeita a diversidade e a pluralidade" como atributo de uma metodologia do FSM, "sua principal força” (Regras de Funcionamento do CI, 2003) .

Em 2003, no núcleo de atividades propostas através das instâncias de coordenação, foram realizadas no total 10 conferências, 22 testemunhos, 4 mesas de diálogo e controvérsia e 36 painéis. Sozinho, esse núcleo de atividades reuniu um total de 392 conferencistas de diversos países, número mais que três vezes superior ao de 2001, que trouxe um total de 104 conferencistas representantes de redes, organizações e movimentos sociais do mundo inteiro. No conjunto de atividades autogestionadas, houve um salto de cerca de 400 no FSM 2001 para cerca de 1.300 em 2003 (Histórico do Processo FSM, 2007). O celebrado crescimento ocorrido entre 2001 e 2003 reflete a crescente afluência de público, mas também a deliberada multiplicação dos postos de visibilidade durante o evento FSM. A forma mais simples alcançar visibilidade segue sendo uma "vaga", com direito a fala, em uma atividade bem localizada e bem publicizada, divulgada com destaque no programa oficial e pautada na rede de imprensa alternativa, seja a convite do comitê organizador, seja a convite de uma entidade participante no formato autogestionado (em que cada organização promove a visibilidade de sua atividade e distribui falas por conta própria).

A visibilidade das "autogestionadas" depende dos recursos financeiros e políticos da própria organização ou, de preferência, da articulação de um agrupamento de organizações proponentes. Quanto à complexa tarefa de sua alocação nos espaços disponíveis - que sempre incluiu critérios diversos de "peso" político das organizações proponentes e sempre esteve a cargo do trabalho do comitê organizador e de sua secretaria - começa-se a explicitar que há prioridades reservadas às iniciativas conjuntas entre entidades. Ganham especial atenção e salas maiores as representatividades (sempre relativas) associadas ao poder de mobilizar pessoas e/ou de captar recursos, algo que as entidades conseguem produzir ou ampliar consideravelmente associando-se umas às outras para propor iniciativas comuns. Crescentemente incorporada pela metodologia, essa dinâmica de associação entre organizações e movimentos para promover atividades no âmbito do 
FSM é chamada de "convergência" e entendida como princípio e função primordial do Fórum: espaço capaz de promover agrupamentos entre os que, preservadas as diferenças, almejam um outro mundo possível.

Em 2004, quando o Fórum é realizado na Índia, a metodologia é considerada fundamental na garantia de continuidade entre eventos realizados em condições geográficas, sociais, culturais, econômicas e políticas inteiramente diferentes. Duas salvaguardas foram admitidas pelo Conselho Internacional como condição para que o evento se realizasse em Mumbai. Em primeiro lugar, fora acordado, ainda em 2003, que o Fórum voltaria a Porto Alegre em 2005. Em segundo lugar, o Comitê Organizador Brasileiro e sua secretaria sediada no Brasil são promovidos a Secretariado Executivo do Conselho Internacional, o que confere mobilidade às organizações brasileiras para participar ativamente do processo preparatório na Índia - em particular no acompanhamento das continuidades metodológicas identificadas ao Espírito de Porto Alegre. Isso não impediu, no entanto, que o Fórum de Mumbai seguisse caminhos diferentes dos já experimentados no Brasil. Os organizadores indianos recusaram o financiamento da Ford Foundation (importante apoiadora do evento de 2003 em Porto Alegre ${ }^{31}$ ) por suas relações com os interesses corporativos e militares estadunidenses; mandaram construir com técnicas locais estruturas baratas para abrigar as atividades, em vez de contratar um centro de eventos; usaram software livre sem reservas (Nunes, 2005) e passaram as grandes conferências, debates e testemunhos para o formato autogestionado.

É no FSM de Mumbai que, pela primeira vez, os documentos públicos de metodologia apresentam os critérios de alocação das atividades: "se houver conflitos de espaço... a seleção será feita sob os critérios abaixo: a. Diversidade dos grupos proponentes (de uma atividade); b. Equilíbrio entre os vários tópicos; c. Perspectiva global (abrangência política e geográfica do tópico)" ("Metodologia do FSM 2004", 2003). Os critérios favorecem claramente as atividades produzidas em conjunto por diferentes entidades, buscando incentivar o agrupamento de propostas para combater a dispersão e a repetição de iniciativas. Ao mesmo tempo, a ideia geral é que quanto menos os recursos de visibilidade (espaço, equipamentos, divulgação, etc.) sejam restritos às iniciativas de um Comitê Organizador, mais visível será a diversidade de formas e posições políticas que circulam no Fórum.

Segundo o documento "Metodologia do FSM 2004" (2003), esse novo formato geral deve "mostrar claramente quão abrangentes e inclusivas são nossas preocupações de dedicação para tornar outro mundo possível". Quanto mais os espaços “centrais” puderem ser ocupados através de iniciativas de convergência voluntária entre entidades participantes, ao invés de serem distribuídos

\footnotetext{
${ }^{31}$ Ver lista de apoiadores do FSM no Anexo C.
} 
segundo critérios de um grupo "dirigente", mais próximos estaríamos de uma "nova forma de fazer política" e mais visíveis se tornariam as mensagens políticas a serem transmitidas para além dos limites do Fórum.

Ainda neste documento sobre a metodologia em Mumbai, há uma explicitação da natureza dos eixos temáticos, que passam agora a chamar-se "áreas": a proposta é que as áreas temáticas sejam uma estrutura de referência descritiva e informativa - "continuando a encorajar os participantes a sentirem-se à vontade para propor suas atividades" (FSM Comissão de Metodologia, 2003). Além das áreas temáticas, a metodologia propunha, pela primeira vez, "eixos de transversais" 32 , indicativos de campos de embate político a serem mantidos em foco nos debates, a partir das perspectivas de todas as diferentes áreas temáticas. Estes eixos - ditos também eixos “de luta" - reiteram a preocupação, aportada em grande medida pelos organizadores indianos, de que as áreas temáticas e suas muitas subáreas ${ }^{33}$ fossem organizadas de modo a possibilitar proposições estratégicas a serem incorporadas pelos "atores/agentes globais da sociedade civil", relativas a "processos de organização e luta em andamento". Na prática, em Mumbai, grandes conferências proferidas por notáveis internacionais ficaram muitas vezes esvaziadas, enquanto oficinas promovidas por grupos locais e regionais reuniam pequenas multidões.

A metodologia proposta para a última edição do FSM realizada em Porto Alegre, em 2005, tratou de reinterpretar as mudanças marcantes que o desenho do Fórum recebera em sua passagem pela Índia. Permanecia a intenção de "evitar a repetição desarticulada dos debates, favorecer a construção de ações e campanhas comuns" e, ao mesmo tempo, "deixar intacto o princípio de autonomia e de rejeição ao dirigismo" (FSM Comissão de Metodologia, 2004). Os eixos, ou polos temáticos, agora eram onze, formulados com apoio de uma consulta prévia às entidades participantes através da internet e seguida de um trabalho interpretação, classificação e síntese no âmbito do CI, em particular da Comissão de Metodologia, responsável pelo temário. Participaram voluntariamente da consulta 1.863 entidades, propondo através de um formulário on-line, os temas que gostariam fossem debatidos no FSM 2005. O conteúdo dessas propostas foi processado pela Comissão de Metodologia e pelo Comitê Organizador até que se encontrasse uma redação definitiva, que pudesse dar conta de certa diversidade compreendida dentro dos critérios da Carta de Princípios, particularmente estrita quanto ao caráter não confessional, não governamental e não

\footnotetext{
${ }^{32}$ Cinco deles: Globalização imperialista; Patriarcado; Regimes de castas e racismo e exclusões sociais; Sectarismo religioso, políticas de identidade e fundamentalismo (comunalismo) e Militarismo e paz (FSM Comissão de Metodologia, 2003).

${ }^{33}$ Para o Fórum de Mumbai foram formuladas, através do processo de consulta aberta à entidades participantes, de cinco a quinze subáreas para cada eixo, a serem indicadas no momento da inscrição das iniciativas pelas entidades. A lista completa está disponível em http://www.forumsocialmundial.org.br/dinamic.php pagina=anexo1_metodo_2004_p. Publicado em 13 de outubro de 2003, acesso em 6 de novembro de 2011.
} 
partidário do encontro. O número de temas não foi fixado a priori; o exercício foi identificar elementos comuns às diferentes propostas e deles derivar as linhas gerais do conteúdo do Fórum. $\mathrm{O}$ novo processo de definição temática foi celebrado como um avanço na ampliação da participação das entidades nas tomadas de decisão. Mais uma vez, a metodologia é o âmbito em que se busca combater uma fragilidade política do Fórum, em particular os desconfortos e acusações de centralização e falta de transparência dos processos decisórios.

Além da definição dos temas específicos, que agrupavam iniciativas segundo assuntos, foram incorporados à metodologia 2004/2005 cinco eixos transversais' diferentes porém, daqueles formulados para Mumbai ${ }^{34}$. Menos dirigidos à enunciar frentes de ação comuns, apesar de mantidos alguns termos, os eixos transversais propõem um sentido mais claramente metodológico para diferentes dimensões dos debates a serem realizados pelas entidades participantes. O primeiro, "Emancipação social e dimensão política das lutas", parece uma indicação algo acadêmica sobre o horizonte emancipatório e as disputas de poder implicadas no debate sobre transformação social, que aos organizadores parecia importante tornar presentes. O segundo e o terceiro - "Luta contra o capitalismo patriarcal" e "Lutas contra o racismo e outras formas de exclusão baseadas na ascendência" recolocam, na forma de tópicos de debate, o sentido estratégico dos eixos transversais de 2004. Em resposta às críticas, originárias do próprio CI, à predominância de homens brancos e intelectuais nas posições de visibilidade criadas pelo FSM, os dois últimos eixos transversais de 2005 - gênero e diversidade - são claramente orientações de conteúdo, indicando também critérios de equidade para a composição de mesas e listas de palestrantes. Sobre a referência ao racismo a ser combatido, os eixos transversais são concebidos como estímulos à distribuição de visibilidades, agora prioritariamente definida de forma descentralizada e autônoma pelas entidades proponentes. A “cultura", que desde 2001 fora um segmento separado da programação de debates, conferências e oficinas, é agora percebida como fator fundamental na "interação do Fórum com a cidade" e incorporada, tornando-se também um "eixo transversal”, mesmo porque a população de Porto Alegre parecia frequentar mais as apresentações artísticas em geral do que as salas de conferência.

No Fórum Social Mundial de 2005, todas as iniciativas passam a ser autogestionadas. Uma vez concluída a fase de consulta temática e a definição de eixos, dá-se início às inscrições das atividades. O princípio de convergência desdobra-se agora em um complexo processo de associação

\footnotetext{
${ }^{34}$ Eixos transversais do FSM 2005:

- Emancipação social e dimensão política das lutas

- Luta contra o capitalismo patriarcal

- Lutas contra o racismo e outras formas de exclusão baseadas na ascendência

- Gênero

- Diversidade
}

FSM 2005 "Lista de temas da edições do FSM (2001 a 2006)", publicado em 20 de outubro de 2005 em http://www.forumsocialmundial.org.br/dinamic.php?pagina=temas_fsm_por 
voluntária, pelo qual iniciativas com temas e perspectivas consideradas afins são estimuladas a fundir-se umas às outras. Para cada área temática, os membros do Conselho Internacional propõem a formação de grupos aglutinadores, responsáveis por identificar afinidades entre iniciativas inscritas, indicar e incentivar possibilidades de fusão. As negociações para a convergência de atividades, chamadas agora de processo de aglutinação, contam com intensa facilitação - termo dos documentos de metodologia que quer indicar uma forma de coordenação sem dirigismo - destes grupos e da Comissão de Metodologia do CI.

Partindo do princípio de que as entidades participantes estão cientes da necessidade de somar esforços na construção de ações comuns, define-se como tarefa da metodologia a criação de condições para que os participantes possam realizar atividades conjuntas. Por exemplo: "uma organização da Costa Rica que enfrenta a privatização das fontes de água [...] terá todo interesse em se somar a entidades que enfrentam o mesmo problema na Tailândia, em Moçambique ou na Itália" (FSM Comissão de Metodologia, 2004). Ao mesmo tempo em que a responsabilidade de proposição das atividades que compõem a programação passa às entidades - tudo agora pode ser autogestionado - a sinergia entre essas iniciativas passa a ser tratada (ao menos formalmente) como efeito de sua adesão à metodologia da aglutinação. É importante notar que a autogestão e a aglutinação são sempre categorias vinculadas à inscrição e aos temas formulados a partir das consultas via Internet, mecanismos geridos como tarefas operacionais pelo escritório, sob coordenação do Comitê Organizador Brasileiro, a partir das definições da Comissão de Metodologia. Quaisquer iniciativas independentes destes processos são consideradas "paralelas" ao Fórum Social Mundial.

"Devemos assumir o compromisso de promover uma revolução no sistema de inscrição do próximo Fórum", dizia o documento preparatório para 2005: “Ao registrar sua atividade, via Internet, cada organização precisa ser instantaneamente informada sobre as iniciativas semelhantes já propostas e ter acesso ao nome, endereço eletrônico e telefone de seus produtores" (idem). A revolução passa assim, pela complexificação trabalhosa do sistema de banco de dados mantido pela secretaria do FSM, que delega as iniciativas às organizações participantes ao mesmo tempo em que atualiza a centralização do processo de inscrições. A nova metodologia, introduzindo a noção de aglutinação, busca também englobar as relações entre as entidades participantes, projetando-se sobre o universo de tratativas, trocas e alianças que está na base da iniciativas de atividades e que era, até então, percebido como problema de caráter "autogestionado".

Essas transformações marcam uma nova abrangência da metodologia em todos os níveis: sua consolidação como uma ciência dos usos do espaço aberto e sua conversão última em arquitetura. Se originalmente os eixos temáticos eram orientações didáticas sobre o que poderia se 
feito e debatido no âmbito do Fórum, em 2005 eles definem espaços temáticos físicos na cidade de Porto Alegre. Mais do que expressar semelhanças preexistentes entre as entidades participantes, a serem trazidas à tona nos discursos, o novo método chega agora a definir uma divisão territorial associada a afinidades temáticas, a perspectivas ou a áreas de atuação particulares. Uma vez estabelecidas onze áreas pela comissão de metodologia, cada entidade pode associar suas iniciativas aos temas de sua eleição, mas a inscrição temática possui agora implicações diretas para os percursos que pessoas e discursos realizam durante o evento do Fórum. Na mesma medida em que as relações estabelecidas entre entidades se inscrevem na metodologia sob a forma das aglutinações ou convergências, a própria metodologia se inscreve no espaço urbano pela criação de um Território Social Mundial.

Para isso, foi identificada e demarcada, com auxílio da prefeitura e de uma equipe de urbanistas, uma grande área contínua da cidade destinada a acolher as atividades do Fórum e demonstrar a vivacidade e a diversidade de concepções e práticas de seus integrantes. Os debates internos no Conselho Internacional identificaram a necessidade de que, em vez de inscrever-se no desenho preexistente de um centro de eventos, o processo criasse seu território próprio e "popular", de modo a expressar espacialmente a política de horizontalidade que o método FSM supostamente inventava no plano organizativo.

O debate desenvolvido sob o olhar das três edições de Porto Alegre e da recente edição do FSM na Índia trouxe o amadurecimento de necessidades, transformandoas em desafios ao FSM2005, o principal deles, a ampliação da popularização. Esse caráter popular se traduz numa maior integração na dinâmica local, buscando vínculo com elementos simbólicos da cidade, marcando um novo território para a "cidade FSM" (FSM 2005 - Grupo de Trabalho Espaços, 2004).

Tornar o Fórum “mais popular", como na edição de 2003, tinha a ver então com recusar a concentração das atividades na PUCRS, instituição identificada à elite porto-alegrense. Um Grupo de Trabalho, integrado por uma equipe contratada de arquitetos responsável por estudos de viabilidade, projetos e obras de implantação das estruturas do evento, é então encarregado do planejamento. $\mathrm{O}$ espírito era levar as atividades até a população, realizando-as no espaço público para que fosse estabelecida uma dinâmica simbólica própria, conferindo ao conjunto do fórum o caráter de uma experiência integral de "outro mundo" - algo certamente inspirado pelo invejável magnetismo produzido pelo Acampamento da Juventude nos anos anteriores (Nunes, 2005).

A não ser pelas marchas de abertura e encerramento ou pela programação de shows musicais públicos que desde 2001 acompanharam o programa de atividades, as primeiras edições do Fórum se concentram em espaços fechados onde a principal atividade são a falas, debates ou palestras, não 
necessariamente convidativos e possivelmente pouco visíveis para pessoas que não tenham nenhuma relação prévia com os circuitos militantes da cidade. Já o Acampamento da Juventude, localizado no Parque Harmonia, impulsionado por um comitê independente da organização do FSM, com apoio da Prefeitura e do Estado, é concebido desde 2002 como uma cidade dentro da cidade, mantendo intenso trânsito com a vida urbana e com outros usos do espaço público em Porto Alegre (Nunes, 2005, p. 284).

Enquanto o Fórum se consolidara como é um evento em que uns apresentam ideias e outros assistem, onde as atividades via de regra são intelectuais, o Parque Harmonia na região central ocupado por milhares de barracas, estruturas simples feitas de barro, madeira e sucata, laboratórios de mídia rodando a base de softwares livres e pequenas redes autônomas de comunicação, artistas de rua, vendedores de artesanato, chuveiros coletivos, camisetas com mensagens revolucionárias e comida caseira - é um espaço em que em que a participação se dá de formas múltiplas, onde se estimula que não apenas as "entidades” mas também indivíduos tomem parte da complexa vida política de uma "cidade" temporária. Além de assistir e contribuir em oficinas, assembleias e debates, os participantes são estimulados pelos organizadores do acampamento, desde sua chegada, a assumir responsabilidades pelo bem-estar coletivo e auto-organizar-se para cumprir tarefas comuns como limpeza e segurança

Embora as mudanças implementadas no evento realizado em 2005 tenham sido amplamente descritas nos documentos como frutos das "lições de Mumbai", propostas importantes da metodologia apropriavam termos e soluções formais criadas no Acampamento ainda em 2002. São estes: a forma autogestionada e autofinanciada como condição de todas as atividades; o uso de técnicas artesanais na montagem das instalações; o emprego de sistemas de software livre; e uma relação com o "mundo exterior" ao fórum focada não nos grandes veículos e empresas, mas em redes pequenas, autônomas e populares de comunicação, serviços e abastecimento (Nunes, 2005). ${ }^{35}$

Vale destacar que a metodologia é vista com desconfiança pelo grupo local de organizadores do Acampamento, cujo Comitê é formado por militantes do movimento estudantil, dos núcleos de base do PT gaúcho e outros partidos de esquerda, do Movimento Nacional de Meninos e Meninas de Rua, do crescente movimento hip-hop de Porto Alegre e muitos indivíduos e membros de coletivos pequenos (Idem). Mesmo com a participação de seus representantes reconhecida nas instâncias organizativas locais e nacionais do Fórum, o Comitê do Acampamento trata de manter,

\footnotetext{
${ }^{35}$ Sobre a história do Acampamento da Juventude e dessa "mímese", o artigo de Rodrigo Nunes, "The IYC as the unthought of the WSF", publicado na revista Ephemera $N^{\circ} 5$, em 2005, traz uma série de informações e reflexões importantes. Ainda que muitas noções fortes, gestadas no Parque Harmonia, tenham sido incorporadas à metodologia em 2005, o AIJ permaneceu à margem das tomadas de decisão e de uma história do processo FSM construída do ponto de vista de organizações pouco ou nada envolvidas nessa experiência.
} 
até 2005, um sistema independente de inscrições, não condicionada ao vínculo dos indivíduos a entidades. Até 2005 também, o AIJ conta com uma programação paralela, elaborada por fora do sistema do evento, cuja organização passa por uma forte rejeição da separação entre causas prioritárias e secundárias, defendendo de forma obstinada a permanente mistura entre atividades e debates "políticos”, expressão artística, tecnologias, comunicação e tarefas cotidianas de produção de um espaço de convívio.

Não por acaso, em seu projeto de "popularização" do evento, os organizadores decidem instalar a atividade do FSM em um Território Social Mundial na mesma região central e de fácil acesso em que crescera o Acampamento. Anunciado como uma nova cidade dentro da cidade, esse Território busca englobar, simbólica e espacialmente, o Acampamento, trazendo para seu centro as imagens de um encontro aberto e jovem, baseado, não em projetos abstratos, mas em práticas inovadoras. "Que os participantes do FSM não apenas usufruam do evento, mas que vivenciem sua construção numa prática e compromisso radical de mudança", afirmou-se no evento de lançamento do FSM 2005. Vemos na figura a seguir uma espécie de mapa político deste território, em que "temas" e "práticas" se encontram. 


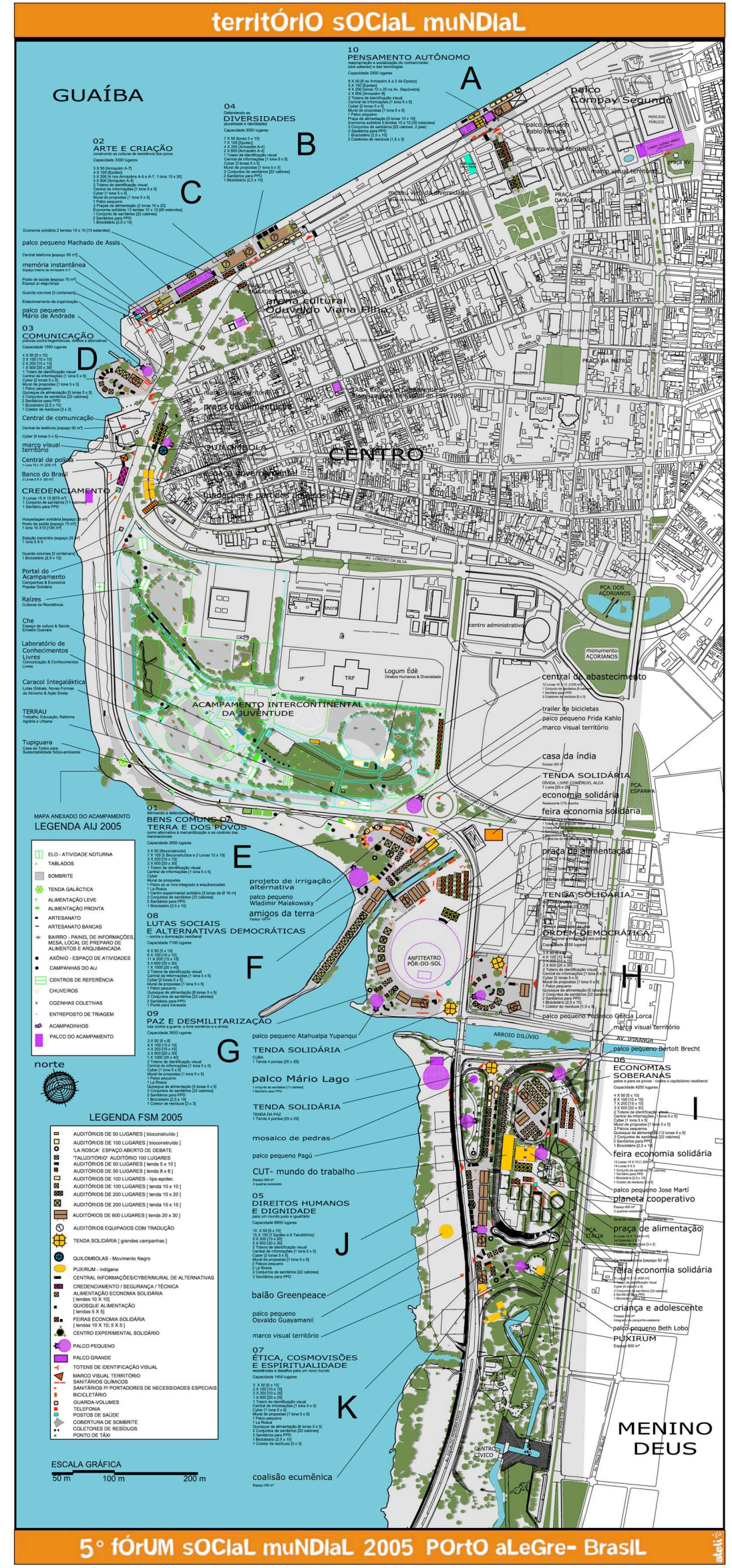

Figura 2.6 
O traçado projeta no espaço as definições tiradas de um processo de consulta temática e de aglutinação: cada tema ocupa um terreno e ganha estruturas especificamente planejadas e construídas para a ocasião. Como vemos no mapa (figura 2.6, acima), cada um dos 11 eixos foi transposto em territórios dedicados à realização de atividades em torno de um mesmo tema, instalados ao longo da margem do Rio Guaíba. Além de tendas e auditórios temporários para encontros e conferências, cada secção do território recebeu praças de alimentação, centros de apoio, postos de saúde, estandes das organizações, comercialização de produtos de redes de economia solidária e patrocinadores. Como um "eixo transversal”, a programação cultural é também distribuída espacialmente, sendo instalados palcos em todos os espaços temáticos e fomentada a circulação de obras "de rua", como performances e peças de teatro que "dialogassem" com o território. Nesse contexto é criado um escritório em Porto Alegre, cujo trabalho compreende a supervisão dos projetos, a execução das obras, a relação com as organizações de fornecedores, prestadores de serviços e movimentos sociais locais que colaboram com a empreitada, além de diferentes instituições que apoiam a infraestrutura, incluindo a Prefeitura de Porto Alegre, o Governo do Estado do Rio Grande do Sul e o Governo Federal. Além das fundações e agências de cooperação envolvidas nas edições anteriores, o FSM 2005 contou também com o apoio de mais empresas estatais $^{36}$ (ver Anexo C: tabela de apoiadores do evento FSM em 2003 e 2005).

No projeto urbanístico do território temporário, a proposta é que as obras deixem na cidade estruturas de uso público: o trecho ao longo da orla, que vai da Usina do Gasômetro ao ginásio Gigantinho ganham assim reforços na rede elétrica e infraestrutura de Internet, na rede de água, esgoto e drenagem.

Durante 40 dias, cerca de 1.900 trabalhadores ergueram as construções dos espaços, obras orçadas em R $\$ 4,4$ milhões. Ao todo, são 150 mil metros de área construída, um espaço equivalente à área de 18 estádios de futebol do tamanho do Maracanã. O coordenador executivo do escritório do FSM 2005 em Porto Alegre [...] comentou: "É uma cidade que nasce dentro de outra cidade, com uma vida própria e várias propostas de construção" (Weissheimmer, 2005).

Com a redução significativa do apoio do Governo do Estado na infraestrutura, trata-se da primeira vez que a organização do FSM assume integralmente a coordenação logística da realização de um evento para centenas de milhares de pessoas. A diversidade dos apoios garante uma arrecadação 50\% maior do que fora alcançado em 2003. No entanto, isso não impede que o Fórum

\footnotetext{
${ }^{36}$ Vale lembrar que, em um evento em que as atividades são definidas como autogestionadas, a captação de recursos é descentralizada, o que torna seu mapeamento difícil. Aqui, é possível apenas elencar os apoiadores do FSM em si mesmo, através dos escritórios de organização e das entidades do comitê organizador, para oferecer um contexto geral de relações extremamente importantes, mas cujo mapeamento minucioso foge ao escopo deste trabalho.
} 
de 2005 se encerre com mais de um 1,5 milhão de dólares em dívidas com prestadores de serviços e empréstimos de ONGs engajadas no processo (Carta da Comissão de Recursos, 2005).

Nesse esforço sem precedentes, o FSM se descola finalmente do Centro de Eventos da PUC e se instala em uma área de 4,5km de extensão (somadas todas as áreas temáticas), onde cerca 6.872 organizações de 151 países encontram-se envolvidas em não menos que 2.500 atividades registradas na programação e quem sabe quantas mais não registradas. É a primeira vez que a metodologia do Fórum explicita sua relação com o espaço da cidade que recebe o evento, considerando a circulação dos participantes como parte de seu desenho conceitual, processo que os documentos da Comissão de Espaços definem como uma "nova dinâmica de territorialização".

Dessa forma, a nova metodologia inscreve as circulações políticas no espaço, traçando caminhos concretos no Território Social Mundial. Se fosse possível desenhar no mapa daquele território, com cores diferentes, as caminhadas entre o Cais do Porto e o Parque Marinha realizadas pelos participantes durante os dias do Fórum 2005, quem saberia dizer quantas relações se tornariam visíveis? As afinidades e afastamentos entres os grupos tornam-se contiguidades palpáveis, assim como os isolamentos se fazem muito concretos; o trânsito de mais de seis mil jornalistas e o fluxo pulsante das tendas de conferência em torno dos convidados mais conhecidos e grande plenárias dão corpo ao jogo das visibilidades; caminhos mais discretos marcam as conexões entre os espaços menores, desenham-se as cirandas dos movimentos aliados, os encontros inevitáveis nas encruzilhadas: o Acampamento da Juventude, no meio deste novo território, é atravessado por milhares de linhas de tensão .

O espraiamento das atividades em um terreno novo, que torna visível a intensa circulação dos participantes entre os espaços, foi explorado em muitas análises e balanços como metáfora fundamental da integração dos diferentes eixos de debate. Somada à consulta temática e à generalização do formato autogestionado, a territorialização parece contribuir para uma imagem de maior horizontalidade de um Fórum crescentemente identificado ao seu método. Ao mesmo tempo, os números da última edição do Fórum realizada em Porto Alegre são monumentais. Segundo as estimativas da Brigada Militar, cerca de quinhentas mil pessoas circularam pelo Território Social Mundial nos dias de pico do evento, 29 e 30 de janeiro. O porte da infraestrutura e o volume assombroso da programação, coroada por conferências para quinze mil pessoas no estádio Gigantinho, com a participação dos presidentes Hugo Chavez e Lula, tensionam certamente a concepção de um espaço político sem dirigismos ou dirigentes.

A contrapartida é uma nova ênfase dada pelos organizadores à visibilidade da construção metodológica do Fórum: o caráter participativo da formulação dos temas através da consulta e a novidade da "aglutinação" ocupam muito espaço nos boletins mensais de divulgação e nas reuniões 
preparatórias do FSM 2005. Trata-se de um momento importante para a consolidação da ideia de que o Fórum é essencialmente um método de promoção de encontros e convergências. A metodologia definitivamente se explicita como uma arquitetura, um desenho estrutural que define disposições, cria categorias de relação e distribuição de espaços. O Fórum é apresentado em plena identificação a este traçado complexo, como uma forma separada das intenções e iniciativas de seus participantes, que oferece espaços a serem ocupados e não determina conteúdos ou direções.

\begin{abstract}
Aprofundou-se, assim, a opção [...] de abertura do seu espaço às atividades em torno das quais seus próprios participantes pretenderiam dialogar com outros e construir novas alianças. Esta característica tão fundamental ficou bem evidente pelo fato do programa do Fórum de 2005 não prever grandes conferências com grandes estrelas. Houve algumas mas elas foram organizadas pelos próprios participantes, como foi o caso por exemplo de Saramago - num debate que atraiu grande público - ou dos Presidentes Lula e Chaves. Nenhum deles veio a convite dos organizadores do Fórum. Eles tão somente atenderam a convites feitos por organizações dentro da regra da autogestão (Whitaker, 2005a).
\end{abstract}

Segundo essa proposição de que a lógica territorial experimentada em 2005 seria sua expressão mais avançada, o sentido político do Fórum Social Mundial estaria em sua natureza "metodológica", no exercício reflexivo implicado na formulação de regras de uso de um espaço aberto: uma praça que, idealmente, permanece inalterada, alheia às direções que venham a tomar as pessoas que nela transitam. É também na edição de 2005 que a definição do FSM como espaço passa a englobar o sentido de "práticas" que o Acampamento da Juventude há anos colocava em movimento. Não basta mais projetar no futuro um outro mundo possível, é preciso fazer ver este outro mundo aqui e agora, revelando o seu segredo. Em discursos como os de Boaventura de Souza Santos, o Fórum passa, definitivamente, a ser considerado em si mesmo uma prática capaz de revelação ou "tradução": ele é um método a partir do qual se inauguram relações novas (Santos, 2005).

\title{
Método e poder
}

Em vez de uma projeção de forças e capacidades na direção de objetos externos a serem conquistados, como poderíamos esperar de uma estratégia no sentido convencional, ao longo dos cinco primeiros anos em Porto Alegre e Mumbai, a ênfase no método significou um investimento crescente de energias e recursos no interior do próprio processo. No plano das instâncias organizativas - comitês organizadores e Conselho - os sentidos de eficácia e acúmulo passam também, e cada vez mais, a dizer respeito ao aprimoramento da capacidade de gestão de visibilidades e de consolidar de consensos, não sobre a melhor forma de combater o poder das 
corporações transnacionais ou as política neoliberais, mas sobre a própria eficácia do "método FSM".

Apesar de certo nível permanente de controvérsia, a interdição à tomada de posições políticas do FSM por si mesmo sobrevive como pedra fundamental do método. Mais de uma vez questionou-se sem maiores efeitos a ostensiva distância tomada pelas instâncias de representação do FSM com relação a qualquer ação ou pronunciamento. Por exemplo, quando, em uma reunião do CI, em janeiro de 2003, vários representantes de organizações e movimentos defenderam sem sucesso que o Fórum fizesse uma declaração pública contra a iminente invasão do Iraque por tropas estadunidenses e aliadas: apenas as entidades podem fazer declarações, que jamais devem ser confundidas com uma voz “do Fórum”. Não havendo posições a serem tomadas, e para evitar que isso aconteça, a maior parte das discussões do Conselho se mantem no registro da metodologia, cujo fundamento é a autonomia dos membros e a neutralidade do espaço comum. Outra crítica frequente, dirigida à predominância de homens brancos e com alta instrução formal nos postos de visibilidade gerados no Fórum, é rebatida por alguns organizadores nos mesmos termos: trata-se de uma falha das entidades participantes, livres em função da autogestão de suas atividades. Não se trataria de uma responsabilidade "do Fórum", ou do Comitê Organizador ou Conselho Internacional, já que estes são apenas espaços de facilitação e não efetivamente de "comando" ou liderança (Teivanen, 2009).

Como vimos no capítulo anterior, segundo uma lógica de "horizontalidade" e "abertura", diferente de um movimento, um espaço precisa apenas de pessoas e instituições prontas a realizar tarefas supostamente neutras para organizar seus usos respeitando a diversidade, sem interferir na liberdade dos participantes. Esta seria a condição para que o Fórum Social Mundial pudesse funcionar como uma "fábrica" de relações novas entre ideias e práticas, uma usina de convergência que operaria por um sistema horizontal de produção (Whitaker, 2009). Como indica April Biccum (2005, p. 126), a metáfora da produção, recorrente nas falas de alguns organizadores, não pode passar despercebida. A íntima relação entre as concepções do Fórum como método e como espaço, tem a gestão do trabalho como aspecto fundamental. Os produtores de posicionamentos e ações políticas são, por excelência, os participantes. A metodologia é a dimensão das regras de uso do espaço no interior do qual eles se veem reunidos, onde são postos em relação de modo a otimizar essa produção num sentido inteiramente novo. O Fórum seria assim uma forma organizativa inédita, idealmente neutra, que sem produzir hierarquias, reúne os meios e distribui os postos de visibilidade para o trabalho político almejado.

Essa analogia entre a forma do Fórum Social Mundial e as técnicas de gestão - típicas do terreno inimigo dominado pelo neoliberalismo - pode soar demasiado forte para quem espera ver na 
estrutura organizativa do FSM uma expressão de livre sinergia contrassistêmica, mas não é raro encontrá-la nos argumentos que buscam consolidar a ideia do Forum-espaço. Não temos nenhuma intenção de afirmar que sinergias conspiratórias e potencialidades subversivas estivessem ausentes das dinâmicas de encontro individuais e coletivas que o Fórum foi capaz de catalisar em seus cinco primeiros anos de existência. Mas parece difícil deixar de perceber que, se tomado do ponto de vista estritamente metodológico como esperam defini-lo muitos de seus organizadores e comentadores, o Fórum Social Mundial termina reduzido a uma estrutura de controles (parte real, parte fantasiosa), pouco horizontal e não muito diferente das práticas políticas já conhecidas há décadas por ONGs e movimentos sociais.

Para um observador atento às práticas e modos de fazer cotidianos que definem o funcionamento do FSM, é difícil encontrar aquilo que Boaventura de Souza Santos descreve como sendo sua novidade: "vista consensualmente em sua inclusividade e alcance global, na inexistência de líderes e organização hierárquica, em sua ênfase nas redes do Cyberspaço, em seu ideal de democracia participativa, em sua flexibilidade e avidez pela experimentação" (Santos, 2005a). A consideração da Carta de Princípios como base do método Fórum, obriga, de saída, o reconhecimento de que a constituição desse espaço político se dá com base em uma série de exclusões categóricas - por exemplo, a dos partidos políticos. A composição do Conselho Internacional do Fórum, responsável pelas definições metodológicas que descrevemos, e mesmo as pesquisas de participação realizadas em 2005 (Coradini, 2009), por sua vez, indicam que o alcance global do Fórum, menos do que ser invenção inteiramente nova e descolada de seu tempo, mimetiza as formas conhecidas de uma sociedade civil mundial já constituída em torno do sistema de cooperação internacional, cuja inclusividade cultural, geográfica e politica é sempre parcial.

Finalmente, o plano da metodologia, nos múltiplos sentidos e desdobramentos indicados ao longo do capítulo, revela os aspectos em que o FSM mais se distancia da aclamada forma horizontal e/ou sem líderes. Regras de uso do espaço implicam em relações de poder e, ainda que não haja hierarquias entre os diferentes usuários desse espaço regulamentado, certamente há hierarquia entre aqueles que definem as regras e aqueles de quem se espera obediência. A inviolabilidade da Carta de Princípios e a própria ideia de que o Fórum só pode proliferar e deslocar-se pelo mundo sob um mesmo "método" são diretrizes que parecem querer manter a fome de inovação política sob uma dieta suficientemente restrita, condicionada a um regime de identidade cultural e politicamente pouco flexível.

Os termos que definem a metodologia do FSM, e sua aplicação dita horizontal são marcados pela perspectiva, no mínimo discutível, de que um "espaço aberto" pode ser livre de relações de poder (Biccum, 2005). A mesma concepção parece colocar o aperfeiçoamento e a reprodução do 
próprio Fórum - reconhecido como objetivo último das ações do Conselho Internacional e do Comitê Organizador/Secretariado Internacional - como um objetivo que se quer supra-político. Como afirma Cândido Grybowsky, “a ação política é responsabilidade de cada indivíduo e das coalizões que eles formam, não um atributo do Fórum” (apud Teivanen, 2009, p. 95). No entanto, como procuramos demonstrar ao longo do capítulo, as evidências do caráter político das ações implicadas no desenho da metodologia dos Fóruns e em toda a empreitada de sua realização, não são difíceis de encontrar.

Os mecanismos de consulta incorporados à metodologia do FSM em 2003 e 2005, por exemplo, caminham na direção de reforçar a perspectiva sintetizada na fala de Grybowsky que acabamos de citar, segundo a qual a organização dos Fóruns não deve ser (ou pelo menos não deve parecer) politizada. Uma vez que a dimensão política implicada na definição de um temário é amplamente reconhecida, é preciso que as instâncias organizativas tomem certa distância dessa tarefa. Até onde pude investigar a respeito do processamento das informações geradas pelas consultas temáticas que precederam as inscrições em 2003 e 2005, foi raro, senão nulo, o aparecimento de formulações que já não fossem identificados a um movimento ou setor integrado às instâncias facilitadoras do processo e reconhecidas pelos organizadores como parte do escopo do FSM. Se a consulta continuou a ser realizada pelo menos até 2009, isso não se deu pela contribuição renovadora que ela trazia aos conteúdos do temário, mas fundamentalmente como recurso que deveria expressar uma "metodologia mais participativa". A participação através da consulta não definia sozinha os temas do Fórum, mas fornecia à Comissão de Metodologia matériaprima legitimada para a produção das formulações finais. Segundo os documentos de metodologia de 2003, o objetivo desse mecanismo não era encontrar formulações totalizantes mais precisas, mas dar a ver o melhor possível a diversidade de presenças e demandas que o Fórum Social Mundial era capaz de reunir em um mesmo evento.

O FSM se complexifica ao longo dos cinco anos tratados por esta pesquisa, não no sentido de estabelecer uma direção comum, vista como precipitada e indesejável, mas na criação de mecanismos de produção de uma multiplicidade cada vez maior de "direções", tornadas equivalentes na metodologia e com o auxílio dela. As diferenças entre conferências, seminários e oficinas tendem a desaparecer em favor de uma "horizontalidade" das iniciativas. Embora, na prática, as diferenças de alocação de recursos e visibilidade permaneçam vivas, em termos metodológicos todas as entidades participantes, seus interesses e orientações políticas, tornam-se equivalentes. Nesse plano, parece fazer sentido a consideração de Boaventura Santos sobre aquilo que chama de "transconflitualidade" operante no Fórum: 
excluem-se à partida a acumulação e o aprofundamento de divergências que poderiam resultar do facto de os movimentos se alinharem ao longo de clivagens múltiplas. Muito pelo contrário, as clivagens acabam, assim, por se neutralizar umas às outras (Santos, 2005b).

O próprio Comitê Organizador das primeiras edições assume progressivamente a definição de "Comitê facilitador": aparentemente, não se trata mais de estabelecer ordens, mas simplesmente garantir o nivelamento de todas as atividades no plano metodológico.

Ao mesmo tempo, o aumento no número de eixos e a sofisticação dos enunciados, que podemos acompanhar no Anexo B, estão vinculados à necessidade de gerar maior consenso, supondo que um vocabulário mais diversificado pudesse produzir a identificação de um número maior de grupos e organizações ao temário. Na contramão da proposta de uma forma organizativa "neutra" e "horizontal", a lógica desses eixos se torna progressivamente "participativa", mas segundo uma lógica de representação. É de extrema importância para as organizações participantes perceberem-se representadas nesse elenco de conceitos, ouvir a voz de seus representantes e líderes ecoando no caderno de programação, único documento final que o Fórum Social Mundial produzia a cada ano, antes mesmo de acontecer. Para as instâncias organizativas, o fato de que mais participantes, setores ou instituições percebam-se representados é uma fonte de legitimação para o conjunto de suas definições metodológicas.

Ainda que a metodologia proponha uma horizontalidade independente de conteúdos políticos, os usos do espaço definidos pela arquitetura da programação produzem hierarquias, como indicamos ao longo do capítulo. Sem considerar isto, como explicar, por exemplo, os protestos dos participantes pela ausência de uma determinada atividade no programa? Ou as revoltas pelo direito aos crachás? Ou a indignação de algumas organizações por acreditarem não terem sido contemplados com uma sala à altura de sua atividade? Ou, ainda, os sentimentos de profunda injustiça experimentados por organizadores de atividades autogestionadas que tiveram suas iniciativas mal divulgadas, com erros de horário ou local?

Poderíamos pensar que as pessoas que em todas as edições do Fórum dirigiram reclamações e protestos deste tipo aos funcionários e pessoal de apoio dos eventos fossem indiferentes ao espírito de comunhão e convergência esperado de "um outro mundo possível", ou que estivessem desinformadas do "verdadeiro sentido" da metodologia do FSM. Isto nos parece uma crítica fácil. Mais preciso é considerar que o avesso da metodologia do FSM é a sua conversão em um processo periódico de distribuição de parcelas de visibilidade, cujo efeito de produção de diferenças - que a "velha" perspectiva estratégica nos convidaria a chamar simplesmente de fragmentação - não é irrelevante. 
Enquanto nas duas primeiras edições a metodologia pareceu dominada pela perspectiva de produção de uma síntese que apresentasse ao mundo a clivagem política existente entre o povo de Porto Alegre e seus antagonistas de Davos, nos anos seguintes o temário abriu espaço à nomeação e à descrição mais extensa das disposições das entidades participantes. Mostrar essa diversidade torna-se um princípio prioritário desde, pelo menos 2002. A partir daí, a prioridade de tornar visíveis as iniciativas e alternativas propostas por todos exerceu uma inegável pressão para que a metodologia do Fórum assumisse uma forma cada vez mais enciclopédica, vide as centenas de páginas do caderno de programação de $2005^{37}$.

$\mathrm{Na}$ medida em que as formulações temáticas passam a ser elaboradas a partir de consultas, parece não haver mais nenhuma razão para que formulações particulares, adjetivações e qualificações específicas sobre os assuntos das atividades ficassem de fora. Como ressalta Janet Conway, é próprio de forma pluralista e não deliberativa permitir que as entidades participantes tornem-se visíveis umas diante das outras “em seus próprios termos” (2008:3). Atender a essa diversidade de expressões e possibilitar diferenciações internas torna-se o primeiro objetivo na construção dita participativa da programação de um Fórum Social Mundial, e as organizações participantes parecem ávidas em ver os termos de suas próprias formulações visíveis no programa oficial. É importante ter presente que, muitas vezes, a captação de recursos para a produção de uma atividade - cada vez mais explicitamente a cargo das organizações participantes - poderia depender ou ser facilitada pela especificidade de uma formulação, inspirada por exemplo por linhas de projeto e programas de apoio de uma instituição de cooperação internacional ou órgão estatal.

Como já sugerimos, é muito difícil dizer onde terminam as "normas de uso" de um espaço político e onde começam as relações de propriedade deste espaço, se é que é possível, de um ponto de vista político e antropológico, concebermos regras de uso que não tenham impacto sobre as ações que se dão em um espaço ou a partir dele. O Fórum Social Mundial não é uma exceção a essa dificuldade. Não é por acaso que Jai Sen compara o desenvolvimento do FSM em 2009 a uma espécie de setor imobiliário - "the Forum is now real state" - em que relações de propriedade são afirmadas "subliminarmente", lançando mão da referência a uma inflação da dimensão metodológica e à lógica de territorialidades que ela impulsiona (2009, p. 176). Em outras palavras, no caso do Fórum Social Mundial, a gestão metodológica dita "horizontal" dificilmente dissimula as disputas pela apropriação deste "espaço aberto" e das visibilidade que ele proporciona. A própria metodologia do Fórum, sobre a qual procurou-se construir unidade e consenso, pode ser entendida

\footnotetext{
37 "O caderno da programação do FSM era assustador. Maior que o Estadão de domingo, e isso para três dias de evento", comenta o jornalista Lucas Rodrigues Pires, em sua coluna no site Digestivo Cultural em fevereiro de 2005. Disponível em: http://www.digestivocultural.com/colunistas/imprimir.asp?codigo=1559
} 
como uma estratégia de apropriações. Se reconhecermos seu caráter político, é possível notar que ela escorrega para uma tecnologia de gestão dessas disputas por espaço e visibilidade, através de formas e categorias, mais familiares às experiências políticas que o antecedem do que seus fundadores gostam de admitir. A metodologia do FSM é em si mesma um modo de poder que condiciona as experiências políticas na medida em que as inscreve em uma programação, uma "arquitetura de processo".

Devemos lembrar, ainda, que as nuances cada vez mais refinadas presentes nos eixos de proposição de atividades e mais tarde nos eixos transversais, não conduzem necessariamente a aproximações políticas, nem são capazes de gerar por si mesmas condições de "convergência". Pude acompanhar de perto o crescimento de algumas alianças de grande densidade política ao longo dos cinco primeiros anos do Fórum, em particular a aproximação entre dois movimentos internacionais organizados em redes de grupos de base, a Via Campesina e a Marcha Mundial das Mulheres.Testemunhei também a construção de relações políticas e simbólicas relevantes entre a crescente visibilidade internacional da Marcha Mundial no Fórum e o engajamento de mulheres jovens, mobilizadas em torno de protestos antiglobalização, que descobriam no feminismo espaços criativos de militância. No caso da aproximação das jovens com o feminismo, o processo deu-se em grande medida, como uma pressão pelo descentramento da posição da Marcha Mundial das Mulheres (entidade membro do Conselho Internacional desde sua criação e do Comitê Organizador Brasileiro do FSM 2005) em relação ao próprio Fórum. Na mesma medida, intensifica-se, em 2003, a presença deste movimento no território então marginal do Acampamento da Juventude (Di Giovanni, 2003).

Quanto à relação entre a Marcha Mundial das Mulheres e a Via Campesina, (cuja complexidade não poderá ser explorada mais a fundo neste trabalho), vale a pena destacar que uma das expressões da aproximação dos dois movimentos no âmbito do Fórum foi a defesa da posição conjunta no interior do Conselho Internacional, em favor da revisão da periodicidade dos eventos. Representantes dois movimentos sustentaram, juntos, a proposta de que o Fórum Mundial passasse a ser realizado a cada três anos, a partir da avaliação comum de que o ritmo acelerado da produção anual de megaeventos competia com a árdua agenda de embates locais e internacionais estratégicos - como a luta pela terra, pela soberania alimentar, contra o capitalismo patriarcal, a militarização e a mercantilização- travados fora dos limites do FSM (Di Giovanni, 2004). Aqui também, a convergência aparece como um deslocamento dos participantes em relação à suposta coerência metodológica do Fórum, ao mesmo tempo em que revela a percepção de que os debates sobre seu sentido político estão sendo travadas no campo da "forma" Neste caso, uma disputa a respeito da 
relação entre os eventos e as lutas locais e cotidianas de pequenas organizações de mulheres e movimentos do campo, está sendo travada sob a rubrica da periodicidade dos encontros.

Em ambos os casos, as aproximações políticas entre grupos que permitiram ganhos de visibilidade, capacidade de mobilização e ocupação de espaços no FSM, são inseparáveis de relações anteriores, tecidas à revelia das disposições metodológicas. Em particular, as alianças mencionadas acima foram animadas por perspectivas estratégicas particulares e por um claro distanciamento crítico em relação aos rumo do Fórum como processo, e não promovidas pela simples adesão às regras de uso definidas pela metodologia. Uma grande variedade de relações de confiança, de causas compartilhadas, de parcerias táticas de captação de recursos, de pequenas redes locais de relações entre militantes, de origens geográficas e históricas comuns, e estratégias conjuntas parecem escapar aos termos da metodologia. Dificilmente um método de convergência e aglutinação teria podido se sobrepor, ou reverter, a complexidade das relações políticas externas ao universo do Fórum. A noção de "diversidade", tomada como princípio, nada diz sobre essa histórias.

As atividades realizadas conjuntamente por diversas das organizações que tomaram parte das edições do FSM em Porto Alegre não resultam necessariamente, nem frequentemente, da mecânica metodológica interna ao evento. São, antes, resultado e continuidade de campanhas e esforços permanentes de formação e construção de relações de confiança. O que a realização do evento FSM proporciona, sem dúvida, é a concentração de recursos, interesses e meios de comunicação, fundamentais para que esses processos mais permanentes sejam apresentados publicamente.

A realização periódica do FSM oferece a muitas redes condições de visibilidade e oportunidades de arrecadação de recursos que possibilitam encontros presenciais, fundamentais para a construção de relações de confiança em contextos de formação de redes internacionais de militância - como é o caso da Marcha Mundial das Mulheres e da Via Campesina. Além do reforço aos processos de articulação interna aos movimentos, o FSM possibilita que movimentos e redes interessados em que suas linhas de ação já em curso possam reforçar-se mutuamente tenham um espaço concreto, reconhecido como polo de proposição de uma ordem mundial alternativa, de onde estabelecer uma pauta e um calendário de mobilização para o ano seguinte, além de lançar chamados internacionais à ação. Assim se constituiu, no interior do espaço "neutro" do Fórum, a Assembleia Mundial dos Movimentos Sociais, cuja iniciativa mais notável foi alinhar a data para os protestos contra a invasão do Iraque em 15 de fevereiro de 2003 - até hoje a maior manifestação política de rua articulada em nível internacional de que se tem notícia (Azzi, 2007). 
Iniciativas como as Assembleias dos Movimentos Sociais, no entanto, parecem ter ameaçado o equilíbrio da aglutinação e da convergência tal como desenhadas pela metodologia do Fórum. As Convocatórias dos Movimentos Sociais lançadas nos eventos de 2002 e 2003 causaram profundo desconforto para os defensores do Fórum como método e como "espaço aberto" (Waterman, 2009). Divulgadas ao final dos eventos, as declarações da assembleias podem se tornar mais visíveis que "o próprio FSM" ou mesmo serem tomadas por declarações oficiais, colocando em risco a neutralidade política do Fórum espaço. Em 2005, um painel de alternativas foi criado para a divulgação de todas as conclusões e declarações elaboradas ao final do Fórum, um grande mural-corredor, instalado em local de grande circulação, concebido "para aumentar o caráter propositivo do FSM" (“A nova cara do FSM”, 2004). O painel, que traremos novamente à análise no próximo capítulo, parecia repetir mais uma vez o gesto de nivelamento de todas as vozes e iniciativas sob a ordem metodológica de uso do espaço.

Em 2005, quando regras de uso são implantadas em territórios físicos, os temas, eixos e subeixos multiplicam-se, e as atividades passam a depender exclusivamente da iniciativa das entidades proponentes (e não da iniciativa do Comitê Organizador), encerra-se o evento com um discurso que descreve um Fórum completamente horizontal e autogestionado: "Este ano, a autogestão permeou todas as práticas, desde o primeiro momento. E assim, em vez de eventos com grandes palestras, houve uma discussão horizontal, plural e democrática de uma multiplicidade de temas"(Cerimônia de Encerramento, 2005). No entanto, as percepções dos participantes, mesmo os mais entusiastas, não necessariamente reforçam este sentido: "Mas verticalmente, este foi o grande momento das articulações entre entidades, redes, associações, ONGs e agremiações políticas de todo o mundo. Cada um veio procurar sua turma." (Maringoni, 2005).

No Território Social Mundial produz-se, para muitos participantes, a clareza de que chegara o momento de aproveitar a visibilidade gerada pelo evento, não para dinamizar a confluência de todas as iniciativas ali reunidas, através de aglutinações temáticas, mas para reunir seus aliados e impulsionar processos e objetivos políticos específicos. Uma vez que os conceitos ganham uma localização precisa no mapa de Porto Alegre, grupos e afinidades políticas também tendem a uma sedentarização. Não foi difícil que dinâmicas intensas fossem produzidas entre as entidades participantes, que vinham construindo iniciativas em parceria fora do processo Fórum; mas interesses diferentes, grupos que não tivessem nenhum tipo de contato prévio ou que simplesmente não desejassem compartilhar coisa alguma, terão passado perfeitamente alheios uns aos outros em sua circulação no território Social Mundial, mesmo que tenham chegado ali através do sofisticado processo de definição de temas e aglutinação. Uma vez que a metodologia parece operar com base em um sentido de dispersão das vozes mais nítidas, em prol da valorização dos participantes em sua 
pluralidade e diversidade, os grupos que constituem agendas e tem convocatórias a propor - como é o caso da Assembleia dos Movimentos Sociais - tendem a buscar usos cada vez mais parciais do Fórum Social Mundial (Azzi, 2007). Tomadas estritamente nos termos das regras metodológicas que pretendem fazer do Fórum um espaço político sem conflitos, as dinâmicas de aglutinação e convergência tendem a reduzir-se, progressivamente, a uma série de procedimentos para garantir as estruturas de encontros previsíveis e estrategicamente calculados, fornecendo, sob a aparência de uma grande praça sem divisões internas, todas as indicações necessárias para que cada um "procure a sua turma".

Se no plano das práticas se observam diferenças, dissidências e contradições, no nível das análises e balanços nota-se, em geral, tentativas de ordenamento binário das discussões internas sobre o funcionamento do FSM: "Fórum como movimento" versus "Fórum como espaço"; "horizontalistas" versus "verticalistas" (Whitaker, 2009; Teivanen, 2009; Rabelo, 2006). Ainda que seja preciso considerar o contexto e alvos heterogêneos desses discursos de modo a melhor analisálos, não parece exagerado notar que o recurso às oposições simples tende a mascarar o fato de que a metodologia "horizontalista" do FSM foi produzida de maneira centralizada e nunca esteve livre de "verticalismos". Como já indicamos no capítulo I, a dinâmica da definição dos usos do espaço político, que ganha o nome de metodologia e se funde progressivamente a escolhas de caráter “operacional", não é de forma alguma irrelevante do ponto de vista estratégico, ou seja, do ponto de vista das relações de poder. A atenção a essa dinâmica nos leva a ponderar sobre a validade, neste caso, das análises da ação política que partem de uma distinção radical entre a política orientada por uma lógica "horizontal", em que os efeitos são produzidos por associações parciais e pequenos gestos táticos, e a dita política "vertical”, definida por uma lógica de acúmulo linear, em que estruturas hierárquicas produzem a unidade de um corpo político e de sua ação (Nunes, 2005b).

No caso do Fórum Social Mundial, o horizontalismo pretendido pela metodologia e o nivelamento que ela perversamente promove não se opõem à acumulação estratégica de poder. Muito pelo contrário: é a defesa de procedimentos de "não totalização" que define uma totalidade e garante, ao longo do tempo, o acúmulo de poder daqueles que dominam a linguagem do método, manipulando as categorias que ele estabelece. Como afirma April Biccum, as formas alternativas (sociais, políticas, econômicas e culturais) que o FSM pode oferecer dependem inteiramente de como as questões estão sendo formuladas, e o modo de formulação das questões é justamente o que está em jogo na metodologia do FSM (2005, p. 127). Nas definições pretensamente neutras de uma metodologia do "espaço aberto" são definidas relações hierárquicas e de propriedade. Não por acaso, como afirma o próprio "Guia de princípios para la Organización de Eventos FSM", é em sua constituição como "método horizontalista" que o Fórum evoluiu para um certo tipo de "marca" 
(FSM 2008), uma etiqueta que se poderia legitimamente anexar a eventos que cumpram um certo modo de fazer. Essa "marca FSM", não é um traço que confirma uma origem comum no passado, nem o sinal profético que define para toda ação política que nele se inscreve um futuro comum. Ela certifica um Fórum enquanto estrutura sincrônica, como forma que possibilita ver a ação e as diferenças políticas não sequenciadas no tempo, mas justapostas no presente, distribuídas no espaço. 


\section{As formas da memória no Fórum Social Mundial}

Porque aqui, ainda mais do que antes, o tempo era um problema, visivel, tangivel, iniludivel. [...] Como, no sentido próprio da palavra, habitá-lo?

François Hartog 38

Na última noite do Fórum Social Mundial em 2002, houve muita festa no Acampamento da Juventude. Comemoravam-se novos planos para o futuro, novas amizades, amizades antigas capazes de sobreviver aos conflitos daqueles dias - muitos dias de trabalho árduo - a diversão, as ideias descobertas, a cidade temporária que habitamos. Havia fogueiras acesas, bebida, música. Não sei dizer que horas eram quando me recolhi para dormir em uma barraca emprestada, entre outras milhares de barracas, enquanto a festa de despedida seguia ruidosa.

Despertei na manhã seguinte na companhia de duas amigas, uma estudante de São Paulo e uma militante porto alegrense. Chovia torrencialmente lá fora. E qual não foi nossa surpresa, abrindo o zíper do nosso abrigo de náilon para espiar a movimentação, ao descobrir que a Cidade da Juventude Carlo Giuliani já havia desaparecido quase completamente. As tendas, as redes, os vendedores de quinquilharia militante, as bandeiras, os varais de roupa, a vibração sem trégua dos alto-falantes, as cozinhas improvisadas, o vai-e-vem atarefado dos organizadores de atividades e as rodas de violão e de debates haviam cedido lugar a um imenso terreno alagado onde flutuava nossa barraca, sobre uma ilha de pedaços de carpete roubados de algum escritório. Tudo que pudemos fazer foi esfregar os olhos, acender cigarros e contemplar a chuva, conversando longamente sobre o que tínhamos vivido e sentido daquele mundo tão intenso e que tão prontamente se dissipara. "A gente sabe", disse a moça de Porto Alegre, que passara meses absorvida na preparação do acampamento e na organização de atividades, "que daqui a alguns anos vai chegar a hora de destruir isso que a gente está construindo". Enquanto a chuva funde os restos da festa à lama do chão do parque, a experiência política recente parece inscrever-se no tempo passado. Na medida em que a experiência toma forma e lugar na dimensão da memória, perguntas novas e inquietantes podem ser formuladas pelas pessoas que dela tomaram parte. O que vamos querer demolir daquilo que nós mesmos ajudamos a criar? Dos projetos e das experiências compartilhadas, o que será preservado? "O que destruir, o que conservar, o que reconstruir, o que construir e como? Essas são decisões e ações”, dirá François Hartog, “que mobilizam uma relação explícita com o tempo” (2003, p. 20).

\footnotetext{
${ }^{38}$ Hartog, 2003.
} 
Nos capítulos anteriores, já nos aproximamos de algumas relações de temporalidade que marcam a experiência do Fórum Social Mundial, seja do ponto de vista da relação entre as definições de Fórum-evento e Fórum-processo, seja na perspectiva mais ampla das tensões entre metodologia e estratégia, entre práticas ditas "inovadoras" e suas projeções sobre passado e futuro. Este capítulo dedica-se à memória, entendida como um terceiro tema condutor da problematização dos sentidos do Fórum Social Mundial, remetendo diretamente às relações entre a experiência política e o regime temporal de que tal experiência é produto e produtora. Também através de seus diferentes modos de guardar e perder, de lembrar e esquecer, os participantes e organizadores vão produzindo o FSM como experiência política singular.

A memória, assim como a estratégia e a metodologia, não é um dado, mas uma noção composta por e sujeita a diferentes usos, na passagem entre os "fóruns" e "o Fórum", este que se enuncia como uma unidade processual ou espacial. Do mesmo modo que as noções que consideramos nos capítulos anteriores, memória é um termo fundamental, recorrente em textos e falas desde a realização do primeiro evento em Porto Alegre. Ao longo dos cinco anos enfocados por esta pesquisa, houve várias iniciativas definidas como "de memória" do Fórum, algumas delas vinculadas às instâncias organizativas do processo, outras não; algumas públicas, outras privadas. Essas iniciativas e seus destinos nos oferecem um ponto de vista privilegiado para pensar como a constituição do FSM - conjunto heterogêneo de modos de fazer e de pensar a política - é feita também de modos particulares de pensar e viver o tempo, de entender as relações entre passado, presente e futuro. Muito diferentes entre si, mais ou menos formalizadas, as iniciativas "de memória" falam sobre como participantes e organizadores do FSM esperam que suas experiências sejam lembradas (ou esquecidas): o que é o Fórum, quando já é passado?

A partir do tema da memória, voltamos assim a pensar sobre o problema de como o continuum da experiência ganha significado na medida em que é recortado por por formas específicas de ação e de discurso, buscando analisar agora sua dimensão temporal. Como vimos no primeiro capítulo, o próprio conjunto textual das análises e balanços constitui o principal material da sessão "Memória do FSM", no site mantido pelos organizadores brasileiros. Ao mesmo tempo em que ocupa uma posição privilegiada - estratégica - na criação do processo Fórum, a palavra escrita está longe de ser o único modo de inscrição dessa experiência no tempo. Não será possível, aqui, fornecer um catálogo exaustivo das formas da memória do FSM, mas buscaremos nos deter em algumas delas, na medida em que nos oferecem novos pontos de vista para descrevê-lo e problematizá-lo.

Chamam atenção, em primeiro lugar, formas da memória notavelmente correlatas ao sentido de espacialização que discutimos no capítulo anterior, quando apresentamos a centralidade da noção 
de metodologia e sua transformação, de um desenho conceitual ou temático, em um desenho territorial, arquitetônico, projetado sobre a superfície urbana de Porto Alegre. Além do mapa, forma fundamental da memória dessa territorialização, mas ainda no bojo das discussões sobre metodologia, os participantes e organizadores recorrem a uma série de figuras bidimensionais, como o mosaico, o mural ou a rede, para expressar a coesão política do Fórum e imaginá-la como algo passível de ser preservado no tempo. Este nexo horizontal, como veremos a seguir, mantém a memória fundamentalmente atada à concepção do Fórum enquanto método, concebida em um regime de acúmulo, expansão ou aprimoramento. E, assim como a redução do sentido do Fórum Social Mundial ao plano metodológico dissimula a densidade das relações políticas a que ele diz respeito, esse imaginário de justaposições horizontais deixa de fora outras formas da memória: restos que se dispersam, que não se encaixam em murais ou mosaicos; perambulações resistentes a mapeamentos; relações e espaços afetivos profundos, que não se esgotam na metáfora da "rede". Esses vestígios do FSM não se fixam a nenhuma superfície legível, mas permanecem impregnados em corpos e gestos, inseparáveis da própria vida. Estranhos a qualquer regime de memória concebido como acumulação, preservam em sua natureza sutil e dispersiva outros, inexplorados, sentidos políticos daquelas experiências.

\section{A memória horizontal}

Em um Fórum que "não fala", a primeira a falar é, mais uma vez, sua própria forma: a memória não se desvencilha dos princípios e da arquitetura conceitual que vimos ser fundamentais para conferir à experiência do FSM uma unidade de sentido. Não havendo declarações finais totalizantes, a memória do Fórum Social Mundial surge, muitas vezes, em meio a debates sobre como se pode conservar no tempo uma mensagem política. Ela estaria ligada, no mesmo sentido, ao compromisso expresso pela Carta de Princípios de difundir amplamente, "sem direcionamentos, hierarquias, censuras e restrições" as decisões que as entidades participantes venham a tomar durante os eventos (Carta de Princípios, 2001). Em um primeiro momento, a memória aparece concebida como um conjunto de ferramentas que permitem, passados os eventos, dar permanência e visibilidade à grande multiplicidade de atores, atividades e mensagens que constituem o Fórum, sem jamais confundir-se com ele.

Em janeiro de 2003, após a realização do terceiro FSM em Porto Alegre, o Conselho Internacional define como uma de suas funções "assegurar a sistematização da memória do processo" ("Resoluções da reunião do Conselho Internacional 21 e 22 de janeiro de 2003”, 2003). Alguns meses mais tarde, em reunião realizada em Miami (Estados Unidos), o Conselho, buscando deixar mais claras suas tarefas e responsabilidades, cria seis comissões de de trabalho. O tema da 
memória então, passa a integrar os trabalhos da Comissão de Conteúdos, definida nos seguintes termos:

coleta (memória), sistematização (análise e organização temática) e divulgação entre os participantes do processo Fórum por meios eletrônicos, publicações escritas e organização de seminários de discussão, de análises e propostas de novas iniciativas e alternativas para a resistência ao neoliberalismo e a construção de "um outro mundo possível" (Regras de funcionamento do CI do FSM, 2003).

Neste mesmo momento em que ganha maior destaque entre as funções do Conselho Internacional, a "sistematização da memória" também começa a aparecer no elenco de tarefas da Secretaria. Não por acaso, essas definições têm lugar em seguida à decisão do Conselho pela realização do FSM 2004 em Mumbai, momento em que a "continuidade" torna-se um tema de primeira ordem, em torno do qual crescem também as preocupações de consolidação da metodologia. O escritório que coordenava a realização dos eventos no Brasil e o próprio Comitê Organizador Brasileiro recebem, então, mandatos internacionais e permanentes de "facilitação": a eles é atribuído o título de Secretaria Internacional do Processo FSM bem como a tarefa de transferir aos organizadores indianos competências sobre a realização dos fóruns anteriores, zelar pela integridade de seu método e pelo cumprimento da Carta de Princípios. A importância do método coincide com a ideia de continuidade e integridade do espírito de Porto Alegre, tendo desdobramentos importantes na concepção e definição de tarefas ditas "de memória".

A partir desse momento, nos documentos do Conselho Internacional, de maneira geral, e nos documentos de metodologia em particular, a memória aparece em companhia de reiteradas afirmações sobre a importância do prisma da diversidade que caracteriza o método Fórum, em seu movimento permanente de expurgar formulações consideradas totalizantes. As referências à memória vinculam-se também, crescentemente, à noção de sistematização: um procedimento percebido como exigência e extensão da própria metodologia Fórum. Neste sentido, a atividade fundamental da memória, tal como definida no documento de 2003, é "coleta": ela supostamente não gera materiais, apenas recolhe algo que se produz na sucessão dos eventos e na consolidação de estruturas organizativas permanentes. No entanto, o trabalho não se encerra aí: esses conteúdos devem ser ordenados, sob a forma de um sistema que os torna inteligíveis - eles devem ser sistematizados.

O termo sistematização, difundido a partir de seu uso no vocabulário das ONGs, sindicatos e movimentos sociais brasileiros, foi incorporado à linguagem cotidiana da organização do Fórum simultaneamente à consolidação das noções de processo e método. $\mathrm{O}$ termo é inclusive transposto sem cerimônia a outros idiomas, a palavra systematisation frequenta boletins de preparação e 
documentos do Conselho Internacional em língua inglesa, ao lado de outros substantivos inusuais como aglutination, ou articulation. Tal como aparece no Fórum Social Mundial, esse uso do termo sistematização parece ser parente próxima do modo difundido desde os anos 80 entre os atores da sociedade civil brasileira e de programas de desenvolvimento latino-americanos, vinculado ao paradigma da educação popular. Segundo Plannels, no começo da década de noventa, em um contexto de crise marcado pela vitoriosa implementação de políticas neoliberais e pelo chamado "fim do socialismo real”, "organizações de educação popular começam a teorizar e a implementar iniciativas de sistematização de experiências que, inicialmente aplicavam sobretudo aos programas de educação popular em que trabalhavam” (2007, p. 623). No contexto dos embates pela democratização política, de defesa dos direitos humanos ou da emergência das questões de gênero, a referência da sistematização como método extrapolou as dinâmicas internas dos movimentos, tendo impacto institucional e sobre políticas de educação da região, e tornando-se um eixo para a realização de encontros e para a formação de redes internacionais - antecessores do FSM que certamente forneceram parâmetros práticos e teóricos para sua constituição. $\mathrm{O}$ termo é empregado como sinônimo de processos de produção de conhecimento que pretendem ser não impositivos, fundados na valorização das diferenças, devendo aperfeiçoar-se ao longo do tempo de maneira a incorporar, e não suprimir, a diversidade de pontos de vista e a natureza plural de todas a experiências.

A ideia da sistematização, tal como apropriada no contexto do FSM, não necessariamente reflete as práticas e a conceitualização elaborada pelas organizações latino-americanas ao longo dos anos 80 e $90^{39}$. Trata-se, no entanto, de uma referência importante do imaginário do "diálogo permanente" que anima a concepção do Fórum Social Mundial: entre as organizações participantes, na maioria brasileiras e latino-americanas, há uma familiaridade com a noção de sistematização e a percepção de que ela é importante. A sistematização seria o trabalho de extrair de uma experiência política multidimensional a substância capaz de "fortalecer" a construção do processo: devem fazer parte da memória os elementos capazes de inscrever os Fóruns em uma dinâmica de acumulação de saberes compartilhados, diagnósticos sobre o mundo, propostas de ação, mas principalmente conhecimentos sobre o próprio processo organizativos do FSM.

\footnotetext{
${ }^{39}$ Segundo Planells, as organizações pioneiras dessa proposta foram o Centro de Estudios del Tercero Mundo, do México, a Rede Alforja, integrada por organizações da região centro-americana, el Centro Latino-americano de Trabajo Social de Perú e o Consejo de Educación de Adultos de América Latina - CEAAL (Planells, 2007, p. 626). Como técnica de uma organização feminista brasileira, tive a oportunidade de participar de um processo de avaliação interna apoiado pela metodologia da Rede Alforja. Manuais e treinamentos de sistematização muitas vezes fazem parte da formação de lideranças da Central Única dos Trabalhadores (CUT) e do Movimento dos Trabalhadores Sem Terra (MST).
} 
No artigo de 2005, "Memória e «restituição» dos fóruns sociais", publicado originalmente na revista acadêmica francesa Matériaux pour l'Histoire de notre Temps, editada conjuntamente pela Biblioteca de Documentação Internacional Contemporânea e o Musée D'Histoire Contemporaine, Nicolas Haeringer, participante ativo da organização dos Fóruns Sociais Europeus e de comissões criadas pelo Conselho Internacional, fala em sistematização como um procedimento incorporado à produção da memória, como uma acumulação de saberes: sistematizar passa por selecionar traços passíveis de serem conservados e transmitidos. O artigo de Haeringer é possivelmente o único documento da família das análises e balanços que expõe argumentos e problematiza diretamente o tema da memória do Fórum, apresentando- o sempre vinculado às noções de sistematização e "restituição". A análise é elaborada a partir de uma busca por respostas a um diagnóstico de declínio do Fórum Social Mundial: ele estaria deixando de ser considerado um espaço em que se pudesse formular um projeto político "a um só tempo claro e global", falhando em oferecer indicações claras sobre a natureza do outro mundo possível almejado e sobre as estratégias necessárias para construí-lo (2005, p. 63). A memoria é concebida como um trabalho fundamental na prevenção do declínio político e condição para o salto qualitativo que separa a mera sucessão de eventos de um verdadeiro processo FSM: é preciso "dar a saber o que acontece", difundir ou socializar o que se passa, de modo a promover um "impacto" entre as organizações participantes e na "opinião pública".

Segundo o autor, em um seminário internacional sobre o tema da sistematização, realizado em Paris, em setembro de 2004, reunindo membros da comissão Systematize do Fórum Europeu e membros da Comissão de Metodologia do Conselho Internacional, foram identificados tipos de documentos que deveriam receber um tratamento prioritário na construção de uma memória do Fórum. Os registros resultantes da preparação dos eventos, informes, notícias, declarações provenientes seja dos organizadores, seja dos participantes em geral, são incluídas entre os conteúdos pertinentes. Também são considerados pertinentes os documentos "produzidos ou validados pelos atores do Fórum no âmbito de sua participação (textos de preparação de um seminário, conferências apresentadas e intervenções em mesas redondas, informes dos debates, relatos de oficinas, etc.)" (Haeringer, 2005, p. 65). Ficam de fora da sistematização, ou pelo menos são mantidos em segundo plano, os documentos "mais distanciados e analíticos": ensaios de balanço e críticas (Haeringer, 2005, p. 64) - conjunto semelhante ao material de análises e balanços que ampara o itinerário desta tese.

Devemos notar que os atores do Fórum no âmbito de sua participação nos eventos, ao contrário dos analistas que publicam suas opiniões a posteriori, onde quer que seja, são vozes autorizadas pela metodologia do FSM e por uma lógica velada de representação: são designados 
para ocupar postos de fala por organizações devidamente inscritas no evento, durante atividades igualmente inscritas na programação e validadas pelos organizadores. Também as lembranças e relatos considerados pessoais, ainda segundo Haeringer, não são considerados pertinentes: o artigo identifica como uma debilidade o fato de os Fóruns não tornarem visível aquilo de que são portadores, "senão através dos relatos, das lembranças ou testemunhos de seus participantes" (2005, p. 63). Uma vez que o Fórum é definido como espaço da "sociedade civil organizada" e não de iniciativas individuais, fica implícito no texto de Haeringer, bem como nos documentos do CI, que a memória passível de sistematização, reconhecida como parte do processo, é aquela que diz respeito a coletivos, movimentos, redes e organizações inscritos nos eventos. Tal como definida pelo seminário de 2004, a sistematização é, fundamentalmente, a identificação e a apropriação dos conteúdos inscritos na metodologia, os conceitos e o savoir-faire resultantes de cada evento, e seu re-investimento na preparação de novos Fóruns. Neste sentido, a operação de sistematizar corresponde a uma forma de memória que adere à "arquitetura do processo", participa das operações que estabelecem continuidades formais e políticas entre eventos particulares. A mesma relação está expressa na função de "restituição": restituir significa "inscrever os fóruns em uma dinâmica de saberes e conhecimentos compartilhados" (Haeringer, 2005, p.65). Os registros das experiências passadas e a captação do presente são algo a ser re-investido no "fortalecimento" da unidade processual e no aprimoramento da metodologia que rege essa unidade. Neste sentido, a memória permite que o processo fórum seja um processo acumulativo.

Nos debates do Conselho Internacional do FSM, a memória é fortemente carregada do sentido apresentado pelo artigo de Haeringer, formulada como uma realização avançada da estrutura processual e metodológica do Fórum. O informe "Metodologia do FSM 2004 (proposta preliminar)"(2003), elaborado pela Comissão de Metodologia, sugere a "sistematização" e a "memorização" como procedimentos para a melhoria da metodologia, que ajudariam a "fortalecer nossa rica diversidade":

A confrontação, o diálogo e o intercâmbio entre os diferentes precisam melhorar e,
sobretudo, temos de dar atenção especial à sistematização e à memorização do
processo. Isso também é responsabilidade de todos nós mas devemos desenvolver
uma metodologia e meios práticos mais apropriados para facilitar o registro e o
acesso subsequente ao conjunto de dados para toda e qualquer pessoa que quiser
consultá-los ("Metodologia do FSM 2004 - proposta preliminar", 2003).

Ao pé da letra, entende-se por memória a produção de um “conjunto de dados". Sistematizar e memorizar são aqui funções especiais da metodologia, "registro e acesso" são seus termos chave. O Fórum enquanto método deve ser aperfeiçoado pela memorização: seleção, preparação e 
circulação dos traços de experiência cujo "conteúdo" pode ser direcionado para realimentar uma dinâmica de multiplicação e expansão do "espaço aberto", um processo de "capitalização das experiências, das expertises e dos conhecimentos" a ser produzido à imagem e semelhança do processo Fórum: "aberto, inclusivo, evolutivo e diretamente controlado pelos atores envolvidos" (Haeringer, 2005, p. 66).

Entendida como resultado dos procedimentos de sistematização e/ou restituição, a memória do Fórum, tal como concebida por suas instâncias organizativas, torna-se um espelho da noção de metodologia. Um exemplo importante de como se dá essa mímese entre metodologia e memória são os murais de propostas criados durante os eventos de 2003 e 2005 (em 2003 apenas um, disponível para o conjunto das atividades, e em 2005 muitos, criados para cada um dos onze espaços temáticos). Nestes murais, as entidades participantes podem difundir os resultados ou deliberações das atividades que inscrevem e realizam no âmbito da programação do Fórum. Com ajuda de voluntários, estes resultados, propostas ou declarações, elaborados por escrito através de um formulário padrão (Anexo D) ${ }^{40}$, são afixados a uma superfície plana, onde se tornam acessíveis a todo o público do evento. Mais tarde, os conteúdos dos formulários são transcritos para um website especial, como parte de um projeto chamado Memória Viva. A função deste site é precisamente fazer com que as informações recolhidas durante o evento, tornadas públicas e disponíveis para consulta, sejam convertidas em material para a continuidade de diálogos e colaborações nascidas durante os eventos e para a preparação de novos fóruns. Na criação de mecanismos como o preenchimento de um formulário, a validação e o processamento de dados por funcionários-voluntários, coleta e disponibilização aparecem mais uma vez como procedimentos requeridos para a constituição da memória do FSM.

Aparentemente, tais procedimentos são considerados neutros, tarefa independente de deliberações políticas: os resultados das atividades, opiniões dos participantes e conteúdos são recolhidos enquanto informações a serem difundidas e, de alguma maneira, guardadas, sempre com importâncias equivalentes. A adesão a tais procedimentos é proposta às entidades também como uma possibilidade de ampliação de sua participação: o painel oferece espaço para aquilo que os promotores de cada uma das iniciativas auto-geridas queiram e possam mostrar a respeito do que fizeram. Assim como a montagem da programação depende das inscrições voluntárias, também o registro de realização das atividades depende da disposição dos participantes para inscrever seu relatos, mensagens ou propostas na memória do FSM. Neste sentido, o mural reforça o caráter pluralista do método e a autonomia dos participantes: a memória do Fórum assume a forma de um

\footnotetext{
${ }^{40}$ Anexo D, disponível em: www.forumsocialmundial.org.br/download/questionario_mural.pdf
} 
“espaço aberto" horizontal. Como afirma Francisco Whitaker, principal porta-voz da proposta dos murais:

\begin{abstract}
Além de divulgar as iniciativas, o mural também tem o intuito demostrar que o Fórum Social Mundial não tem um documento final, mas sim centenas de documentos que se originam das atividades desenvolvidas durante o encontro. Isso demonstra a diversidade das questões enfrentadas e das alternativas propostas por âmbito, setor ou problema (Francisco Whitaker apud Botelho, 2005).
\end{abstract}

O "Mural de Propostas de Ação" de 2003 - rebatizado em 2005 como "Mural de Propostas para a Construção de Outros Mundos" - é, assim, apresentado como um mecanismo de difusão, que atende à demanda de visibilidade para questões particulares de parte das entidades participantes. É preciso notar, no entanto, que o Mural parece responder também à inquietação em torno das declarações finais, às demandas internas e externas de que o Fórum deixe mais clara sua mensagem e "apresente alternativas". Como resposta a esse problema, o Mural tem um caráter de demonstração. Mais uma vez, as práticas de participação - agora no plano da memória - são exibidas como realizações dos valores da horizontalidade e da multiplicidade. O painel de propostas seria uma imagem do método aberto do Fórum ou o próprio método realizado como performance: a justaposição de inúmeras mensagens torna-se uma forma da memória que contribui para distinguir o FSM o das formas políticas consideradas velhas, nas quais o caráter e o conteúdo de um evento é atribuído a seu documento final.

Estamos diante de mais uma evidência de que, embora a Carta de Princípios recuse a instituição de uma voz única, a "mensagem" ou declaração final é um fantasma que custa em abandonar o centro do palco, assombrando também as questões relativas à memória do Fórum. Ela é uma preocupação permanente, já que, apesar das disposições ditas "horizontalistas" dos organizadores e de seus métodos preventivos, em um evento no qual são emitidas múltiplas declarações políticas, é difícil impedir que algumas mensagens se tornem mais visíveis que outras. Como aponta Diego Azzi, é o caso das declarações da Assembleia dos Movimentos Sociais:

que a cada Fórum traz um texto político e uma agenda de ações [...] Algumas vezes essas declarações foram tomadas, inclusive pela imprensa, como a declaração oficial do FSM, e a Assembleia como uma instancia decisória representativa do FSM. Porém, é importante observar que aí é muito difícil distinguir quais influências de discurso podem interferir mais: a relevância política que a atividade em si teve ou as incompreensões da imprensa sobre o próprio caráter de espaço horizontal do Fórum (Azzi, 2007, p. 139).

Como vimos nos capítulos anteriores, o propósito central da metodologia, voltada para diversidade interna do Fórum, é instituir um nivelamento das visibilidades e modular os ecos de 
todas mensagens. Uma memória informada pela metodologia parece girar em torno do problema de como equalizar, no tempo, o eco dessas mesmas vozes e visibilidades: como é possível impedir que uma voz - agora vinda do passado - torne-se mais audível que as demais? Como evitar que a própria memória torne-se uma declaração política, transformando-se em objeto a ser disputado pelos participantes? O mural ou painel aparece, em certa medida, como resposta a esses dilemas: preenche o lugar de uma declaração final, sendo ao mesmo tempo um mecanismo a prevenir que qualquer declaração possa ser tomada como final ou unitária. Consagrada como forma "oficial" da memória dos eventos, a forma mural pode ser lida a partir da mesma ambivalência que parece atravessar o processo FSM em muitos níveis: o que se define como aberto e horizontal é produzido a partir de "regras de uso" que excluem certos procedimentos e reconhecem outros como politicamente válidos.

Desde que não tenham pretensões de representar os demais os participantes, as inúmeras organizações, redes, e movimentos são até estimulados a emitir declarações finais parciais dos seus encontros e atividades, incluindo-as no mural de propostas, "cujo objetivo era dar uma (in)visibilidade homogênea aos resultados" (Azzi, 2007, p. 138). Por um lado, espera-se que o mural ajude a reatar o complexo universo de debates que se desenrola durante os eventos e a urgência de anunciar sentidos comuns para as ações concretas em curso no plano dos movimentos sociais. Por outro, ele é uma mensagem clara de que não se deve esperar do Fórum a produção de um sentido comum: sua realização final é uma exibição da pujante diversidade de propostas e intenções que ele é capaz de reunir ou, melhor, justapor, por no mesmo plano.

Embora essa morfologia só se tenha consolidado a partir de 2003, o nexo horizontal como forma da memória do FSM antecede a criação do mural de propostas, isso graças à importância política que a metodologia ganha na definição dos sentidos de um Fórum-processo,. Em 2000, na preparação para o evento de 2001, um escultor francês, Eric Théret, com apoio do Comitê Organizador, lança um pedido para que cada organização ou movimento inscrito no encontro trouxesse uma pedra para a composição de um mosaico, com o intuito de traduzir, segundo ele, "nosso desejo de estabelecer uma ligação com as civilizações do passado e as do presente" (Gianella, sem data). Antes mesmo da abertura do evento, as pedras começam a chegar. Alguns grupos ou organizações que não tinham trazido as suas, tratam de providencia-las. Mas as peças nesse mosaico não eram apenas pedras: aqueles que as trouxeram viram a necessidade de marcá-las com nomes de organizações, datas e mensagens, em sua maioria tinham a forma de placas. Como nenhum padrão havia sido estabelecido, alguns trouxeram pedras grandes, outras pequenas. Alguns, no calor da hora, vendo que muitos chegavam trazendo sua peça, improvisavam algo bem vistoso para não deixar de marcar presença na obra de Théret. O mosaico de 500 peças, vindas de 62 países 
- batizado de "Mosaico da Cidadania" - começou a ser montado provisoriamente em um lugar de passagem, à entrada do Centro de Eventos da PUCRS, durante o FSM 2001. As peças foram reunidas, dispostas no chão, e os intervalos entre elas preenchidos com areia de construção.

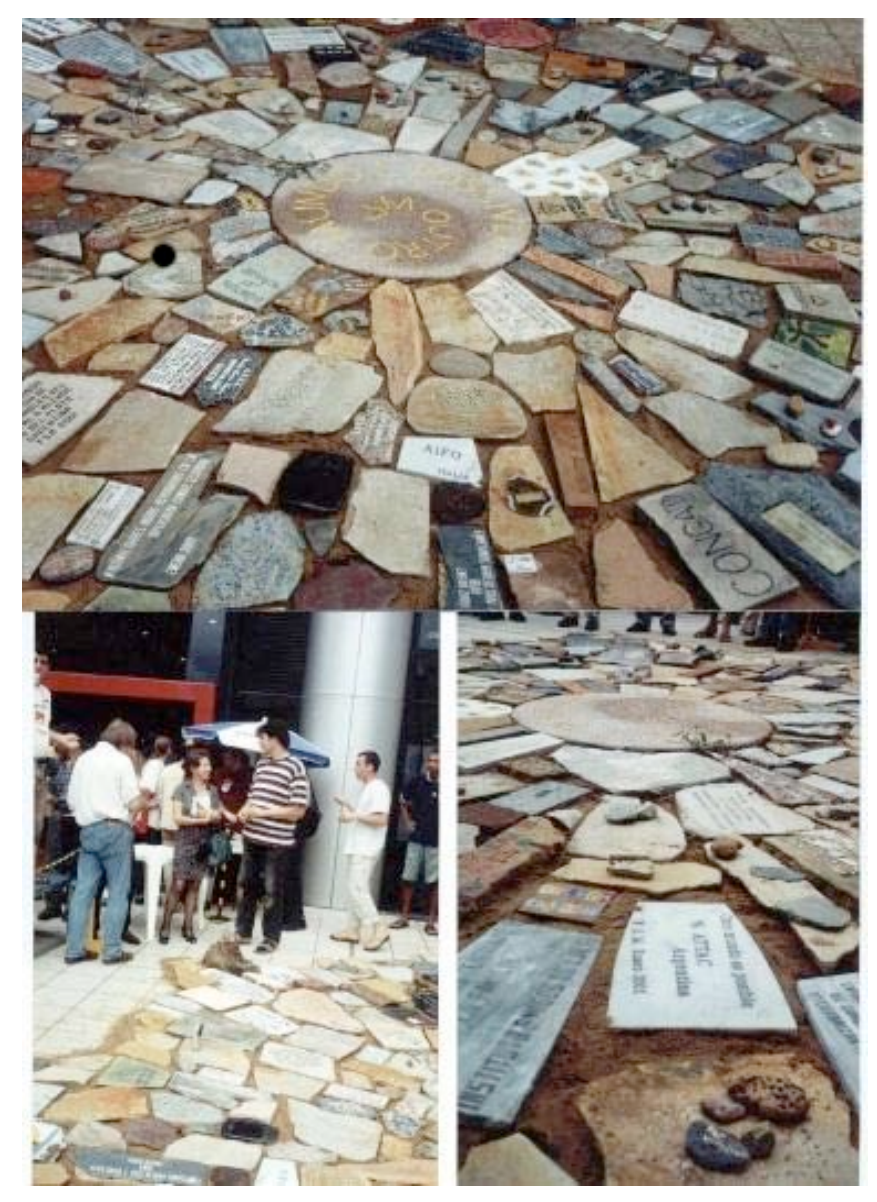

Figura 3.1

Montagem do Mosaico de Pedra durante o FSM 2001.

Foto: Miriam Gianella. Disponível em:

http://www.oedipe.org/po/actualites/alegre/mosaique

Entre os organizadores do primeiro FSM, a iniciativa está longe de ser uma preocupação de primeira grandeza, mas há bastante consenso sobre a necessidade de produção de símbolos da convergência entre diversos. Mais pedras são incluídas durante os eventos de 2003 e 2005, e o conjunto é instalado no Velódromo do Parque Marinha do Brasil, na Orla do Rio Guaíba, após a realização do Fórum de 2005.

Embora tenha sido concebido como uma instalação permanente, "de pedra" afinal, o mosaico acabou desaparecendo. Hoje o local não está sinalizado e não encontrei em minhas últimas viagens a Porto Alegre, alguém que me orientasse a fazer uma visita, ou sequer soubesse sua localização exata. Há boatos de que esteja danificado e mesmo que tenha sido removido ou 
enterrado. Mesmo que a composição de pedra de Therét tenha sido apagada do Parque ou esquecida por organizadores e participantes, a figura do mosaico tornou-se importante no Fórum Social Mundial.

Ao longo dos anos de realização do FSM em Porto Alegre, várias iniciativas relacionadas à memória estiveram baseadas na justaposição de objetos trazidos pelos participantes. Além do mosaico da cidadania, foi construído um "Painel dos Destinos Cruzados" em 2003, composto de "marcas" no tamanho máximo de uma mão, e uma Bandeira das Bandeiras, iniciativa surgida no Acampamento da Juventude, reunindo entre 2002 e 2004 bandeiras de movimentos e organizações de todo tipo em uma enorme peça de tecido, exibida durante algumas das marchas de abertura e encerramento dos fóruns. A expressão "mosaico de alternativas", que remete à justaposição de elementos diferentes entre si em um mesmo plano de visibilidade, é muitas vezes utilizada para representar o caráter de "espaço aberto", não hierárquico, do processo FSM. A forma do mural ou painel que os organizadores encontraram para tornar públicas as propostas políticas dos encontros é uma ressonância da mesma imagem. A figura parece ajudar a tornar presente o princípio de diversidade que viria a tornar-se fundamento da metodologia do Fórum, e expressa a ideia de que cada grupo ou organização poderia ali sentir-se parte de um conjunto maior, cujo sentido total resulta precisamente das diferenças entre as peças que o compõem ${ }^{41}$.

Também na memória do Fórum Social Mundial que encontramos sob a forma de mapas, o sentido de unidade na diversidade aparece afetado pela imagem do mosaico, da justaposição de segmentos. Mencionamos, no primeiro capítulo, que o tema da convergência dos diversos é trazido ao Fórum Social Mundial como uma das condições fundamentais da possibilidade de construção de um movimento anti-neoliberal em escala planetária. Tratava-se então de algo que tinha sido posto em prática nas ruas durante os grandes protestos contra as instituições multilaterais, associadas ao movimento antiglobalização: a unidade na diversidade era um princípio tático de ataque (Di Giovanni, 2012). Quando dizia respeito a coalizões formadas para a performance de um protesto de rua, a unidade na diversidade dizia respeito à ação, tinha sentido antes coreográfico que

\footnotetext{
${ }^{41}$ Talvez fosse possível imaginar também uma aproximação entre a figura do "mosaico social mundial" e o tipo de abordagem historiográfica que Aby Warburg buscava em seu Atlas Mnemosyne de imagens justapostas. Mas no atlas warburguiano, a montagem é guiada pela recorrência de um gesto, e não pela necessidade de composição estática entre elementos definidos por sua diferença irredutível. Nesse sentido, se nos painéis do Atlas Mnemosyne encontramos o mesmo procedimento de justaposição, é também preciso notar que sua vocação é menos pictórica que coreográfica. Cada imagem é dotada de densidade e de uma mobilidade inesgotável, estando livre para assumir protagonismo no conjunto a qualquer momento, às vezes à revelia da ordem prevista pelo observador, podendo fazer sombra sobre as demais, tornando-se chave para uma ordem de legibilidade inesperada. No mosaico de pedra ou no mural de propostas, a formação de um desenho, mesmo que abstrato e "em processo", depende em grande medida de que cada uma das imagens que o compõe permaneçam sempre niveladas: sua mobilidade é apenas bidimensional, não podem sobrepor-se umas às outras ou constituir um centro de atenções. Cada um dos elementos, em última análise, só pode fazer parte do conjunto na condição de peça estável, de fragmento de um plano que resiste a distorções. Se um pedaço saltar fora de seu encaixe, deixa de fazer parte do desenho total.
} 
cartográfico. O mapa dos protestos contra o Fundo Monetário Internacional em Praga, em 26 de setembro de 2000, por exemplo, é um registro da ação e movimento de grupos de manifestantes, tendo como objetivo comum transpor os limites do polígono formado pelas barreiras policiais que cercam o centro de conferências onde se dá a reunião oficial da instituição. As marcas de caneta feitas à mão em cores diferentes, representando o trajeto de diferentes grupos, são linhas de deslocamento, rotas de acesso e pontos de colisão - não propõem criar segmentações no território, e sim perturbar a separação entre as áreas de circulação comuns da cidade e o perímetro de segurança estabelecido pelas forças da ordem, onde a circulação e a expressão são proibidas.

Mapa de preparação do S26: as linhas desenhadas em azul, vermelho e amarelo indicam os trajetos de diferentes frentes protestos em Praga, Rep. Tcheca, contra a reunião anual do Fundo Monetário Internacional e do Banco Mundial (Di GiovannI, 2012).

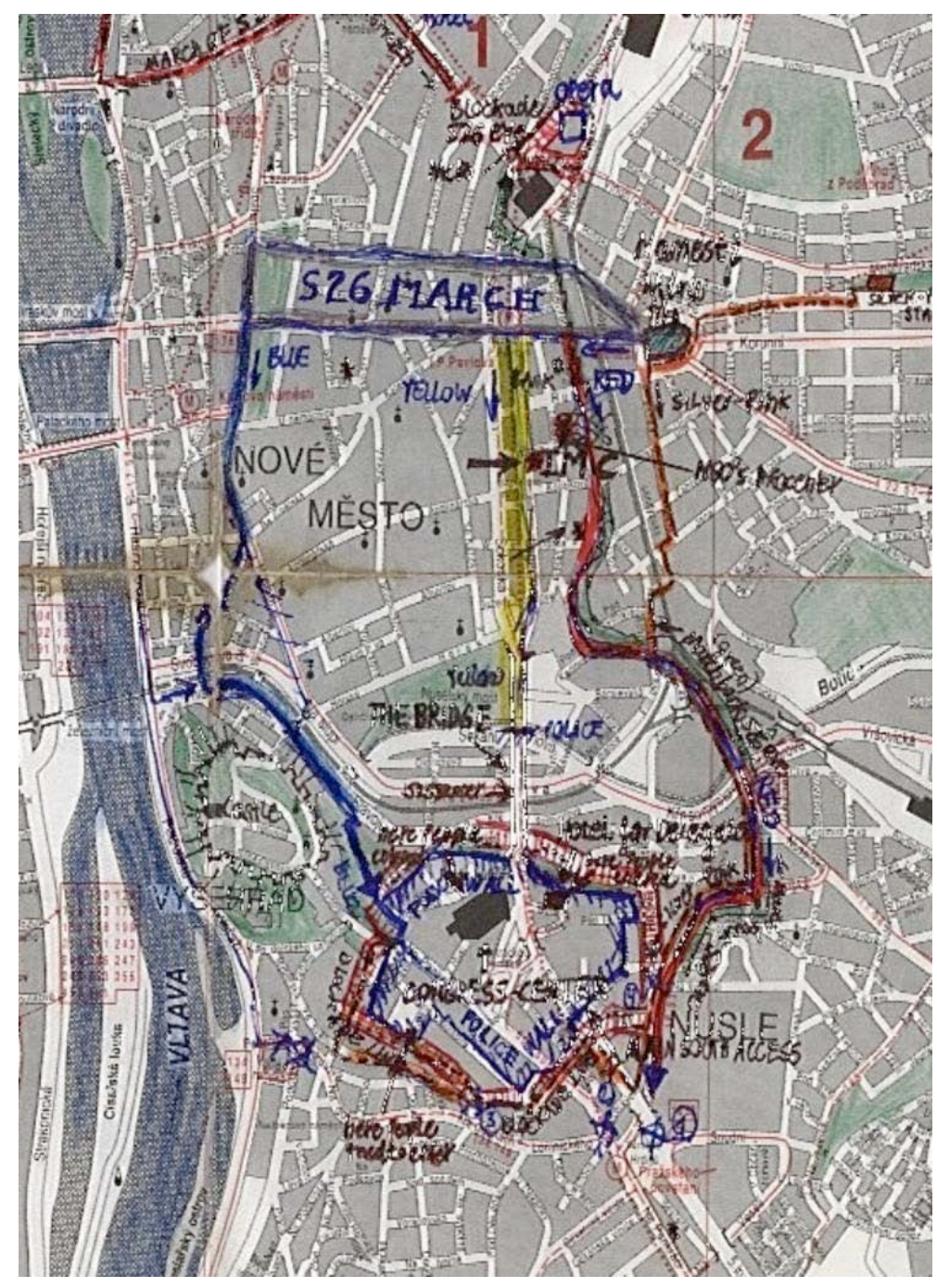

Figura 3.2

Fonte: Acão Global dos Povos - Arquivos de ProtestosDisponível em: 
http://www.nadir.org/nadir/initiativ/agp/s26/praga/map.htm

A forma Fórum, também em sua memória cartográfica, difere da forma protesto: o desenho fixo ganha precedência sobre o movimento. Nos mapas do Território Social Mundial de 2005, o lineamento é uma montagem fixa, que se sobrepõe ao espaço da cidade (aqui, um espaço em branco), criando fronteiras: as linhas de perímetro e transporte se dobram sobre si mesmas, integrando o território do Fórum e distinguindo-o do continuum urbano. As setas vermelhas desenhadas à mão durante o planejamento deste território indicam fluxos do público, cujos deslocamentos são fundamentalmente internos, obedientes ao perímetro temporário.

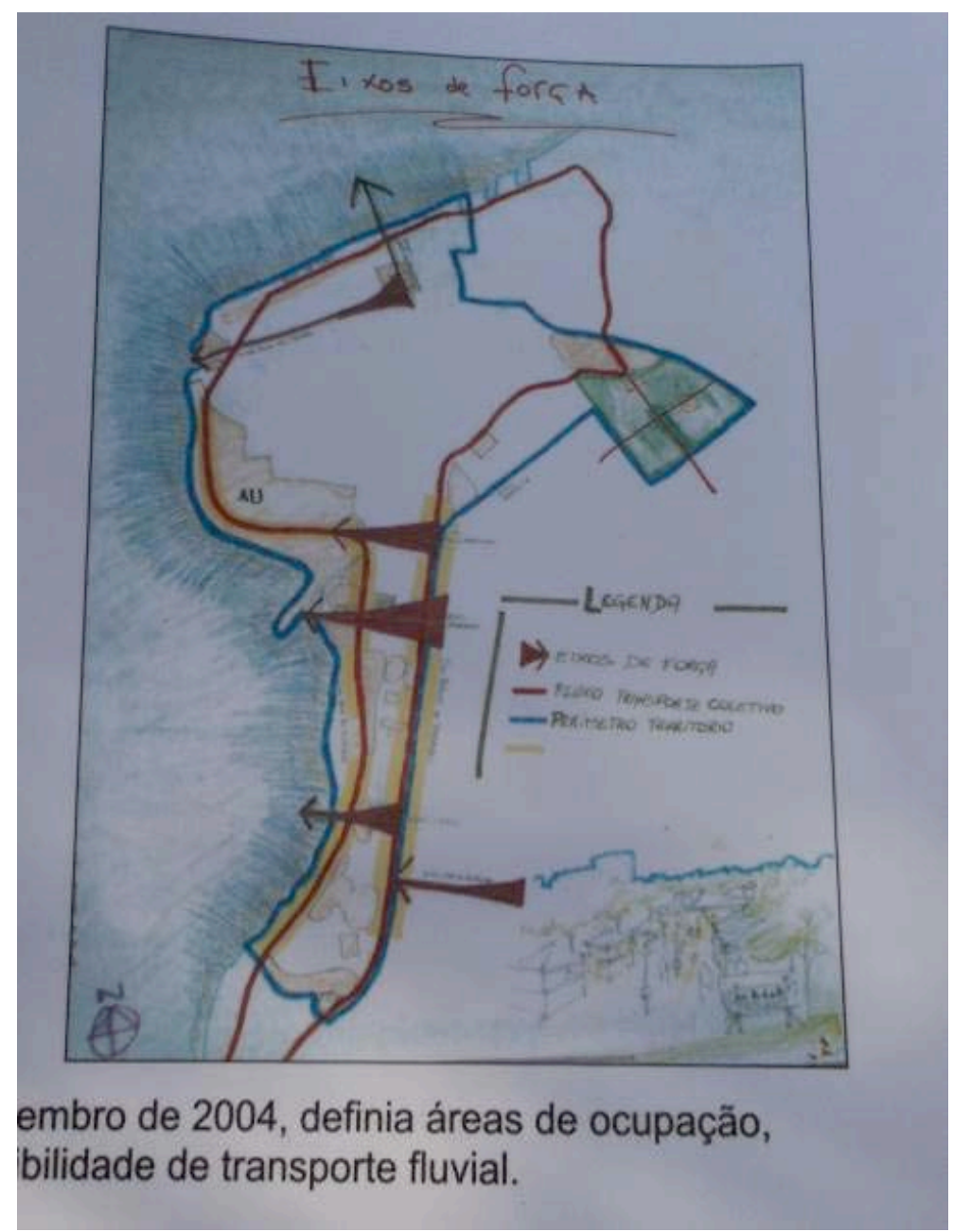

Figura 3.3

Mapa de planejamento do Território Social Mundial, perímetro do território, fluxos de transporte e eixos de força, 2004 (2012). A área em azul à esquerda do mapa representa o rio Guaíba, onde as setas indicam a possibilidade de pontos de acesso a transporte fluvial. Fonte: CasaTierra. 
A imagem de conjunto do quinto FSM sobre a foto aérea de Porto Alegre, instantâneo do momento em que ele foi ambiciosamente projetado sobre a cidade para nela recortar um território à sua imagem e semelhança, resiste melhor ao tempo do que o mosaico de pedra. Se não há declarações finais, a imagem dos temas e sub temas justapostos, do terreno loteado pela metodologia, sobrevive como um monumento. Os mapas esquemáticos de planejamento deste território expressam um impulso visual também operante no trabalho de metodologia: aquilo que De Certeau identifica como "o prazer de ver o todo", de dominar, de totalizar a desmesura da atividade humana (1980, p. 140).

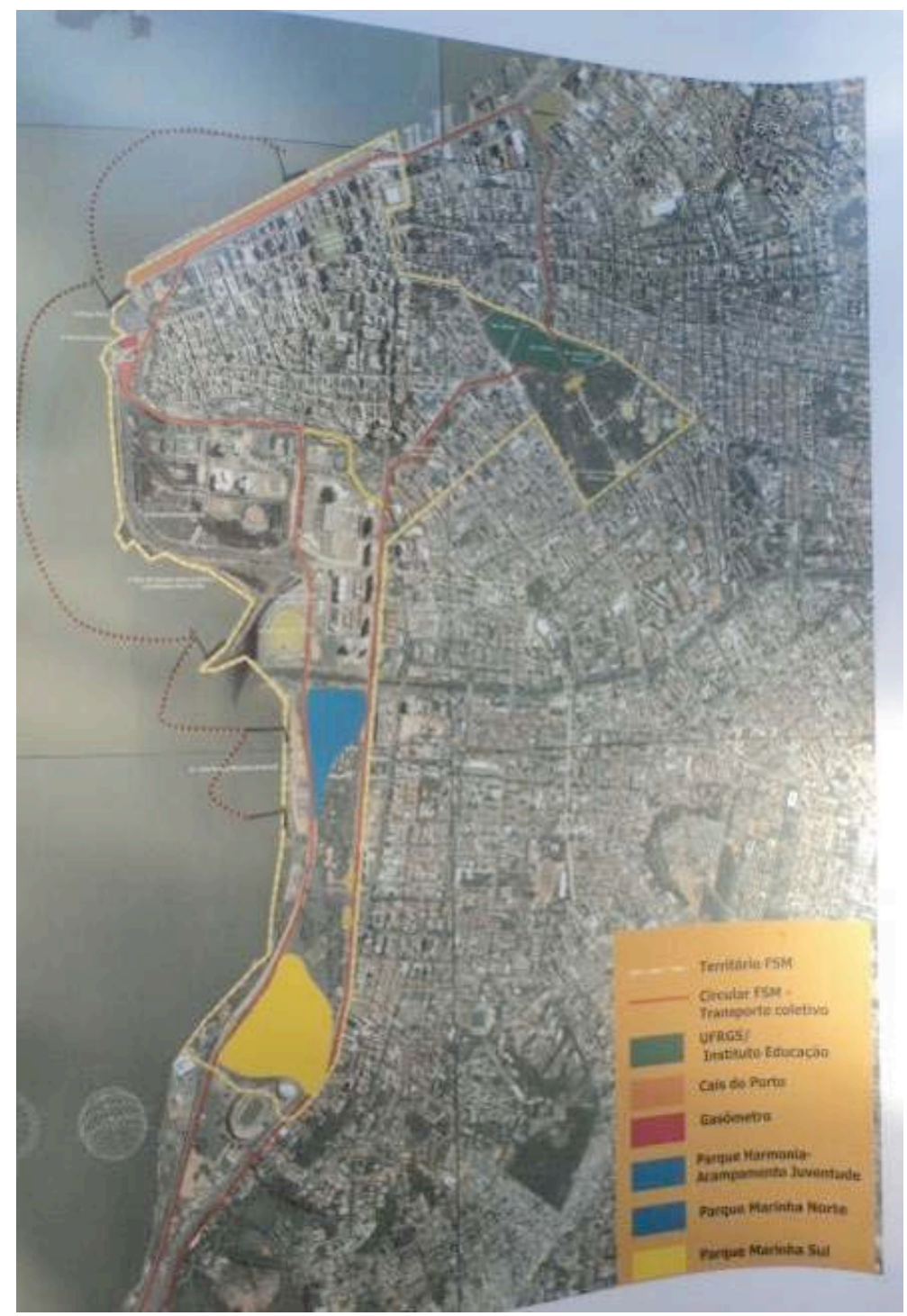

Figura 3.4

Mapa de planejamento do Território Social Mundial (FSM2005): estudo de circulação, 2004.

Fonte: CasaTierra, fotografia da autora. 
O olhar de cima implícito na disposição panorâmica da memória do FSM mimetiza o olhar da sistematização, que pretende tornar legível, como texto ou como mapa, a massa de interações e razões políticas dos encontros ${ }^{42}$ A figura do mosaico na memória do Fórum não é apenas uma ilustração: ela opera na produção dessa memória oferecendo-lhe uma forma, uma fórmula de legibilidade da experiência coletiva e um modelo de interação, legitimidade e pertencimento. $\mathrm{O}$ sentido de tabula rasa, que Boaventura de Souza Santos (2005, p. 89-90) emprega para descrever o Fórum Social Mundial, encontra sua ressonância na forma bidimensional do mural, do mapa esquemático de planejamento ou do mosaico. Não se trata no entanto de uma imagem descritiva, mas antes prescritiva, além de contraditória: a identificação do fórum à superfície plana - painel, planta ou tabuleiro - coincide com a produção da horizontalidade como critério da ação política, ao mesmo tempo em que define o olhar de cima como posição ideal de seu sujeito.

Nessa figuração espacial, o olhar estratégico próprio da cartografia e do planejamento urbano é condicionado. No contexto do Fórum, a visão de sobrevoo que o traçado metodológico proporciona é curiosamente atraída pela linguagem da horizontalidade, que corresponde por sua vez a expectativas particulares quanto à forma das relações políticas a serem estabelecidas entre participantes: trocas e diálogos livres sem uma direção pré-determinada; circulação de conhecimentos sem imposições de cima para baixo. A imagem da rede horizontal e uma série de categorias afins, que encontramos no vocabulário do FSM designando relações sociais e políticas, tais como auto-organização, não-linearidade e não-hierarquia, devem bastante de sua difusão ao mundo das redes, interações e interfaces digitais. Se seguimos observando as formas da memória do Fórum Social Mundial, veremos que o universo das tecnologias de comunicação e os modelos de interatividade concebidos no ciberespaço exercem sobre ele um apelo importante. A partir de aproximações entre as formas políticas encontradas no Fórum e as potencialidades destes modelos Arturo Escobar (2009) constrói uma análise em que o próprio FSM pode, em certa medida, ser entendido como resultado da dinâmica de "oportunidades sem precedentes para construir visões compartilhadas" que essas tecnologias possibilitaram, funcionando como um dos "nós chave" de um complexa estrutura que conecta em rede movimentos sociais e organizações locais de todo o planeta:

Seja como for, o fato é que o pensamento em rede chegou para ficar, pelo menos por um tempo, e oferece lições interessantes para re-pensar muitos aspectos da política de esquerda (talvez de qualquer política), das estruturas organizativas à dinâmica dos movimentos (Escobar, 2009, p. 396).

\footnotetext{
${ }^{42}$ Ainda em De Certeau: a posição elevada do observador construída pelos planos urbanísticos, transmuta o mundo que nos possuía em texto diante de nossos olhos, "Ela permite ler, ser um olho solar, um olhar de deus. Exaltação da pulsão escópica e gnóstica. Ser somente esse ponto que vê, essa é a ficção do saber” (De Certeau, 1980, p. 140).
} 
De fato, além de assumir a forma do painel, do mapa ou do mosaico, a memória imaginada como meio de conexão horizontal entre atores diversos, é associada também às figuras das redes de informação e comunicação virtuais. Uma memória “em rede" é concebida como interface de organização e interação, que facilite o desenvolvimento de um espaço compartilhado de trabalho e conhecimentos, ou, nas palavras de Escobar, um sistema em que múltiplos conhecimentos parciais possam contribuir para a emergência de uma forma de "macro-inteligência" (2009, p. 399). No mesmo sentido, o site Memória Viva, que chegou a oferecer para consulta as propostas encaminhadas ao Mural durante e depois do encerramento do FSM 2005, constituiria idealmente mais do que um mecanismo para tornar pública a pluralidade de ideias e planos formulados nos eventos. Após o breve período em que esteve disponível, não há registros públicos a respeito dos acessos nem sobre as interações que possa ter produzido, mas é interessante notar que esse banco virtual de informações foi imaginado sobretudo como uma tecnologia de conexão entre os participantes, um instrumento que deveria abrir a uma rede de colaborações o trabalho de aglutinação que até então havia sido uma prerrogativa dos organizadores.

Depois do Fórum de 2005, chegou-se a criar uma espécie de rede social: o Open FSM ${ }^{43}$, que deveria também permitir a interação permanente entre as entidades participantes e constituir um mecanismo para o desenvolvimento de projetos e campanhas, a articulação de parcerias e atividades conjuntas nos fóruns seguintes e até mesmo a convocação de ações.

\footnotetext{
${ }^{43}$ Ver http://openfsm.net.
} 


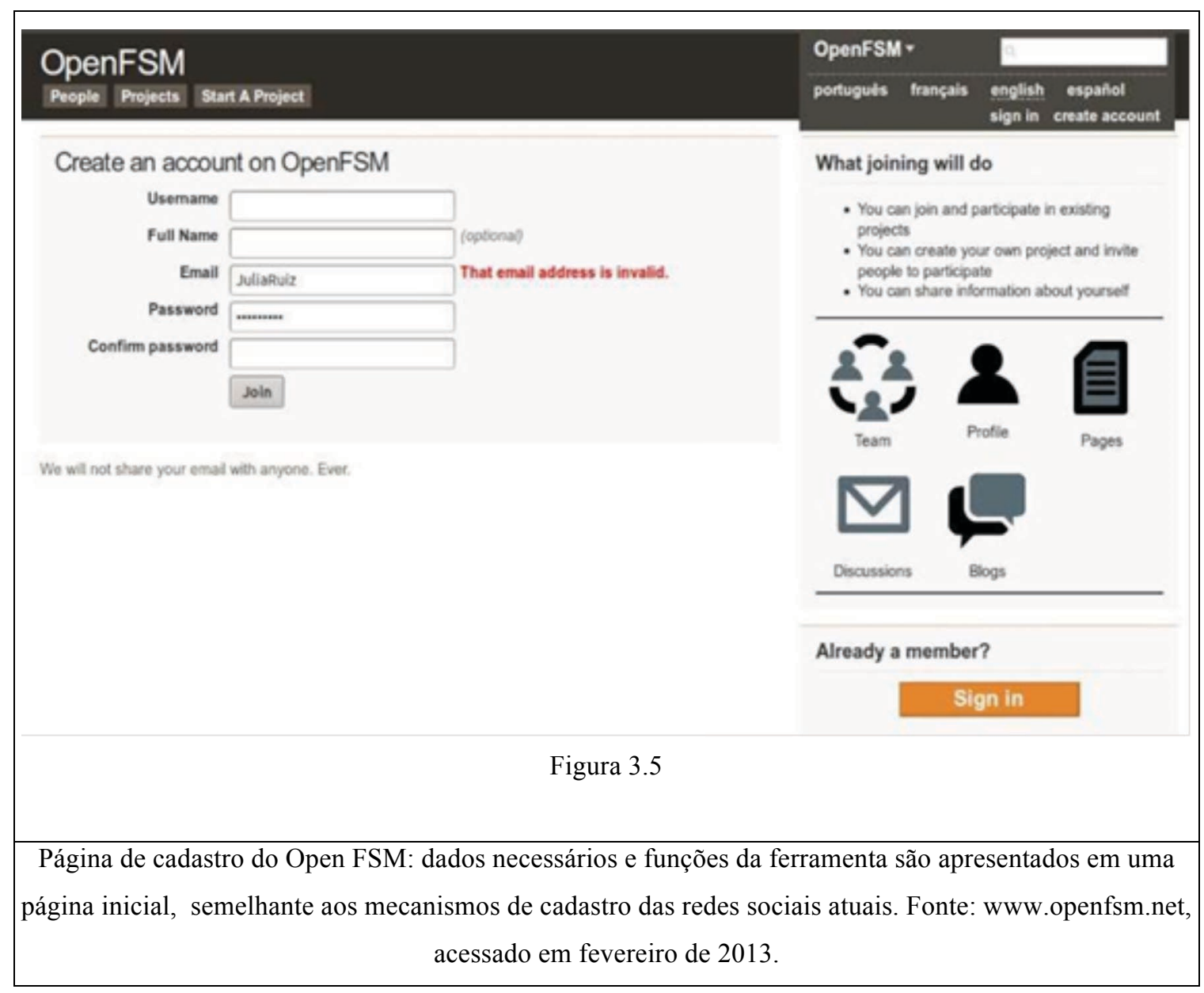

Criando um cadastro nessa rede, indivíduos e organizações podem conectar-se uns aos outros em torno de temas, projetos e tarefas organizativas particulares, compartilhar documentos e links ou enviar mensagens. Essa estrutura virtual parecia conferir operacionalidade a um processo "aberto", em que todas as contribuições precisam tornar-se públicas sem nunca colocar-se "em nome do FSM". O próprio processo Fórum tomaria assim a forma de uma rede virtual operando através de uma estrutura de coordenação (ou "facilitação") aparentemente sem peso, movida por interações espontâneas de parte usuários particulares (ou de grupos de usuários), graças aos recursos oferecidos por um software. Com pouca divulgação e adesão, a rede Open FSM permanece no ar até o presente. A iniciativa parece não ter tido muita repercussão, assim como no caso do Memória Viva, são raras as avaliações ou comentários disponíveis sobre o funcionamento dessa ferramenta e seu impacto no processo. Para Teivo Teivanem, o potencial democratizante da tecnologia é negligenciado nas instâncias organizativa e as ferramentas virtuais tendem a ser vistas como acessórias: 
É claro que muito do processo informal de tomada de decisão e planejamento estratégico do Fórum acontece por e-mail. Os organizadores no entanto tem sido relutantes em explorar maneiras pelas quais o ciberespaço poderia ter sido usado para organizar processos decisórios mais formais (Teivanem, 2003, p. 5).

Essas tecnologias são vistas como ferramentas que ampliam o sentido democrático, participativo do processo Fórum, possibilitando a interação "direta" entre pontos distantes do globo, potencialmente reduzindo os custos das colaborações transnacionais e assim tornando as decisões e reflexões coletivas mais acessíveis às organizações populares e grupos de base que não teriam acesso aos financiamentos com que contam ONGs e movimentos apoiados em estruturas burocráticas de maior porte. Na história do FSM, ao menos entre 2001 e 2005, o pouco desenvolvimento prático dos usos do ciberespaço contrasta com a importância do modelo relacional que ele representa - o espaço dialógico, decentralizado, em que todos os receptores são emissores em potencial (Escobar, 2009, p. 394). Independente de sucesso ou fracasso dessas iniciativas, a imagem cibernética como paradigma da criação de canais de relações políticas, assim como o mosaico, não deixa de exercer uma atração significativa sobre o discurso da metodologia do Fórum Social Mundial e sobre o que se entende por sua memória, mesmo anos antes da criação do Open FSM e da popularização do Orkut ou do Facebook.

A própria metodologia do FSM é idealmente concebida como um complexo de dispositivos virtuais capazes de facilitar, com a constância que os humanos invejam às máquinas, conexões mais claras entre interesses e maior estabilidade na articulação de projetos comuns, nas trocas de informações, cooperações e afinidades. Em 2005, como vimos, na medida em o próprio método torna-se um foco político central, a "arquitetura" do Fórum se aproxima de uma verdadeira engenharia, incluindo dispositivos de consulta, pré-inscrições, sub-eixos, auto-aglutinações, associados ao sistema também mais complexo de inscrições pela Internet: "Tudo começa no instante em que uma entidade preenche, via internet, o formulário de inscrição de uma atividade qualquer" (Porto Alegre 2005: um novo passo adiante, 2004). Esse imaginário de eficácia, interatividade e imediaticidade engloba também o sentido da memória. Ele está presente no artigo de Nicolas Haeringer que já comentamos, informando a noção de "restituição": para o autor, a tecnologia de comunicação e informação é uma ferramenta para que os conteúdos dos eventos Fórum possam ser re-investidos na continuidade do processo. Um sistema virtual de informação é a forma da memória na concepção de Haeringer, conectando a fase preparatória do Fórum à atividade futura de registro e sistematização: ela se realizaria como um "espaço de trabalho" contínuo on-line, onde inscrição, sistematização, arquivamento, preparação dos eventos convergem em um só gesto. 
Os (futuros) participantes serão convidados a dar a conhecer suas intenções, suas experiências ou suas proposições, e essas informações serão imediatamente postas no ar na Net; eles começam assim a construir a memória do Fórum por vir, enquanto tem a possibilidade de entrar em contato com participantes que não necessariamente conhecem, para preparar juntos um trabalho comum: a preparação do Fórum agora não está mais apenas nas mãos de seus organizadores (Haeringer, 2005, p. 66).

Nesta proposição que o autor considera fundamental na "integração do processo político", são inseparáveis, funções de uma só máquina virtual, a participação, mediada pela adesão à metodologia, e a produção da memória. Com auxílio da tecnologia, informações sobre as experiências dos participantes devem ser lançadas no futuro, "postas no ar" rapidamente, integrando-se à memória do processo de forma imediata. Se Fórum se define no presente como um espaço de diálogo e compartilhamento, aqui a memória também se espacializa: a rede permanente de relações virtuais prolonga essa forma do horizontal, integrando passado e futuro a uma mesma extensão onde todas as contribuições podem ser justapostas. Como propõe Haeringer, quanto mais "imediatamente" as intenções, experiências e proposições forem integradas a esse painel virtual, perene e ilimitado da memória, mais nos aproximamos da realização do "espaço aberto" de participação, socialização e experimentação prescrito pela Carta de Princípios.

Aqui, vemos que o nexo de integração política horizontal é carregado de uma ansiedade de memorização. Como na "ansiedade de historicização" que François Hartog associa a um regime de temporalidade contemporâneo, o presente do Fórum parece obrigado a "projetar-se a frente de si mesmo para tão logo ver-se como já passado" (2003, p. 217). Como instrumento da passagem do Fórum como evento ao Fórum como processo, a memória corrige a intermitência dos ciclos anuais. A identidade estabelecida no texto de Haeringer entre a memória do Fórum e um espaço de "trabalho comum" é digna de atenção: sugere que a memória pode ser instituída como um presente perpétuo do "espaço aberto", onde todas as intenções e proposições podem se dar simultaneamente.

As imagens do mural, do mosaico, do mapa e da rede virtual falam de uma memória do Fórum Social Mundial reduzida a uma função do método do "espaço aberto", em que a densidade da ações e expressões políticas aparecem apenas como expansão de um plano de relações horizontais. Nessa perspectiva, a memória é uma extensão no tempo dessa "plataforma" (outra expressão comum para designar a natureza do FSM) onde todos os discursos têm lugar para aparecer sem colidir uns com os outros e todas as formas políticas podem ser justapostas em um mesmo nível de (in)visibilidade. A memória, nesse sentido, mais do que reter o passado, parece querer preservar o presente contínuo que a metodologia do Fórum pretende instituir. $\mathrm{Na}$ temporalidade de um Fórum Social Mundial reduzido a seu método, a memória volta-se para dentro do processo que a produziu, buscando prevenir sua degradação no tempo, não se voltando para as 
qualidades exemplares do passado, mas tornando o presente do "espaço aberto" presente para si mesmo (Hartog, 2003, p. 138).

\section{A memória habitada}

Sabemos que a memória é povoada por circulações que se dão em muitos níveis, e além de sua superfície. Ainda que o plano da experiência política acomodado pela metodologia do Fórum pareça resistente a acidentes e distorções, como no "bloco mágico" de Freud $(1925)^{44}$, há planos subjacentes capazes de conservar traços duradouros, impertinentes às lógicas da sistematização e da restituição. Nessa perspectiva, a própria noção de horizontalidade, principal figura do pensamento que identifica o Fórum Social Mundial a seu método, pode mostrar-se mais instável do que sugerem as imagens do mural ou do mosaico. Se até aqui buscamos levar às últimas consequências as formulações encontradas no plano metodológico, a dimensão da memória nos obriga a considerar que a primazia da horizontalidade, embora possa ser entendida mais como princípio ou expectativa do que como uma realidade (Nunes, 2005a) ${ }^{45}$, encontra-se fortemente enraizada em experiências concretas, que extrapolam os conteúdos pertinentes a uma lógica de reprodução do Fórumenquanto-método.

Um modo distinto de pensar a horizontalidade no FSM encontra-se, por exemplo, no texto “The Ground Zero of the Forum", escrito por Steffen Böhm em 2005, após o último evento realizado em Porto Alegre, ao final do ciclo temporal que escolhemos focalizar nessa tese. O autor opta por construir sua análise a partir de uma rememoração pessoal que aproxima sua participação nos Fóruns Sociais à um experiência anterior no contexto do Neues Forum (Novo Fórum), processo de organização política do qual tomara parte no período de transformações da Alemanha Oriental, entre 1989 e 1990. É, antes de mais nada, um elemento afetivo, dificilmente descritível, que vincula complexidades políticas distantes no tempo e no espaço:

\footnotetext{
${ }^{44}$ No texto de 1925, Freud refere-se a um dispositivo de anotações comercializado como "bloco de notas mágico", para descrever relações entre o sistema da consciência que acolhe as percepções, podendo comportar-se como uma folha em branco diante de cada novo estímulo, e os sistemas mnemônicos adjacentes a ele. Consistindo em folha de filme translúcido sobreposta a uma superfície de cera, o bloco mágico fornece uma ilustração do próprio mecanismo da memória: embora, uma vez separada de sua base, a película não conserve traços duradouros, eles permanecem inscritos, gravados na cera subjacente (Freud, 1925, p.271).

${ }^{45}$ Segundo Rodrigo Nunes, "como um ideia reguladora kantiana, a horizontalidade paira acima das instanciações particulares das redes e espaços abertos que podemos experienciar, gozando do status ambíguo de ser tanto meio quanto fim" (Nunes, 2005a, p. 297).
} 
A esperança que eu tinha então não era que simplesmente nos precipitássemos na direção do ocidente e do capitalismo. Muitos esperavam outra coisa, um mundo diferente, e essa esperança produzia uma alegria que é difícil de descrever. Por muitos anos não senti de novo uma alegria como aquela, um tal senso de possibilidade - até que viajei até Florença para o primeiro Fórum Social Europeu em novembro de 2002. Então, sempre que eu penso sobre fóruns sociais, imediatamente me lembro da história do Novo Fórum e da minha própria história naquela época (Böhm, 2005, p. 136)

Em vez de justificar a existência do Fórum em si, interpretando-o segundo os critérios de sua própria lógica interna, o autor discute sua experiência à luz da lembrança de outra história pessoal e coletiva, em que espaços abertos de encontro e diálogo estão associados a vivências extraordinárias no campo da organização política. Desse ponto de vista afetivo, antes de definir-se como princípio metodológico ou inovação política, um "espaço aberto" é uma expressão de expectativas de renovação dos laços sociais ou da "esperança de um mundo diferente": "esse aspecto social do Fórum é importante, isso reduz a lógica tradicional da política a uma espécie de 'grau zero'. Traz todo mundo para um mesmo nível de ação" (Böhm, 2005, p. 138).

Esperança, expectativa, euforia e mesmo frustração fazem parte da formação do Fórum e dos engajamentos que se produziram em torno de eventos e processo, ainda que jamais tenham sido inscritas na programação ou consideradas conteúdo. A própria sensação de confusão que se tenta, em vão, combater no plano metodológico, segundo José Corrêa Leite (2003), não é menos importante:

Se o número colossal de atividades deixa uma sensação de fragmentação, uma certa imagem caótica, também rompe com a sensação de isolamento, infunde energias em seus participantes, emula e transmite confiança de que as alternativas ali apresentadas expressam os anseios de que outro mundo é possível por parcelas significativas da sociedade e por movimentos de todo o planeta. Este sentido de vivência é uma característica marcante de todos os grandes eventos do processo FSM para seus participantes (Leite, 2003, p. 123).

À luz do "sentido de vivência" que menciona Leite, é difícil conceber uma memória do Fórum Social Mundial que não seja interpelada por memórias de experiências individuais e coletivas anteriores. Ao mesmo tempo, esperança, alegria ou confiança, em seus sentidos fortes, não são passíveis de conservação como um conjunto de dados. Podem desaparecer por tantos anos, como sugere a história de Böhm, que se chega a acreditar que jamais tenham existido. No contexto da história do Fórum Social Mundial enquanto método, os caminhos percorridos pelos participantes podem parecer menos importantes do que o momento da convergência, em que experiências particulares incorporam-se ao processo apenas na medida em que são tornadas equivalentes umas às 
outras no plano metodológico. As singularidades do saberes e afetos são aspectos da experiência que permanecem vinculados ao caráter transitório dos fóruns-evento, dificilmente deixando-se inscrever em uma dinâmica de acumulação: essas "energias" caóticas dos encontros podem facilmente perder-se na passagem do evento ao processo, que, como vimos nos capítulos anteriores, exige uma série de sofisticadas operações intelectuais e burocráticas.

Embora, ao longo dos anos, a programação dos Fóruns tenha desenvolvido uma notável vocação enciclopédica, buscando abarcar uma diversidade cada vez mais ampla e um número cada vez maior de objetos, a sistematização é também, evidentemente, um procedimento de descarte, seja no processo de preparação dos eventos e estruturação dos eixos da programação, seja a posteriori como coleta e ordenamento de registros das atividades. No procedimento de redução da memória do Fórum a um movimento de restituição, que inclui apenas o que pode voltar-se "para dentro" do próprio FSM, impressões e emoções de difícil classificação, como as que destacam Böhm e Corrêa Leite, tendem a ser dispersadas como formas desprovidas de "conteúdos", relegadas ao campo dos relatos e lembranças de participantes. Elas também se conservam, sob a forma de imagens aparentemente acessórias, na linguagem depurada das análises e balanços: as espessuras da experiência individual eventualmente emergem nos textos como referências de relance ao ambiente de euforia geral, ao excesso de ruído, à concentração dos corpos nas salas, ao calor espantoso dos dias passados em Porto Alegre.

A própria cidade de Porto Alegre é um dos mais extensos e mais complexos suportes que guardam marcas, visíveis e invisíveis, destes aspectos pouco sistematizáveis da experiência do Fórum Social Mundial. Entre as marcas institucionais, destaca-se o Memorial do Fórum Social Mundial, inaugurado em 11 de setembro de 2001, data de lançamento do segundo FSM na cidade. Instalado em um edifício público, o antigo prédio dos Correios, localizado na Praça da Alfândega, centro de Porto Alegre, o Memorial foi concebido por iniciativa da Secretaria de Cultura, como parte do Memorial do Estado do RS. O projeto toma o Fórum como um capítulo importante da história da vida política da esquerda no Estado e uma expressão do caráter internacionalista do governo de Olívio Dutra (Partido dos Trabalhadores, 1999 - 2003), figura em torno da qual se expressam ao mesmo tempo expectativas de transformação social e um forte sentimento de firmeza moral gaúcha.

O Memorial do Fórum Social Mundial funciona por menos de dois anos, até que o Partido dos Trabalhadores perde as eleições estaduais em 2003 e as municipais em 2004. Em vista da chegada de novos administradores ao Memorial, o acervo, aparentemente não catalogado, que contava com documentos, fotografias e objetos, foi retirado de sua sede, devolvido aos doadores e parcialmente armazenado na Secretaria Executiva do FSM em São Paulo. Somente em 2011, um 
protocolo de intenções é assinado entre o Estado, a prefeitura e "entidades organizadoras do evento" para garantir um espaço permanente para arquivos de documentos do FSM no prédio da Praça da Alfândega (Franco, 2011). Apesar da institucionalidade, o memorial até o presente não se consolidou como um espaço de referência, os critérios de constituição do acervo não são claros, nem há mecanismos de consulta dos materiais. O espaço é utilizado de forma inconstante para eventos de organizações locais ou atividades vinculadas ao processo FSM que se realizam na cidade, mas não se tornou um lugar de visitação e não há indícios de que o lugar atualmente ofereça experiências ou objetos que produzam ressonância no presente (Carruthers, 2011).

Incluída no acervo atual está uma coleção de livros, documentos e folhetos, que começou a ser montada em 2001 e circulou desde então entre espaços públicos e privados da cidade. Inspirados pelo Mosaico de Pedra, no mesmo ano inicial do Fórum, um grupo de jornalistas propôs a formação de um Mosaico de Livros ou Biblioteca Social Mundial, a ser composta por livros e outros materiais informativos doados pelos participantes do Fórum. Já com um acervo reunido, inicialmente sem catalogação, o projeto perdeu rapidamente o apoio da prefeitura (que se limitava à disponibilidade da sala em que os materiais estavam armazenados) e mudou várias vezes de sede, eventualmente deixando partes pelo caminho, até ser parcialmente catalogado por volta de 2005 com apoio do programa de Pontos de Cultura do Governo Federal. 


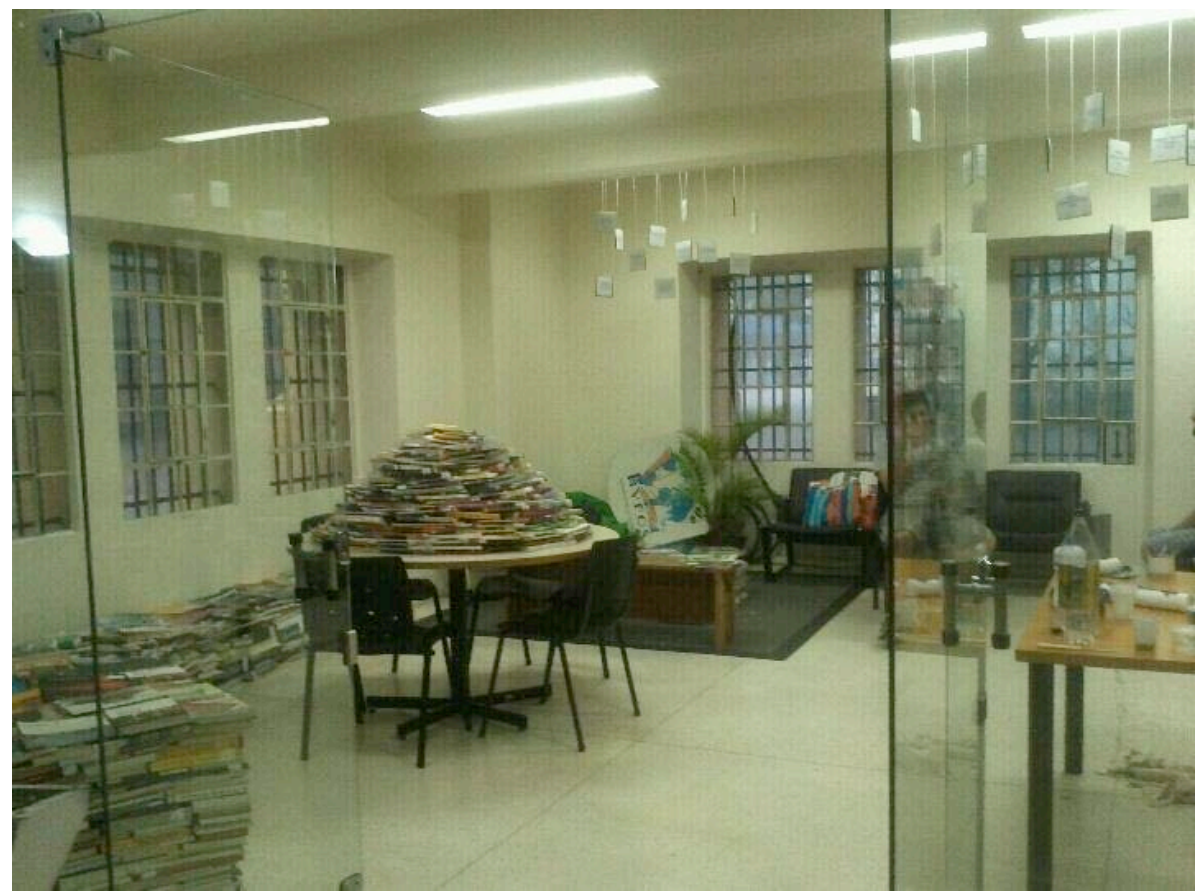

Figura 3.6

Exibição do acervo da Biblioteca Social Mundial no Memorial do Rio Grande do Sul, preparada por voluntários para a re-inauguração do Memorial FSM durante o Fórum Social Temático realizado em Porto Alegre, em janeiro de 2012. Nota-se que a disposição dos livros é antes uma demonstração de sua quantidade e variedade do que um tratamento sistemático do acervo para fins de consulta. Segundo Fernando P., voluntário, essa disposição também foi forçada por não haver no local estantes suficientes para a acomodação dos livros. As estantes que há na sala não aparecem na fotografia. Fonte: Fernando P. (2012). Foto: Rosana Vasques, disponível em: 


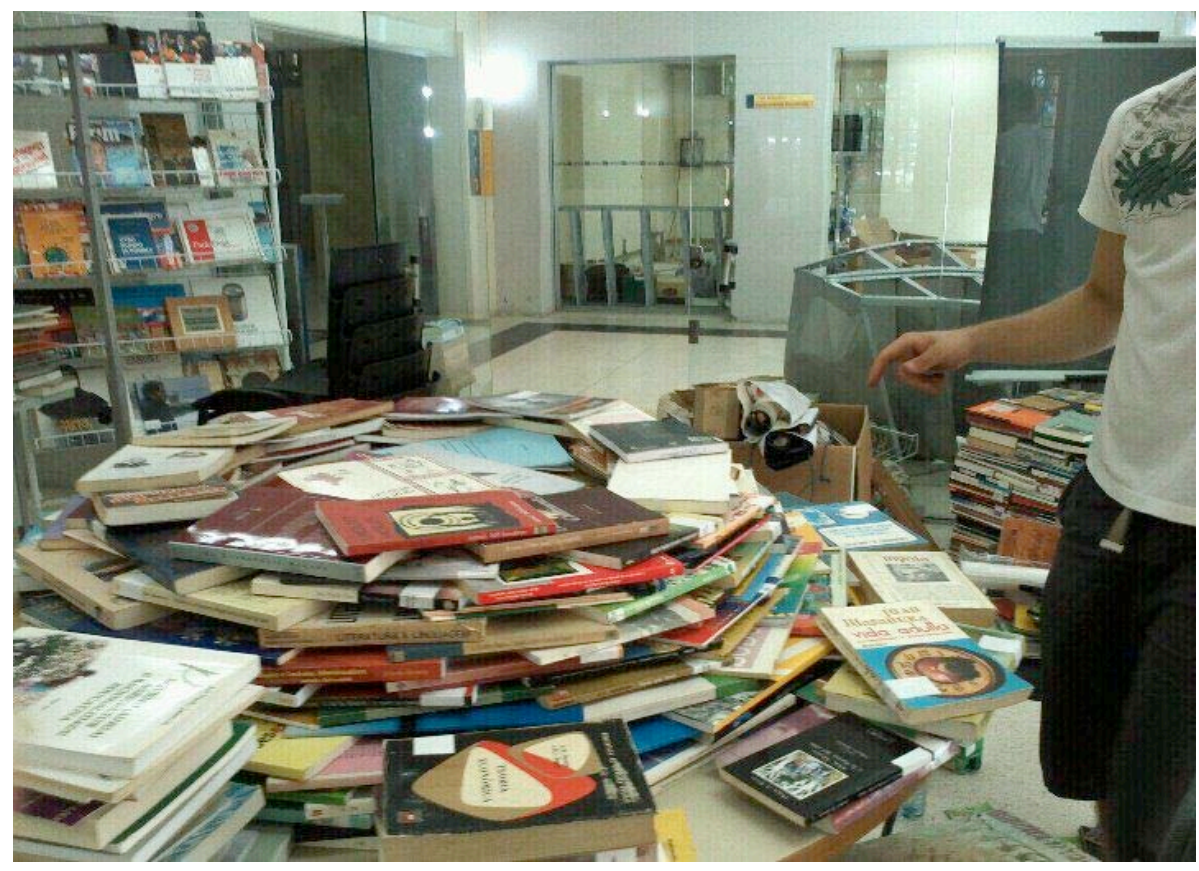

Figura 3.7

Exibição do acervo da Biblioteca Social Mundial no Memorial do Rio Grande do Sul, preparada para a o Fórum Social Temático realizado em Porto Alegre em janeiro de 2012. Fonte: site G1,

Embora informada pela imagem fixa do mosaico, a biblioteca escapou ao desaparecimento, mesmo sem localização física ou viabilidade de consulta, por que se manteve em movimento. Seus organizadores, independente da organização dos FSMs ou do apoio do Estado, continuaram obstinadamente a realizar a coleta de materiais, promovendo saraus e atividades de divulgação do projeto e do próprio Fórum Social Mundial e temas como o direito à comunicação e informação, diversidade sexual, combate ao racismo, em associação com organizações locais (informações obtidas em entrevista realizada com Ana Paula Stock, em 19 de abril de 2012).

Assim como a sobrevivência da biblioteca forçada pela precariedade de recursos materiais e graças à insistência de seus organizadores parece descolada do espaços e sistematicidade esperados em uma biblioteca convencional, muitas memórias do Fórum em Porto Alegre não dependem de suportes institucionais, e em muitos casos parecem mesmo resistir a enquadrar-se nas restrições impostas por catalogações e formalizações. Ao mesmo tempo em que o memorial permanece sem atividade e seu acervo ainda não é objeto de uma política de patrimônio, e ainda que nada impeça que isso aconteça no futuro, outros pontos da cidade exibem restos mais visíveis do FSM. 


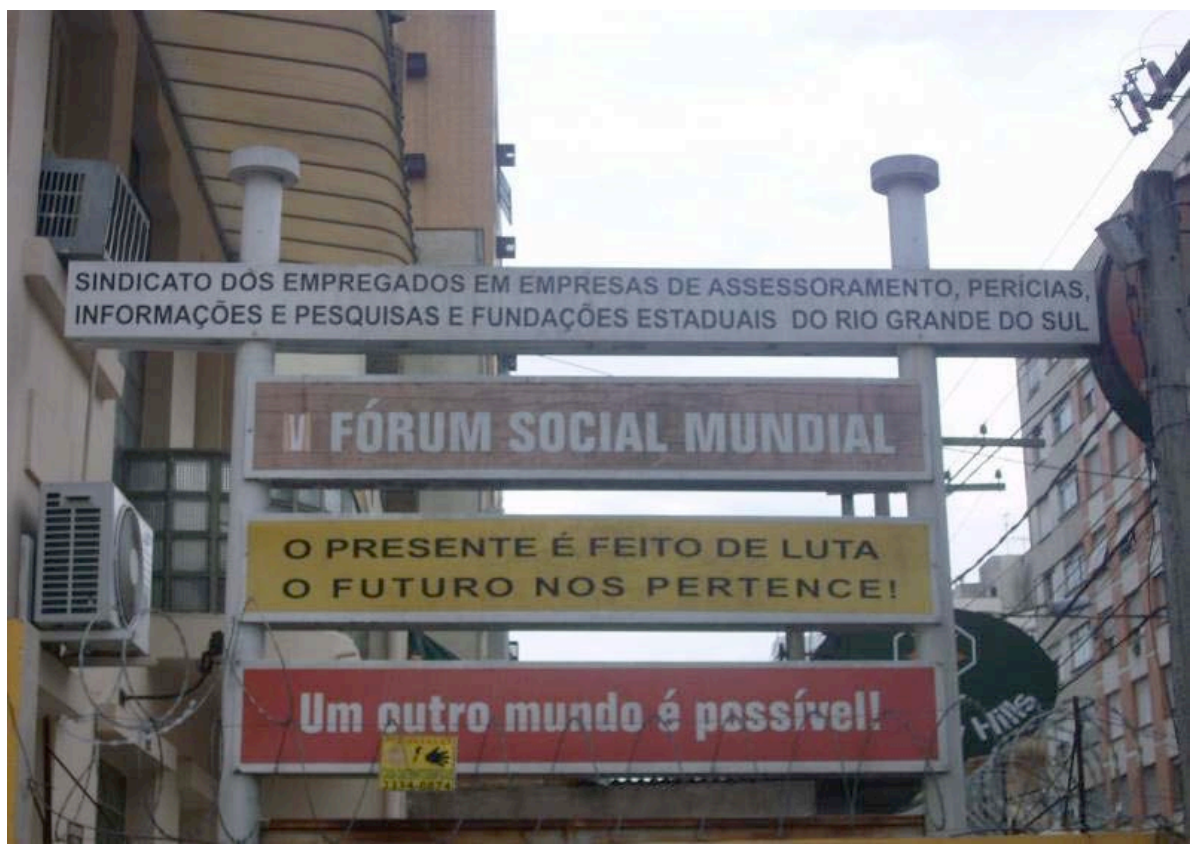

Figura 3.8

Rua Lima e Silva, Porto Alegre, Cidade Baixa, 2012. Letreiro com referências ao FSM 2005, em frente à sede de uma organização sindical estadual. Foto da autora.

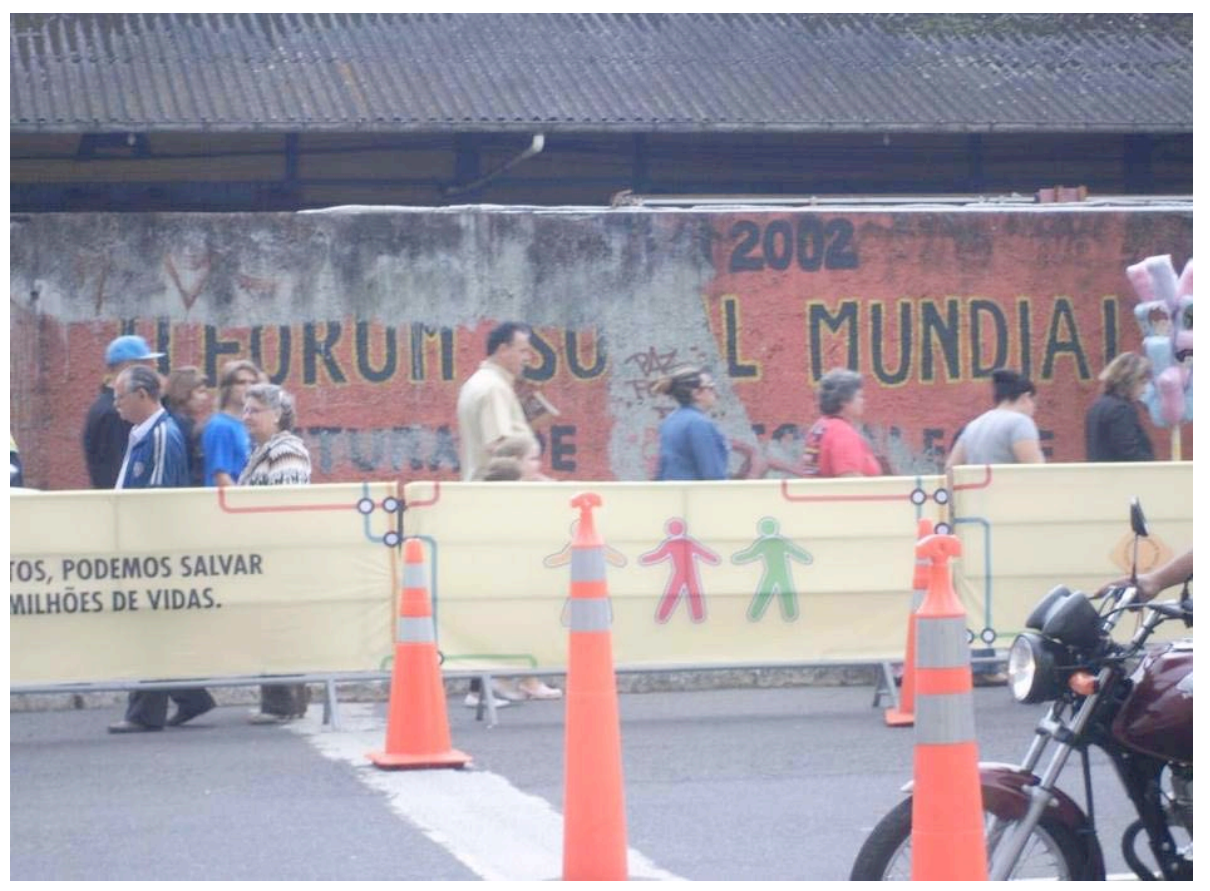

Figura 3.9

Muro da Avenida Mauá, 2012: o muro que separa a avenida da área dos armazéns do Cais do Porto deve ser demolido nos próximos anos em função de um projeto de requalificação, que prevê a instalação de um centro comercial, restaurantes e torres de negócios na área um dia ocupada por atividades do Fórum Social Mundial. 
Circulando pela região central em 2012, ainda é possível encontrar marcas dos eventos em espaços públicos ou privados. Quase apagadas ou descontextualizadas, essas marcas provocam lembranças e reatam associações entre pontos da cidade e as vivências dos dias em que dezenas de milhares de pessoas circulavam pela região com seus crachás e bolsas do Fórum à tiracolo. Como uma sinalização esmaecida de percursos políticos e afetivos produzidos durante os encontros, essas pistas materiais podem ser re-encontradas pelos passantes e produzir ressonâncias: elas criam na cidade lugares comuns onde memórias do Fórum podem ser geradas e compartilhadas. Como explica Mary Carruthers a respeito do Memorial do Vietnã em Washington, o muro marcado "não é ele próprio um contador de histórias, mas convida todos que o veem a contar histórias" sobre um conjunto particular de eventos (Carruthers, 2011, p. 71). Do ponto de vista de sua relação com Porto Alegre, ao largo da territorialização do método em 2005, a sequência de eventos anuais gerou lugares de memória, modos de circular pela cidade e de conhecê-la, uma "psico-geografia", tal como definida por Guy Debord, em que os comportamentos afetivos, relações e formas de ação individuais e coletivas se confundem com o planejamento (consciente ou não) do espaço (1955).

Retornando à cidade anos após a experiência dos Fóruns, posso confirmar que meu conhecimento da geografia de Porto Alegre é inteiramente condicionada pela experiência de participação no Fórum: a Praça Marechal Deodoro (que por muito tempo chamei de "Praça da Matriz”) é o marco zero, meu primeiro destino como voluntária em 2001, endereço da sede do Governo Estadual, da Câmara de Vereadores e do primeiro escritório do FSM na cidade. Descendo pela Rua Duque de Caxias chega-se à Usina do Gasômetro, sede de inúmeras reuniões, de escritórios da organização no FSM 2005 e ponto de saída do bloco da Marcha Mundial das Mulheres para a passeata de abertura do FSM 2003. Mas ainda resulta difícil descer a Duque sem ceder à tentação de, a certa altura, a dobrar à direita, tomar a Rua Riachuelo e encontrar quase casualmente a antiga Cabul, casarão hoje restaurado, então em ruínas, cedido pelo Instituto de Arquitetos do Brasil à organização do Acampamento da Juventude em 2002. 


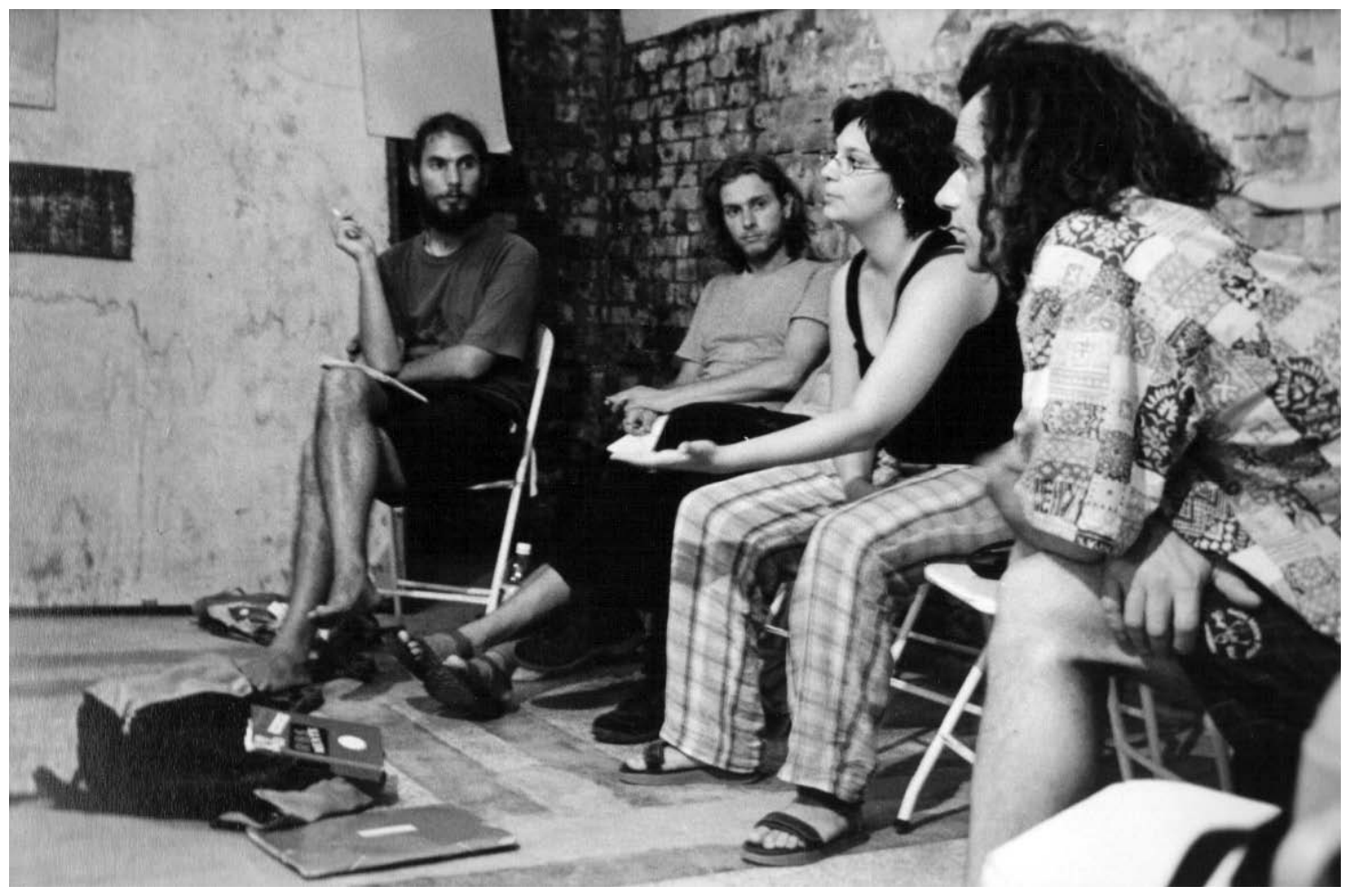

Figura 3.10

Reunião de preparação do II Acampamento, em janeiro de 2002, no Solar do Conde, edifício da metade do século XIX, sede do DOPS e do DOI-CODI nos anos 60 e 70. Em 2002, passando por obras de restauração para tornar-se sede do Instituto de Arquitetos do Brasil, o solar hospeda os trabalhos do Comitê Organizador do Acampamento da Juventude. O local ainda em ruínas, cujo acesso se dava por uma passagem entre tapumes na Rua Riachuelo, ganhou o apelido irônico de Cabul, por sua

"semelhança" com as imagens da cidade do Afeganistão que começara a ser bombardeada pelo exército estadunidense em outubro de 2001.

Foto: Andrea Lanzoni, 2002.

A história dessas caminhadas, assim como a história de uma manhã chuvosa no parque Harmonia que abre este capítulo, fazem parte do imenso conjunto de memórias dispersas, cujos temas não correspondem a nenhum eixo temático, que jamais estiveram vinculadas a nenhum mecanismo de inscrição nem acatam filiações institucionais de nenhum tipo. Associam-se antes a sensações de alegria, confiança, esperança ou frustração, que uma vez reencontradas no fundo das gavetas podem mostrar-se mais nítidas, mais resistentes aos choques do presente que as arquiteturas que buscaram circunscrever o conteúdo político do Fórum Social Mundial. Em busca de análises e balanços mais informais do que aqueles publicados no site do Fórum, as conversas que realizei com antigos participantes durante a pesquisa em São Paulo e Porto Alegre, trazem muitas vezes a surpresa de nos descobrirmos personagens de histórias esquecidas: minhas perguntas podem trazer à tona episódios que há anos não eram narrados e, ao mesmo tempo, perco a conta de quantas vezes 
uma interpelação em uma conversa me faz lembrar momentos da experiência já apagados das histórias que eu mesma seria capaz de contar.

A memória voluntária de que fazem parte as análises e balanços escritos, os documentos de metodologia ou a coleção de boletins informativos disponíveis no site do FSM, é sempre um pouco enfadonha. Como no comentário de De Certeau sobre a vasta produção textual que seguiu os eventos de Maio de 1968 na França, "Certamente qualquer pessoa normal se irritaria no final, pela incansável repetição dos mesmos títulos, das mesmas fotos, dos mesmos slogans ou dos mesmo panfletos, em resumo, pela tautologia dessa retórica crescente" (1968, p. 106). Os registros do FSM que seguem até hoje proliferando na Internet são um conjunto em grande medida redundante, remetendo sempre às mesmas fórmulas. Já essa memória informal, compartilhada em confiança, embora possa servir-se das mesmas fórmulas, tende a desviar-se dos assuntos principais estabelecidos pelo material escrito. Os encontros com companheiros dos primeiros anos do fórum são longas sessões de rememoração, em que a reflexão sobre a qualidade política dos acontecimentos passados dá-se fundamentalmente como exercício narrativo em que trocamos imagens, formulações e sensações. Nessas conversas, a conexão entre o sentido político da experiência do FSM para seus participantes e o conteúdo afetivo da mesma experiência é evidente e incontornável. Alheias a cartas de princípios, as histórias contadas não tomam o Fórum enquanto método, mas quase sempre como um momento de grandes conflitos e acidentes que apenas o distanciamento temporal permite tratar sem sobressaltos.

O acesso a essa outra forma de memória do Fórum também se articula nas conversas em torno de alguns marcos e lugares. O Conselho Internacional, o escritório de São Paulo, a PUCRS, a marcha de abertura, mais do que fatos ou espaços concretos, tornam-se posições de rememoração, assumindo a qualidade de lugares mentais que, quando encontrados, assim como as marcas materiais na cidade, nos convidam a contar histórias. Essas localizações, são o que Mary Carruthers chama de um "lugares mnemônicos": não simplesmente objetos, mas esquemas cognitivos comuns, que estabelecem contiguidades (mesmo que inventadas) e situam os exercícios de rememoração (Carruthers, 2011, p. 39). Neste sentido - como contexto de experiências que compartilho com a maior parte dos entrevistados em Porto Alegre, nosso espaço comum - o Acampamento da Juventude é uma posição fundamental para a observação de formas da memória que a retórica tautológica do "método Fórum" silencia. O Acampamento torna-se um "lugar" de rememoração, onde a experiência do FSM permaneceu, em certa medida, "impensada", como propõe Rodrigo Nunes: “presente, mas não visível ou articulável” (2005, p.294), estranha à ordem metodológica e inacessível aos procedimentos de sistematização. 
As histórias do Acampamento da Juventude, de que participei mais ativamente em 2002, não contam com nenhum memorial, mas cumprem na memória informal e indisciplinada de minha própria experiência um papel crucial, que conduz às margens do processo FSM e proporciona sobre ele um ponto de vista particular. No vocabulário do Comitê Organizador Brasileiro e do Conselho Internacional do Fórum, segundo Nunes, o termo "juventude" está imediatamente associado a algo de menor importância e a dimensão política do acampamento tende a ser negligenciada pelas instâncias organizativas: “ainda em 2004, antes do Fórum na Índia, um dos principais atores do COB/Secretariado Executivo ${ }^{46}$ ainda se perguntava 'o que nós vamos fazer para incluir a juventude?", aparentemente ignorando a existência do acampamento e "o fato de a 'juventude' ser grande o suficiente para ocupar seu próprio espaço sem precisar ser reconhecida por alguém (Nunes, 2005, p. 295)",47.

A “juventude” estava lá, mas não parecia estar "incluída” no processo. Segundo a análise da antropóloga Michal Osterweil, "Embora muitos participantes talvez não tenham percebido [...] o Acampamento da Juventude era verdadeiramente um mundo dentro do Fórum” (Osterweil, 2005, p. 147). Embora após o evento de 2002 o Conselho Internacional manifeste o reconhecimento do Acampamento como parte integral do Fórum (Nunes, 2005, p. 288), em nenhum momento os dois se confundem inteiramente e pode-se afirmar que relação do Acampamento com as instâncias organizativas do FSM era de tensão contínua. A presença dos membros do Comitê Organizador do Acampamento nas reuniões de preparação dos Fóruns, segundo uma das integrantes, entrevistada em Porto Alegre em 2012, era um "perigo": "tinha uma regra do jogo estabelecida, e a gente estava fora, a gente não jogava dentro das regras". Contestando publicamente a efetividade do discurso horizontalista do Fórum, em entrevistas e materiais de difusão de suas atividades, a força "sem direção" do Acampamento, "era um perigo porque a gente estava dizendo várias verdades que todo mundo sabia e ninguém podia falar, porque todo mundo era muito diplomático e estava ali fazendo política, nas suas relações de respeito". Pouco interessados na diplomacia do método Fórum, os “jovens" responsáveis pela infra-estrutura de hospedagem de boa parte do público dos eventos (e cientes da importância de seu trabalho para o sucesso dos eventos), sentiam-se parte de uma geração política que ainda realizava protestos na Europa e Estados Unidos com base em princípios de tomada de decisão e "faça-você-mesmo" que as ONGs, movimentos e organizações que

\footnotetext{
${ }^{46} \mathrm{O}$ autor refere-se, em nota de rodapé, ao artigo "Olhar atento sobre o Fórum" (Gribowsky, 2004).

${ }^{47}$ Esse ponto de vista é reforçado, por exemplo, na fala de Thomas Ponniah, recolhida em 2005 durante o debate sobre o futuro do Fórum: "quando você vai a um protesto contra a Organização Mundial do Comércio ou contra a guerra, é marcante como metade dos manifestantes são pessoas jovens, frequentemente são jovens que estão na frente e são as primeiras a ser atingidas por gás lacrimogêneo... agora, quando se fala de um painel ou oficina ou seminário no Fórum Social Mundial, a metade dos painelistas não é de pessoas jovens; isso é um problema sério. Não é um problema de identidade, é um problema político: não estamos incorporando as pessoas jovens e a nova política que eles corporificam ao processo Fórum Social Mundial" (Intergalactika, 2005, p. 146).
} 
compunham a coordenação do FSM tratavam com interesse, mas jamais tenderam a incorporar na prática.

O Acampamento engajava diretamente, na politização das tarefas organizativas e ordinárias, uma energia que a estrutura burocrática do Fórum Social Mundial inibia. Enquanto a vasta maioria das atividades inscritas na programação dependiam de grades horárias, disponibilidade de salas e da presença de convidados e facilitadores para acontecer, no Parque Harmonia instalava-se a céu aberto uma efervescência cultural e política contínua: dias e noites de atividades - de plenárias nacionais do movimento estudantil a oficinas improvisadas de meditação - tão intensas quando desregradas (Osterweil, 2005). Nas palavras da organizadora entrevistada, este caráter aberto "na prática" do acampamento era o que "juntava uma gurizada dos diabos": "A pessoa vinha para o Fórum, chegava e ia para a PUCRS [...] as coisas tinham sido desmarcadas, os horários estavam errados, as pessoas não tinham chegado para a conferência - todo mundo perdido. Daí vinha para o acampamento: aí via de tudo!"

Segundo Nunes (2005), "para quem estivesse prestando atenção”, o Acampamento correspondia à "primeira vez que a conexão histórica entre [os protestos de] Seattle e o FSM estava sendo explicitada internamente". Algumas atividades realizadas no Acampamento com a participação de ativistas, muitas vezes estrangeiros à rede de relações do Conselho Internacional, provocavam apreensão: protestos e ações diretas realizadas durante os eventos do Fórum, quase invariavelmente partiam do Acampamento ou passavam por ele. Dali também saía boa parte das imagens do Fórum que terminavam estampando as primeiras páginas dos jornais: "para a mídia que só conseguia ver exotismo naquilo que estava acontecendo, o que poderia ser melhor do que milhares de jovens com suas caras frescas, piercings, tatuagens e dread-locks morando em barracas" (Nunes, 2005, p. 286)?

Resultantes da realização de quatro edições do Acampamento, há pilhas de documentos guardadas, discos de computador cheios de fotografias, milhares de e-mails, registros de reunião e debates de vários tipos. No porão de outro casarão antigo no centro de Porto Alegre, o coletivo CasaTierra, formado por algumas das pessoas que mais ativamente participaram da construção das cidades temporárias no Parque Harmonia, guarda muitas dessas memórias, misturadas aos projetos atuais de bio-construção e intervenções urbanas que realizam hoje em dia. Estes materiais nunca foram submetidos a nenhuma sistematização ou tratados com alguma pretensão formal de arquivamento: estão simplesmente lá, sem que ninguém jamais cogite livrar-se deles. 


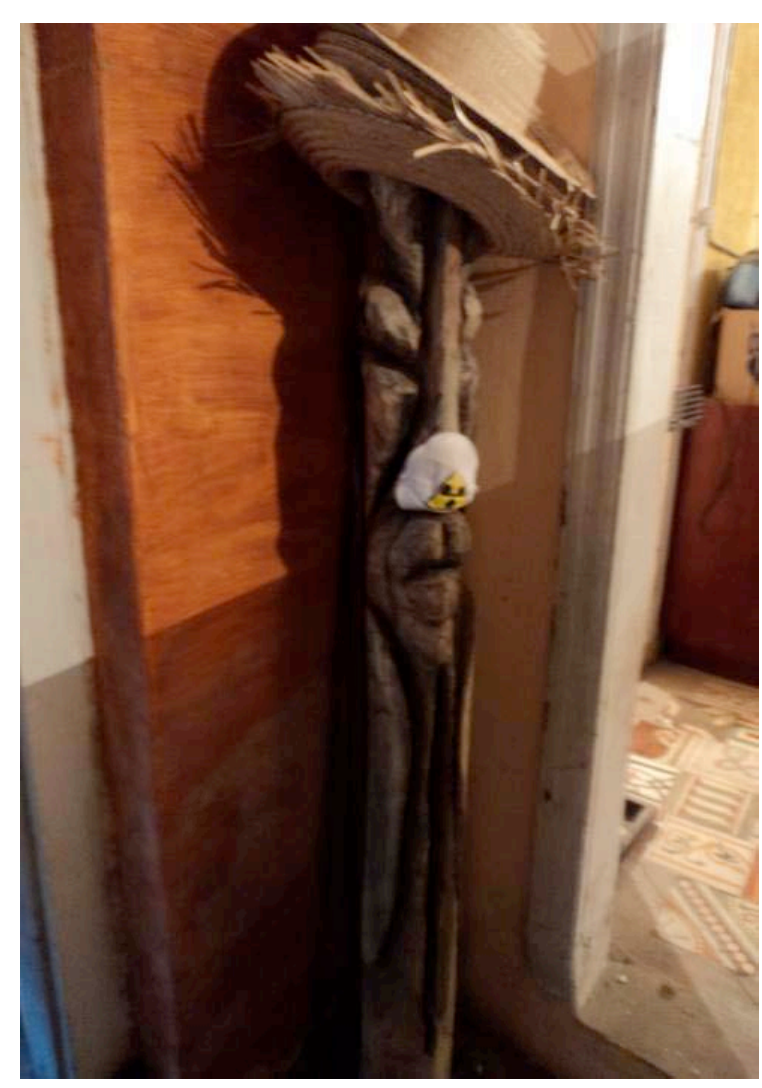

Figura 3.11

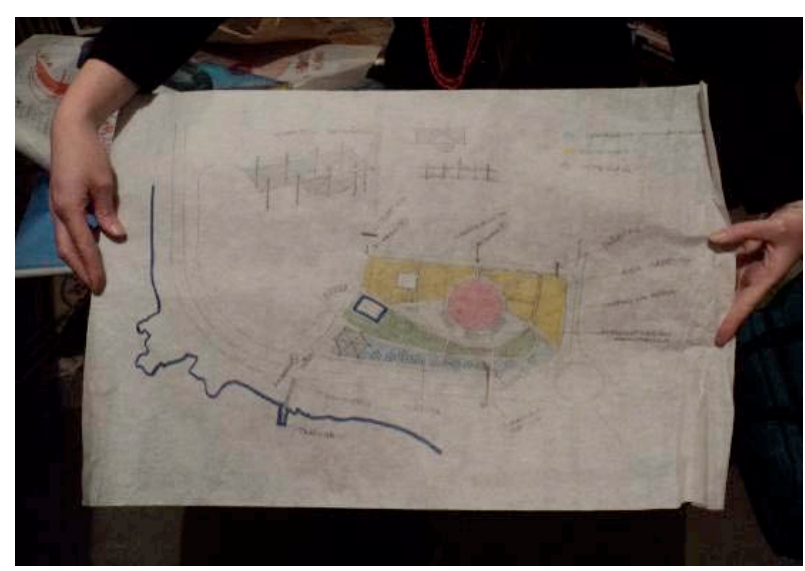

Figura 3.12

Planejamento do I Acampamento Intercontinental da Juventude, 2000 (?) (2012).

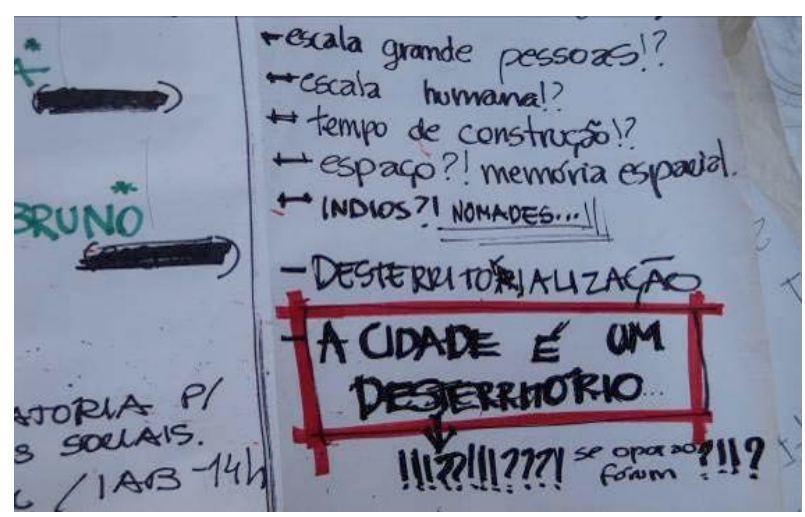

Figura 3.13

Escultura-monumento em homenagem ao ativista italiano Carlo Giuliani, realizada no Acampamento da Juventude Notas de reunião do Comitê Organizador do Acampamento da Juventude em 2004/2005 (2012).

durante o FSM 2002. "Disfarçada" com chapéus e máscara, no Atelier CasaTierra (2012) .

Talvez um pouco como os livros da biblioteca errante, parecem-se mais com os objetos ditos "de valor afetivo" que guardamos desordenadamente em casa com parcelas iguais de apego e descuido. Rolos de papéis, cartazes, panfletos, adesivos colados nas garrafas térmicas de mate, documentos, uma ou outra maquetes e objetos estranhos como o tronco esculpido que em 2002 serviu de monumento à memória do jovem Carlo Giuliani, morto pela polícia durante protestos contra o G8 em Gênova (Di Giovanni, 2012). Estes objetos, em vez de formar parte de um acervo isolado das contaminações do presente, habitam o espaço de trabalho e convivência deste grupo, prestando companhia silenciosa a suas discussões e novos planos.

O CasaTierra é ao mesmo tempo um grupo e um lugar - na memória e na cidade constituído por laços políticos e afetivos que se criaram durante os anos da realização do Fórum Social Mundial, na experiência compartilhada de organização dos Acampamentos Intercontinentais 
da Juventude. É quase impossível falar de suas atividades de hoje sem fazer referência aos acontecimentos do Fórum e do Acampamento. Durante uma visita ao porão-atelier, ao falar sobre esta história, os integrantes afirmam: “a gente não tem dúvida de que a gente é o que se formou nesse período". A sala em que os encontro para conversas e entrevistas é povoada por objetos acumulados desde 2001. Mesmo que não estejam legíveis o suficiente para constituir uma documentação deste processo de formação, os objetos estão certamente vivos na conversa, no ambiente, na aparência amontoada, cantos e prateleiras ou no cheiro familiar de coisas guardadas: "você sabe" - me diz uma moça vinda do interior do estado em 2000, ex-militante do PT e que hoje estuda antropologia - "as relações humanas são importantes nesse processo, lá pelas tantas virou um modo de vida". Neste caso, objetos e lembranças formam uma memória que não se distingue de um "modo de vida" e dos modos de fazer política que o coletivo desenvolve anos depois. Neste espaço, onde não parece haver nenhuma expectativa de patrimônio ou arquivamento, sem método ou sistematização, a memória do Fórum Social Mundial enquanto uma das experiências políticas mais complexas deste começo de século, parece-me mais plena do que em qualquer outro ponto da cidade $^{48}$.

É um local de trabalho, marcado pelo espírito faça-você-mesmo de seus ocupantes, da decoração até as instalações elétricas e hidráulicas. É um local também bastante úmido. Em um primeiro momento, ao notar que alguns documentos que habitam o porão estão se apagando por falta de condições de conservação, o pesquisador pode ter a impressão de estar diante de uma irremediável perda em processo e indagar porque tanta gente se esqueceu de preservar esses vestígios. A mesma reação não seria estranha com relação ao desaparecimento do Mosaico de Pedra, o cancelamento do site Memória Viva, a dispersão dos materiais reunidos no Memorial do Fórum em sua primeira fundação ou a precariedade da Biblioteca Social Mundial. Entretanto, me arrisco a pensar que essa dispersão ou esquecimento não são puramente negativos. Aqui, onde objetos que poderiam ser tomados como emblemas do Fórum são tratados com displicência, é que se abre espaço para outras qualidades da memória e a dimensão das alegrias e frustrações compartilhadas torna-se mais importante que a integridade dos símbolos, ou do que qualquer "marca" do FSM.

Primeiro destes símbolos, quase uma marca registrada, o slogan "Um Outro Mundo é Possível", foi desde seu surgimento objeto de desvios, distorções e outros sacrilégios. "Um Outro

\footnotetext{
${ }^{48}$ Fico sabendo, que essa forma habitável da memória pode ser encontrada também em outros espaços de Porto Alegre, fundida às histórias e práticas de outros coletivos: em seus encontros com outros grupos politicamente ativos na cidade, os antigos organizadores do Acampamento continuam descobrindo histórias que não conheciam sobre suas próprias experiências políticas, encontrando outros sujeitos dizendo que, como eles, são aquilo que "se formaram" no período em que o Fóruns Sociais aconteceram na cidade.
} 
Mundo é Possível?"; "Um outro mundo é necessário"; "Um mundo socialista é possível”; "Outra educação é possível”; “outro banheiro, é possível?”; “outro mundo já foi bem melhor”, são poucos exemplos entre centenas de usos profanos. Também o título "social mundial” jamais esteve a salvo de apropriações cotidianas pouco cerimoniosas: a frequência com que os encontros entre participantes resultavam em casos amorosos é lembrada como "Fórum Sexual Mundial", e muitos dos passaram pelos eventos em Porto Alegre entre 2001 e 2005 terão partilhado "baseados sociais mundiais". Estes usos deslocados são como atos-falhos voluntários: trazendo à tona conteúdos suprimidos do discurso mais estritamente "político" que produz o Fórum Social Mundial como totalidade coerente.

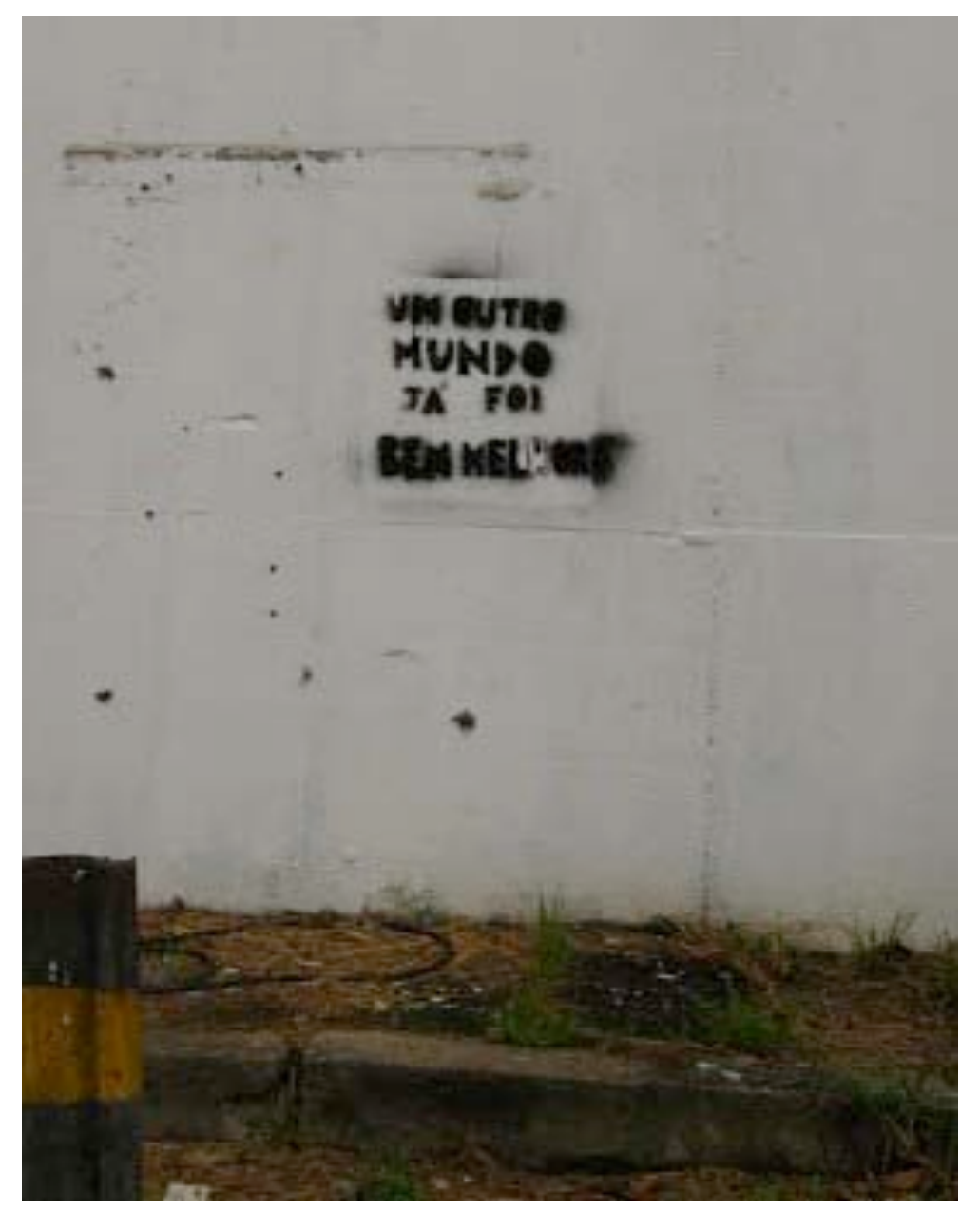

Figura 3.14

Grafite: "um outro mundo já foi bem melhor", durante a realização do Fórum Social Temático: 10 anos do Fórum Social Mundial, em 2011.

Fonte: CasaTierra

O Fórum e sua memória vivem também de contaminações e agravos, como atestam as inúmeras paródias de sua única palavra de ordem. Michael Taussig (1999) chama atenção para o aspecto positivo desse tipo de gesto iconoclasta, não de destruição completa, mas de desfiguração: 
trata-se de arranhar a superfície de um símbolo. Como pixar uma bandeira ou quebrar o nariz de uma estátua, as paráfrases e paródias do lema do Fórum ferem sua integridade mais superficial apenas para mostrar o potencial subversivo de suas outras existências, de suas margens ou de seu enraizamento na dimensão mais ordinária dos processos de organização política.

É precisamente aqui, no centro nervoso desse esquecimento ativo, com suas queimaduras, suas marcas selvagens, seus cortes cruéis e muitas vezes engenhosos... que a desfiguração exerce sua curiosa propriedade de ampliar, não destruir, valorizar, extraindo o sagrado do mundano e habitual (Taussig, 1999, p. 54).

Ao contrário do simples apagamento, a dispersão ativa da memória do Fórum Social Mundial não destrói o monumento da sua estrutura metodológica, mas expõe sua superficialidade. Sob a forma da displicência ou do deboche, a memória descuidada de acontecimentos corriqueiros, conversas, pequenas decisões, improvisos, reuniões cansativas ou brigas, lembra que um "espaço aberto" não é um fato, "mas um artefato" (Taussig, 1999).

A ambivalência ou contradição do Fórum Social Mundial como espaço político, como sugere Steffen Böhm, está ligada ao ocultamento ou inconsciência das formas da sua produção como artefato político:

Há uma certa negação do poder trabalhando dos dois lados: de um lado, os organizadores não veem ou não confessam a importância política de seu próprio trabalho; de outro lado, não há nenhum grande esforço de parte da multidão de participantes para responsabilizar os organizadores por suas decisões $(2005$, p. 144).

Embora encontremos no artigo do autor uso de noções semelhantes às empregadas nas defesas da metodologia do FSM como espinha dorsal do "espírito de Porto Alegre", o caminho da reflexão de Böhm, aderindo à densidade de sua própria memória, o leva a questionar a suposta horizontalidade dessa metodologia e traz de novo à tona questões sobre estratégia e poder:

o mantra do espaço aberto dá a impressão ou mesmo a ilusão de que o fórum social seja um espaço completamente horizontal. O que não se percebe com frequência é que, no entanto, todo espaço aberto precisa ser aberto por alguém; e nesse sentido, todo espaço aberto é de antemão fechado (Böhm, 2005, p. 139).

Na percepção de Böhm, há algo faltando na horizontalidade da metodologia do Fórum: “o grau zero da política não tem a ver só com socializar e falar", mas precisamente com o engajamento nas escolhas pragmáticas implicadas produção do espaço aberto: “mesmo na menor das decisões tomada com relação a onde o Fórum vai acontecer, como o dinheiro será levantado, onde o dinheiro 
será gasto, é no final uma decisão política, é uma questão de poder" (Caracol Intergalactika, 2005, p. 162). Nessa perspectiva, diametralmente oposta àquela contida na Carta de Princípios, que define o Fórum como espaço onde não há poder, o grau zero da política é a experiência "comunal e corporal" de imersão nas questões do poder, onde originam o prazer e a esperança pelas quais experiências políticas tornam-se humanamente inesquecíveis e historicamente irreversíveis (Böhm, 2005, p. 136).

Podemos entender, como sugere Carruthers, que a permanência no tempo destas experiências extraordinárias não é constituída por objetos, mas por posições: "uma questão de lugares duradouros, não de conteúdos" (Carruthers, 2011, p. 73). Estes lugares “mnemônicos”, são também lugares de saber e poder compartilhados, misturados aos modos de vida e relações afetivas. Não perdemos de vista o "velho" problema da estratégia discutido no primeiro capítulo: é possível entender que próprio sentido desta dimensão afetiva das práticas políticas que Böhm chama de "horizontais" está vinculado ao exercício de constituição de lugares (comuns) de poder. Não por acaso, o local da reflexão um tanto drástica sobre os destinos do Fórum com que abrimos este capítulo foi um ponto provisório do Parque Harmonia: naquele instante, na nossa barraca de camping, outro mundo e outro Fórum eram perfeitamente possíveis. A reflexão a respeito da memória - o que conservar, o que destruir, o que reconstruir - ao contrário do que prescreve a imagem da superfície horizontal, não é metodológica, mas estratégica, feita a partir de um lugar de poder: na experiência de engajamento pleno, corporal e afetivo com o poder, com as tomadas de decisão e suas consequências, inseparável da sensação genuína de que tudo pode ser destruído e reconstruído quantas vezes se julgar necessário.

Muito pouco destas experiências pode ser incorporado a uma memória prescritiva, que tem como objetivo reiterar a unidade do processo Fórum (e que para tanto se quer neutra, alheia ao poder e ao conflito, ao valor das tomadas de decisão e a seu próprio caráter de artefato). Pois nestes lugares íntimos, a memória do engajamento está muito perto de ferir a integridade discursiva do Fórum, o mito do diálogo horizontal sempre a ponto de ser "desfigurado" por conteúdos conflitivos. A forma habitada e densa da memória do FSM que encontramos espalhada na cidade de Porto Alegre ou incorporada aos modos de fazer e saber de uma geração para quem ele representa um momento de formação, é em si mesma uma força política potencial. Como os representantes do Acampamento em sua juventude, a memória pode entrar no jogo para jogar fora das regras e "falar as verdades que todo mundo sabia mas ninguém podia falar”. As contradições e impasses do Fórum Social Mundial são "segredos públicos”, tal como os descreve Michael Taussig: bem conhecidos, embora muitas vezes, como vimos, não possam ser articulados. O valor político desta memória ocupada de forma inarredável pelos participantes, não está em destruir o Fórum (destruindo seu 
segredo), mas no fato de que só aí se concentra uma densidade política capaz de lhe fazer justiça (Taussig, 1999, p. 2). 


\section{Comentário Final}

Como afirmamos na introdução, o percurso desta tese é um caminho de desnaturalização, baseado na problematização de categorias que funcionam como motivos condutores da constituição do Fórum Social Mundial como uma totalidade. Este trabalho de problematização, embora produza um distanciamento analítico necessário, representa também uma reaproximação. O exercício de formulação de um ponto de vista, como vimos, é também gesto estratégico: ele implica uma tomada de posição, um exercício de poder. A tese é uma tentativa de tomar a palavra, no sentido de fazer usos diferentes de uma gramática já estabelecida, recolocar a linguagem do Fórum em movimento para descolar os termos e os gestos dos usos que se tornaram normais. O caminho de argumentação, perseguindo as noções complexas de estratégia, metodologia e memória, pode ser entendido também como um novo itinerário de engajamento naquele processo, pela retomada da qualidade política dos discursos e práticas que aqui tratamos de descrever e analisar.

Neste sentido, ao buscar uma abordagem que se detém na observação dos discursos e práticas, investigando as contradições internas das formas da ação e das representações, nosso propósito é sinalizar no campo intelectual um caminho de re-politização das análises sobre o Fórum Social Mundial. Em primeiro lugar, buscamos expor como os discursos que definem o Fórum Social Mundial como uma inovação política e como um "espaço aberto", tendem a negar seu caráter estratégico, dissimulando as relações de poder e estratificações internas ao processo. Em segundo lugar, observamos como a definição do FSM como um método é profundamente ambivalente, pois proclama um processo sem hierarquias na mesma medida em que promove a articulação de um poder e um saber, separando a forma dos eventos, definida como horizontal, das estruturas verticais de tomada de decisão que põem estes eventos em funcionamento. Por último, buscamos indicar como se torna visível, na dimensão da memória que extrapola o método do espaço aberto, uma experiência do Fórum mais densa de significados e mais profundamente transformadora, na medida em que desmente a separação entre a prática política e os sentidos da vida cotidiana.

A interpretação realizada se afasta de considerações como a de Boaventura de Souza Santos segundo a qual uma leitura do Fórum Social Mundial "para ser minimamente adequada" [...] "deve ser conduzida de acordo com a epistemologia do próprio FSM. Do contrário, a avaliação será sempre negativa" (Santos, 2009a , p. 381). O que o sociólogo propõe, de fato, é um tipo particular de exercício, em que toda perspectiva que se quer "nova" deve abrir mão de empregar como material e recurso analítico as possíveis avaliações negativas - os sentimentos de frustração ou simplesmente a percepção de que há elementos da experiência que não se encaixam nas fórmulas teorizantes. Ao 
contrário, esta pesquisa se ateve a estas incongruências como pontos de apoio para um procedimento muito mais antigo que o FSM: a tomada de distância crítica com relação à aparência autoexplicativa de qualquer fenômeno social. Em outras palavras, a perspectiva "nova" que Santos propõe repete o mecanismo de exclusão atribuído à racionalidade moderna e colonial que pretende rechaçar, tornando impossível, invisível e/ou indigna de consideração - sob o signo do "velho" qualquer abordagem daquela experiência social que questione a naturalização de seus princípios internos de legitimação.

A obsessão pela avaliação positiva, de que buscamos nos afastar, resulta, em muitas análises e balanços sobre o Fórum, em uma supervalorização do discurso do método, que substitui frequentemente o exercício (talvez antigo) de descrição das contradições. Na perspectiva que toma a coerência metodológica do FSM como dado explicativo, os impasses ou conflitos tendem a ser vistos como elementos secundários, como adverte April Biccum, na medida em que a experiência política é tratada como um processo de nivelamento pedagógico, baseado no "autoconhecimento e autoinstrução", ou na "contaminação produtiva através das fronteiras ideológicas"(2005, p. 128). Ao incorporar sem maiores questionamentos esta perspectiva pedagógica, as próprias análises sobre o Fórum tendem a tornar-se parte de um projeto de alfabetização política dirigido aos movimentos sociais (Wright, 2005, p.411). A problematização do Fórum-como-método e do discurso da contaminação horizontal que buscamos construir aqui também nos afasta deste projeto. Como aponta a mesma autora, mesmo nas pedagogias críticas em que se espera que educandos e educadores sejam ambos transformados ao longo de um processo de troca cujos resultados estão sempre em aberto, "existe um perigo de que se escorregue em um tipo de pastoralismo, que tem em mente uma subjetividade pretendida, [...] algo que não confessa” (Biccum, 2005, p. 128). Assim como a forma Fórum enquanto padrão organizativo produz diálogos, mas também exclusões, invisibilidades e hierarquias, o Fórum concebido como processo de aprendizado político privilegia o desenvolvimento de formas particulares de aliança e favorece um tipo específico de conhecimento e prática ${ }^{49}$. Esta dimensão pedagógica, não cabe à análise sancionar ou reprovar: a questão do sentido de educação e aprendizado nos modos de engajamento e nas práticas de diferentes atores é antes um elemento a ser problematizado nas futuras pesquisas sobre o FSM.

As análises sobre o Fórum, como buscamos evidenciar, participam continuamente de sua produção e contribuem para definir sua relação com o contexto mais amplo dos movimentos sociais

\footnotetext{
${ }^{49}$ Durante a passagem pela Índia, a evidência de que os critérios do Fórum determinavam a exclusão de algumas formas de ação política relevantes em nível local, foi motivo para se realizasse um contra-evento simultâneo. Com o nome de Mumbai Resistance, um acampamento paralelo, auto-definido como marxista-leninista, foi convocado com o intuito de denunciar que "as forças por trás do FSM deixam muito claro o caminho que essa coalizão deve tomar, desde sua concepção [...] e no processo, oferecendo negociações, pressão pacífica e lobby como as únicas formas legítimas de luta" (Mumbai Resistence apud Biccum, 2005, p. 129).
} 
contemporâneos. A distinção entre as noções de espaço (empregada para definir a natureza política do FSM) e a noção de movimento é talvez a oposição mais comum -significativa, portanto - nas análises sobre os destinos do Fórum Social Mundial. As contradições e conflitos internos, que não aparecem expressos na metodologia, inspiram vários autores a descrevê-lo a partir dessa oposição, identificada por Coradini como principal nó do confronto velado entre diferentes modalidades de organização e legitimação entre as entidades promotoras do FSM (Coradini, 2009, p. 224). Whitaker, por sua vez, fala em "fórum como espaço" versus "fórum como movimento" (2005; 2009; 2012); Ana M. R. Prestes (2006), de seu lado, refere-se a horizontalistas versus movimentistas; Nunes (2005a) e Böhm (2005) a princípios opostos de horizontalismo e verticalismo. E se Ponniah e Fisher (2003) recorrem aos conceitos de "cadeia de equivalências" versus "hierarquia de prioridades" para explicar a diferença fundamental entre modos de articulação do discurso político presentes no contexto do Fórum, Diego Azzi elabora uma análise que o leva a descrever o jogo de forças políticas no interior do FSM como um "intenso debate sobre meios e fins da ação política" (2007, p. 157) .

A reiteração da oposição entre espaço e movimento, de meu ponto de vista, repõe a perspectiva de disputas e negociações entre duas "culturas políticas", constituídas uma contra a outra, no contexto do FSM. De maneira geral, acredito que essa oposição acaba se tornando um recurso dos intérpretes diante do problema do declínio do Fórum, de sua perda de visibilidade na imprensa internacional e da diminuição de sua força política ao longo do tempo. Permite, assim, ao coletivos e instituições filiarem-se a um dos lados de um embate sobre o futuro do Fórum ou da disputa pelo botim simbólico e social deixado após sua desaparição. Ainda é tempo de perguntar, no entanto, se a identificação dessa oposição entre "princípios" é suficiente como análise crítica, e mesmo se ela se sustenta frente ao exame detido dos modos pelos quais o FSM foi construído.

A dicotomia mencionada favorece a ocultação, casual ou intencional, do fato de que o "espaço horizontal e aberto" não se caracterizava pela ausência de hierarquias e sim pela tradução das hierarquias na linguagem técnico-política da metodologia. A concepção da horizontalidade (rede, espaço), como forma separada das relações de poder e hierarquias, está vinculada, como vimos, a uma série de outras operações bastante funcionais na manutenção da separação entre aqueles que formulam as regras do jogo e aqueles que as seguem: concebe-se a metodologia separada da estratégia, as decisões operacionais apartadas do debate político. Mais do que descrever uma verdade das relações no interior do Fórum, a fórmula "horizontalismo versus verticalismo" prescreve uma oposição fundamental para a articulação do discurso do Fórum-enquanto-método, para a valorização do Fórum como marca. Ela rentabiliza uma linguagem despolitizada de acúmulo de poder. Como aponta Biccum: “é fácil cair no fervor desse utopismo até o momento em que se 
relembra que o capitalismo neo-liberal ou pós-moderno é ele mesmo construído sobre redes não hierárquicas e opera dentro dessa lógica" (2005, p. 125).

A reflexão aqui proposta não pretende desmentir o fato de que no FSM concentram-se expectativas genuínas de produção de formas políticas capazes de superar uma crise de legitimidade de formas conhecidas de organização, e fazer frente à máxima de que "não há alternativa", à crescente mercantilização da vida e ao agravamento das condições de injustiça social. Mas, justamente para fazer justiça às expectativas, é preciso considerar os limites desta experiência. Reduzido a seu método, o Fórum é um produto e não um antídoto para o horizonte estreito que a era neoliberal impôs ao ativismo de esquerda, cuja ação resulta profundamente dependente da relação com os Estados e com o sistema de cooperação internacional.

De maneira semelhante, uma análise do Fórum identificada à tarefa de operar sua reprodução enquanto forma epistemológica, tem como horizonte apenas as relações entre engajamento político e reflexão previstas em um mundo que pretende manter-se sempre igual a si mesmo. Ela tende a se distanciar de modo crescente do problema da relação entre as práticas e a produção dos sentidos da política, sendo o seu produto teorias generalizantes que parecem ter precedência sobre a observação e a escuta atenta do conflito e da dramaticidade das escolhas estratégicas. O que este trabalho procurou fazer foi assumir o risco de um outro olhar, ao mesmo tempo mais aproximado e mais crítico, cujo resultado não pretende ensinar nenhuma lição, ao contrário, o exercício analítico ensaiado deixa mais questões em aberto do que resolvidas. Esperamos que estes “cadernos" possam retornar ao campo onde "um outro mundo" ainda está por ser construído, e que possam estimular a curiosidade dos que não desistem de reinventar tudo, quantas vezes for necessário. 


\section{Referências}

“ASSUNTO: Precisamos de sua ajuda (2005)". 7 jul. 2005. Disponível em: http://www.forumsocialmundial.org.br/download/carta_doacao_070705_por.htm. Acesso em: 20 jan. 2011.

“Carta de princípios do FórumSocial Mundial” (2001), 8 de jun. 2001. Disponível em: $\mathrm{http}: / / \mathrm{www}$.forumsocialmundial.org.br/main.php id_menu=4\&cd_language=1. Acesso em: 26 jan. 2011.

“CERIMÔNIA De Encerramento” (2005). 31 jan. 2005. Disponível em:

http://www.forumsocialmundial.org.br/dinamic.php?pagina=encerra2005_por. Acesso em: 20 jan. 2001.

“CI - Caráter, responsabilidades, composição e funcionamento” (2001). 22 jun. 2002. disponível em:

http://www.forumsocialmundial.org.br/main.php?id_menu=3_2_2_1\&cd_language=1, Acesso em: 20 jan. 2011.

"CI - Documento sobre a reunião de Barcelona, referente a reunião realizada de 28 a 30 de abril de 2002" (2002). 8 jun. 2002. Disponível em:

http://www.forumsocialmundial.org.br/main.php?id_menu=3_2_2_3\&cd_language $=1$. Acesso em: 20 jan. 2011.

“Composição do Conselho Internacional” (2009). 29 mai. 2009. Disponível em:

http://www.forumsocialmundial.org.br/main.php?id_menu=3_2_1\&cd_language $=1$. Acesso em: 20 jan. 2011.

“Documento sobre a reunião do CI em Porto Alegre de 28 e 29 de janeiro de 2002” (2002). 22 de jun. 2002. Disponível em:

http://www.forumsocialmundial.org.br/main.php?id_menu=3_2_2_4\&cd_language $=1$, Acesso em: 20 jan. 2011.

"EIXOS transversais para os 11 espaços do V FSM" (2004). 20 set. 2004. Disponível em: $\mathrm{http}: / / \mathrm{www}$. forumsocialmundial.org.br/dinami.php?pagina $=$ eixos_transversal language $=1$. Acesso em: 20 jan. 2011.

"Entenda a estrutura do Fórum Social Mundial" (2002). 27 dez. 2002. Disponível em: http://www.forumsocialmundial.org.br/dinamic.php?pagina=release_atividades. Acesso em: 20 jan. 2011.

"Esclarecimento sobre os princípios que orientam a organização do Fórum Social Mundial" (2002). 21ago. 2002. Disponível em:

http://www.forumsocialmundial.org.br/main.ph?pid_menu=4_2\&cd_language=1. Acesso em: fev. 2013.

“FSM 2001: Oficinas" (2002). 8 jun. 2002. Disponível em:

http://www.forumsocialmundial.org.br/main.php?id_menu=14_1_3\&cd_language=1. Acesso em: 27 out. 2011. 
"FSM 2006 será descentralizado" (2005). 25 jan. 2005. Disponível em: http://www.forumsocialmundial.org.br/noticias_01.php cd_news $=1542 \& c d$ language $=1$. Acesso em: 20 jan. 2011.

"Guía de Princípios para la realización de eventos FSM (Aprobada em sesión plenaria del Consejo Internacional celebrada el 24 septiembre de 2008 em Copenhague)" (2011). Disponível em: http://www.forumsocialmundial.org.br/noticias_textos.php?cd_news=722. Acesso em: 20 jan. 2011.

"Histórico do Processo FSM" (2007). Disponível em: http://www.forumsocialmundial.org.br/main.php?id_menu=2\&cd_language=1. Acesso em: 20 jan. de 2011.

“Inscrições de oficinas até 15 de novembro!” (2001). 12 nov. 2001. Disponível em: http://www.forumsocialmundial.org.br/noticias_textos.php?cd_news=551. Acesso em: 27 out. 2011.

“Metodologia do FSM 2002" (2002). 8 jun. 2002. Disponível em: http://www.forumsocialmundial.org.br/main.php?id_menu=5_2\&cd_language $=1$. Acesso em: 20 jan. 2011.

“Metodologia do FSM 2003" (2002). 27 ago. 2002. Disponível em: http://www.forumsocialmundial.org.br/main.php?id_menu=5_1\&cd_language=1. Acesso em: 20 jan. 2011.

"Metodologia do FSM 2004 (proposta preliminar)" (2003). 25 out. 2003. Disponível em: $\mathrm{http}$ ://www.forumsocialmundial.org.br/main.php?id_menu=5_3\&cd_language=1. Acesso em: 20 jan. 2011.

"Metodologia do FSM 2005" (2004). 18 out. 2004. Disponível em: http://www.forumsocialmundial.org.br/main.php?id_menu=5_4\&cd_language=1. Acesso em: 20 jan. 2011.

“Os rumos do processo Fórum Social Mundial, 21 de janeiro de 2003” (2003). 13 fev. 2003. Disponível em: http://www.forumsocialmundial.org.br/dinamic.php?pagina=ci_rumos_por. Acesso em: 20 jan. 2011.

"Porto Alegre 2005: um novo passo adiante" (2004). 20 set. 2004. Disponível em: http://www.forumsocialmundial.org.br/dinamic.php?pagina=cartaaglutinacao_por. Acesso em: 20 jan. 2011.

“Regras de funcionamento do CI FSM" (2003). 23 jul. 2003. Disponível em: http://www.forumsocialmundial.org.br/dinamic.php?pagina=ci_regras_miami_por. Acessoem : 20 jan. 2011.

"Resoluções da reunião do Conselho Internacional, em Porto Alegre, Brasil, 21 e 22 de janeiro de 2003" (2003). 20 de fev. 2003. Disponível em:

http://www.forumsocialmundial.org.br/main.php?id_menu=3 2 2\&cd language=1. Acesso em: 20 jan. 2011.

"Um outro mundo já foi bem melhor" (2010). 22 mar. 2010. Disponível em: http://www.jafoibemmelhor.blogspot.com/. Acesso em: 20 jan. 2011.

ABONG (2005). Números do FSM 2005. Biblioteca Abong, 31 jan. 2005. Disponível em: http://abong.org.br/biblioteca.php?id=3515 
AGUITON, Christophe (2002). O Mundo nos Pertence. São Paulo: Viramundo.

ALBERT, Michael (2004). “Mumbai, WSF, and Our Futures”. Site do FSM, 11 fev. 2004.

Disponível em: http://www.forumsocialmundial.org.br/dinamic.php?pagina=bal_malbert_2004_ing. Acesso em 20 jan. 2011.

(2009). “WSF: Where to now?”. In: World Social Forum: Challenging Empires. Sen e Waterman (Eds.). Montréal/Tonawanda/London: Black Rose Books.

ALVAREZ, S.; DAGNINO, E.; ESCOBAR, A. (orgs) (2000). "O cultural e o político nos movimentos sociais latino-americanos". In: Cultura e política nos movimentos sociais latinoamericanos: Novas leituras. Belo Horizonte: Ed. UFMG.

AZZI, Diego (2007). Sujeitos e utopias no movimento antiglobalização. Dissertação de Mestrado em Sociologia. São Paulo: Universidade de São Paulo.

BABA, Morjane (2003). Guérrilla Kit: ruses et techniques des nouvelles luttes anticapitalistes. Paris: Éditions La Découverte.

BELLO, Walden (2002). “When Davos Meets Porto Alegre: A Memoir”. Disponível em: http://www.forumsocialmundial.org.br/dinamic/eng_bbello.php, data de publicação no site: 24 ago. 2002 , acesso em: 20 jan. 2011.

BENSAID, Daniel (2003). Le Nouvel Internationalisme. Paris: Textuel.

BÖHM, S.; REYES, O.; SULLIVAN, S. (2005). "The organisation and politics of Social Forums". Ephemera: Theory and Politics in Organization, 5(2), p.98-101, 2005. Disponível em: http://www.ephemeraweb.org/journal/5-2/5-2editorial.pdf.

BÖHM, Steffen (2005). “Ground Zero of the Forum: Notes on a personal journey”. Ephemera: Theory and Politics in Organization 5(2), p. 134-145. Disponível em: http://www.ephemeraweb.org/journal/5-2/5-2bohm.pdf

BOTELHO, Diógenes (2005). "Fórum Social Mundial terá mural que reunirá propostas de ação". Portal PPS Brasil, disponível em: http://portal.pps.org.br/helper/printData/28555. Acesso em: 06 jan. 2005.

BURCH, S.; LEÓN, I. (2009). “The World Social Forum: Current Challenges and Future Perspectives”, In: SEN, J.; WATERMAN, P. World Social Forum: Challenging Empires. Montreal/Nova York/Londres: Black Rose, p. 292-304.

BURTON-ROSE, D.; KATSIAFICAS, G.; YUEN, E. (orgs.) (2004). Confronting Capitalism: Dispatches from a Global Movement. New York: Soft Skull Press.

CARACOL INTERGALACTIKA (2005), “The Future of the World Social Forum”. Ephemera: Theory and Politics in Organization, 5(2), p. 146-172. Disponível em: http://www.ephemeraweb.org/journal/5-2/5-2caracol.pdf

CARRUTHERS, Mary (2011). "Memória rerum, relembrando coisas", In: A técnica do pensamento, Campinas: Editora Unicamp, p. 55-95.

CASSEN, Bernard (2002). "Le tournant de Porto Alegre”. Disponível em: http://www.forumsocialmundial.org.br/dinamic/fra_1bal1.php, data de publicação no site: 24/08/2002, acesso em: 20 jan. 2011. 
CEFAÏ, Daniel (2002) 'Qu'est-ce qu'une arène publique? Quelques pistes pour une approche pragmatiste”. In: CEFAÏ, Daniel; JOSEPH, Isaac (dir.), L'Heritage du pragmatisme, Conflits D'Urbanité et épreuves de civisme, La Tour D'Aigues: Éditions de L'Aube.

(2007). Pourquoi se mobilise-t-on? Les théories de l'action collective. Paris: Éditions

La Découverte/M.A.U.S.S.

CEVASCO, M. E.; LEITE, J. C.; LOUREIRO, I. (2002). “Apresentação”. In: O Espírito de Porto Alegre. São Paulo: Paz e Terra, 2002, p. 9-14. (orgs.) (2002). O Espírito de Porto Alegre. São Paulo: Paz e Terra.

CODAS, Gustavo (2003). “Cuál es el papel del Foro Social Mundial?”. Alternativas: Revista de análisis y reflexión teológica, Ano 10, No. 25, Jan.-Jun. 2003 , Managua, p. 13-22. Disponível em: http://www.forumsocialmundial.org.br/dinamic.php?pagina=bal_gustavo_codas_es, Acesso em: 20 jan. 2011.

CONWAY, J.; SINGH, J.. "Is the World Social Forum a Transnational Public Sphere? Nancy Fraser, Critical Theory and the Conteinment of Radical Possibility. Theory, Culture \& Society, Vol. 26, No. 5, 61-84, 2009.

CONWAY, Janet (2008). "Decolonizing Knowledge/politics at the World Social Forum". Apresentação à International Studies Association, San Francisco. Disponível em: http://www.allacademic.com/meta/p251415_index.html.

CORADINI, Odaci Luiz (2009). "Os participantes e promotores do Fórum Social Mundial e as bases do militantismo". Revista Antropolítica, Niterói, No 26, p. 210- 243.

COURTIN, Christophe (2007). "Forum Social Mondial - un objet politique non identifié". Alterinfos - Diffusion de l'Information sur L'Amerique Latine. 22 jan. de 2007. Disponível em: http://www.alterinfos.org/spip.php?article800. Acesso em: fev. 2011.

DAGNINO, Evelina (2004). "Confluência perversa, deslocamentos de sentido, crise discursiva". In: La Cultura en las Crísis Lationoamericanas, GRIMSON, Alberto. P., Buenos Aires: CLACSO, p. 195-216. Disponível em:

http://bibliotecavirtual.clacso.org.ar/clacso/gt/20100918091218/10dagnino.doc

DE CERTEAU, Michel (1968). La prise de parole. Paris: Èditions du Seuil, 1994.

(1980). L'Invention du quotidien. Tome 1: Arts de faire. Paris: Folio Essais/Gallimard, 2008.

DEBORD, Guy (1955). "Introduzione a una critica della geografia urbana”. In: Guy Debord (contro) il cinema, GHEZZI, E.;TURIGLIATTO, R. (org.). Milão: Il Castoro/Biennale di Venezia.

DELLA PORTA, D.; DOERR, N. (2011). “Aprendizagem cívica no fórum social: educação democrática por meio de protesto global". Building Global Democracy. Disponível em: http://www.buildingglobaldemocracy.org/pt-pt/content/aprendizagem-civica-no-forum-socialeducacao-democratica-por-meio-de-protesto-global. Acesso em: nov. 2012.

DI GIOVANNI, Julia Ruiz (2002). "O Acampamento da Juventude”. Entrevista concedida a Maria Elisa Cevasco e Isabel Loureiro, em março de 2002. In: CEVASCO, M. E.; LEITE, J. C.; LOUREIRO, I. (orgs.). O Espírito de Porto Alegre. São Paulo: Paz e Terra. 
(2003). "Jovens, feministas, em movimento: a Marcha Mundial das Mulheres no III Acampamento Intercontinental da Juventude”. Revista Estudos Feministas, Florianópolis, 11(2): 360, julho-dezembro. p.655-660.

(2004). “Después de Mumbai". In: VIVAS, Esther, Mumbai (Foro Social Mundial 2004) - Balance y Perspectivas de un Movimiento de Movimientos. Barcelona: Icaria, p. 41-50.

(2008). Seattle, Praga, Gênova: política antiglobalização pela experiência da ação de

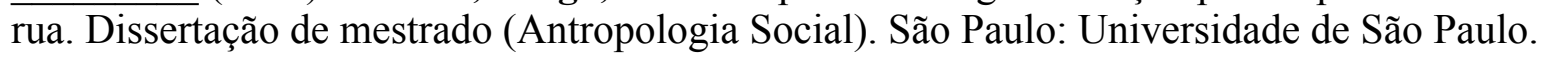

EGIREUN, J; NICHOLSON, P. (2004). "FSM, cambios necesarios". In: VIVAS, Esther, Mumbai (Foro Social Mundial 2004) - Balance y Perspectivas de un Movimiento de Movimientos.

Barcelona: Icaria, p. 91-100.

ESCOBAR, Arturo (2009). "Other Worlds Are Already Possible”. In: SEN, J.; WATERMAN, P. World Social Forum: Challenging Empires. Montreal/Nova York/Londres: Black Rose, p. 393 404.

EVERS, Tilman, "Identidade - a face oculta dos movimentos sociais". Novos Estudos Cebrap. São Paulo, V.2 No 4, p. 2-10, abr. 1984.

FISCHER, William; PONNIAH, Thomas (2003). "The World Social Forum and the Reinvention of Democracy". In: Another World is Possible: Popular Alternatives to Globalization at the World Social Forum. London/New York: Zed Books.

FOUCAULT, Michel (1969). Archeologie du Savoir. Paris: Éditions Gallimard.

(1971), "Nietzsche, la généalogie, l'histoire”. In: BACHELARD, S. et al., Hommage à Jean Hyppolite. Paris: Presses Universitaires de France.

Disponível em: http://works.bepress.com/r_gould/49

FRANCO, Luciane (2011). "Memorial do Fórum Social Mundial ficará sediado em Porto Alegre", Rádio Piratini, Governo do Estado do Rio Grande do Sul. Disponível em:

http://www.estado.rs.gov.br/audios/1/10079/Memorial-do-Forum-Social-Mundial-ficara-sediadoem-Porto-Alegre.

FREUD, Sigmund (1925), "Nota sobre o 'bloco mágico"'. In: Obras Completas, V. 16, p. 266-274. São Paulo: Companhia das Letras, 2011.

FSM 2005 - Grupo de Trabalho de Espaços (2004).

http://www.forumsocialmundial.org.br/noticias_01.php?cd_news $=1186 \& c d$ language $=1$, publicado em 20 ago. 2004.

GALEANO, Eduardo (2002). "Es posible y necesario luchar”. Disponível em:

http://www.forumsocialmundial.org.br/dinamic/esp_bgaleano.php. Acesso em: 20 jan. 2011.

GEERTZ, Clifford (1988). Obras e Vidas - O antropólogo como autor. Editora UFRJ, 2005.

GIANELLA, Miriam (sem data). "Mosaico de Pedras: arte coletiva". In: Edipe: Le portail de la psychanalyse francophone. Disponível em: http://www.oedipe.org/po/actualites/alegre/mosaique

GINZBURG, Carlo (2000). "Spie: radici di un paradigma indiziario". In: Miti, emblemi e spie: morfologia e storia. Torino: Einaudi.

(2002). "Decifrar um espaço em branco". In: Relações de força: História, retórica, prova. São Paulo: Companhia das Letras. 
GRAJEW, Oded (2011). “O pai do FSM”. Revista Fórum, Entrevista a Glauco Faria, 22 out. 2011. Disponível em: revistaforum.com.br/blog/2011/10/o-pai-do-fsm. Acesso em: jan. de 2013.

GRZYBOWSKI, Cândido (2004). "Lições de Mumbai”, disponível no site do FSM: http://www.forumsocialmundial.org.br/dinamic.php?pagina=bal_candido_por. Acesso em: 20 jan. 2011.

(2006). Nova cultura política contra a globalização neoliberal. Disponível em: $\overline{\mathrm{http}: / / \mathrm{www}}$.forumsocialmundial.org.br/noticias_textos.php?cd_news=26

GUEVARA, Ernesto Che (1971). "Stratégie et Tactique de la révolution Latinoamericaine (1962)". In: Euvres III, Textes politiques. Paris: Maspero.

HADDAD, Sérgio (2004). "Mumbai 2004: um novo passo no Fórum Social Mundial". Disponível no site do FSM:

http://www.forumsocialmundial.org.br/dinamic.php?pagina=bal_haddad_2004_por. Acesso em: 20 jan. 2011.

(2012). "Modelo do Fórum já é o caminho para a construção da alternativa". Entrevista por Agência Carta Maior. Disponível em

http://www.cartamaior.com.br/templates/materiaMostrar.cfm?materia_id=19474. Acesso em: abr. 2012.

HAERINGER, Nicolas (2005). "Mémoire et « restitution » des Forums sociaux". In: Matériaux pour l'histoire de notre temps. 2005, N. 79, p. 63-67. Disponível em:

http://www.persee.fr/web/revues/home/prescript/article/mat_0769-3206_2005_num_79_1_1044. Acesso em ago. 2012.

HARDT, Michael; NEGRI, Antonio (2003). "Foreword". In: FISCHER, William; PONNIAH, Thomas. Another World is Possible: Popular Alternatives to Globalization at the World Social Forum. London/New York: Zed Books, 2003.

HARNECKER, Marta (2005). Estratégia e Tática. São Paulo: Expressão Popular.

HARTOG, François (2003). “Ordres du Temps, régimes d'historicité” e "Des îles d'histoire”. In: Régimes d'historicité. Paris: Editions Du Seuil.

HERZFELD, Michael (1997). Intimidade Cultural: Poética Social no Estado Nação. Lisboa: Edições 70, 2008.

IBASE, Instituto Brasileiro da Análises Sociais e Econômicas (2005). Fórum Social Mundial Raio X da participação no Fórum 2005: Elementos para o debate. Rio de Janeiro. Disponível em: http://www.ibase.br/fsm2003/portugues.htm. Acesso em out. 2009.

JACOBS, Frank (2011). “Cartography's Favourite Map Monster: the Land Octopus”. Strange Maps, Big Think. Disponível em: http://bigthink.com/strange-maps/521-cartographys-favouritemap-monster-the-land-octopus

JEON, Sohi (2004). "The World Social Forum at a Crossroad". Disponível no site do FSM: http://www.forumsocialmundial.org.br/dinamic.php?pagina=bal_sohi_ing. Acesso em: 20 jan. 2011. 
JURIS, Jeffrey S. (2007). "Practicing Militant Ethnography with the Movement for Global Resistance (MRG) in Barcelona". In: SHUKAITIS, S. and GRAEBER, D. (orgs), Constituent Imagination: Militant Investigation, Collective Theorization. Oakland: AK Press. Disponível em: http://www.jeffreyjuris.com/articles.html. Acesso em 10 jan. 2011.

KLEIN, Naomi (2001). "Democratizando o movimento - quando militantes se reúnem para o primeiro Fórum Social Mundial, não há um programa único que possa conter a diversidade". In: Cercas e Janelas: na linha de frente do debate sobre globalização. São Paulo: Ed. Record, p. 253269.

(2002). “Acreditando no fim do fim da história”. in: LOUREIRO, Isabel. LEITE, José Correa; CEVASCO, Maria Elisa (orgs.). O Espírito de Porto Alegre. São Paulo: Paz e Terra, 2002. p. 265-276.

(2003). "Cut the strings: The new grassroots politics needs more democracy not more political strongmen”, The Guardian, 1 fev. 2003. Disponível em:

http://www.guardian.co.uk/politics/2003/feb/01/greenpolitics.globalisation

(2003a). "More Democracy - Not More Political Strongmen". The Guardian, 03 de fevereiro de 2003. Disponível em:

http://www.forumsocialmundial.org.br/dinamic.php?pagina=balanco_klein_2003in. Acesso em: 20 jan. 2011.

KOSELLECK, Reinhardt (1979). "Espaço de Experiência e Horizonte de Expectativa - duas categorias históricas". In: Futuro Passado: contribuição à semântica dos tempos históricos. Rio de Janeiro: PUC/Contraponto, 2011.

LEITE, José Corrêa (2003). "Fórum Social Mundial: uma invenção política”. In: Fórum Social Mundial: A História de uma Invenção Política. São Paulo: Perseu Abramo, p. 61-90.

(2004). “Novos Caminhos para o Fórum Social Mundial”, 4 jan. 2004. Disponível em: http://www.forumsocialmundial.org.br/dinamic.php?pagina=bal_zecorrea_por. Acesso em: 20 jan. 2011.

(2005). As invenções da política: sobre a existência da política e suas transformações. Tese (Doutorado em Ciências Sociais). São Paulo: Pontifícia Universidade Católica de São Paulo.

MARCHA MUNDIAL DAS MULHERES. "EI Foro Social Mundial 2003 - Visto por las mujeres de la Marcha Mundial de las Mujeres". 14 mar. 2003. Disponível em:

http://www.forumsocialmundial.org.br/dinamic.php?pagina=bal_march_mulher_esp. Acesso em: 20 jan. 2011

MARINGONI, Gilberto (2005). "O melhor e o mais político dos Fóruns”. Agência Carta Maior, 31/1, 20 fev. 2005. Disponível em:

http://www.forumsocialmundial.org.br/dinamic.php?pagina=maringa.

MASSIAH, Gustave (2011). Une Stratégie Altermondialiste. Paris: Éditions La Découverte.

MEDEROS, José Miguel Hérnandez (2011). "La relación Metodología-Estrategia: Fórum Social

Mundial 2011, Dacar Senegal”. Disponível em: http://fsm2011.org/br/node/513. Acesso em: jan. 2013.

MONEREO, Manuel (2000). "De Porto Alegre a Porto Alegre: la emergencia del nuevo sujeto politico”. In: SEOANE, J.; TADDEI, E. Resistencias Mundiales: De Seattle a Porto Alegre. Buenos Aires: CLACSO. 
MUELLER, Tazio (2005). "Notes from WSF 2005: The Good, the Bad and the Ugly", Ephemera: Theory and Politics in Organization, volume 5(2), p. 273-276. Disponível em: http://www.ephemeraweb.org/journal/5-2/5-2mueller.pdf

NUNES, Rodrigo (2005). “The Intercontinental Youth Camp as the Unthought of the World Social Forum". Ephemera: Theory and Politics in Organization, 5(2), p. 277-296, 2005. Disponível em: http://www.ephemeraweb.org/journal/5-2/5-2nunes1.pdf.

(2005a). "Networks, Open Spaces, Horizontality: Instantiations". Ephemera: Theory and Politics in Organization, 5(2), p. 297-318, 2005. Disponível em: http://www.ephemeraweb.org/journal/5-2/5-2nunes2.pdf.

(2009). "Dictionary of received ideas (in the interest of passing them on)". Znet, 10 ago. 2009. Disponível em: http://www.zcommunications.org/dictionary-of-received-ideas-in-theinterest-of-passing-them-on-by-rodrigo-nunes.

OSTERWEIL, Michal (2009).“De-centering the Forum: Is Another Critique od the Forum Possible? In: SEN, J.; WATERMAN, P. World Social Forum: Challenging Empires. Montreal/Nova York/Londres: Black Rose, p. 145-153.

P., Fernando (2012). "Biblioteca Social Mundial”. Tecnologia e Ciências da Informação: blog profissional de Fernando P. , bibliotecário, 26 jan. 2012. Disponível em:

http://tci.fernandop.info/?p=363.

PIRES, Lucas Rodrigues (2005). “Observações sobre o Fórum Social Mundial”. Digestivo Cultural, 21 fev. 2005. Disponível em:

http://www.digestivocultural.com/colunistas/imprimir.asp?codigo=1559. Acessado em abr. 2012.

PLANELLS, Antoni Verger i (2007). "Sistematizando experiencias: análisis y recreación de la acción colectiva desde la educación popular". Revista de educación, 343, p. 623-645 . Madrid: Instituto Nacional de Evaluación Educativa. Disponível em: http://www.revistaeducacion.mec.es/re343_26.html.

PURKAYASTHA, Prabir. "World Social Forum from Porte Alegre to Mumbai: Some Reflections". 29 mar. 2004. Disponível em:

http://www.forumsocialmundial.org.br/dinamic.php?pagina=bal_prabir_2004 ing. Acesso em: 20 jan. 2011.

RABELO, Ana Maria Prestes (2006). A participação política em tempos de globalização: O Fórum Social Mundial inaugura o movimento social global. Dissertação de Mestrado em Ciência Política. Belo Horizonte: Universidade Federal de Minas Gerais.

REYES, Oscar (2005). "World and European Social Forums: A Bibliography”. Ephemera: Theory and Politics in Organization, 5(2), p. 334-343. Disponível em:

http://www.ephemeraweb.org/journal/5-2/5-2reyes.pdf. Acesso em: out. 2009.

ROY, Arundhati (2004). “Los Pavos disfrutan el dia de Acción de Gracias?”. In: VIVAS, Esther.

Mumbai (Foro Social Mundial 2004) - Balance y Perspectivas de un Movimiento de Movimientos, 2004, Icaria, Barcelona. P. 113 - 124.

SANTOS, Boaventura de Souza (2005). O Fórum Social Mundial - Manual de Uso, São Paulo: Editora Cortez. (2005a). "The Future of The World Social Forum: the work of translation".

Development, No 48(2), p. 15-200. 
(2005b). "A crítica da governação neoliberal: O Fórum Social Mundial como política e legalidade cosmopolita subalterna”. Revista Crítica de Ciências Sociais, 72, Outubro de 2005, p. $7-44$.

(2009). "The World Social Forum: toward a counter-hegemonic globalization". In:

SEN, J.; WATERMAN, P. World Social Forum: Challenging Empires. Montreal/Nova York/Londres: Black Rose, p. 191-204.

(2009a). "The World Social Forum and the Future". In: SEN, J.; WATERMAN, P. World Social Forum: Challenging Empires. Montreal/Nova York/Londres: Black Rose, p. 378386.

SEN, Jai (2009). "How Open? The Forum as Logo, the Forum as Religion". In: SEN, J.;

WATERMAN, P. World Social Forum: Challenging Empires. Montreal/Nova York/Londres:

Black Rose, p. 162-184.

SEN, J.; WATERMAN, P. (orgs).(2008). World Social Forum: Challenging Empires. Montreal/Nova York/Londres: Black Rose.

SEOANE, J.; TADDEI, E. (2000). Resistencias Mundiales: De Seattle a Porto Alegre. Buenos Aires: CLACSO.

SHIVA, Vandana (2004). "La lucha epica contra el capital”. In: VIVAS, Esther, Mumbai (Foro Social Mundial 2004) - Balance y Perspectivas de un Movimiento de Movimientos. Barcelona: Icaria, p. 87-90.

TABBUSH, Constanza (2005). "Civil Society in United Nations Conferences: A literature Review", Civil Society and Social Movements Programme Paper, Number 17, United Natons Research Intitute for Social Development. Disponível em: http://www.unrisd.org.

TARROW, Sidney (1999). Cycles of Contention. In: Power in movement. Cambridge: Cambridge University Press, 1999, $2^{\mathrm{a}}$ ed., p.141-160.

(2005). The new transnational activism. Cambridge: Cambridge University Press.

TAUSSIG, Michael (1999). Defacement: Public Secrecy and the Labor of the Negative, Stanford: Stanford University Press.

TEIVANEN, Teivo (2003). "World Social Forum: what should it be when it grows up?". 23 set. 2002. Disponível no site do FSM:

http://www.forumsocialmundial.org.br/dinamic.php?pagina=bal teivo_ing. Acesso em: 20 jan. 2011.

(2009). "The World Social Forum: Arena or Actor", In: SEN, J.; WATERMAN, P. World Social Forum: Challenging Empires. Montreal/Nova York/Londres: Black Rose, p. 94-103.

TOUSSAINT, Eric (2003). "Forum Social Mondial: du Brésil à 1 Inde - internationaliser l'autre mondialisation". Entrevista realizada por Sergio Ferrari em 24 abr. 2003. Disponível em: http://www.forumsocialmundial.org.br/dinamic.php?pagina=bal_toussaint_fr. Acesso em: 20 jan. 2011.

VIVAS, Esther (2004). “De Porto Alegre a Mumbai”. In: Mumbai (Foro Social Mundial 2004) Balance y Perspectivas de un Movimiento de Movimientos. Barcelona: Icaria, p. 7-20. 
(org.) (2004a). Mumbai - Foro Social Mundial 2004: balance y perspectivas de un movimiento de movimientos. Barcelona: Editorial Icaria.

WAINWRIGHT, Hilary (2004). "From Mumbai with hope". Red Pepper, mar. 2004. Disponível em: http://www.forumsocialmundial.org.br/dinamic.php?pagina=bal hilary_2004 ing. Acesso em: 20 jan. 2011.

WALLERSTEIN, Immanuel (2004). "La fuerza creciente del Foro Social Mundial”, in: VIVAS, Esther. (Org.). Mumbai - Foro Social Mundial 2004: balance y perspectivas de un movimiento de movimientos. Barcelona: Editorial Icaria, p. 21 - 26.

(2004). “The rising strength of the World Social Forum”. 20 fev. 2004. Disponível em: http://www.forumsocialmundial.org.br/dinamic.php?pagina=bal_wallerste_2004_i. Acesso em: 20 jan. 2011.

WATERMAN, Peter (2009). "The Secret of Fire”. In: SEN, J.; WATERMAN, P. World Social Forum: Challenging Empires. Montreal/Nova York/Londres: Black Rose, p. 109-125.

WEISSHEIMER, Marco Aurélio (2005). "Território Social Mundial deve receber 100 mil". Agência Carta Maior, 18 jan. 2005. Disponível em:

http://www.cartamaior.com.br/templates/materiaImprimir.cfm?materia_id=10952.

WHITAKER, Francisco (2003). "Notes about the World Social Forum". 17 mar. 2003.

Disponível em: http://www.forumsocialmundial.org.br/dinamic.php?pagina=bal_whitaker_ing. Acesso em: 20 jan. 2011.

(2004). “Fórum Social Mundial: origens e objetivos”. 20 jun. 2004. Disponível em: http://www.forumsocialmundial.org.br/dinamic.php?pagina=origem_fsm_por. Acesso em: 20 jan. 2011.

Loyola.

(2005). Desafio do Fórum Social Mundial: um Modo de Ver. São Paulo: Edições

(2005a). "Fórum Social Mundial de 2005 - avanços e perspectivas”. Memória FSM 2005, 20 mar. 2005. Disponível em:

http://www.forumsocialmundial.org.br/dinamic.php?pagina=avalia_whitaker_2005

(2009). "The World Social Forum as an Open Space". In: SEN, J.; WATERMAN, P.

World Social Forum: Challenging Empires. Montreal/Nova York/Londres: Black Rose, p. 81-93

(2012). "Fórum Social Mundial: espaço ou movimento? Pensando o futuro do

Conselho Internacional do FSM em novas perspectivas". Carta dirigida ao Grupo de Trabalho sobre o futuro do Conselho Internacional, 6 dez. 2012, comunicação pessoal.

WRIGHT, Colin (2005). "Opening Spaces: Power, Participation and Plural Democracy at the World Social Forum”, Ephemera: Theory and Politics in Organization, 5(2), p. 409-422.

Disponível em: http://www.ephemeraweb.org/journal/5-2/5-2wright.pdf

(2005). “Opening Spaces: Power, Participation and Plural Democracy at the World Social Forum”, Ephemera, 5(2), p.409 - 422. Disponível em: http://www.ephemeraweb.org/journal/5-2/5-2wright.pdf 


\section{Anexo A: Carta de Princípios do Fórum Social Mundial}

Disponível em: http://www.forumsocialmundial.org.br/main.php?id_menu=4\&cd_language=1

O Comitê de entidades brasileiras que idealizou e organizou o primeiro Fórum Social Mundial, realizado em Porto Alegre de 25 a 30 de janeiro de 2001, considera necessário e legítimo, após avaliar os resultados desse Fórum e as expectativas que criou, estabelecer uma Carta de Princípios que oriente a continuidade dessa iniciativa. Os Princípios contidos na Carta, a ser respeitada por tod@s que queiram participar desse processo e organizar novas edições do Fórum Social Mundial, consolidam as decisões que presidiram a realização do Fórum de Porto Alegre e asseguraram seu êxito, e ampliam seu alcance, definindo orientações que decorrem da lógica dessas decisões.

1. O Fórum Social Mundial é um espaço aberto de encontro para o aprofundamento da reflexão, o debate democrático de idéias, a formulação de propostas, a troca livre de experiências e a articulação para ações eficazes, de entidades e movimentos da sociedade civil que se opõem ao neoliberalismo e ao domínio do mundo pelo capital e por qualquer forma de imperialismo, e estão empenhadas na construção de uma sociedade planetária orientada a uma relação fecunda entre os seres humanos e destes com a Terra.

2. O Fórum Social Mundial de Porto Alegre foi um evento localizado no tempo e no espaço. A partir de agora, na certeza proclamada em Porto Alegre de que "um outro mundo é possível", ele se torna um processo permanente de busca e construção de alternativas, que não se reduz aos eventos em que se apóie.

3. O Fórum Social Mundial é um processo de caráter mundial. Todos os encontros que se realizem como parte desse processo têm dimensão internacional.

4. As alternativas propostas no Fórum Social Mundial contrapõem-se a um processo de globalização comandado pelas grandes corporações multinacionais e pelos governos e instituições internacionais a serviço de seus interesses, com a cumplicidade de governos nacionais. Elas visam fazer prevalecer, como uma nova etapa da história do mundo, uma globalização solidária que respeite os direitos humanos universais, bem como os de tod@s@s cidadãos e cidadãs em todas as nações e o meio ambiente, apoiada em sistemas e instituições internacionais democráticos a serviço da justiça social, da igualdade e da soberania dos povos.

5. O Fórum Social Mundial reúne e articula somente entidades e movimentos da sociedade civil de todos os países do mundo, mas não pretende ser uma instância representativa da sociedade civil mundial.

6. Os encontros do Fórum Social Mundial não têm caráter deliberativo enquanto Fórum Social Mundial. Ninguém estará, portanto autorizado a exprimir, em nome do Fórum, em qualquer de suas edições, posições que pretenderiam ser de tod@s@s seus/suas participantes.@s participantes não devem ser chamad@s a tomar decisões, por voto ou aclamação, enquanto conjunto de participantes do Fórum, sobre declarações ou propostas de ação que@s engajem a tod@s ou à sua maioria e que se proponham a ser tomadas de posição do Fórum enquanto Fórum. Ele não se constitui portanto em instancia de poder, a ser disputado pelos participantes de seus encontros, nem pretende se constituir em única alternativa de articulação e ação das entidades e movimentos que dele participem. 
7. Deve ser, no entanto, assegurada, a entidades ou conjuntos de entidades que participem dos encontros do Fórum, a liberdade de deliberar, durante os mesmos, sobre declarações e ações que decidam desenvolver, isoladamente ou de forma articulada com outros participantes. O Fórum Social Mundial se compromete a difundir amplamente essas decisões, pelos meios ao seu alcance, sem direcionamentos, hierarquizações, censuras e restrições, mas como deliberações das entidades ou conjuntos de entidades que as tenham assumido.

8. O Fórum Social Mundial é um espaço plural e diversificado, não confessional, não governamental e não partidário, que articula de forma descentralizada, em rede, entidades e movimentos engajados em ações concretas, do nível local ao internacional, pela construção de um outro mundo.

9. O Fórum Social Mundial será sempre um espaço aberto ao pluralismo e à diversidade de engajamentos e atuações das entidades e movimentos que dele decidam participar, bem como à diversidade de gênero, etnias, culturas, gerações e capacidades físicas, desde que respeitem esta Carta de Princípios. Não deverão participar do Fórum representações partidárias nem organizações militares. Poderão ser convidados a participar, em caráter pessoal, governantes e parlamentares que assumam os compromissos desta Carta.

10. O Fórum Social Mundial se opõe a toda visão totalitária e reducionista da economia, do desenvolvimento e da história e ao uso da violência como meio de controle social pelo Estado. Propugna pelo respeito aos Direitos Humanos, pela prática de uma democracia verdadeira, participativa, por relações igualitárias, solidárias e pacíficas entre pessoas, etnias, gêneros e povos, condenando todas as formas de dominação assim como a sujeição de um ser humano pelo outro.

11. O Fórum Social Mundial, como espaço de debates, é um movimento de idéias que estimula a reflexão, e a disseminação transparente dos resultados dessa reflexão, sobre os mecanismos e instrumentos da dominação do capital, sobre os meios e ações de resistência e superação dessa dominação, sobre as alternativas propostas para resolver os problemas de exclusão e desigualdade social que o processo de globalização capitalista, com suas dimensões racistas, sexistas e destruidoras do meio ambiente está criando, internacionalmente e no interior dos países.

12. O Fórum Social Mundial, como espaço de troca de experiências, estimula o conhecimento e o reconhecimento mútuo das entidades e movimentos que dele participam, valorizando seu intercâmbio, especialmente o que a sociedade está construindo para centrar a atividade econômica e a ação política no atendimento das necessidades do ser humano e no respeito à natureza, no presente e para as futuras gerações.

13. O Fórum Social Mundial, como espaço de articulação, procura fortalecer e criar novas articulações nacionais e internacionais entre entidades e movimentos da sociedade, que aumentem, tanto na esfera da vida pública como da vida privada, a capacidade de resistência social não violenta ao processo de desumanização que o mundo está vivendo e à violência usada pelo Estado, e reforcem as iniciativas humanizadoras em curso pela ação desses movimentos e entidades.

14. O Fórum Social Mundial é um processo que estimula as entidades e movimentos que dele participam a situar suas ações, do nível local ao nacional e buscando uma participação ativa nas instâncias internacionais, como questões de cidadania planetária, introduzindo na agenda global as práticas transformadoras que estejam experimentando na construção de um mundo novo solidário. 
Aprovada e adotada em São Paulo, em 9 de abril de 2001, pelas entidades que constituem o Comitê de Organização do Fórum Social Mundial, aprovada com modificações pelo Conselho

Internacional do Fórum Social Mundial no dia 10 de junho de 2001. 


\section{Anexo B: Temário e esquemas metodológicos do FSM entre 2001 a 2005}

I. Temas do FSM de 2001 a 2005

Fonte: www.forumsocialmundial.org

2001

Temas da primeira edição do Fórum Social Mundial, realizada de 25 a 30 de janeiro de 2001, em Porto Alegre, Brasil.

- A produção de riquezas e a reprodução social

- $\mathrm{O}$ acesso às riquezas e à sustentabilidade

- A afirmação da sociedade civil e dos espaços públicos

- $\quad$ Poder político e ética na nova sociedade

$-$

2002

Temas da segunda edição do Fórum Social Mundial, realizada de 31 de janeiro a 5 de fevereiro de 2002, em Porto Alegre, Brasil.

- A produção de riquezas e a reprodução social

- $\mathrm{O}$ acesso às riquezas e à sustentabilidade

- A afirmação da sociedade civil e dos espaços públicos

- Poder político e ética na nova sociedade

2003

Temas da terceira edição do Fórum Social Mundial, realizada de 23 a 28 de janeiro de 2003, em Porto Alegre, Brasil.

- Desenvolvimento democrático e sustentável

- Princípios e valores, direitos humanos, diversidade e igualdade

- Mídia, cultura e alternativas à mercantilização e homogeneização

- Poder político, sociedade civil e democracia

- Ordem mundial democrática, luta contra a militarização e promoção da paz

2004

Temas da quarta edição do Fórum Social Mundial, realizada de 26 a 31 de janeiro de 2004, em Mumbai, Índia

Eixos temáticos:

- Democracia, segurança ecológica e economia

- Discriminação, dignidade e direitos

- Mídia, informação e conhecimento

- Militarismo, guerra e paz

Eixos transversais:

- Globalização imperialista

- Patriarcado

- Regimes de castas e racismo e exclusões sociais

- Sectarismo religioso, políticas de identidade e fundamentalismo (comunalismo)

- Militarismo e paz

2005

Espaços temáticos da quinta edição do Fórum Social Mundial, realizada de 16 a 21 de janeiro de 2005, em Porto Alegre, Brasil. 
- Afirmando e defendendo os bens comuns da Terra e dos povos - Como alternativa à mercantilização e ao controle das transnacionais

- Arte e criação: construindo as culturas de resistência dos povos

- Comunicação: práticas contra-hegemônicas, direitos e alternativas

- Defendendo as diversidades, pluralidade e identidades

- Direitos humanos e dignidade para um mundo justo e igualitário

- Economias soberanas pelos e para os povos - Contra o capitalismo neoliberal

- Ética, cosmovisões e espiritualidades - Resistências e desafios para um novo mundo

- Lutas sociais e alternativas democráticas - Contra a dominação neoliberal

- Paz e desmilitarização - Luta contra a guerra, o livre comércio e a dívida

- Pensamento autônomo, reapropiação e socialização do conhecimento (dos saberes) e das tecnologias

- Rumo à construção de uma ordem democrática internacional e integração dos povos

Eixos transversais

- Emancipação social e dimensão política das lutas

- Luta contra o capitalismo patriarcal

- Lutas contra o racismo e outras formas de exclusão baseadas na ascendência

- Gênero

- Diversidade

II. Estrutura metodológica dos eventos FSM de 2002, 2003 e 2005

a) Atividades propostas para o Fórum Social Mundial 2002 :

Disponível em: http://www.forumsocialmundial.org.br/main.php?id_menu=5_2\&cd_language=1

Conferências - têm o objetivo de mostrar propostas, plataformas e alternativas que estão sendo discutidas por redes, movimentos e organizações da sociedade civil que lutam contra a globalização neoliberal. Cada conferência é um espaço de debates, de construção de consensos e de diversidade de propostas. É uma oportunidade de análise e de reflexão em torno dos eixos temáticos.

Conferências Especiais - são espaços para a divulgação e debate de propostas elaboradas em grandes eventos que precederam o FSM2002 (como o de Havana sobre Segurança Alimentar e o Fórum Mundial de Educação de Porto Alegre).

Seminários - sua finalidade é permitir a identificação, a elaboração e o aprofundamento em torno a temáticas específicas, bem como o debate público e a socialização de reflexões estratégicas.

Serão propostos prioritariamente por redes/organizações internacionais do Conselho Internacional do FSM. São oportunidades de se criar uma nova temática, construí-la, aprofundá- la, debatê-la e fazê-la conhecida.

Oficinas - seu objetivo é abrir espaços para o encontro, a troca de experiências, a articulação, o planejamento e a definição de estratégias de grupos, coalizões e redes. É uma oportunidade de pensar propostas para ações presentes e futuras. Nas oficinas, os participantes poderão formular propostas, assim como nas conferências. As oficinas podem, ainda, ser organizadas em torno dos mesmos temas das conferências.

Testemunhos - personalidades de reconhecida trajetória em prol da liberdade e dignidade humana apresentarão suas experiências, análises e visões.

Atos políticos - focados em determinadas campanhas, como o Tribunal de Dívida Externa e a proposta de uma assembléia sobre a Área de Livre Comércio das Américas (ALCA).

Coletivas de imprensa - pretendem dar uma versão integrada do desenvolvimento dos trabalhos, particularmente das conferências e dos conjuntos de propostas discutidos durante o FSM. Fóruns 
especiais - já estão previstos o Fórum de Autoridades Locais e o Fórum de Parlamentares. Estão ainda em discussão um fórum de centrais sindicais e outro de organizações ligadas ao trabalho. Também está sendo discutida a proposta de um Fórum específico sobre a paz, para tratar a questão dos conflitos e sua resolução, buscando dar uma resposta ao cenário provocado pelos atos de terrorismo do dia 11 de setembro.

Programação cultural - espaço aberto para eventos culturais que fortaleçam a mensagem e a identidade pública do FSM como evento político-cultural. Será uma oportunidade para articulações e encontros entre os participantes do Fórum.

Acampamento da Juventude e Acampamento Indigena - desenvolverão também programações específicas dentro de seus espaços, abertas à participação geral.

Conferências -

- Os puxadores das conferências - uma rede, uma coalizão, uma campanha ou uma combinação entre elas - devem elaborar previamente suas propostas de conferências, com justificativas e análise de fundamentação.

- Os (as) debatedores (as) de cada conferência terão o papel de colaboração crítica, dissecando as possibilidades e os limites das propostas apresentadas pelos puxadores, ou, ainda, apontando propostas novas e sugerindo outras abordagens e análises.

- O animador ou animadora terá um papel chave na conferência. A animação deve trazer organicidade aos trabalhos, facilitando a articulação de todas as contribuições e levando a conferência a uma direção essencialmente propositiva. Os animadores poderão contribuir com o debate enviando análises, ensaios e propostas sobre os temas para a Secretaria Executiva do FSM, indicando o eixo e a conferência.

b) Metodologia - Programação do Fórum Social Mundial 2003

Data de publicação: 17 de agosto de 2002.

Disponível em: http://www.forumsocialmundial.org.br/main.php?id_menu=5_2\&cd_language=1

O Grupo de Trabalho de Metodologia do Conselho Internacional elaborou um documento com os critérios para a programação do Fórum Social Mundial 2003. Em breve publicaremos o documento na íntegra. Veja aqui quais serão as principais atividades do FSM:

- Cinco eixos temáticos

- Conferências

- Painéis

- Testemunhos

- Seminários

- Oficinas

- Mesas de diálogo e controvérsia

- Fóruns Sociais pelo Mundo: espaços para os debates sobre os Fóruns Sociais Regionais, Temáticos e locais

Compete às organizações-membro do CI, em articulação com a Secretaria Internacional do FSM, sugerir atores para a composição de todas as atividades, com exceção das oficinas, propostas e organizadas diretamente pelos delegados participantes do evento.

O Conselho Internacional definiu cinco eixos temáticos para o FSM 2003. Cada eixo é concebido como catalisador de preocupações, propostas e estratégias que já são desenvolvidas pelas organizações participantes do processo Fórum Social Mundial. Os cinco eixos temáticos são:

- Desenvolvimento democrático e sustentável

- Princípios e valores, direitos humanos, diversidade e igualdade

- Mídia, cultura e contra-hegemonia 
- Poder político, sociedade civil e democracia

- Ordem mundial democrática, combate a militarização e promoção da paz

O Grupo de Trabalho, composto por membros do CI, deverá detalhar os encaminhamentos dos eixos temáticos e de propostas de subtemas - que poderão compor os painéis e as conferências - até a próxima reunião do CI em Florença, Itália.

Conferências - As conferências têm a finalidade de socializar visões e análises para o grande público do Fórum Social Mundial. Devem contribuir para o fortalecimento de um movimento de opinião bastante amplo voltado para a necessidade, a possibilidade e a urgência de construir "outros mundos" diante das ameaças e limites da globalização econômico-financeira do neoliberalismo. A proposta é que seja organizada pelo menos uma conferência por eixo temático.

Painéis - Os painéis, estruturados por eixo temático, são, por excelência, o mapa de ações e a face pública do FSM como Fórum da sociedade civil mundial. Trata-se de uma explicitação das grandes questões, propostas e estratégias com sua diversidade de inserções e visões, em sua ação pela mudança da globalização neoliberal e pela emergência de "outros mundos possíveis". Testemunhos - Os testemunhos são depoimentos de personalidades - ou grupos de pessoas que atuam numa mesma área - cujas trajetórias exemplares de vida e ação em prol da liberdade e da dignidade humanas apontam caminhos para um novo mundo. São uma forma de valorizar o patrimônio político-cultural do campo das entidades, organizações e movimentos que constroem o FSM.

Mesas de diálogo e controvérsia - São um espaço específico no interior do FSM para confrontar visões e propostas de delegados com convidados de partidos políticos, governos e organizações da ONU. Trata-se de eleger questões "quentes" em que o estabelecimento do diálogo e da controvérsia, segundo regras previamente concertadas, possa ser útil na própria explicitação de propostas e estratégias da sociedade civil mundial.

Seminários - Os seminários são espaços de reflexão conjunta sobre o "estado da questão" e o apontamento de possíveis desdobramentos em torno a uma temática delimitada dos subtemas em cada eixo. Visam tanto elaborar e aprofundar o diagnóstico destas questões como discutir propostas e estratégias referentes à temática. Trata-se de um momento essencial para a elaboração conjunta, agregando organizações, movimentos e redes em torno dos temas, procurando fortalecer o bloco de sujeitos portadores das propostas e ações.

Oficinas - As oficinas são atividades propostas pelas entidades, movimentos e organizações que se inscrevem como delegados no FSM 2003. Elas são a fábrica do Fórum, uma espécie de laboratório civil mundial, e têm a finalidade de permitir o encontro, a troca de experiências, a articulação, o planejamento e a definição de estratégias de grupos, coalizões, redes, movimentos, organizações, sempre pensando em sua ação presente e futura.

Fóruns Sociais pelo Mundo - Haverá um espaço reservado para os debates sobre os Fóruns Sociais Regionais e Temáticos. Serão organizadas atividades permanentes e criadas facilidades para que os diferentes Fóruns Sociais que se realizaram previamente ao de Porto Alegre (temático Argentina, regionais Europeu, Asiático e Pan-amazônico e outros nacionais e locais) possam manifestar-se. Será uma espécie de local de exibição, encontro e debate aberto durante todo o tempo de realização do FSM 2003, com um programa específico a ser concertado com os que tomaram a iniciativa dos diferentes Fóruns. Trata-se de dar visibilidade ao processo de mundialização do FSM, respeitando a autonomia, características e dinâmica específica de cada Fórum realizado.

c.) Metodologia do FSM 2005

Data de publicação: 18 de outubro de 2004.

Disponível em: http://www.forumsocialmundial.org.br/main.php?id_menu=5_2\&cd_language=1

Na quinta edição do Fórum Social Mundial, a construção da programação seguiu uma nova 
metodologia, que busca ampliar a convergência, multiplicar os diálogos durante o evento e evitar a repetição desarticulada de atividades sobre o mesmo tema. O programa do encontro foi constituído a partir das atividades autogestionadas propostas pelas organizações participantes do FSM 2005. A nova metodologia aprovada pelo Conselho Internacional em abril de 2004 teve como primeiro passo prático a realização de uma Consulta Temática, um questionário amplamente divulgado que buscou identificar que lutas, questões, problemas, propostas e desafios as diversas organizações que participam do processo FSM consideram importante discutir no FSM 2005 e que atividades tinham a intenção de organizar em Porto Alegre. Da análise das respostas pelas comissões de Metodologia e Conteúdo do Conselho Internacional, resultaram 11 espaços temáticos que organizaram todas as atividades propostas para o FSM 2005:

01. Afirmando e defendendo os bens comuns da Terra e dos povos - Como alternativa à mercantilização e ao controle das transnacionais

02. Arte e criação: construindo as culturas de resistência dos povos

03. Comunicação: práticas contra-hegemônicas, direitos e alternativas

04. Defendendo as diversidades, pluralidade e identidades

05. Direitos humanos e dignidade para um mundo justo e igualitário

06. Economias soberanas pelos e para os povos - Contra o capitalismo neoliberal

07. Ética, cosmovisões e espiritualidades - Resistências e desafios para um novo mundo

08. Lutas sociais e alternativas democráticas - Contra a dominação neoliberal

09. Paz e desmilitarização - Luta contra a guerra, o livre comércio e a dívida

10. Pensamento autônomo, reapropiação e socialização do conhecimento (dos saberes) e das tecnologias

11. Rumo à construção de uma ordem democrática internacional e integração dos povos

Também foram identificado 3 eixos transversais:

01. Emancipação social e dimensão política das lutas

02. Luta contra o capitalismo patriarcal

03. Luta contra o racismo

\section{Grupos aglutinadores}

Uma das grandes novidades da metodologia de 2005 foi a formação dos grupos aglutinadores, que são conjuntos de organizações que trabalham em torno de temas comuns e que estão abertas a articularem suas atividades com as das de outras organizações.

Inscrições antecipadas

Neste novo desenho de metodologia para a construção da programação, foi fundamental que as diversas organizações participantes do processo FSM realizassem antecipadamente sua(s) proposta(s) de atividade, mesmo que esta(s) ainda não tivessem um formato definitivo. Essa iniciativa permitiu que outras entidades pudessem visualizar as atividades inscritas por meio da consulta pública disponível no site de inscrições. Foi com base nessa pesquisa que foi possível iniciar o processo de aglutinação de atividades.

Em 2005, ao propor uma atividade autogestionada, cada organização teve de vinculá-la a um dos 11 espaços temáticos definidos. A novidade é que essa informação estava disponível numa consulta pública, de forma que outras organizações tivessem acesso aos contatos das entidades inscritas e aos conteúdos das atividades propostas. Para possibilitar esse processo, o site das inscrições contou com um sistema de busca para as organizações encontrarem as demais entidades com temas e propostas em comum, seja por palavra-chave ou por propostas (de atividades e por espaço temático).

Além disso, outro importante instrumento para articular as diversas propostas, temas, lutas, desafios, campanhas foram as palavras-chave. Em 2004, a ficha de inscrição conteve uma lista inicial com 117 sugestões, formulada a partir da Consulta Temática e das palavras-chaves das 
edições anteriores do FSM. 


\section{Anexo C: Financiadores dos Fóruns Sociais Mundiais de 2003 e 2005.}

\section{(na ordem que aparecem na fonte)}

\begin{tabular}{|l|l|}
\hline Patrocinadores e apoiadores do FSM 2003 & Patrocinadores e apoiadores do FSM 2005 \\
\hline Governo do Estado do RS & Governo do Estado do RS \\
Prefeitura de Porto Alegre & Prefeitura de Porto Alegre \\
Petrobrás & Ministério do Turismo \\
Fundação Banco do Brasil & Governo Federal do Brasil \\
Cafod & Banco do Brasil \\
Comité Catholique Contre la Faim et pour le & Caixa Econômica Federal \\
développement & Correios \\
EED - Evangelischer Entwicklungsdienst & Eletrobrás \\
Fundação Heinrich Böll & Infraero \\
ICCO & Petrobrás \\
Misereor & Furnas \\
Novib & EED - Evangelischer Entwicklungsdienst \\
OXFAM Belgica & Christian Aid \\
Oxfam America & Comité Catholique Contre la Faim et pour le \\
Oxfam Great Britain & développement \\
Oxfam Hong Kong & Novib \\
Oxfam Netherlands & Cafod \\
Oxfam Spain & Rockefeller Brothers Fund \\
Misereor \\
Icco - Inter Churc Coop Organization \\
\hline
\end{tabular}

Fonte: www.forumsocialmundial.org

\footnotetext{
${ }^{50} \mathrm{Em}$ ambas as colunas, os financiadores foram mantidos na ordem em que aparecem na fonte.
} 


\section{Anexo D: Ficha do Mural de Propostas}

Ficha a ser preenchida para divulgação de iniciativas no Mural de Propostas para a Construção de Outros Mundos do Fórum Social Mundial 2005.

Disponível em: www.forumsocialmundial.org.br/download/ficha_mural.rtf

FICHA PARA O MURAL DE PROPOSTAS DO FSM

Código da organização :

Código da atividade :

Nome do proponente/name of the person/nom de la personne :
1. Nome dado à proposta
Name of proposal
Nom de la proposition
2. Objetivo da proposta
Objective of proposal
But de la proposition
3. Ação para realizar esse objetivo
Action to reach the goal Action pour atteindre ce but
4. Qual organisação/quais organizaçoes propoem? - Which organizations are proposing it? - Organisations qui font la proposition

5. Em qual actividad do FSM a proposta foi presentada/discutada/acolhida - In which WSF activity was this proposal made/discussed/adopted - dans quelle activité du FSM cette proposition a-t-elle été présentée/discutée/approuvée ?

6 Âmbito da ação - frame of action - Niveau d'action

(local, regional, nacional, continental, mundial)

7. Uma ou duas palavras-chave One or two keywords Un ou deux mots-clés

8. Quais outras parcerias existirão, eventualmente

future possible partnerships partenariats prévus/possibles

10. contact - email

11. Observaciones - Observations - Observation 


\section{Anexo E: Números do FSM entre 2011 e 2005}

Fontes: www.forumsocialmundial.org e Secretaria do Grupo de Enlace do Conselho Internacional do Fórum Social Mundial, 2012

[2001]

- 20 mil participantes 4.700 delegados, de 117 países

- Atividades:

Conferências: 16

Oficinas, seminários e outras atividades organizadas pelos participantes: 420

Testemunhos: 22

\section{[2002]}

- 50.000 participantes, 12.274 delegados/as representando 123 países.

- Com os mesmos eixos temáticos do primeiro fórum, foram feitos 96 seminários, 27 conferências e 622 atividades autogestionadas.

\section{[2003]}

- 100 mil participantes. Cerca de 20 mil delegados/as, de um total de 123 países participaram do evento. A esse número devem ser acrescentados ainda os participantes do Acampamento da Juventude (cerca de 25 mil), jornalistas da mídia nacional e internacional (mais de 4.000) e participantes individuais que, em 2003, tiveram acesso à quase todas as atividades realizadas. - Atividades:

Conferências: 10

Oficinas, seminários e outras atividades organizadas pelos participantes: 1.286

Painéis: 36

Testemunhos: 22

Mesas de diálogo e controvérsia: 04

Expositores em atividades organizadas pelo Comitê Organizador: 292

Conferencistas de diversos países: 392.

\section{[2004]}

- 74.126 participantes, representados por 1653 organizações de 117 países. Do total, 60.224 eram indianos. No Acampamento Intercontinental da Juventude, foram registradas 2.723 inscrições.

- Uma novidade na metodologia do processo FSM foi a inclusão, no programa, de grandes atividades autogeridas pelas organizações inscritas no FSM, como painéis, conferências e mesas redondas. No total, foram organizados 35 eventos desse porte. Atividades autogeridas menores, como seminários, oficinas, reuniões, etc, tiveram presença marcante no FSM: houve 1.203 eventos.

\section{[2005]}

- 155 mil participantes cadastrados, sendo 35 mil integrantes do Acampamento da Juventude e 6.823 comunicadores.

- Cerca de 6.872 organizações de 151 países estiveram envolvidas em 2.500 atividades no Território Social Mundial 